University of Rhode Island

DigitalCommons@URI

Open Access Master's Theses

1987

\title{
Abundance and Catch Composition of Three Fishing Gears (Hook- and-Line Trap and Spear) in a Coral Reef. Santiago Island, Cape Bolinao, Philippines
}

Alejandro R. Acosta

University of Rhode Island

Follow this and additional works at: https://digitalcommons.uri.edu/theses

\section{Recommended Citation}

Acosta, Alejandro R., "Abundance and Catch Composition of Three Fishing Gears (Hook-and-Line Trap and Spear) in a Coral Reef. Santiago Island, Cape Bolinao, Philippines" (1987). Open Access Master's Theses. Paper 822.

https://digitalcommons.uri.edu/theses/822

This Thesis is brought to you for free and open access by DigitalCommons@URI. It has been accepted for inclusion in Open Access Master's Theses by an authorized administrator of DigitalCommons@URI. For more information, please contact digitalcommons-group@uri.edu. 
ABUNDANCE ANI) CATCH COMPOSITION OF THREE FISHING GEARS (HOOK-ANI)-LINE TRAP ANI) SPEAR) IN A CORAL REEF. SANTIAGO ISLANI), CAPE BOLINAO, PHILIPPINES.

BY

ALEJANIJRO R. ACOSTA

A THESIS SUBMITTEI IN PARTIAL FULFILLMENT OF THE REQUIREMENTS FOR THE DEGREE OF

MASTER OF SCIENCE

IN

FISHERIES, AQUACULTURE ANI) PATHOLOGY

UNIVERSITY OF RHODE ISLANI) 


\section{MASTER OF SCIENCE THESIS}

\section{OF}

ALEJANDRO R. ACOSTA

APPROVED :

Thesis Committee

Major Professor

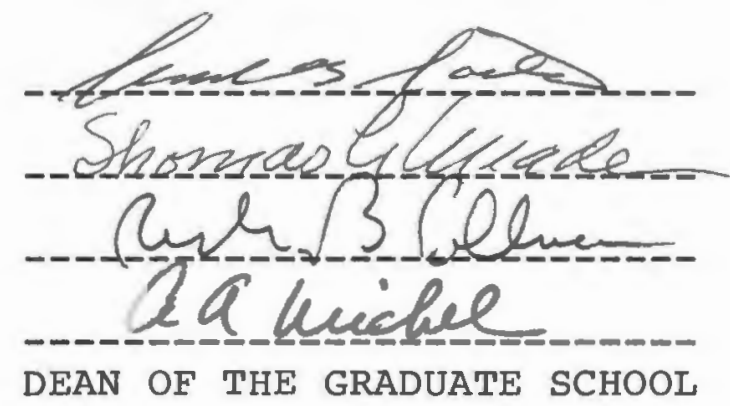




\section{ABSTRACT}

The catch rate and species composition of a multispecies reef fishery around Santiago Island, Cape Bolinao, Philippines, was studied from June to December 1986. Three fisheries were monitored, hook-and-line, spear and trap fishing. A total of 144 species were caught by the three gears. One hundred twenty-seven species were represented in the catches of the trap fishery. One hundred one were present inside the reef lagoon and 90 outside the reef lagoon. The family Siganidae contributed 42.28 of the total catch outside the lagoon and Family Labridae contributed 26.58 inside the lagoon. The hook-and-line fishing was dominated by lethrinids (69.8\%), specifically Lethrinus rodopterus. Spear fishing was dominated by siganus canaliculatus, contributing 83.78 of the total catch.

The catch rates for the trap fishery were 0.129 $\mathrm{kg} / \mathrm{haul}, 0.131 \mathrm{~kg} / \mathrm{haul}$ inside and $0.127 \mathrm{~kg} / \mathrm{haul}$ outside the reef lagoon. The catch rate for the hook-and-line and spear were $0.589 \mathrm{~kg} /$ line $\mathrm{hr}$. and $1.33 \mathrm{~kg} / \mathrm{man} \mathrm{hr}$ respectively. The size composition and the lengthweight relationships for the most abundant species of the three fisheries are discussed.

The fish yield of a reef area of $9.06 \mathrm{sq} . \mathrm{km}$ to the $15-\mathrm{m}$ isobath was $2.46 \mathrm{mt} / \mathrm{sq} \mathrm{km}$ during the rainy season. The annual fish yield was estimated to be around $4.17 \mathrm{mt} / \mathrm{sq} \mathrm{km} \mathrm{yr}$. 
I wish to express my gratitude to a number of people who have made this thesis possible. Thanks go to the United States Agency for International Development (USAID) for supporting this research through the (CRSP) program, and to the International Center for Marine Resource Development (ICMRD) for their support.

I am very grateful for the encouragement, assistance, and frindship provided by Ralph G. Turingan during all stages of this study. Thanks go to all the menbers of my committee, specially to Dr. Saul B. Saila for acting as my major professor and for his valuable comments. Special appreciation is extended to Karim Erzini whose reviews and insightfull comments helped me in editing this thesis, and to Dr. Conrad Recksiek for his invaluable advice and direction throughout my studies.

While I was in the Philippines, my work was eased considerably by the presence and aid of all the personnel of The Marine Science Institute of the University of the Philippines. I am also indebted to Dr. John McManus and Dr. Liana McManus for their contribution to the development of this project. Cleto Nonola is thanked for his valuable help in the data collection. Joy O. Escobar, Celeste Philibrick, and Anabell Del Norte deserve special acknowledgement. MY 
most sincere thanks go to the people of Bolinao, and to the fishermen of Silaki and Binabalian in Santiago Island.

Finally, I would like to express my thanks to my family and friends, specially to Lorena who gave me strength and encouragement during this time. 


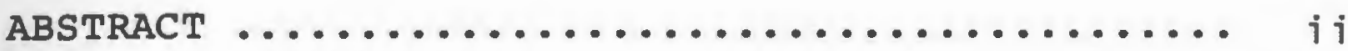

ACKNOWLEDGEMENTS $\ldots \ldots \ldots \ldots \ldots \ldots \ldots \ldots \ldots \ldots \ldots \ldots$ if

TABLE OF CONTENTS $\ldots \ldots \ldots \ldots \ldots \ldots \ldots \ldots \ldots \ldots$ v

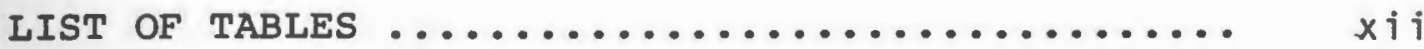

LIST OF FIGURES $\ldots \ldots \ldots \ldots \ldots \ldots \ldots \ldots \ldots \ldots \ldots \ldots \ldots \ldots \ldots$

I. INTRODUCTION $\ldots \ldots \ldots \ldots \ldots \ldots \ldots \ldots \ldots \ldots$

1.1 Background Fishing Gears .......... 12

II. MATERIALS AND METHOdS ............. 17

2.1 Description of the Study Area ...... 17

2.2 General Sampling Procedures ........ 21

2.3 Catch, effort and Catch Per Unit

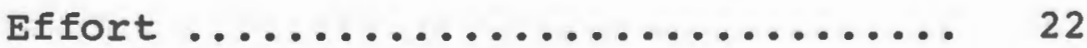

2.4 Compilation of Length Data ........ 24

2.5 Length-weight relationship ........ 25

2.6 Fish Yield .................. 25

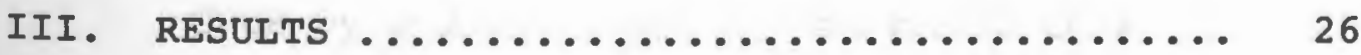

3.1 Description of the Trap Fishery ..... 26

3.2 Catch and Catch Per Unit Effort ..... 29

3.3 Catch Composition .............. 41

3.4 Notes on the Biology ........... 50

3.5 Description of the Hook-and-Iine 
Fishery $\ldots \ldots \ldots \ldots \ldots \ldots \ldots \ldots \ldots$

3.6 Catch, effort and Catch Per Unit

Effort $\ldots \ldots \ldots \ldots \ldots \ldots \ldots \ldots \ldots$

3.7 Catch Composition ............. 62

3.8 Notes on the Biology ........... 72

3.9 Description of the Spear Fishery .... 77

3.10 Catch, effort and Catch Per Unit

Effort $\ldots \ldots \ldots \ldots \ldots \ldots \ldots \ldots \ldots \ldots$

3.11 Catch Composition ............ 86

3.12 Notes on the Biology ........... 86

$3.13 \mathrm{Fish}$ Yield .................... 95

IV. DISCUSSION .................. 97

4.1 Catch, Effort and Catch Per Unit

Effort $\ldots \ldots \ldots \ldots \ldots \ldots \ldots \ldots \ldots$

4.2 Catch Composition .............. 101

4.3 Notes on the Biology ........... 107

4.4 Fish Yields ................. 111

v. CONCLUSIONS AND RECOMMENDATIONS ........ 113

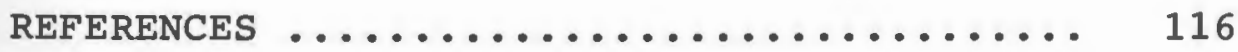

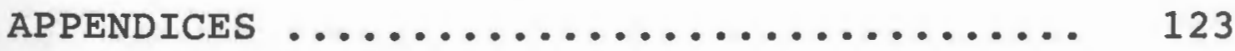

1. Summaries of Trap catches, effort and CPUE by sampling day in the outer edge of a coral reef lagoon. Cape Bolinao. June-December $1986 \ldots \ldots \ldots \ldots \ldots \ldots \ldots$

2. Summaries of Trap catches, effort and CPUE by sampling day in the outer edge of a coral reef lagoon. Cape Bolinao. 
June-December 1986

3. Contengency table of the four major families represented in the catches of traps inside and outside a fringing reef Cape Bolinao, Philippines ........

4. Species composition by number, weight and percentage of total trap catch inside of a coral reef lagoon Cape Bolinao, Philippines ...........

5. Species composition by number, weight and percentage of total trap catch inside a coral reef lagoon Cape

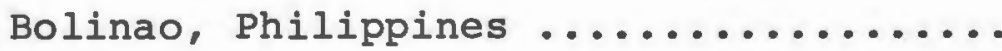

$6 \mathrm{~A}$. Length-frequency distribution of Siganus spinus by location and comparison between locations .........

6B. Length-frequency distribution of Siganus canaliculatus by location and comparison between locations

6C. Length-frequency distribution of Scarus rhoduropterus by location and comparison between locations .........

6D. Length-frequency distribution of Labrid $A$ by location and comparison between locations

6E. Length- Frequency distribution of Stagastes sp. by location and 
comparison between locations .........

6F. Length-frequency distribution of

Cheilinus trilobatus by location and

comparison between locations .........

6G. Length-frequency distribution of

Epinephalus merra by location and

comparison between locations .........

$6 \mathrm{H}$. Length-frequency distribution of

Apogon sp. by location and comparison

between locations ................

7A. Length-weight relationship for Siganus

spinus.$\ldots \ldots \ldots \ldots \ldots \ldots \ldots \ldots \ldots$

7B. Length-weight relationship for Siganus canaliculatus

7C. Length-weight relationship for Scarus rhoduropterus $\ldots \ldots \ldots \ldots \ldots \ldots \ldots \ldots$

7D. Length-weight relationship for Labrid

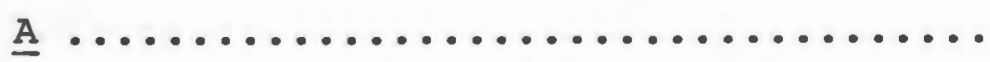

$7 E$. Length-weight relationship for

Stagastes sp.

7F. Length-weight relationship for

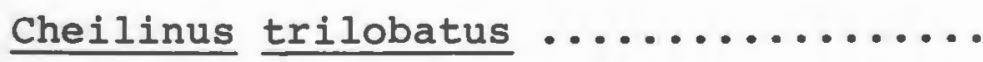

$7 G$. Length-weight relationship for

Epinephalus merra

7H. Length-weight relationship for Apogon sp. $\ldots \ldots \ldots \ldots \ldots \ldots \ldots \ldots \ldots \ldots$

8. Species composition by number, weight 
and percentage of total catch for hook-and-line fishery Cape Bolinao,

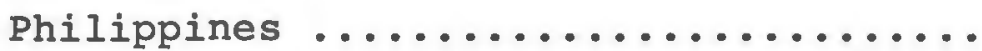

9A. Length-frequency distribution for

Lethrinus rhodopterus caught by

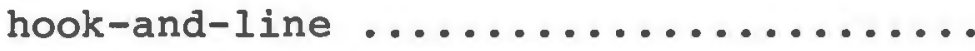

9B. Length-frequency distribution for

Lethrinus variegatus caught by

hook-and-line

9C. Length-frequency distribution for

Lethrinus ornatus caught by

hook-and-line

9D. Length-frequency distribution for

Lutjanus fulviflamma caught by

hook-and-line

9E. Length-frequency distribution for

Lutjanus gibbus caught by

hook-and-line

10A. Length-weight relationship for

Lethrinus rhodopterus caught by

hook-and-line

10B. Length-weight relationship for

Lethrinus variegatus caught by

hook-and-line $\ldots \ldots \ldots \ldots \ldots \ldots \ldots \ldots$

10C. Length-weight relationship for

Lethrinus ornatus caught by

hook-and-line 
10D. Length-weight relationship for

Lutjanus fulviflamma caught by

hook-and-line $\ldots \ldots \ldots \ldots \ldots \ldots \ldots$

10E. Length-weight relationship for

Lutjanus gibbus caught by

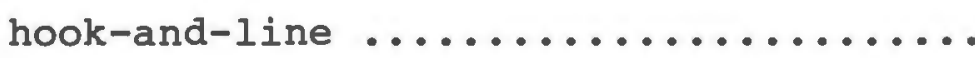

11. Species composition by number, weight and percentage of total catch for the Spear fishery Cape Bolinao,

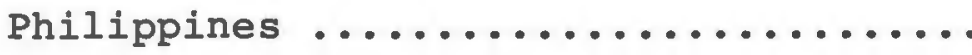

12A. Length-frequency distribution for

Siganus guttatus caught by spear.....

12B. Length-frequency distribution for

Gnatholepis puntang caught by spear.....

12C. Length-frequency distribution for

Mulloidichthys falvolineatus caught by spear

13A. Length-weight relationship for

Siganus guttatus caught by spear......

13B. Length-weight relationship for

Gnatholepis puntang caught by spear.....

13C. Length-weight relationship for

Mulloidichthys falvolineatus caught by spear

14. Monthly length-frequency distribution

for Siganus canaliculatus caught by

spear June-December 1986 
15A. Length-weight relationship for Siganus canaliculatus caught by spear, June 1986

15B. Length-weight relationship for

Siganus canaliculatus caught by spear, July 1986

15C. Length-weight relationship for

Siganus canaliculatus caught by spear, August 1986

15D. Length-weight relationship for

Siganus canaliculatus caught by spear,

September 1986

$15 \mathrm{E}$. Length-weight relationship for Siganus canaliculatus caught by spear, October 1986

15F. Length-weight relationship for Siganus canaliculatus caught by spear, November $1986 \ldots \ldots \ldots \ldots \ldots \ldots \ldots$

15G. Length-weight relationship for Siganus canaliculatus caught by spear,

December 1986

15H. Length-weight relationship for Siganus canaliculatus caught by spear, June-Dec 1986 
Table

1. Total weight and number of fish produced by the trap fishery. Cape Bolinao,

Philippines. June- December 1986 ........

2. Summary of monthly trap catches. Cape

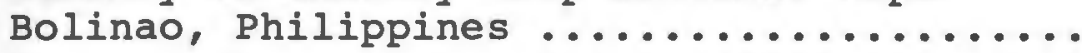

3. Summary of the monthly trap catches in the outer edge of a coral reef lagoon. Cape

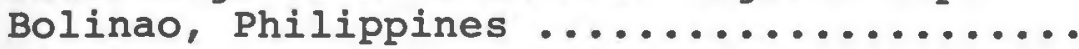

4. Summary of the monthly trap catches inside a coral reef lagoon. Cape Bolinao,

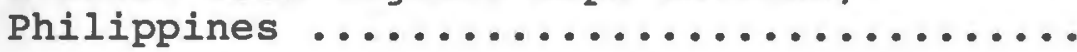

5. Summary of the major families represented in trap catches. Cape Bolinao, Philippines.

6. Major families represented in catches of traps in the outer edge of a coral reef lagoon. Cape bolinao. Philippines ........

7. Major families represented in trap catches inside a coral reef lagoon. Cape Bolinao,

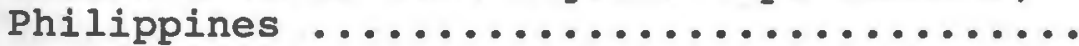

8. Relationship of total length (TL) to standard length (SL) and standard length to total length for eight species from the trap fishery inside and outside a fringing reef. Cape Bolinao, Philippines ..........

9. Relationship of total length (TL) to weight (W) for eight species from the trap fishery. June-Dec $1986 \ldots \ldots \ldots \ldots \ldots \ldots \ldots$

10. Summary of monthly lines catches in the outer edge reef. Cape Bolinao, Philippines. June-Dec 1986

11. Species comprising more than 18 of the weight and number caught for the hook-and-line fishery. Cape Bolinao, Philippines. June-Dec 1986 ............

12. Monthly percent of the three most abundant families for the hook-and-line fishery. Cape Bolinao, Philippines June-Dec 1986 ... 
13. Relationship of total length (TL) to standard length (SL) and standard length to total length for five species from the hook-and-line fishery. Cape Bolinao,

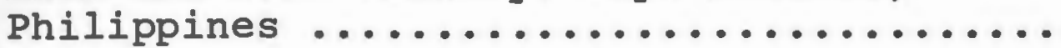

14. Relationship of total length (TL) to weight (W) for five species from the hook-and-line fishery. Cape Bolinao,

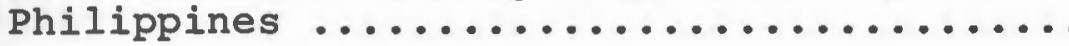

15. Summary of monthly spear catches in a coral reef lagoon. Cape Bolinao, Philippines. June-Dec 1986

16. Major families represented in Spear catches in a coral reef lagoon. Cape Bolinao, Philippines .................

17. Species comprising more than 18 of the weight and number caught for the spear fishery. Cape Bolinao, Philippines. June-Dec $1986 \ldots \ldots \ldots \ldots \ldots \ldots \ldots \ldots \ldots \ldots \ldots$

18. Relationship of total length (TL) to standard length (SL) and standard length to total length for four species from the spear fishery. Cape Bolinao. Philippines ..

19. Relationship of total length (TL) to weight (W) for four species from the spear fishery. Cape Bolinao, Philippines 
Figure

1. Study and sampling area. Northern part of Santiago Island. The triangular area was the area considered for the fish yield estimation. the shadow areas are the fishing

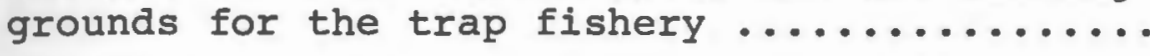

2. Detail description of a the fish trap used to catch coral reef fishes in Cape Bolinao, Philippines

3. Picture showing a fish trap in the water.....

4. Picture of a typical bamboo raft used for navigation and fishing operations by trap fishermen around Cape Bolinao, Philippines...

5. Picture of a trap cover with coral in order to simulated a coral head ................

6. Relationship between catch and total effort for the trap fishery. The months are represented by the letters: $J=$ June, $J=$ July, $A=$ August,$S=$ September, $0=$ October, $\mathrm{N}=$ November, $\mathrm{D}=$ December $\ldots . . . .$.

7. Relationship between CPUE and total effort for the trap fishery. The months are represented by the letters: $\mathrm{J}=$ June, $\mathrm{J}=$ July, $A=$ August,$\quad s=$ september, $0=$ October, $\mathrm{N}=$ November, $\mathrm{D}=$ December $\ldots . . . .$.

8. Monthly CPUE for the four most abundant families represented in the trap fishery. (Siganidae, Labridae, Scaridae, and Serranidae)

9. Summary of the monthly trap catch total and by location. June-Dec $1986 \ldots \ldots \ldots . . . . . .$.

10. Summary of the monthly number of traps, total and by location. Cape Bolinao June-Dec 1986

11. Iiner regression between total catch and total effort for the trap fishery. Cape Bolinao. June-Dec 1986

12. Summary of the monthly CPUE for the trap 
fishery, total and by location. June-Dec

1986

13. Summary of the monthly number of fishes caught by the trap fishery, total and by location. June-Dec 1986 ...............

14. Ninety five percent confidence intervals for the slope values from the length-weight relationship of eight species from the

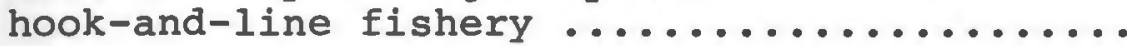

15. Fishing gear used for the hook-and-line fishery in Cape Bolinao. Philippines .......

16. Hand made fishing hooks from stainless steel.

17. Traditional non-motorized banca used for the hook- and-line fishermen in Cape Bolinao ....

18. Monthly CPUE for the Hook-and-line fishery. Cape Bolinao, Philippines. June-Dec 1986 ....

19. Monthly catch from the hook-and-line fishery. Cape Bolinao, Philippines. June-Dec 1986

20. Monthly total catch estimates for the hook-and-line fishery. Cape Bolinao, Philippines. June-Dec 1986

21. Relationship between Catch and Effort for the hook- and-line fishery. The months are represented by the letters: $\mathrm{J}=$ June, $\mathrm{J}=$ July, $A=$ August,$S=$ September, $0=$ October, $\mathrm{N}=$ November and $\mathrm{D}=$ December $\ldots . .$.

22. Relationship between CPUE and Effort for the hook- and-line fishery. The months are represented by the letters: $\mathrm{J}=$ June, $\mathrm{J}=$ July, $\mathbf{A}=$ August, $\mathbf{S}=$ September, $0=$ October, $\mathbf{N}=$ November and $\mathrm{D}=$ December $\ldots . .$.

23. Linear regression between total catch and total effort for the hook-and-line fishery.

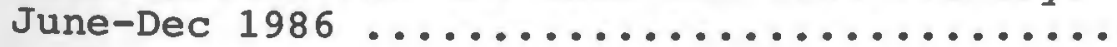

24. Monthly number of fishes caught by the hook and-line fishery. Cape Bolinao, Philippines. June-December 1986

25. Monthly cPUE for the three major families caught by the hook-and-line fishery

(Lethrinidae, Lutjanidae, Serranidae). June- 
26. Fishing lamp used in the spear fishery with a modified gas tank and stainless steel lamp

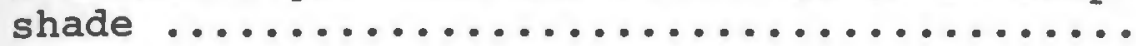

27. Fishing gear used for the spear fishermen, wooden goggles spear gun and wooden flippers..

28. Monthly CPUE for the spear fishery. Cape Bolinao, Philippines. June-December 1986 ....

29. Monthly catch from the sampling of the spear fishery. Cape Bolinao, Philippines. June-December $1986 \ldots \ldots \ldots \ldots \ldots \ldots \ldots \ldots \ldots$

30. Monthly total estimates for the spear fishery. Cape Bolinao, Philippines. June-December 1986 ..................

31. Monthly number of fish caught for the spear fishery. June-December $1986 \ldots \ldots \ldots \ldots \ldots$

32. Relationship between total catch and total effort for the spear fishery. June-December

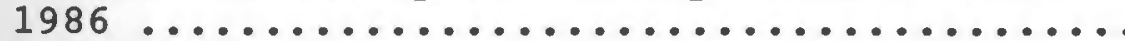

33. Relationship between CPUE and total effort for the spear fishery. June-December 1986...

34. Linear regression between fishing effort and total effort for the spear fishery. June-December $1986 \ldots \ldots \ldots \ldots \ldots \ldots \ldots \ldots \ldots \ldots$

35. Ninety-five percent confidence intervals on slope (b) values from the monthly length-weight relationship for siganus canaliculatus caught for the spear fishery. June-December $1986 \ldots \ldots \ldots \ldots \ldots \ldots \ldots \ldots \ldots$

36. Monthly catches for hook-and-line, trap and spear in Cape Bolinao. June-December 1986....

37. Monthly CPUE for hook-and-line and spear in Cape Bolinao. June-December 1986 
The Philippines is an archipelago composed of more than 7000 islands. It's coast line stretches approximately $34,417 \mathrm{~km}$ and is bordered by $27,000 \mathrm{~km}$ of coral reef surface. This unique geographical feature gives the Philippine people a strong orientation toward the sea and fishing. The significance of the reef ecosystem to the Filipinos is it's productivity. Seafood is a source of relatively cheap protein food and livelihood in coastal communities (Bolanos and Alino, 1984). While about $60 \%$ of the total fisheries catch is obtained from the coastal waters in general (Gomez et.al,1981), at least 10 to $15 \%$ of fish production is associated with coral reefs (Carpenter, 1977).

Smith (1978) calculated that coral reefs and associated communities of depths of less than $30 \mathrm{~m}$ cover about $600,000 \mathrm{~km}^{\wedge} 2$ on a global basis. $30 \%$ of these communities are found in the area bounded by Indonesia to the west, Northern Australia to the south, the Philippines to the east, and mainland Asia to the North. $30 \%$ is in the Indian Ocean, Arabic Gulf and Red Sea, $13 \%$ in the South Pacific, 128 in the North Pacific, 148 in the Caribbean and North Atlantic, and $1 \%$ in the South Atlantic. The most heavily exploited areas are believed to be in parts of the Caribbean and the Philippines, and localized in areas close to major urban centers throughout the tropics (Munro and 
Williams, 1985).

Coral reefs, seagrass beds and mangrove swamps form a widespread, highly productive complex of shallow marine communities in the tropics. The total production of fish in these communities has never been calculated but it is undoubtably substantial (Johannes, 1980). In tropical regions, coral reefs have one of the highest fish yields. They may rank second to estuaries and ponds in fish productivity, having a range of 0.09 to 20 tons/ sq km/yr (Marten and Polovina, 1982). Sea-grass beds are often interposed between intertidal mangrove communities and offshore coral reefs. No measurements of fish production are available for sea-grass beds but it is known that primary production is exceptionally high (Odum et al. 1973; Zieman, 1975). Where these communities occur together, their faunas overlap considerably (Olsen et al. 1973). Many species of fish which spend their adult lives in the reef, live as juveniles in the adjacent seagrass beds or mangrove swamps. Many species venture out on the seagrass beds to feed at night, returning to the safety of the reef during the day (Austin, 1971; Munro, 1974). Harvesting of these communities involves working over a wide variety of substrate and bottom contours. Thus, no single method generally accounts for the bulk of the harvest. Most coral reef fisheries are based upon the use of three fishing gears: a) hook-and-line, b) fish 
traps, and c) gillnets (Munro and Williams, 1985). Other fishing gears such as spear guns, seine nets, and a variety of other devices are used in specific fisheries.

Size selection and species selection differ with each fishing method. Hook-and-line is usually used to catch predatory fishes and it is highly selective in terms of the species captured. On the other hand, traps are rather unselective and catch a very wide range of species. Spear guns are mainly used to catch a preferred species and are therefore very selective. The variety of methods of fishing used in the Philippines to catch coral reef fishes vary from the illegal fishing with explosives and fish poison, to the commercial muro-ami (Japanese drive-in-net). Traps, hook-and-line and spear guns are some of the most popular methods used by coastal fishermen to harvest coral reef fishes around Santiago island. While statistics do not exist for the exact volume caught or landed by these three gears in the country, it is clear that these gears are being used by many fishermen in the coral reef areas all through the country. Librero, Ramos and Lapie (1982) conducted a survey in eight regions of the Philippines and found that 24 percent of the fishermen surveyed used lines for fishing and 4 percent used hand instruments (mostly spear guns) and traps. 
Many of the standard techniques for sampling fish populations can only be used with great difficulty in reef environments (Sale, 1982). The choice of a suitable method is in large determined by the type of reef, the limitations and biases of the gear, and the constraints confronted by the investigator, such as time and manpower. Russell et al. (1978) listed the techniques commonly used in the collection of coral reef fishes. They described a number of methods widely used in stock assessment, and noted the advantages and disadvantages of each method. Among the methods used were fish traps, handlines, handspears, Hawaiian slings, spear guns, gillnets, and others. These methods are highly selective in terms of size or species, and are usually suitable only for certain reef types or topographies (Sale, 1982; Gomez, 1981). This is not to imply that traditional methods have not been used in the study of reef ecology. Munro (1976), Munro et al. (1973), and Thompson and Munro, (1974b) have used fish traps to produce highly creditable examples of catch composition and fish yields using "traditional" approaches (Sale, 1982). Relatively good assessments of fish abundance and species compositon can be obtained by combining visual census techniques and a number of capture techniques. However, as most tropical seas are bound by developing countries with relatively low levels of industralisation, the availability of scuba 
gear and trained personal can be limited. In addition, the diver (the researcher) needs to be trained to identify and estimate sizes of fish underwater.

over the years, conflicting opinions have emerged concerning the productive potential of coral reef fisheries, mostly as a result of different perceptions of what constitutes a desirable harvest, what fish and invertebrates are to be included in the definition of "coral reef fishes", and about the trophic ecology of the coral reef community and the reproductive processess (Munro and Williams, 1985). Marten and Polovina (1982) found that fish yields from coral reefs were similar to those for other continental shelf fisheries despite the higher primary productivity of coral reefs. Stevenson and Marshall (1974) attempted a generalization as to the fisheries potential of coral reef and adjacent shallows, and suggested that coralline shelves with good cover of actively growing coral reef, seagrass beds, and algae usually produced around 4 to $5 \mathrm{mt} / \mathrm{km}^{\wedge} 2 /$ year.

More recently, Alcala (1981), Alcala and Luchavez (1982), Marriott (1984), and Wass (1982) reported estimates ranging from 15 to 27 Tons/Km²/Yr. It seems that conflicting reports on yield from coral reefs have resulted from comparison of areas with greatly different mean depths and physiographic features of the coral reef environments (Alcala and Gomez, 1985; Munro 
and Willians, 1985). Reef fishing is generally done in a patch of coral reef (which is highly productive) and in sandy bottoms (which are not so productive). The yield per unit area that is calculated for a reef depends very much upon the size of the area and the percentage of that area which is actually covered by coral or other hard substrate (Marten and Polovina, 1982). Saila and Roedel (1980) recommended that research to develop methods for rapid assessment of stock based on enviromental indices be initiated. For example, a morpho-edaphic index could be developed for coral areas in which the index was based upon the relative proportions of different habitats on the shelf (Munro and Williams, 1985). A habitat approach emphasizes attention to species composition (including a classification of fish communities), how different fish communities are associated with different habitats, and how community composition responds to human activities (including fishing) which impinge upon the fishery (Smith et al. 1973; Marten, 1981; Marten and Polovina, 1982). This perspective does not mean that massive amounts of quantitative data are required in more detail than before, but that the data must be sensitive to species composition.

Although the production of multispecies fishery can be manipulated to some extent by adjusting the harvesting regime, the yield from the fishery can be 
reduced immensely by habitat destruction (Gomez et al. 1981; Marten and Polovina, 1982; Munro and Williams, 1985). Destructive fishing practices such as dynamiting, poisoning, seining and trawling disrupt the production of fish food or spawning of fish. Another factor is habitat destruct) on originated by non-fishing activities such as mining, siltation due to run-off, oil drilling and pollution from urban centers (Carpenter and Alcala, 1977; Alcala and Gomez, 1979; Corpuz and Alino, 1983; Hudson et al. 1982; Marten and Polovina, 1982; Bolanos and Alino, 1984).

The fish yield from an ecosystem cannot be inferred from records without reference to the fishing effort behind those records (Marten and Polovina, 1982). Fishing effort is very important for yield estimates, because such estimates are generally obtained by multiplyng catch per unit effort (from sampling data) by the total effort in the fishery (Munro, 1978; Gulland, 1979; Marten and Polovina, 1982). Determining the fishing effort of coral reef fisheries can be extremely difficult because of the large number of fishermen involved and the different users of the resource. The yield from a multispecies fisheries is not only a matter of how much fishing, but also, what kind of fishing. Marten (1979a, 1979b) summarized the impact upon the stocks in Lake Victoria due to the amount of fishing and the kind of fishing. He showed 
that above a certain fishing effort, the total multispecies catch is not affected much by fishing effort per se, but by the kind of gear employed. He also indicated that there was not a gear mix which is optimal for all species in the fishery. What is optimal for one species may under- exploit or destructively exploit another species. Fishing gear also has indirect ecological effects upon fish species that may not even be captured by that kind of gear because of predation and competition, and these effects may lead to successional changes in the species composition and age composition of the fishery (Marten, 1979a; Craik, 1982; Marten and Polovina, 1982; Munro and Williams, 1985).

Although heavy fishing may not in itself significantly reduce the total yield from a multispecies fishery, it is quite common for heavy fishing or the wrong kind of gear to change the species composition, and therefore economic value, of the fishery. Koslow et al. (1986) compared the trap fish catches between the periods 1969-73 and 1986 in three areas with varying degrees of fisheries exploitation in Jamaica. They found that the overall catches declined significantly in areas in which the effort had more than doubled during the 17 year period, but catch was unchanged in areas with lower levels of effort. They also found a change in the species composition and size composition in areas of heavy effort. Russ 
compared the abundance of preferred target species on the reef slope of Sumilon island (protected from any fishing) to Apo and Balicasag island (open to fishing) in the Philippines. He found significantly more of the highly preferred species, including a significantly higher biomass of serranids (groupers) within the protected site than in the others. Russ concluded that the protective management had been very important in maintaining high abundances of many species, but the difference between sites could not be attributed only to the protective management. He suggested that sumilon island was perhaps a naturally richer site than the others before its protection.

The use of complex models of multispecies temperate water fisheries in tropical multispecies fishery would involve the estimation of thousands of parameters (Larkin and Gazey, 1982). Kirkwood (1982) reviewed attempts to develop multispecies versions of the Schaefer model and of the generalized production models and concluded that there was insufficient understanding of the underlying biological processes and that the unavailability of estimates of the model parameters resulted in even the simplest models having "little to offer at the present in the way of management paradigms for tropical multispecies fisheries". Munro (1980) and Sainsbury (1982) reached the same conclusions.

Multispecies fisheries management and yield 
assessment will have to use a more empirical approach, based on observations of how fish community composition and yields change under different circumstances, taking advantage of the work done in different places and with different fishing effort and fishing conditions (Munro, 1980; Marten and Polovina, 1982; Kirkwood, 1982; Sainsbury, 1982; Munro and Williams, 1985).

So far, the studies conducted in coral reef areas have focused mainly on the estimation of fish yield rather than on both the fish yield and species composition (Marten and Polovina, 1982). Most of the experimental studies in reef areas involve small species and are carried out within localized areas (Sale, 1982; Munro and Williams, 1985). The accuracy with which the results of these studies can be expanded into general statements varies with the sophistication of the experimental designs (Munro and Williams, 1985). Marshall (1980) suggested that in order to improve fish yield estimates, better and additional catch observations, plus more experimental fishing such as Munro (1978a), and more recently koslow et al. (1986) undertook in Jamaica, would be very useful. There is also a need to clarify the gathering and reporting of catch data in order to eliminate the bias with respect to what catches are made; what areas are fished, and what environments are involved (Williams, 1977; Marshall, 1980; Miller, 1986). 
Santiago Island in Cape Bolinao, Philippines has a variety of marine biotopes: a fringing reef system, extensive reef flats and lagoons, patch reefs, and seagrass beds. Santiago Island reef and lagoon have recently been the subject of an extensive baseline ecological survey. A component part of this survey was a study of the abundance and catch composition of the three major fishing gears used in the reef and in the reef lagoon. The present study provides baseline data for future studies of temporal and geographical variation. It also sets the basis for a data collection system to monitor changes in fishing effort and its effect on the species composition. Estimates of abundance are given and an attempt was made to relate observations to ecological factors.

The main objectives of this study were:

a) To describe the trap, spear and hook-and-line fisheries at Santiago Island.

b) To determine the abundance of each species caught by the three gears and to determine the catch per unit effort for each of the gears.

c) To determine the catch composition of hook-and-line, spear guns and fish traps in a coral reef system,

d) To contribute information to the biology of the most abundant species caught by the three gears in terms of size composition and length-weight relationships. Additionally, the relationship between total length 
(TL) and standard length (SL) was calculated for the most abundant species.

e) To estimate the fish yields for the study area. (1.1) Background Fishing gears

Munro and Williams (1985) stated that the main problem in terms of fishing gear in coral reef fisheries is the lack of knowledge of the selective characteristics of the gear. Some studies have been conducted on the construction, description, and operation of fishing gear in coral reefs but few of them deal with the selectivity factor of the gear. Carpenter and Alcala (1977) observed muro-ami operations using SCUBA, and found that the gear was highly selective as most of the bottom fishes (demersal) ignored the scareline and only those nearest to the net were caught. Corpuz, Castaneda and Sy (1983) agreed with this observation.

Fish traps of varius shapes, sizes and styles are used in many localities but especially around coral reefs. There is a certain amount of geographic variation in their construction, largely reflecting local availability of the materials used. Traps are the principal commercial gear in most Caribbean reef fisheries and in most crab and lobster fisheries worldwide (Munro, 1974a; Miller, 1986). The fundamental concept is the same in most areas. The fish enter the trap via one or several entrance funnels, generally 
designed for easy entry and difficult escape. Munro et al. (1971) and Munro (1974) studied the dynamics of Antillian fish traps. These investigators determined that the catch leveled off asymptotically after some optimum soak time. They postulated that fish continued to enter the trap at a fairly constant rate, and that daily escapement was a fixed proportion of the number of fish in the trap. Trap catch attained its maximum level when the ingress of fish equaled escapement.

Fish traps are used over a wide depth range, being set in different depths to target different species assemblages. Common features of the trap fishery are the highly variable catch rates and species composition. This is probably due in part to the complex set of behavioral attributes exhibited by the reef species taken in traps and to the location of the traps in relation to the reef (Luckhurst and Ward, 1986). Trap location relative to bottom irregularities (e.g. ledges, coral heads, rock piles) may be critical; distances as little as five feet from reef biotopes have shown surprising differences in catch rates of tropical, coral reef associated species (Sylvester and Damman, 1972). However, some reports suggest that the relationship of trap location to catch composition varied geographically by species, and by depth (Boardman and Weiler, 1980).

Fish traps may or may not be baited. High and Ellis 
(1973) suggested that there was little difference in catch rate between baited and unbaited traps. Baited traps were more effective in catching fish than unbaited traps during short periods $(<24$ hours) in inshore environments in the South Atlantic Bight (Powles and Barans, 1980). High and Beardsley (1970) contended that fish enter the traps for reasons other than the bait. Random movements, use of traps as shelter, curiosity, intrapecicific social behavior, and predator escapement are probably very important factors in trap catches.

Munro (1983) assumed that the minimum size retained for a given species is a function of the mesh size and the maximum body depth of the species. Hartsuijker and Nicholson (1981); Luckhurst and Ward (1986) suggested that recruiment to the trap fishery may be more a function of behavioral changes with size than the mesh size used. Munro et al. (1971) suggested that conspecific attraction in increasing the ingress rates of a species was important. Luckhurst and ward (1986) suggested that conspecific attraction was a major factor affecting the species composition and abundance of fish in traps. Catch rates undoubtedly vary according to moon phase and corresponding tidal pattern. Craig (1976) and Luckhurst and Ward (1986) observed that greatest catches were usually associated with rough sea conditions. 
It is commonly believed that traps are highly unselective and that many species of noncommercial interest are consequently wasted. Trap fishing allows the capture of a large number of species, but the bulk of the catch is composed mainly of a few species. Munro (1979b) reported that nine species of fish and spiny lobster made up about 50 percent (by weight) of the trap catches in the Port Royal area (Jamaica). The remainder was divided among another 100 species. Olsen et al. (1975) reported that of 1,559 fishes caught in West Indian traps, two species of snapper together with one species of grunt accounted for 90 percent by number. All of this evidence suggests that traps are generally quite selective (Craig, 1976; Boardman and Weiler, 1980). Thompson and Munro $(1974 a, c)$ showed that the length- frequency distributions of fish from trap catches do not differ significantly from those from hook-and-line catches.

Trap fishing is a convenient method for surveying fish density for the same reason that they are convenient for fishing. Traps can be used on almost any bottom, at any time and especially because the fish are usually alive when it arrives at the port. There are some difficulties in using traps as sampling devices. Miller (1986) reviewed a series of reports in which traps were used as sampling tools to estimate animal density and he concluded that catch per trap if often 
an unreliable index of abundance of the target species due to the large number of factors influencing trap catches. He suggested that when possible many relevant factors such as temperature, molt cycle, moon phase, trap design, bait and soak time should be standarized if trap catches are to be used as indexes of abundance. Due to the many unknown factors affecting trap catchability, even the most careful survey design using traps may provide only a gross index of the animal abundance.

Another important method employed in catching coral reef fishes is the ordinary handline or hook-and-line with single or multiple hooks. The specifications of this gear are many and varied, depending primarily upon the ideas and traditions of the fishermen. The basic technique of placing bait upon a hook and putting it into the water is commonplace but the expertise in controlling the baited line and sensing the fish tends more towards an art when demonstrated by experienced line-fishermen (Munro, 1983). Kawaguchi (1974) reported that experienced line-fishermen usually catch an average of 508 more than less experienced fishermen. The success of the fishing operation depends largely on the fisherman's ability to locate the fishing ground, based on his knowledge of the preferred habitat and the movements of the different fish species.

The fishing power in hook-and-line fishing is 
mostly governed by the number of hooks operated during a fishing operation. Many of the same factors which affect trap fishing also affect hook-and-line fishing. A number of studies have reported substantial bias in length-frequency samples derived from angling (Ralston, 1982). Fry (1949); Frazer (1955) concluded that size selection by hook-and-line is relatively severe and strongly dependent upon the size-classes sampled. Other researchers have come to different conclusions. Ralston (1982) concluded that for medium-and-large size fish, the catch is reasonably representative of those fish which strike the hooks and that a sigmoid selection curve most accurately described the selective properties of the gear.

Munro (1983) indicated that spearfishing was becoming an increasingly important economic activity in the Caribbean as a result of socioeconomic factors related to underemployment and to low capital investment required for participation. But this is not always the case, around Santiago island spear fishing is one of the most prosperous and competitive fisheries. It requires a high initial investment which is close to $\mathrm{P} 800$ (approximate $40 \mathrm{U.S.}$ dollars). In terms of selectivity, spearfishing tends to harvest the oldest and largest members of the community. II. Materials and Methods

(2.1) Description of the Study area 
The area chosen for this study was the northern part of Santiago Island, Cape Bolinao, on the west side of the Lingayen Gulf, Pangasinan, Philippines (see Fig 1). The northern part of Santiago Island is surrounded by a shallow lagoon. The lagoon depth varies from 3 to 15 feet. There are two channels connecting the sea with the lagoon. One is located at the western and the other is located in the northern part. These channels serve as passageways for water movements during tide changes. Sea water circulation in the lagoon is via these channels and by wave and tidal transport over the reef. Silaki Island is the largest land mass in the lagoon. Silaki is a semi-desert island with small bushes and small trees and a total area of around 0.02 sq. Km. The study area is affected by strong winds from the northeast and southwest, especially during monsoon seasons. The following is a brief description of the different biotopes, based on personal observations and information available on the flora and fauna of the study area.

\section{Outside reef}

The combined lower reef margin and reef crest were grouped as one biotope in order to compare the diversities of fish communities inside and outside the lagoon. A similar approach was taken by Jones and Chase (1975). This zone is distinguished by a framework of dead and living Acropora. The most abundant corals 


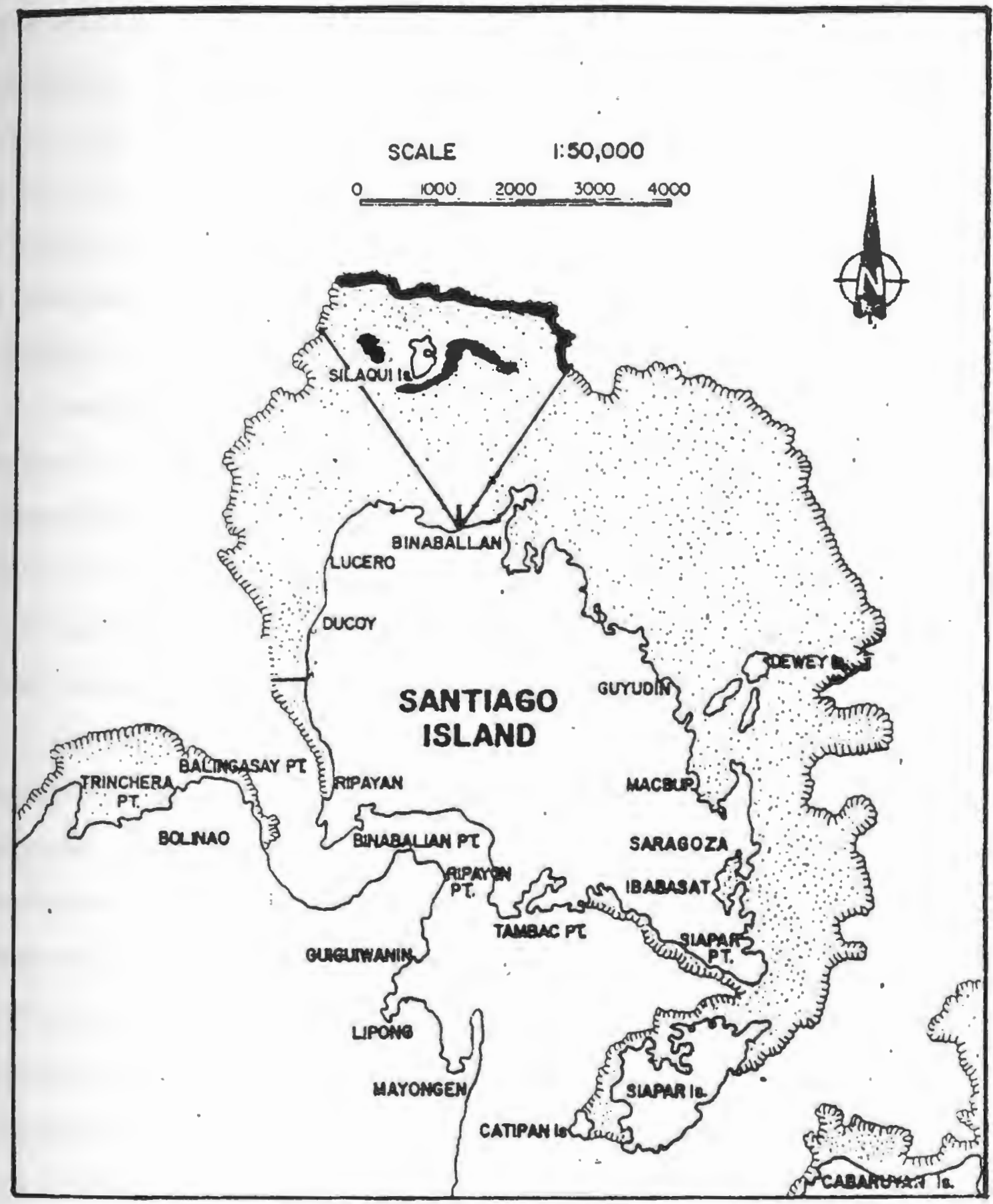

FIGURE 1

Study and Sampling area. Northern part of Santiago Island. The triangular area was the area considered for the fish yield estimation. The shadow areas are. the fishing grounds for the trap fishery. 
especially along the reef crest and the flat were Acropora and Montipora, while Millepora and Porites were the most common along the gentle reef slope (MSI,.Annual Rept, 1986). The bottom consists mainly of rubble and rock pavement covered by coralline algae along with patches of sand.

Lagoon Environment

Seagrass beds are recognized as important nursery areas for many important commercial and forage organisms, as well as for some of the reef species. The nursery role of the seagrass beds is due mainly to the availability of shelter for juvenile organisms and to the abundant supply of organic detrital food.

Fortes (1984) described the distribution and abundance of seagrasses at Bolinao. He found relatively diverse seagrass communities, formed by nine species of seagrasses. Species diversity was higher in relatively sheltered, undisturbed, moderately wave-exposed shore portions, with depths averaging between 1 to 15 feet. Enhalus acoroides, Thalassia hemprichii, and Cymodocea rotundata accounted for the highest percent of occurrence. Fortes (1984) concluded that the dominance of these three larger species indicated that the seagrass communities at Bolinao were at or near the climax stage in the successional process.

Patch reef

These lagoon reefs occurs all over the lagoon and 
at nearly all depths. Favorable substrate conditions together with wind and tide effects probably promoted the development of these structures which exhibit and attract a diverse reef fauna. The patch reefs are surrounded by sand and seagrass beds. They serve as shelter for fish.

\section{Sand bottom}

These are virtually featureless habitats offering no cover for fish except for burrowing species. The sand is very fine, but coarse material composed of corals, shells of mollusks and other organisms are scattered throughout the area.

\section{(2.2) General Sampling Procedure}

The data used in this study were collected from the catches of commercial trap, hook-and-line, and spear fisheries from Cape Bolinao, Philippines, from June to December 1986. Various survey techniques were used. Estimates of the number of fishermen, vessels and number of gear used for the three fisheries were determined by interviews and censuses. Fishermen, middlemen, as well as local and municipal officials were interviewed in order to determine seasonal trends in fishing effort and catch composition for each gear. A record keeping system was developed for use between the fishermen and middlemen. Fishermen and middlemen were chosen based on their willihgness to participate rather than randomly. The services of an interpreter la 
fellow researcher) who spoke Tagalog and Ilocano were used during the sampling period.

Fishermen were accompanied to the fishing grounds in order to observe fishing operations, to obtain individual data for each gear, and to train the fishermen in the collection of data. After several fishing trips with them, note-books were given to the fishermen and middlemen for the collection of catch and effort data for each gear.

Field data was recorded for every gear. The sampled data was normally collected from the fishing grounds. When this was not possible, it was collected when the catch was landed. To avoid biases, only data from single fishermen and data where the source was known, was used. Fish species were identified and samples were counted, individually weighed and measured to the nearest centimeter (cm). The number of gear deployed, soak time, fishing time, depth, bottom type, bait and fishing area were recorded for each gear. The number of fishermen per boat, number of boats out per night and all other relevant imformation about the gear and the fishery were also collected. In addition to the collection of data from the gears, visits to the landing areas and the public market in Bolinao were frequently carried out to verify species composition and abundance.

(2.3) Catch, Effort and Catch Per Unit Effort 
Catch and effort data were obtained from note-books of middlemen, and from interviews with the fishermen. The fishing power of each gear was standarized in order to get a reliable index of relative abundance. The unit of effort used for the trap fishery was the haul rather than hours or day assuming that fishermen knew optimum soak time for traps depending on the area. This approach was previously used by other researchers (Munro, 1974b; Stevenson and Stuart-Sharkey, 1980; Taylor and McMichael, 1983). The number of effective fishing hours was used as a standard measure of effort for the hook-and-line and spear fisheries. In the case of the spear fishery in which lights are used, a survey was conducted to see if the same candle power was used throughout the fishery. The results from the survey showed that the same attractive power was used. As a result there was no need to standarize the effort for this factor.

Estimated monthly catches were computed from sampling and interview data. For hook-and-line the monthly catch was calculated by

$$
\begin{aligned}
& \text { ETC = (CPUE x FT) } \\
& \text { where, FT = (men } \times \text { \# days } \times \text { ft }(\mathrm{h})) \\
& \text { men }=\text { the average number of fishermen, \# days = } \\
& \text { average number of fishing days per month, and ft }(\mathrm{h})= \\
& \text { average number of hours fishing per day. }
\end{aligned}
$$

For the spear the monthly catch was 
calculated by

$$
\text { ETC }=\operatorname{CPUE} \times(\text { men } x \text { \# boats } x \text { ft }(h) x \text { \# days })
$$

where, \# boats = average number of boats out per night.

For the trap fishery the monthly catch was calculated by

$$
\mathrm{ETC}=\mathrm{CPUE} \times \mathrm{ETH}
$$

where, ETH = estimated total number of traps hauled during the month.

\section{(2.4) Compilation of Length Data}

Length measurements were compiled into histograms of monthly length frequency and pooled length frequencies for the most abundant species. The width of size groups for the histograms depends on maximum fish length: a $1-\mathrm{cm}$ interval was used for species that reach $30-\mathrm{cm}$, a $2-\mathrm{cm}$ interval for $60-\mathrm{cm}$, and $5-\mathrm{cm}$ interval for 150-cm species (Anderson and Gutrenter, 1983).

A standard fish-measuring board graduated in centimeters $(\mathrm{cm})$ was used to measured the lengths. All lengths were taken from the anterior end of the fish, with the mouth closed to the tip of the tail for total length (TL) and to the posterior end of the hypural bone or the end of the fleshy caudal penduncle for standard length (SL). A linear regression was used to estimate the relationship between total length (TL) and standard length in $(\mathrm{cm})$ for the most important species. To test if location influenced the size of capture an 
analysis of variance was done for the trap fishery. (2.5) Length-weight Relationship

Weights were measured to the nearest gram whenever possible. Length-weight relationships were calculated for all the species for which adequate data was obtained. For the analysis, the power function:

$$
w=a L^{\star} b
$$

calculated by ordinary least squares on log-transformed data with bias correction was used where $W=$ weight in g, $\mathrm{L}=$ length in $\mathrm{cm}, \mathrm{a}$ and $\mathrm{b}$ are constants. (Saila, Recksiek, Prager, and Chen., 1980).

\section{(2.6) Fish Yield}

The fish yield ( $Y$ ) in $\mathrm{mt} / \mathrm{sq} \mathrm{km} / \mathrm{yr}$ for the rainy season was calculated using the formula that Alcala and Gomez (1985) used to estimated the fish yield of three reefs in the Philippines:

$$
Y=\frac{\text { Estimated total catch }(\mathrm{mt})}{\text { Reef area }(\mathrm{sq} \mathrm{km})}
$$

The reef and lagoon area were estimated from a chart of Bolinao Harbor (PCGS 4238; 1:20,000 scale) using a compensating polar planimeter. The area measured was that which completely enclosed the 
combined operational areas of the three fishing gears. The number of fishing days in one year was estimated to be 256. This value was estimated from the average fishing day obtained from interviews and middlemen note-books for each fishing gear. Fishing was limited by strong currents, and rough seas brought by local storms and occasional typhoons.

III.

\section{Results}

\section{(3.1) Description of the Trap Fishery}

There is a very active fishery around Silaki island. A large diversity of fisheries exist, ranging from daily collections of marine invertebrates on the reef flats by women and children to small bamboo rafts and motorized boats (bancas). The fishing grounds for the trap fishery are the southwest, northern and eastern parts of the reef and the lagoon surrounding Silaki (see Fig 1). There is less activity in the southern part because those grounds are the main passageway for the lagoon.

Fish traps are locally called (nasa or bubo). The size and the shape are constant and only bamboo straps are used for their construction. There are about 450 to 500 traps with the following dimensions: $51 \mathrm{~cm}$ long, 45 cm wide, $13 \mathrm{~cm}$ high with a mesh size of $2.5 \mathrm{~cm}$ (see Fig 2 and 3). Fish trapping is conducted year round. There are 34 fishermen involved in fish trapping: some are full time, while others only part time. The bulk of the 

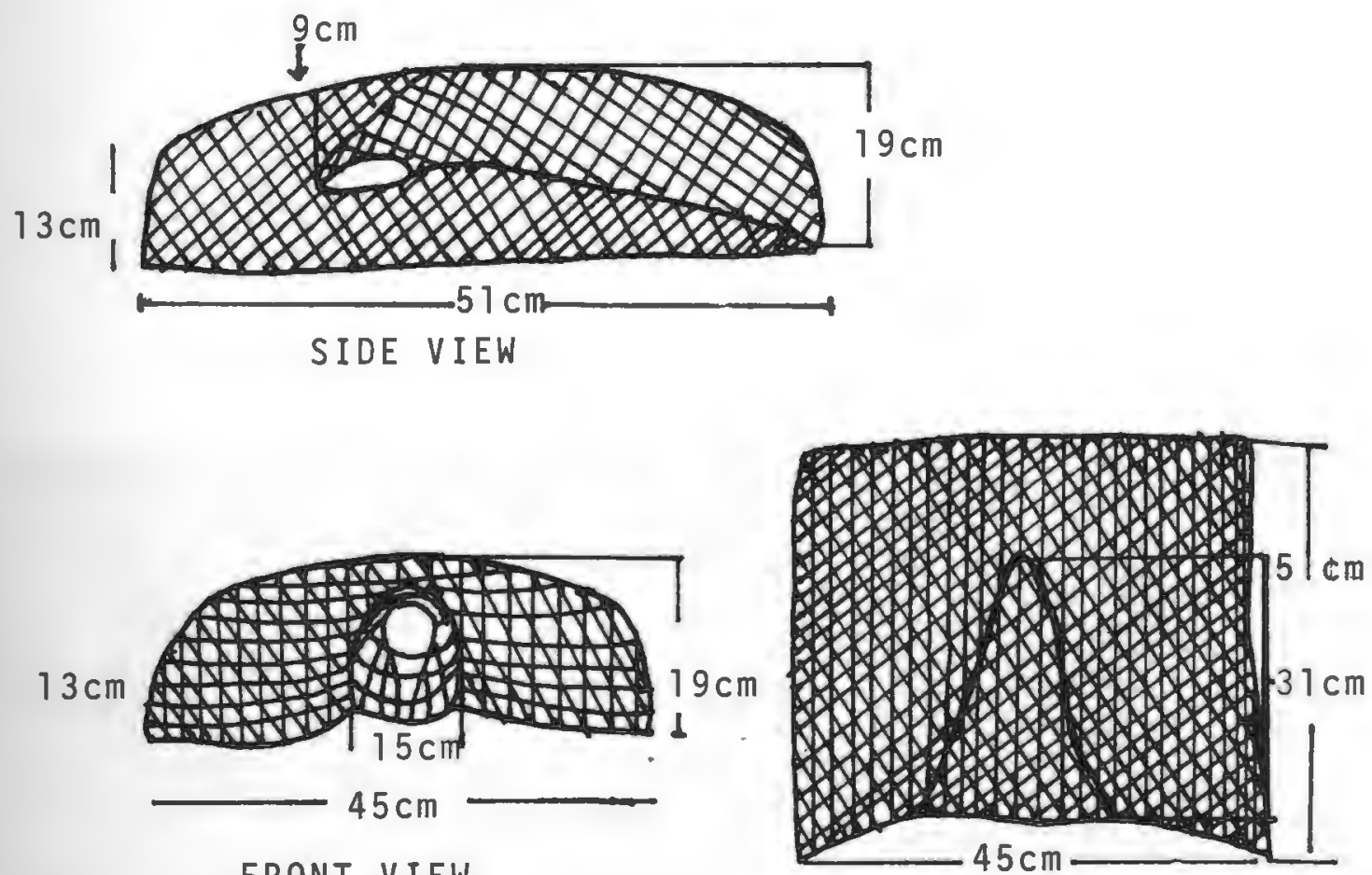

FRONT VIEW

TOP VIEW
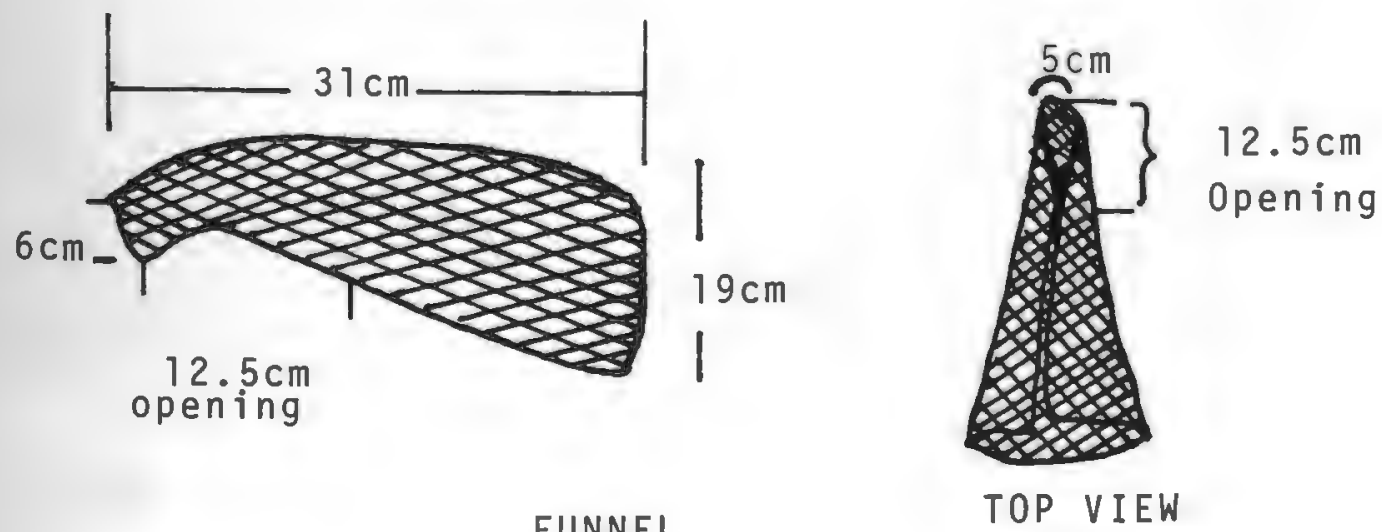

FUNNEL

\section{FIGURE 2}

Detail description of a fish trap use to catch coral reef fishes in Cape Bolinao, Philippines. 


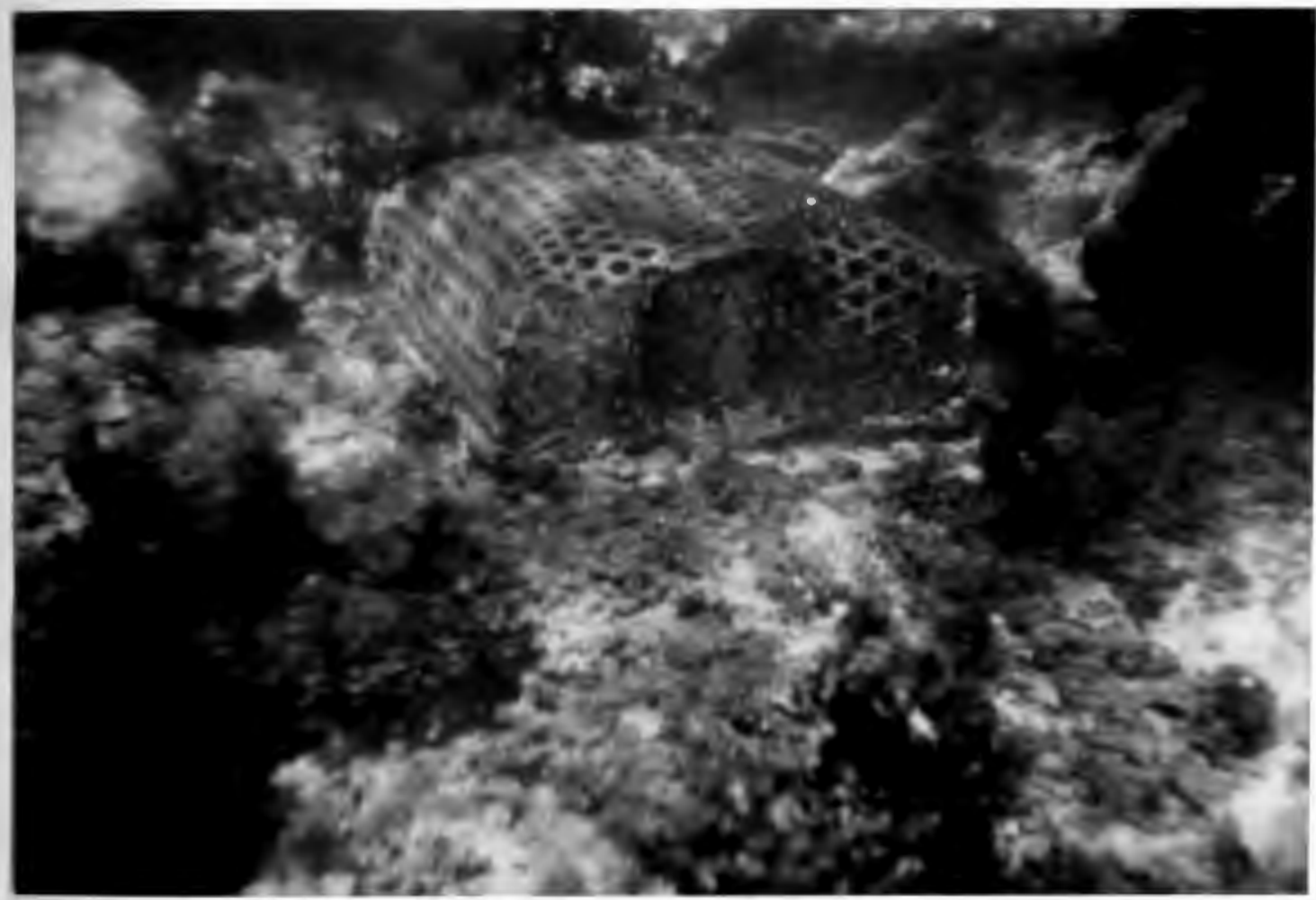

FIGURE 3

Picture showing a fish trap in the water. 
fishing is done from light flat bamboo rafts knows as Balsa, constructed entirely of bamboo (see Fig 4). A typical raft is made of 6 to 8 bamboo poles each approximately 5 meters long and $20 \mathrm{~cm}$ wide, held together with bamboo straps.

The fishing operation is as follows: The traps are set on the outer edge of the reef or near coral patches inside the lagoon at depths of 2 to 5 feet during low tide and 5 to 10 feet during high tide. As an average, fishermen set groups of 20 to 25 traps. These are soaked for 24 hours. The fisherman pulls his raft to the fishing grounds, and upon reaching it he ties a rope from the raft to his waist so he will not separate from the raft. He dives until he finds the first trap. The traps are set individually and covered with pieces of coral in order to simulate a coral head (see Fig 5). The traps are usually set in the same location or moved to a different location within the lagoon or close to the reef. Most of the traps are set with the funnel oriented toward a coral patch. Setting the traps in this direction demonstrates knowledge of fish behavior on the part of the fishermen. Traps were not baited, but some fishermen felt that leaving a fish in the trap can act as an attractant, luring other fishes into the trap.

(3.2) Catch, effort and catch per unit effort

The trap fishing effort from 1002 individual trap 


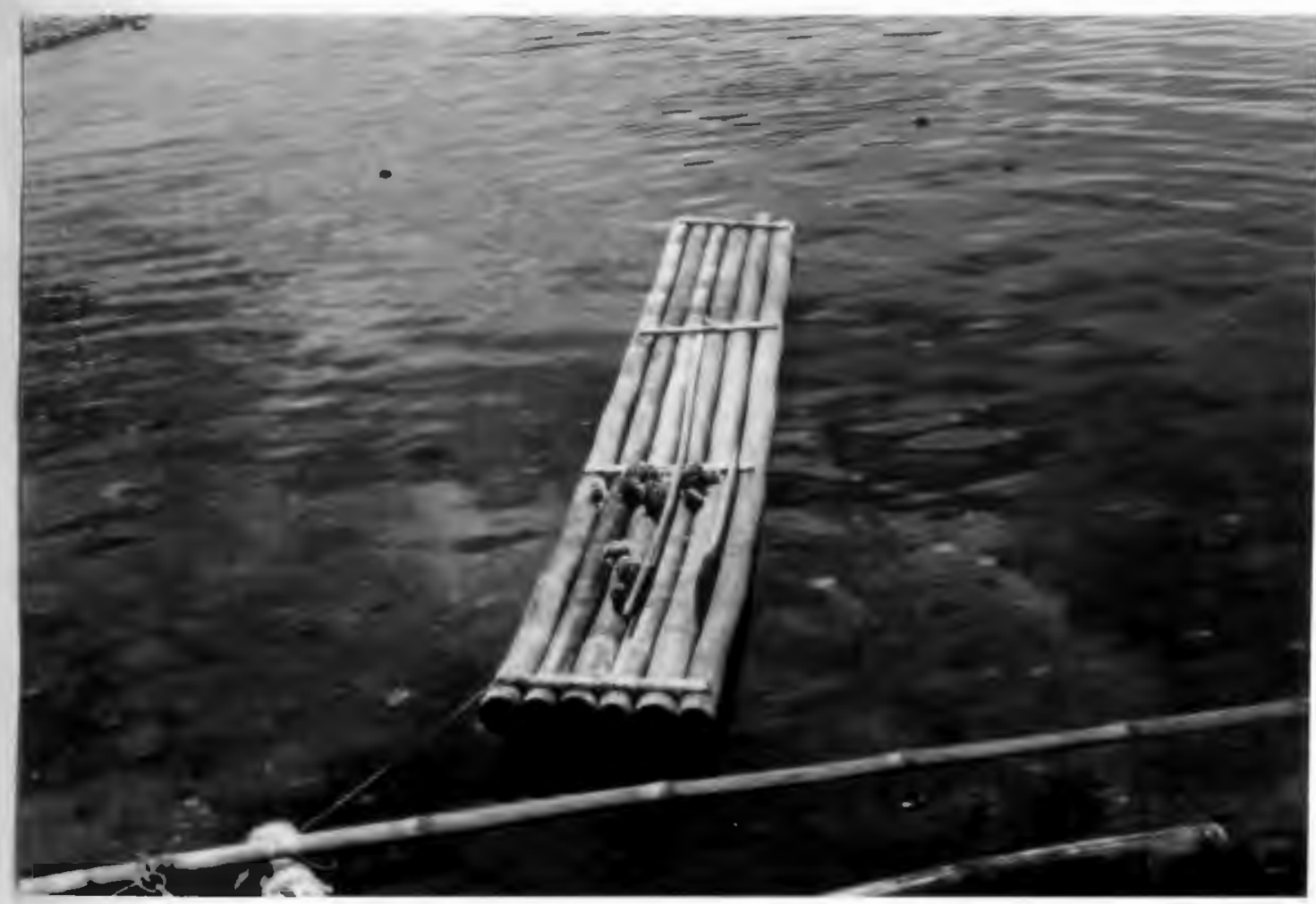

\section{FIGURE 4}

Picture of a typical bambo raft used for navigation and fishing operations by trap fishermen around Cape Bolinao, Philippines. 


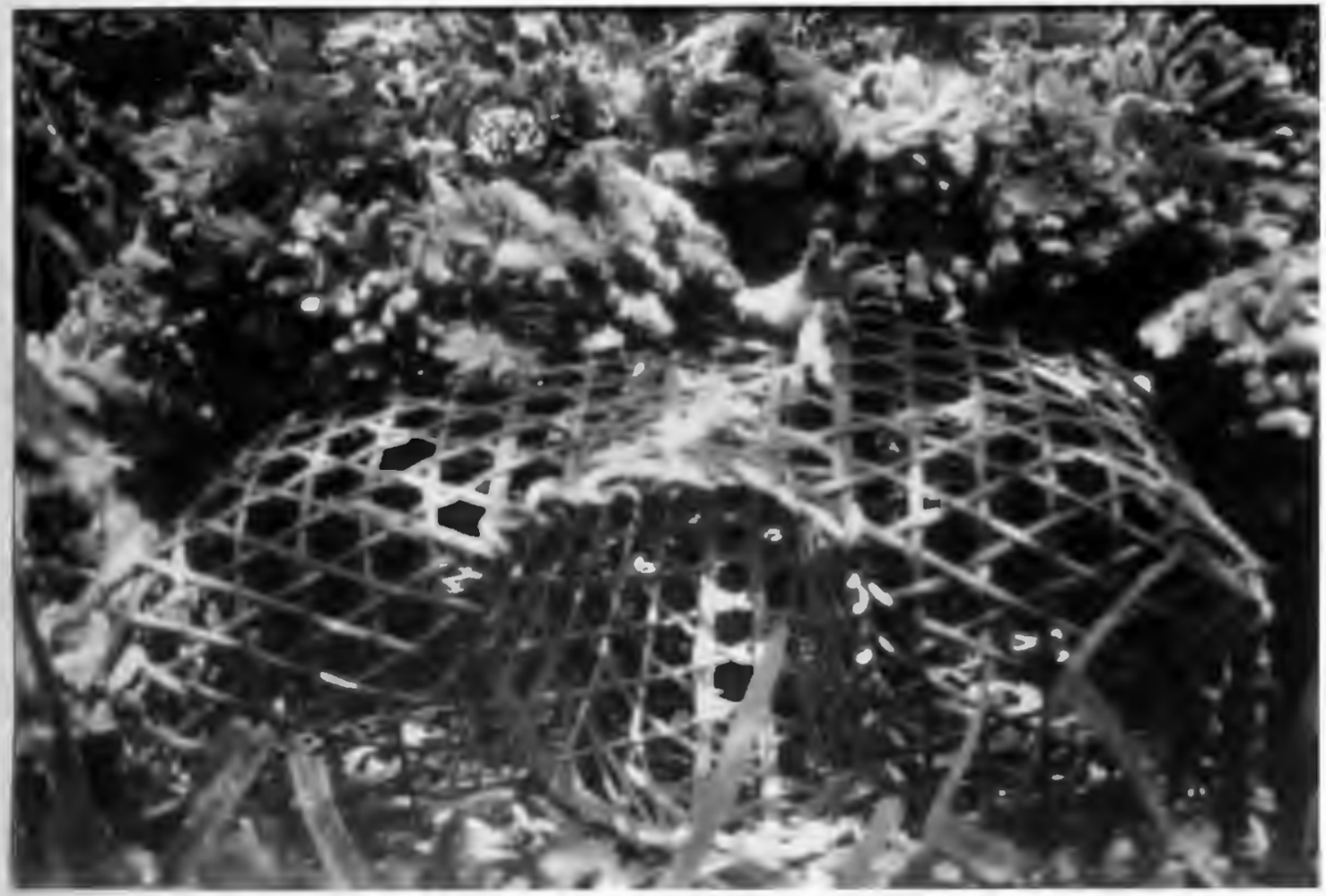

FIGURE 5

Picture of atrap cover with coral in order to simulated a coral head. 
samples yielded a catch of 4274 fishes weighing 127.8 kgs. The monthly average catch per haul (CPUE) was $0.129 \mathrm{kgs}(\mathrm{s.d.}=0.018)$ and the average number of fish per haul was $4.0(\mathrm{s.d} .=1.17)$. Figures 6 and 7 show the relationship between catch and CPUE versus total effort. From both figures, the effect of the number of traps deployed on the catch and CPUE can be seen. The traps sampled outside the reef yielded 57.8 percent of the total weight and 52.1 percent of the fish. The inside fishery yielded 42.1 percent of the weight and 47.8 percent of the fish (see Table 1). A soak time of 24 hours was the most common. Soak times of 1 to 3 days occurred due to adverse weather and sea conditions, which made the handling of the raft difficult. Number of monthly sampled traps, total weight of catches, total number of fish, average catch per trap hauled, and average number of fish per trap are given in Table 2. Catch per unit effort was calculated for the four most abundant families: Siganidae, Labridae, Scaridae and Serranidae (Fig 8). Summaries of trap catches, effort and CPUE by sampling day and Location are given in Appendices 1 and 2.

It was not possible to obtain a valid estimation of the total catches during this study based on limited, time or manpower to continually relocate and reinterview fishermen to determine if they remained actively engaged in the fishery throughout the study 
Total Catch vs Total Effort

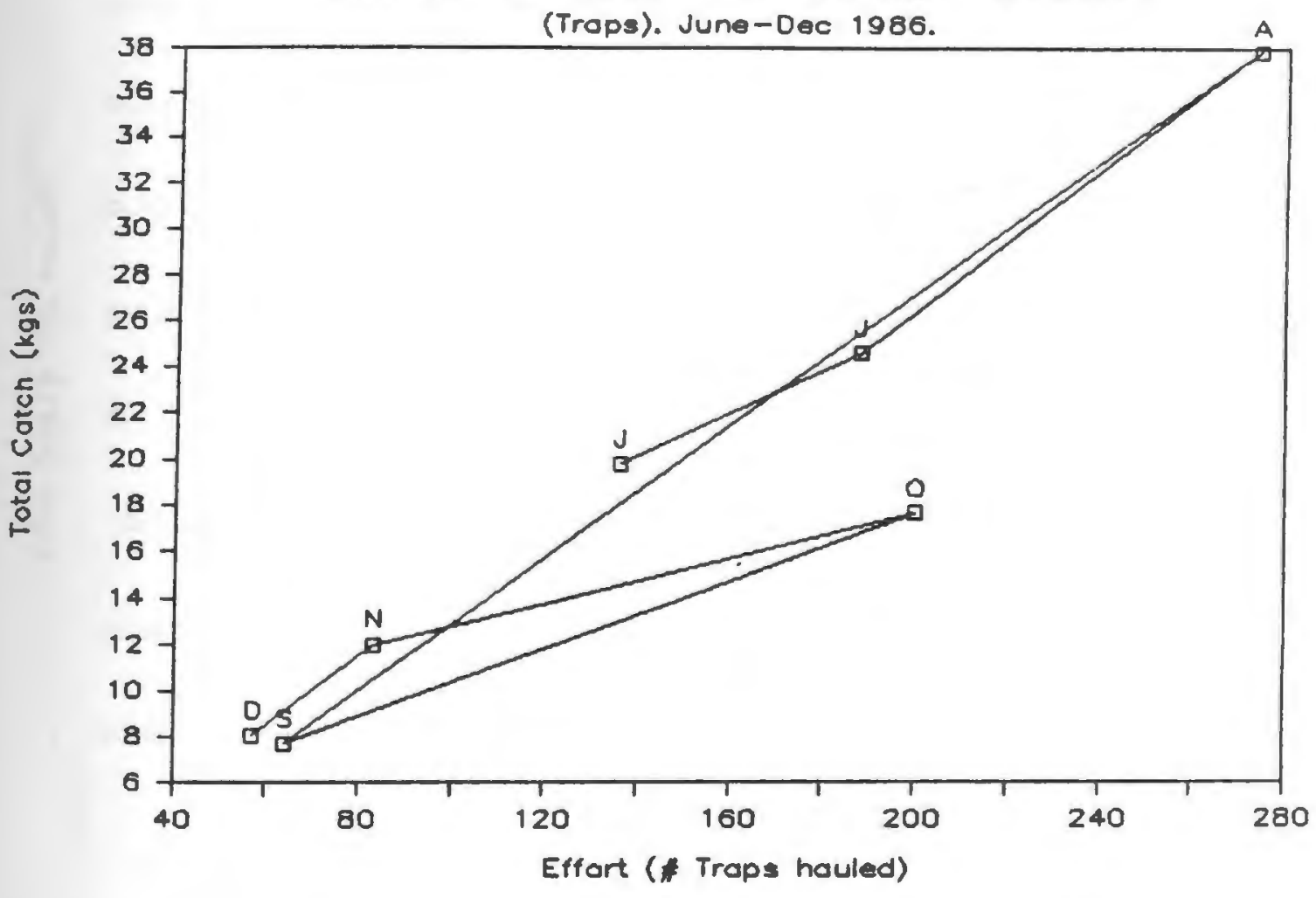

FIGURE 6

Relationship between catch and total effort for the trap fishery. The months are represented by the letters: $\mathrm{J}=$ June, $\mathrm{J}=\mathrm{Ju} 1 \mathrm{y}, \mathrm{A}=$ August, $\mathrm{S}=\mathrm{Sep}-$ tember, $\mathrm{O}=$ October, $\mathrm{N}=$ November, $\mathrm{D}=$ December. 


\section{Total CPUE vs Total Effort}

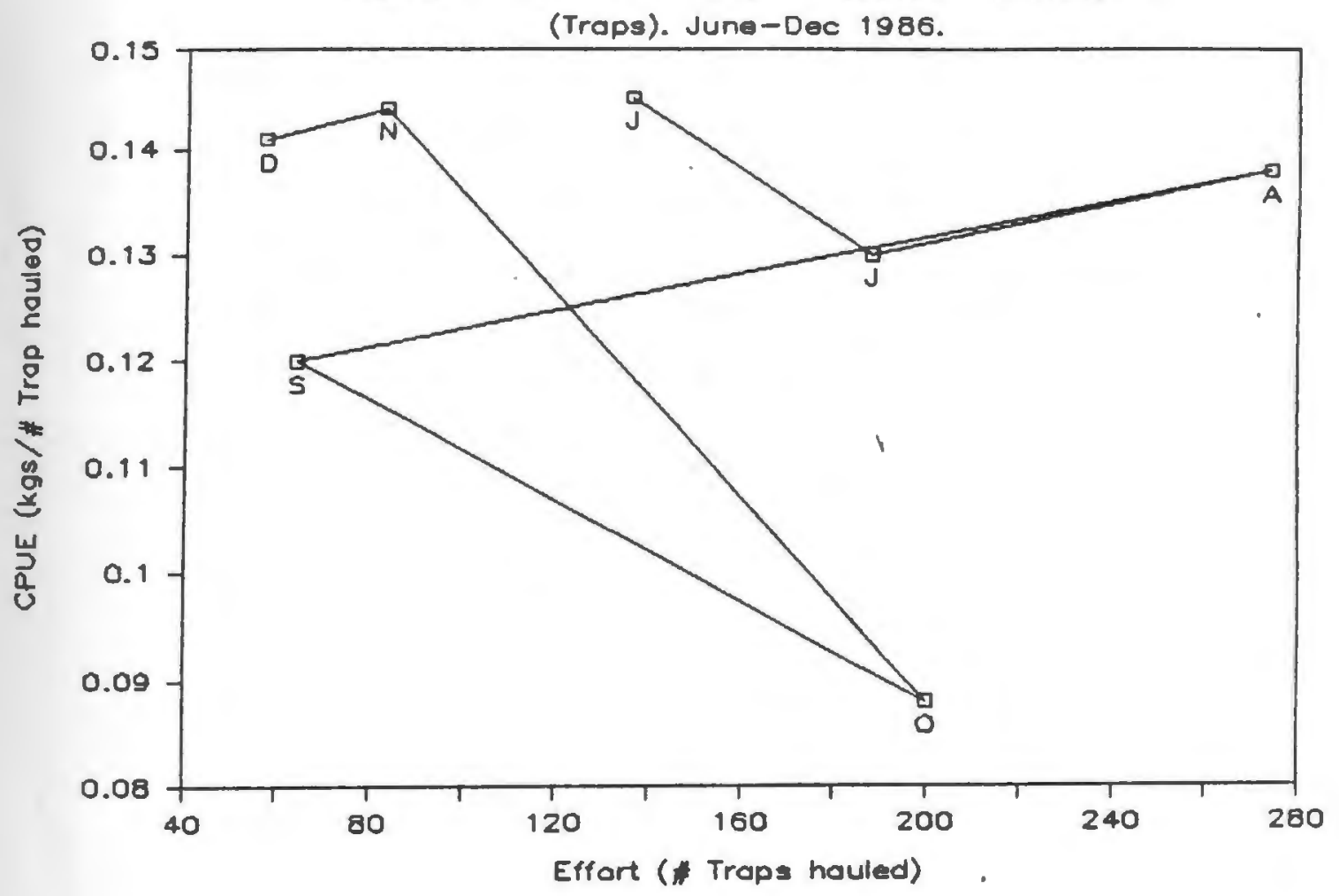

\section{FIGURE 7}

Relationship between CPUE and total effort for the trap fishery. The months are represented by the letters: $\mathrm{J}=$ June, $\mathrm{J}=\mathrm{July}, \mathrm{A}=$ August, $\mathrm{S}=$ September, $\mathrm{O}=$ October, $\mathrm{N}=$ November, $\mathrm{D}=$ December. 


\section{Table 1}

Total weight and number of fish produced by the trap
fishery. Cape Bol inag, philippines. For the period June to December 1986

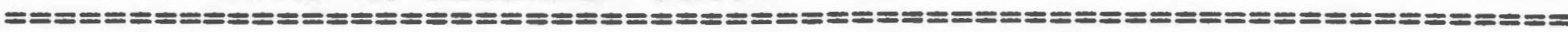
Area T. We ight (kgs) $\%$ (T.W)

Number $\%$ (n)

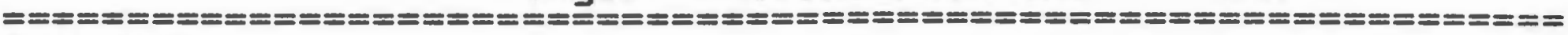
Inside

fringing reef

53.92

57.8

2046

47.8

fringing reef

73.89

42. 1

2228

52.1

Tota 1

127.81

99.9

4274

99.9

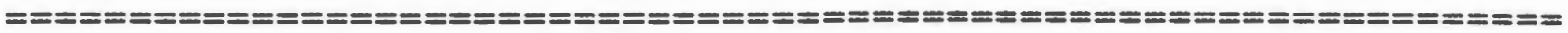


Table 2 Sumary of monthly trap catches. Cape Bol inao, Phil ippines.

\begin{tabular}{|c|c|c|c|c|c|c|c|c|}
\hline Months & $\begin{array}{l}\text { * Traps } \\
\text { Hauls } \\
\text { (sampled) }\end{array}$ & $\begin{array}{l}\text { Soak } \\
\text { Tine } \\
\text { (days) }\end{array}$ & $\begin{array}{l}\text { Number of } \\
\text { Species }\end{array}$ & $\begin{array}{c}\text { Number } \\
\text { of Fish } \\
\text { ( } n \text { ) }\end{array}$ & $\begin{array}{l}\text { Weight } \\
\text { of Fish } \\
\text { (Kgs) }\end{array}$ & $\begin{array}{l}\text { Number } \\
\text { Fish per } \\
\text { Haul }\end{array}$ & $\begin{array}{l}\text { Weight } \\
\text { per haul }\end{array}$ & $\begin{array}{l}\text { Estimate } \\
\text { total } \\
\text { Catch (kg) }\end{array}$ \\
\hline $\begin{array}{l}\text { June } \\
\text { July } \\
\text { Pugust } \\
\text { September } \\
\text { October } \\
\text { November } \\
\text { December }\end{array}$ & $\begin{array}{r}136 \\
188 \\
274 \\
64 \\
200 \\
83 \\
57\end{array}$ & $\begin{array}{r}6.9 \\
12.8 \\
13.5 \\
3 \\
5 \\
2.75 \\
3\end{array}$ & $\begin{array}{l}59 \\
69 \\
69 \\
36 \\
55 \\
48 \\
41\end{array}$ & $\begin{array}{r}542 \\
985 \\
1320 \\
226 \\
546 \\
365 \\
290\end{array}$ & $\begin{array}{r}19.82 \\
24.61 \\
37.86 \\
7.73 \\
17.69 \\
12 \\
8.1\end{array}$ & $\begin{array}{l}4 \\
5 \\
5 \\
4 \\
2 \\
5 \\
6\end{array}$ & $\begin{array}{r}0.145 \\
0.13 \\
0.138 \\
0.12 \\
0.088 \\
0.144 \\
0.141\end{array}$ & $\begin{array}{l}509 \\
458 \\
484 \\
422 \\
309 \\
506 \\
497\end{array}$ \\
\hline Totals & 1002 & & & 4274 & 127.81 & & & \\
\hline
\end{tabular}

Pve. Soak Timel=

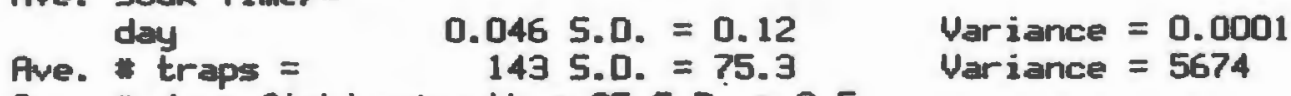

Ave. days fishing/month $=255.0 .=2.5$

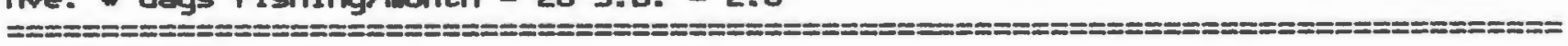


FIGLRE 8̊..

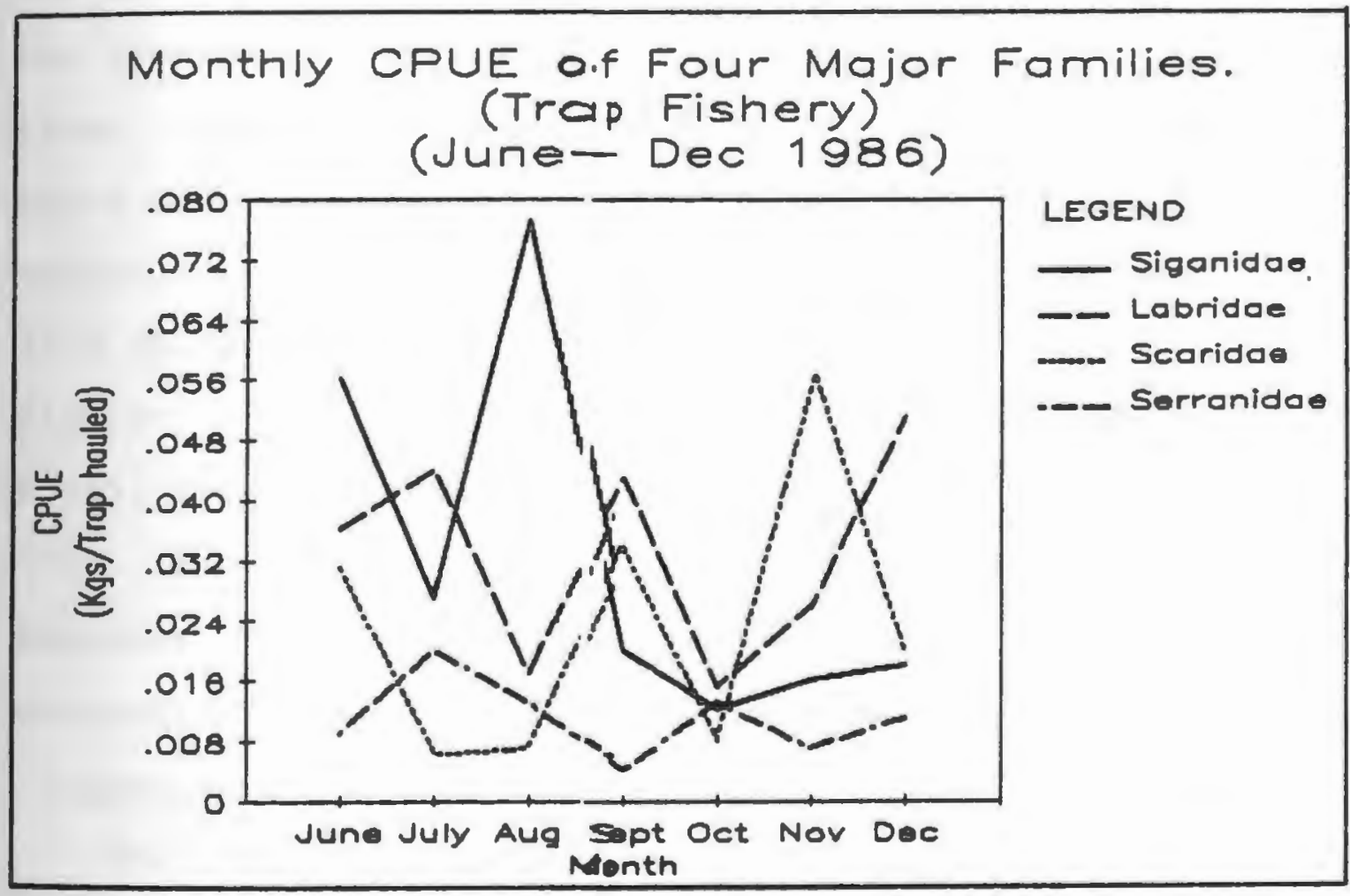


period. It was difficult to tell when fishermen had permanently ceased fishing traps because part-time fishermen sometime did not use then for periods of one to five consecutives days.

\section{Outside reef}

on an annual basis, probably more traps are set on the outside reef rather than inside the lagoon. The 456 traps sampled from the outside reef during the six month period produced 2228 fish weighing $73.8 \mathrm{kgs}$. The monthly average catch per trap was $0.127 \mathrm{Kgs}$ (s.d.=0.023), ranging from 0.087 to $0.159 \mathrm{kgs}$. The highest catch rate occurred in June where CPUE was 0.159 , followed by a CPUE of 0.152 in July. The CPUE in this area exhibited a regular decline from June to December. Table 3 shows a summary of monthly trap catches, effort and CPUE outside the reef.

\section{Lagoon environment}

The 456 traps sampled from the lagoon environment yielded 2046 fish weighing $53.9 \mathrm{kgs}$. The monthly average catch per trap hauled was $0.131 \mathrm{kgs}$ (s.d.=0.046) ranging from 0.010 to $0.206 \mathrm{kgs}$. The highest catch rate occurred in December where CPUE was 0.206 , followed by a CPUE of 0.180 in November. The CPUE in this area exhibited a decline in september and October, increasing to a higher value in December and November. A summary of monthly trap catches, effort and CPUE inside the lagoon is given in Table 4. 
Table 3 Sumary of monthly trap catches in the outer edge of

a coral reef lagoon. Cape Bolinao, Philppiness.

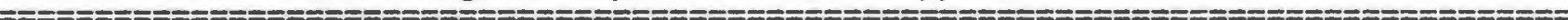

* Traps/ Saak Number of Number Weight Number Height Estimate
Manths Hauls Time Species of Fish of Fish Fish per per haul Total
(sampled) (days)

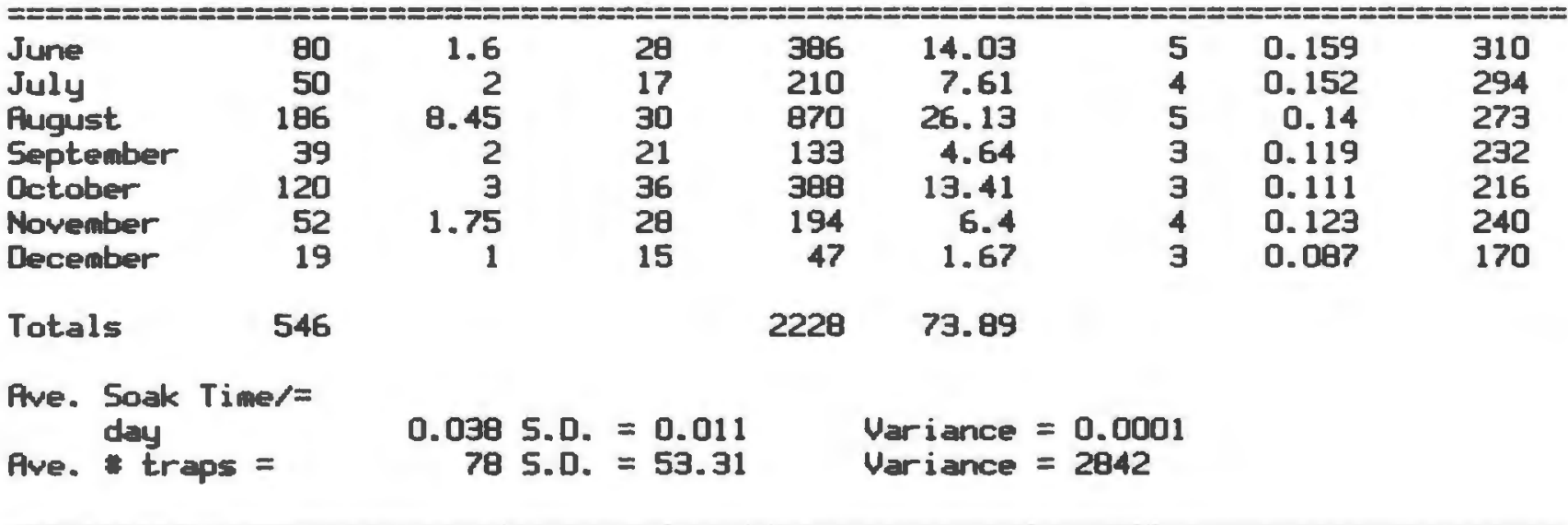


Table 4 Sumary of monthly trap catches inside a coral reef lagoon. Cape Bol inao, Phil ippines.

\begin{tabular}{|c|c|c|c|c|c|c|c|c|}
\hline Months & $\begin{array}{l}\text { Traps } \\
\text { Hauls } \\
\text { (sampled) } \\
=======\end{array}$ & $\begin{array}{l}\text { Soak } \\
\text { Time } \\
\text { (days) } \\
======\end{array}$ & $\begin{array}{l}\text { Number of } \\
\text { Species } \\
========\end{array}$ & $\begin{array}{l}\text { Number } \\
\text { of } F \text { ish } \\
(n)\end{array}$ & $\begin{array}{l}\text { Weight } \\
\text { of Fish } \\
\text { (Kgs) } \\
===+==\end{array}$ & $\begin{array}{l}\text { Number } \\
\text { Fish per } \\
\text { Haul } \\
======\end{array}$ & $\begin{array}{l}\text { Weight } \\
\text { per haul } \\
=======\end{array}$ & $\begin{array}{l}\text { Estimate } \\
\text { Total } \\
\text { Catch (kg) } \\
========\end{array}$ \\
\hline $\begin{array}{l}\text { June } \\
\text { July } \\
\text { Rugust } \\
\text { September } \\
\text { October } \\
\text { November } \\
\text { December }\end{array}$ & $\begin{array}{r}56 \\
138 \\
88 \\
25 \\
80 \\
31 \\
38\end{array}$ & $\begin{array}{r}5.3 \\
10.8 \\
5 \\
1 \\
2 \\
1 \\
2\end{array}$ & $\begin{array}{l}31 \\
52 \\
39 \\
15 \\
19 \\
20 \\
26\end{array}$ & $\begin{array}{r}156 \\
775 \\
450 \\
93 \\
158 \\
171 \\
243\end{array}$ & $\begin{array}{r}5.78 \\
17 \\
11.73 \\
3.1 \\
4.28 \\
5.61 \\
6.42\end{array}$ & $\begin{array}{l}3 \\
6 \\
5 \\
4 \\
2 \\
6 \\
6\end{array}$ & $\begin{array}{r}0.103 \\
0.123 \\
0.133 \\
0.123 \\
0.053 \\
0.18 \\
0.206\end{array}$ & $\begin{array}{r}168 \\
200 \\
216 \\
200 \\
86 \\
293 \\
335\end{array}$ \\
\hline Totals & 456 & & & 2046 & 53.92 & & & \\
\hline $\begin{array}{l}\text { Ave. Soak } \\
\text { day } \\
\text { Ave. \# tra }\end{array}$ & $\begin{array}{l}\text { Time/= } \\
\text { aps }=\end{array}$ & $\begin{array}{l}0.053 \\
65.14\end{array}$ & $\begin{array}{l}\text { 5.0. }=0.1 \\
\text { 5.0. }=37 .\end{array}$ & $\begin{array}{l}023 \\
.12\end{array}$ & $\begin{array}{l}\text { Var iance } \\
\text { Variance }\end{array}$ & $\begin{array}{l}=0.0005 \\
=1378\end{array}$ & & \\
\hline
\end{tabular}


The summary of the monthly total catch and total catch by location have been plotted in Fig 9. From this graph a pattern of seasonality can be observed between the two areas. During periods of strong weather conditions more traps tend to be deployed inside the lagoon than outside the lagoon. From Fig 10 it can be observed that the number of traps deployed is directly related to the catch in both areas. A regression analysis of the catch versus effort was done and shows a positive relation between both values (see Fig 11). Figure 12 shows the total CPUE for the trap fishery by location. The total number of fish caught by location is plotted in Fig 13. Comparing Fig 10 and 13, it can be seen that the number of fish is directly related to the number of traps. All the information collected suggests that the variation of effort and catch between locations is strongly influenced by weather conditions. (3.3) Catch composition.

The diversity of species caught for the trap fishery was very high; 127 species were collected. Of these, only 10 species made up the bulk of the fishery, with the family Siganidae accounting for 31.5 percent of the catch (see Table 5). Labrinid species were most numerous with 25 species observed. Pomacentrids were also abundant with 15 species. Siganus spinus was the most abundant specie in both areas accounting $41.8 \%$ in the outer edge and 14.98 inside the lagoon. The results 


\section{FIGURE 9.}

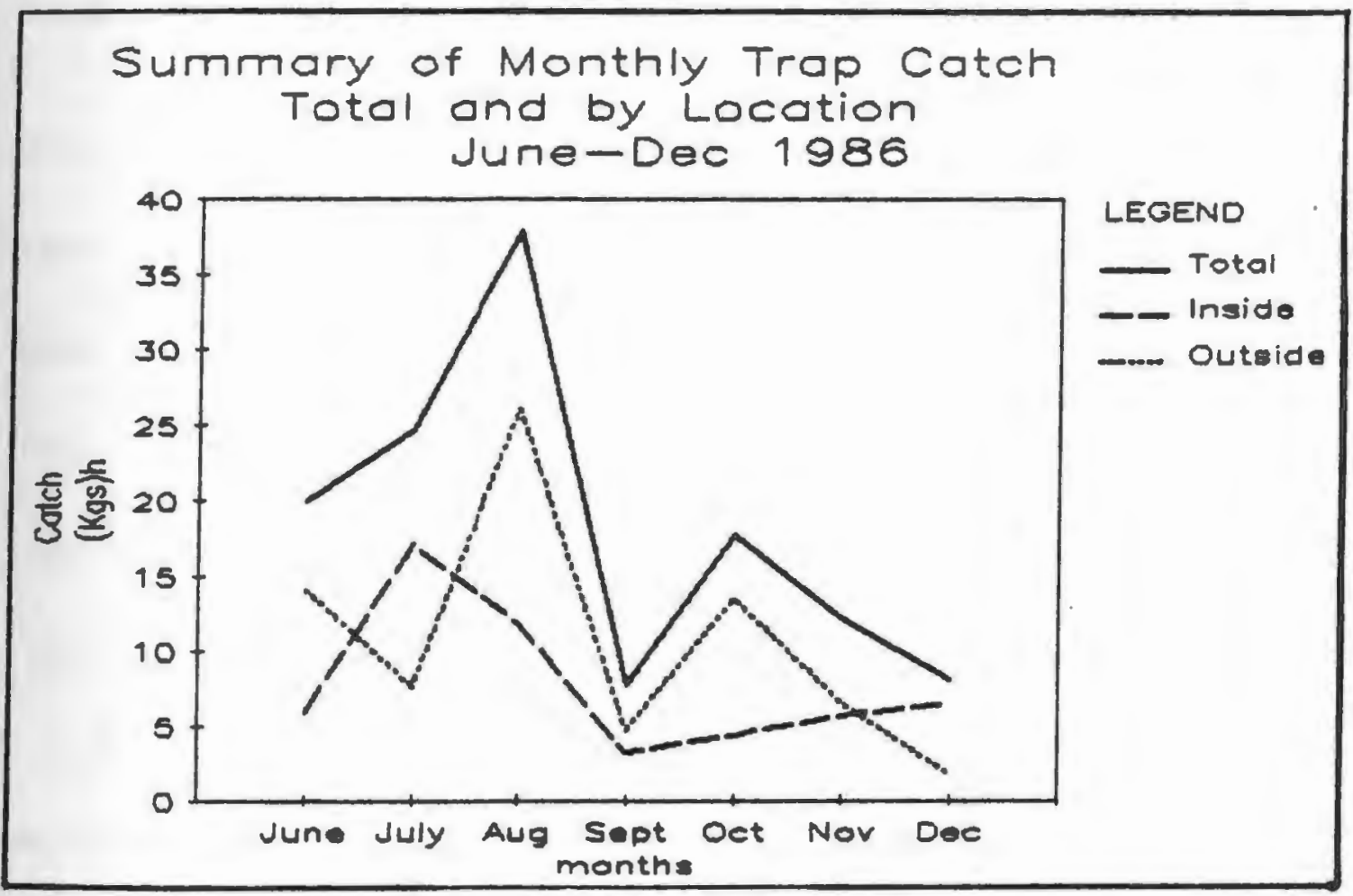


FIGURE 10.

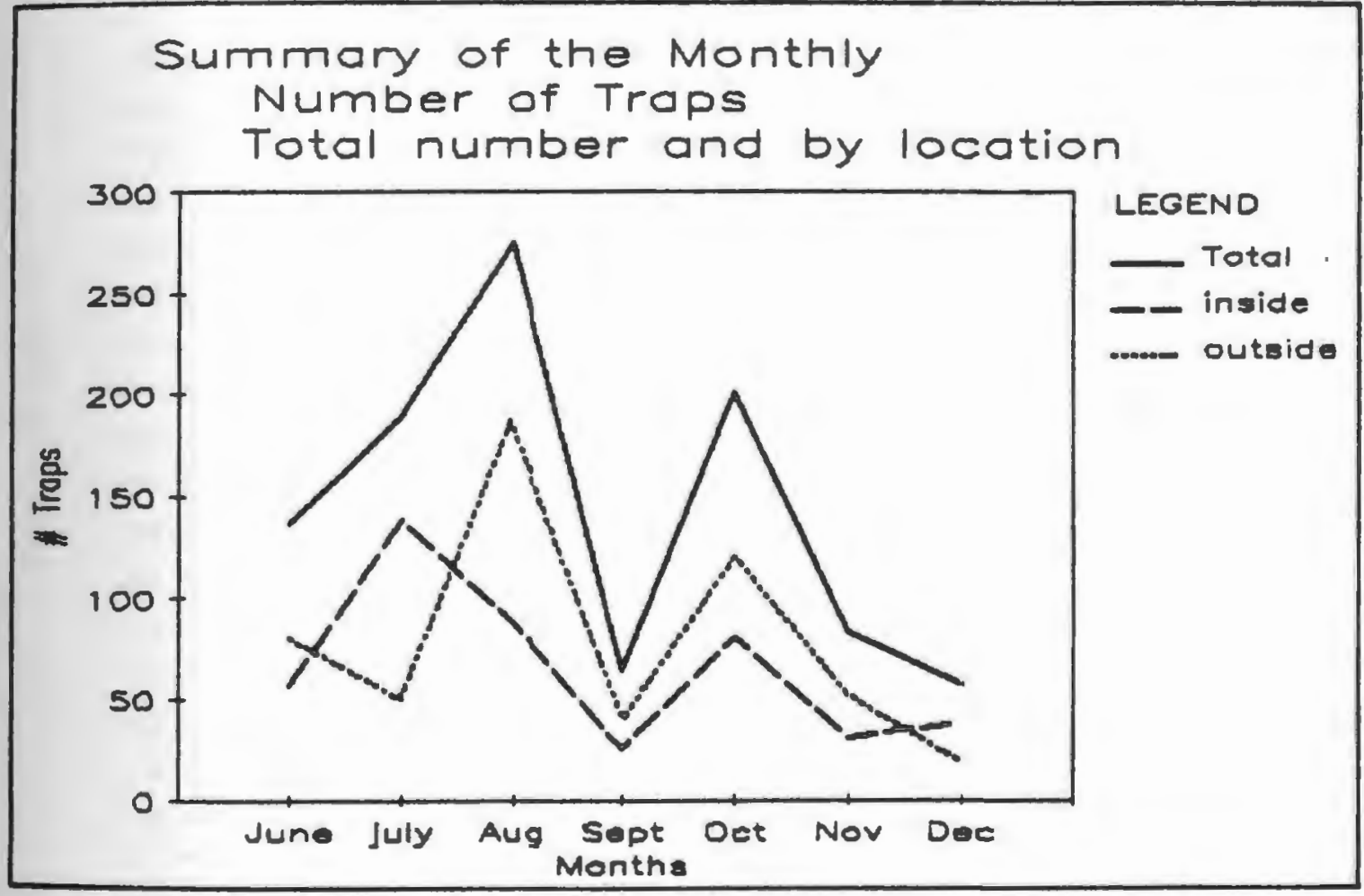




\section{Linear Regression}

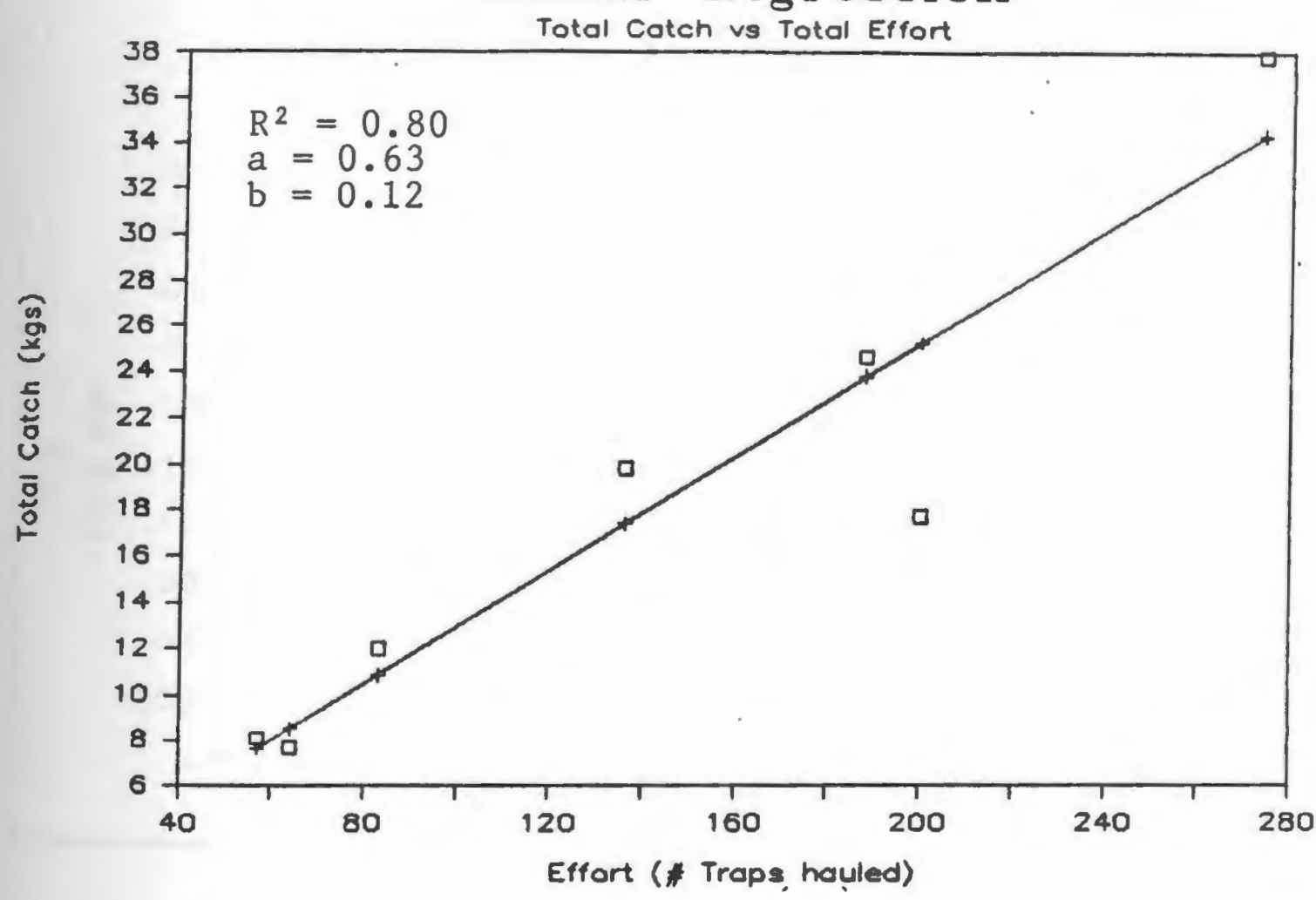

\section{FIGURE 11}

Liniar regression between total catch and total effort for the trap fishery. Cape Bolinao. JuneDecember 1986. 
FIGURE 12.

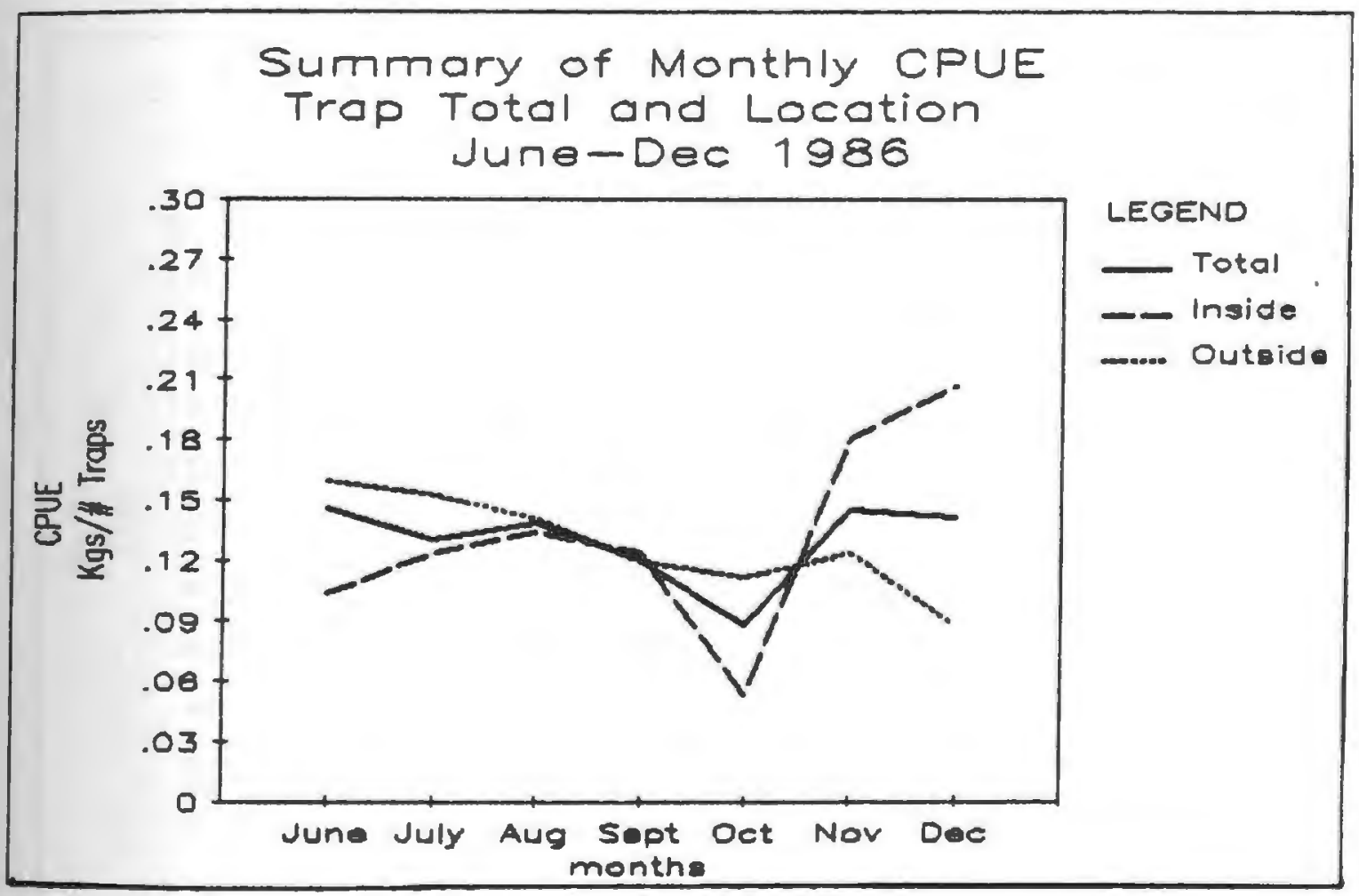


FIGURE 13.

Summary of Monthly Number of Fishes Trap Total and by Location June-Dec 1986

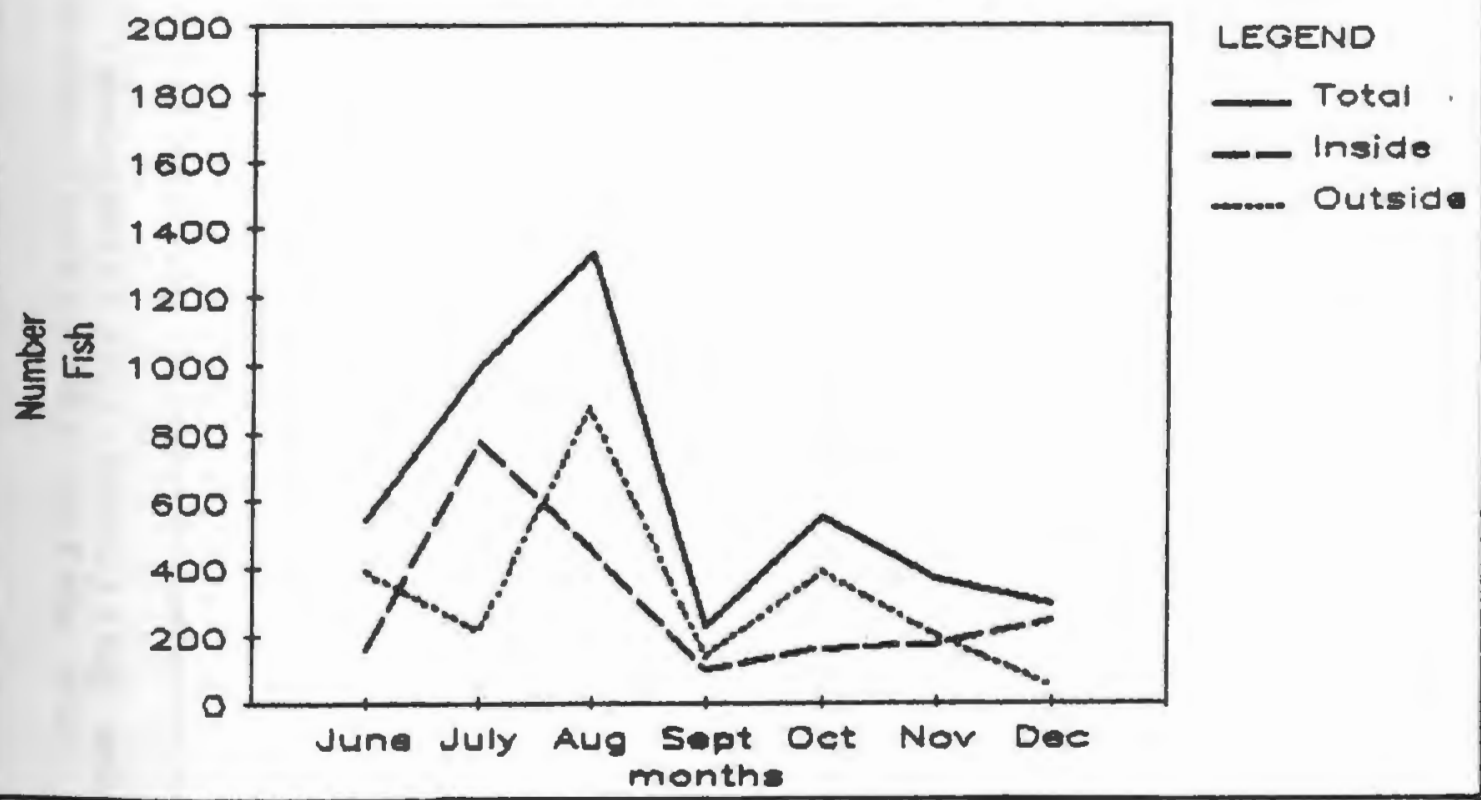


Table 5

Summary of the Major families represented in trap catches. Cape Bolinao, Philippines.

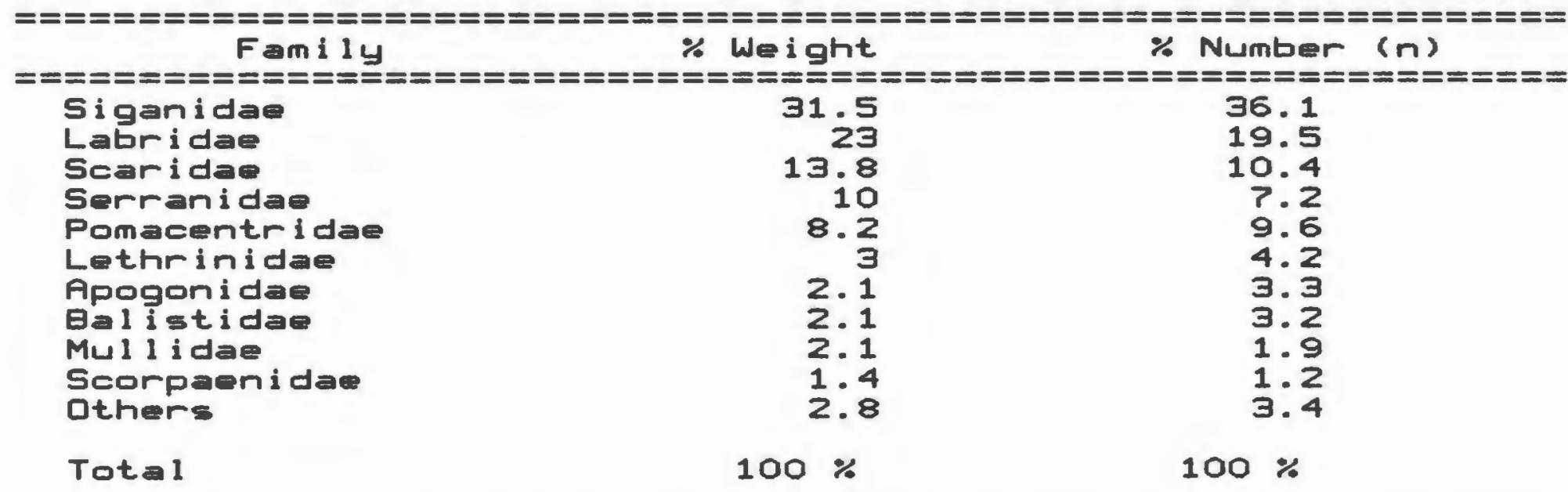

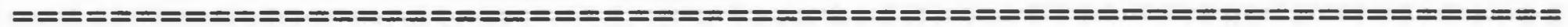


from a $7 \times 4$ contingency table (Appendix 3) showed a significant relationship between time (months) and species by location $\left(X^{\wedge} 2=508, d . f .18, P<0.00\right)$ inside the reef and $\left(X^{\wedge} 2=521\right.$, d.f.18, $\left.P<0.00\right)$ outside the reef. A repeated measure ANOVA between the four most abundant species was used to examine whether location influences the catch of the traps. i.e. the two treatment were inside and outside areas. The ANOVA indicated that there was no a siignificant differences between the two areas $(F=3.66, d . f .=3,3 \mathrm{P}=.16)$. Outside reef

Ninety 90 species representing 18 families were collected in this area. The family siganidae was the most abundant comprising 42.28 of the total catch. The families comprising more than 18 of the total weight caught and number are shown in Table 6 . The 7 most abundant species were: Siganus spinus, Siganus canaliculatus, Scarus rhodopterus, Labrid A, Stagastes sp., Cheilinus trilobatus, and Epinephalus merra. These species accounted for 73.78 of the total number and 67.8 of the total catch. A list of the species composition by number, weight and relative abundance is given in Appendix 4.

Lagoon environment

101 species representing 23 families were collected in this area. The family Labridae was the most abundant accounting 26.58 of the total catch. This is followed 
Table 6

Major families reprosented in catches of traps in the outer edge of a coral reef lagoon. Cape Bol inao. Phi 1 ippines.

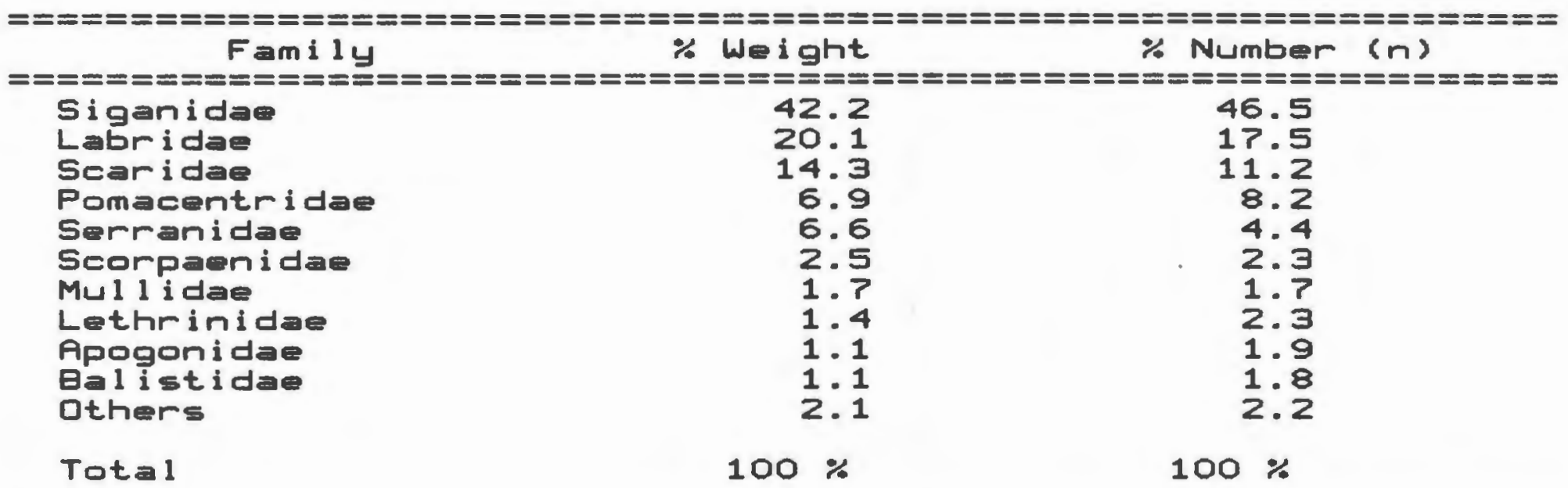

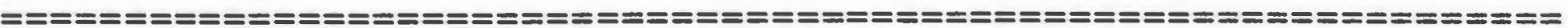


by Siganidae with $16.8 \%$ The families comprising more than 18 of the total weight caught and number are shown in Table 7. Although more species were represented in this area the species abundance was similar between the two areas. The same 7 species accounted for $58.3 \%$ of the total number and $56.8 \%$ of the total catch. A list of the species composition by number, weight, and relative abundance is given in Appendix 5.

(3.4) Notes on the Biology

Samples of Siganus spinus, S. canaliculatus, Scarus rhodoptherus, Labrid A, Stagastes sp., Cheilinus trilobatus, Epinephalus merra, and Apogon sp. were analyzed for length composition and length-weight relationship by location. Table 8 gives the relationships between total length (TL) and standard length (SL) and standard length to total length for the mentioned species by location.

Length Frequency Distribution.

The length frequency distribution for the eight species considered are plotted in Appendix 6. Siganus spinus

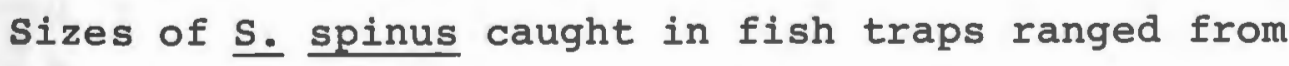
7 to $16 \mathrm{~cm}$ with an average size of $10.5 \mathrm{~cm}$ (s.d.=0.099) inside the lagoon and from 7 to $18.5 \mathrm{~cm}$ with an average size of $11.9 \mathrm{~cm}$ (s.d.=0.067) outside the reef. The results from the analysis of variance showed that the mean size from the two areas were significantly 
Table $?$

Mejor families represented in trap catches inside - coral reef lagoon. Cape Bolinao, Philippines.

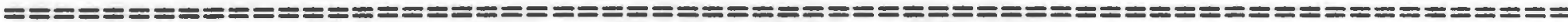
Fam i 14 \% Weight \% Number (n)

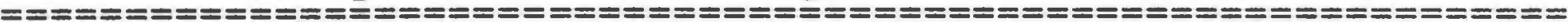

\begin{abstract}
Labr i dae
Siganidae

Serranidae

Scaridae

Pomacentri dae

Lethrinidae

Apoqoni dae

Bal ist idae

Mu 11 i dae

othere
\end{abstract}

Tota 1
26.5

16.8

14.7

13

9.5

5.2

3. 6

3.4

2. 2

5. 1
21.5

24.5

10.3

9.4

11

6.4

4. 8

4. 7

2.6

4.8

$100 \%$

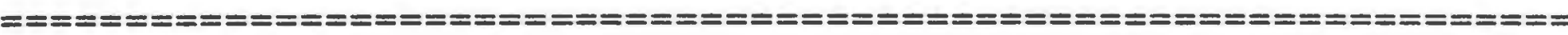


Table 8 Relationship of Total Length (TL) to Standard Length (SL) and Standard Length (SL) to Total Length (TL) for eight species from the Trap

Fishery Inside and outside a fringing reef. Capo Bolineo,

Philippines.

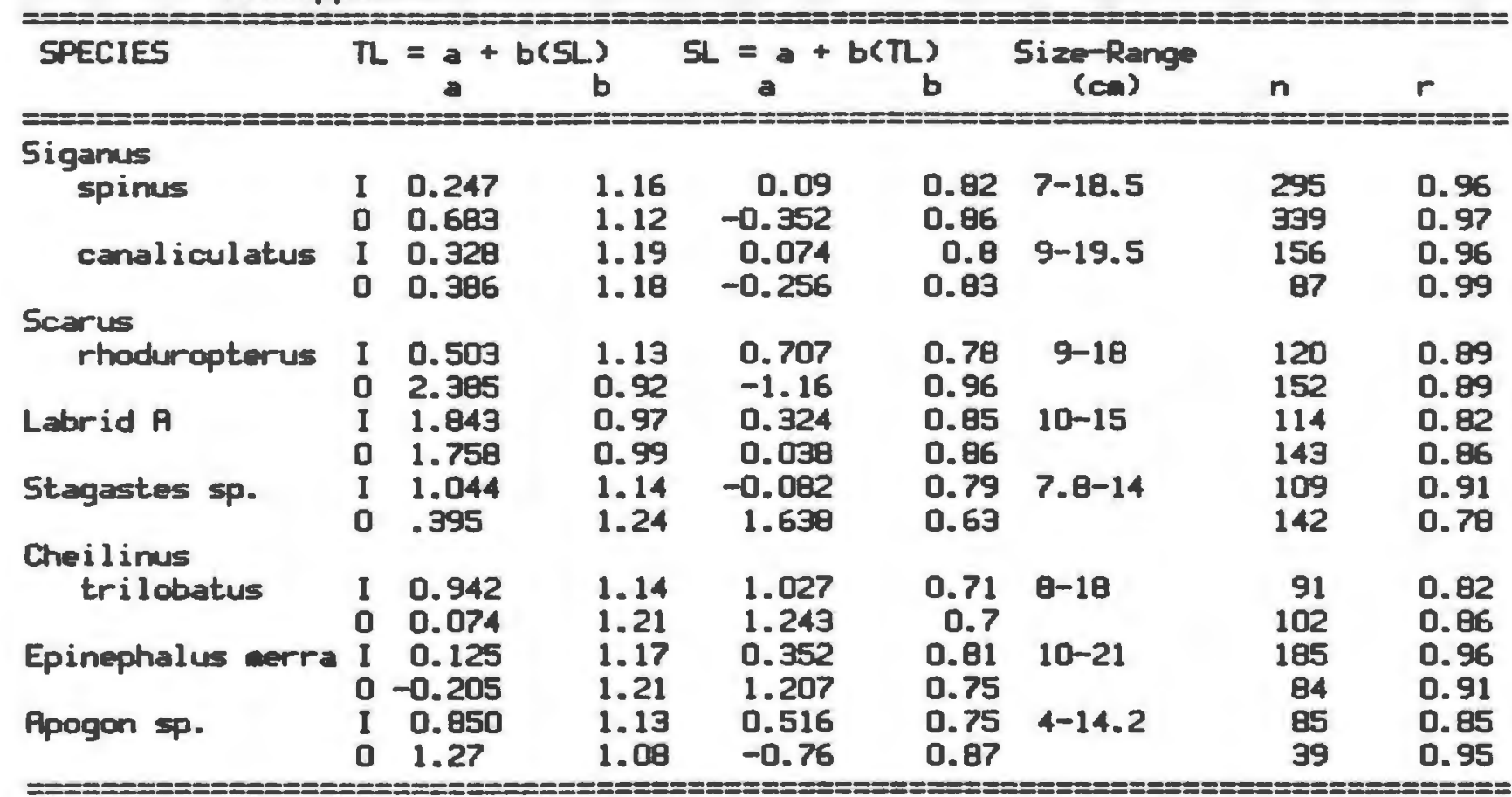

$I=$ Inside fringing reef

0 = Outside fringing reef 
different $(P=0.001)$.

Siganus canaliculatus

Sizes of S.canaliculatus ranged from 9 to $19.5 \mathrm{~cm}$ with an average of $11.5 \mathrm{~cm}\left(s . \mathrm{d}_{0}=0.130\right)$ inside the lagoon, and from 9.5 to $19.5 \mathrm{~cm}$ with an average of 13.3 $\mathrm{cm}$ (s.d.=0.281) outside the reef. Results from the analysis of variance showed that the mean lengths of the two areas were significantly different $(P=0.0026)$. Scarus rhoduropterus

S. rhoduropterus ranged from 9 to $16.5 \mathrm{~cm}$ with an average size of $11.8 \mathrm{~cm}\left(s . d_{0}=0.095\right)$ inside the lagoon, and from 9.5 to $18.5 \mathrm{~cm}$ with an average of $12.2 \mathrm{~cm}$ (s.d.=0.092) outside the reef. The analysis of variance showed that there was a significant difference between the mean lenghts of the two areas $(P=0.006)$.

\section{Labrid A}

Sizes of Labrid A ranged from 10 to $15 \mathrm{~cm}$ with a mean of $12.6 \mathrm{~cm}$ (s.d.=0.11) inside the lagoon, and 10 to $15 \mathrm{~cm}$ with a mean of $13 \mathrm{~cm}(\mathrm{~s} . \mathrm{d} .=0.088)$ outside the reef. The analysis of variance showed that the means of these samples were not significantly different $(P=0.291)$.

\section{Stagastes sp.}

Stagastes sp. ranged from 7.8 to $14 \mathrm{~cm}$ with and average size of $10.9 \mathrm{~cm} \quad(\mathrm{~s} . \mathrm{d} .=0.131)$ inside the lagoon, and 8.3 to $13.9 \mathrm{~cm}(\mathrm{s.d} .=0.107)$ outside the reef. The resuts of the analysis of variance showed that the 
means of these samples were significantly different $(P=0.002)$.

\section{Cheilinus trilobatus}

Cheilinus trilobatus ranged from 10 to $18 \mathrm{~cm}$ with an average size of $12 \mathrm{~cm} \quad(s . d .=0.163)$ inside the lagoon, and 8.7 to $15.3 \mathrm{~cm}$ with an average size of 11.4 (s.d.=0.11) outside the reef. The results from the analysis of variance showed that the mean lengths were significantly different $(P=0.043)$.

\section{Epinephalus merra}

Epinephalus merra ranged from 10 to $21 \mathrm{~cm}$ with an average size of $13.6 \mathrm{~cm}(\mathrm{s.d.}=0.147)$ inside the lagoon, and from 10 to $19.5 \mathrm{~cm}$ with an average size of $14.8 \mathrm{~cm}$ (s.d.=0.235) outside the reef. The analysis of variance showed no significant differences between the mean lengths of the two locations $(P=0.107)$.

\section{Apogon sp.}

Apogon sp. ranged from 3.6 to $14.2 \mathrm{~cm}$ with an average size of $10 \mathrm{~cm}(\mathrm{s.d} .=0.156)$ inside the lagoon, and from 5.7 to $14.2 \mathrm{~cm}$ with an with an average size of $9.8 \mathrm{~cm}\left(\mathrm{~s} . \mathrm{d}_{.}=0.188\right)$ outside the reef. The analysis of variance between the two samples showed that mean length of these samples were not significantly different $(P=0.446)$.

Length-weight relationships

The length-weight relationships for the eight species considered for the trap fishery are presented 
in Table 9. Results from the statistical test between the slope of the two areas for each of the species showed no significant differences $(P<0.05)$ between these species. Slope (b) values from the length-weight relationship were tested for uniformity by the construction of 958 confidence intervals (Fig 14).

The length-weight relationship for each species are plotted in Appendix 7.

(3.5) Description of the Hook-and-Line Fishery.

Hook-and-line fishing took place 1 to $3 \mathrm{~km}$ away from the reef break in the outer reef slope of Santiago Island. This rocky bottom is an excellent fishing ground endowed with numerous species which inhabit or make temporary visits to this bottom. One of the most important points in successful hook-and-line fishing is to locate the habitat and the migrating depth of the fish to be caught, and then to place the hooks accurately in this range. Fishermen of Santiago Island used a triangulation method to determine their position in the fishing grounds. This method consists of the use of mountains or special features of the coast line as points of reference. This method is widely used in coastal communities throughout the world (Forman, 1970; Pollnac, 1976).

There were approximately 13 fishermen involved in hook-and-line fishing for bottom fishes around Santiago Island. Most fishermen operated individually on a 
Table 9 Relationship of total length (TL) to weight (W) for eight species from the trap fishery. where $a$ and $b$ are constants.

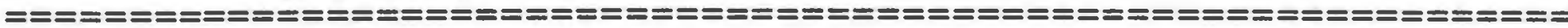
SPECIES W.

ax (TL) $\sim$ b $S i z e-R a n g e$

$=$

$$
\text { b }(\mathrm{cm})
$$

n

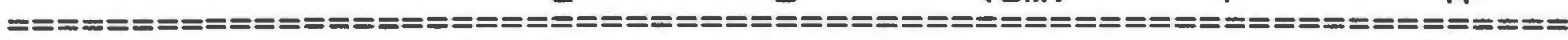
Siganus

spinus

canal iculatus

0. 01

8. 39

Scarus rhoduropterus

Labrid $A$

0. 026

Stagastes sp.

Cheilinus trilobatus

Epinephalus merra

Apogon sp.

$\begin{array}{ll}3.11 & 7-18.5 \\ 3.15 & 9-19.5 \\ 2.86 & 9-18 \\ 2.87 & 10-15 \\ 2.57 & 7.8-14 \\ 2.3 & 8-18 \\ 3.47 & 10-21 \\ 1.86 & 4-14.2\end{array}$

0.92

0. 97

0.92

0. 91

0.058

0.108

0. 003

o. 254

o. 83

0.86

0.92

0. 81

355

247

276

259

269

192

273

125

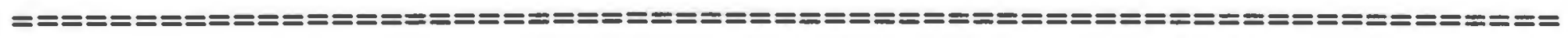




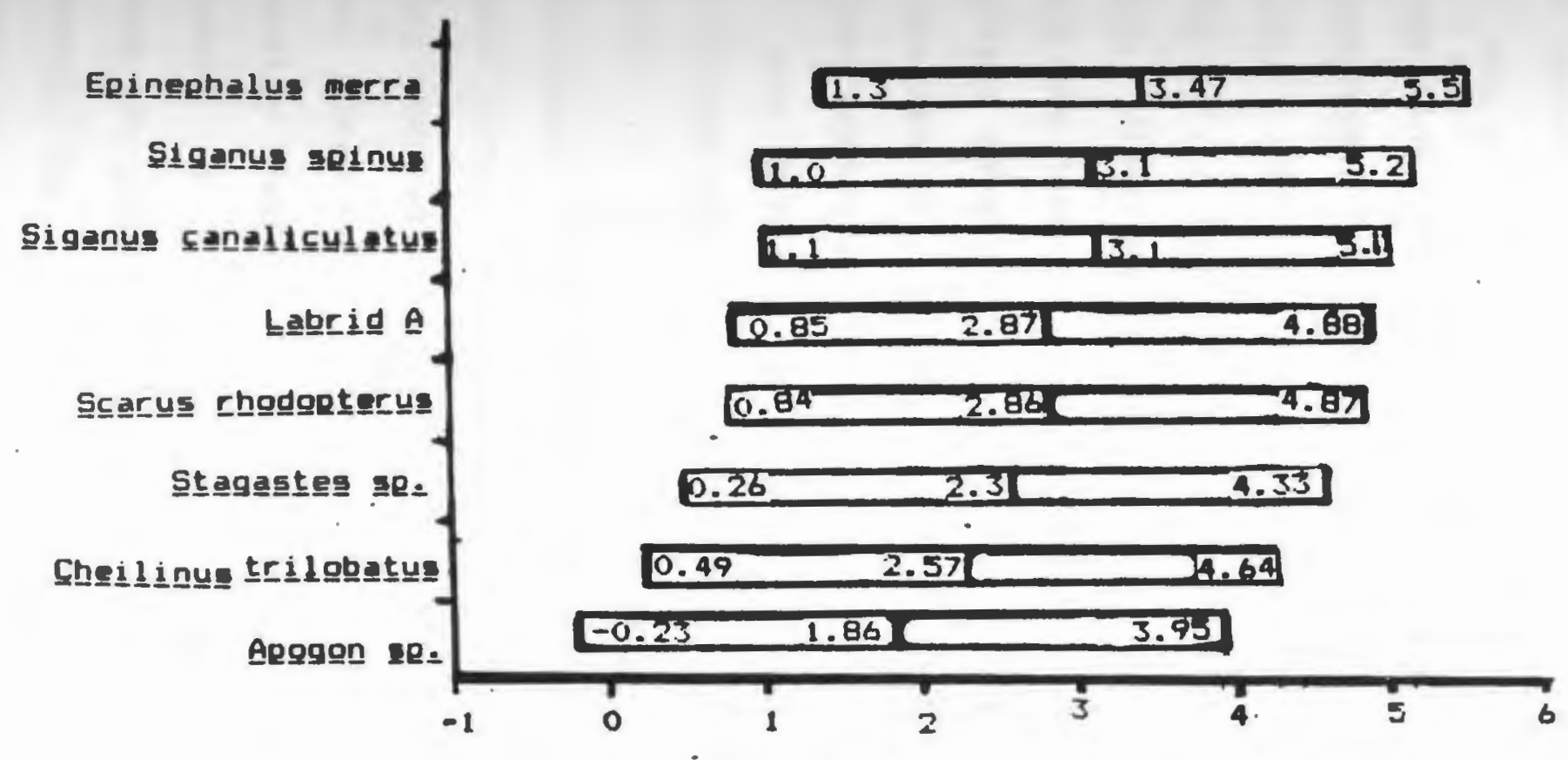

FIGURE 14

Ninety-five percent confidence intervals for the slope values from the length-weight relationship of eight

species from the trap fishery. 
subsistence fishing basis. In addition to angling, fishermen were engaged in some other types of supplementary fishing activity, such as crewing for a Basnig (Bagnet), gillnet, or using other gears inside the lagoon.

The fishing gear consisted of a single monofilament nylon line, a swivel, sinker and hooks (Fig 15). One to three hooks may be placed on a single line. Some fisher- men made their own hooks from stainless steel (Fig 16). A variety of baits were used, including live bait, fish pieces and artificial lures. The choice of bait was based on the availability of live bait and the species sought. The most frequently used bait among the fishermen of Santiago Island was squid. Artificial lures were used for tuna and other pelagic species.

The fishing operation is carried out as follows: Fishermen usually put out from shore individually or in pairs in an small non-motorized banca (Fig 17). The operation took place from sunset to sunrise. Fishermen spent 2 to 3 hours getting to the fishing grounds. When they reached the fishing grounds a candle was lit and the banca was allowed to drift. The first hour is usually spent fishing for bait. The bait (squid or pieces of fish) was cut in strips and attached to the hook. In addition to bait, fishermen would at times spread the head and the guts in the water in order to increase fishing effectiveness. Fishermen stayed in the 


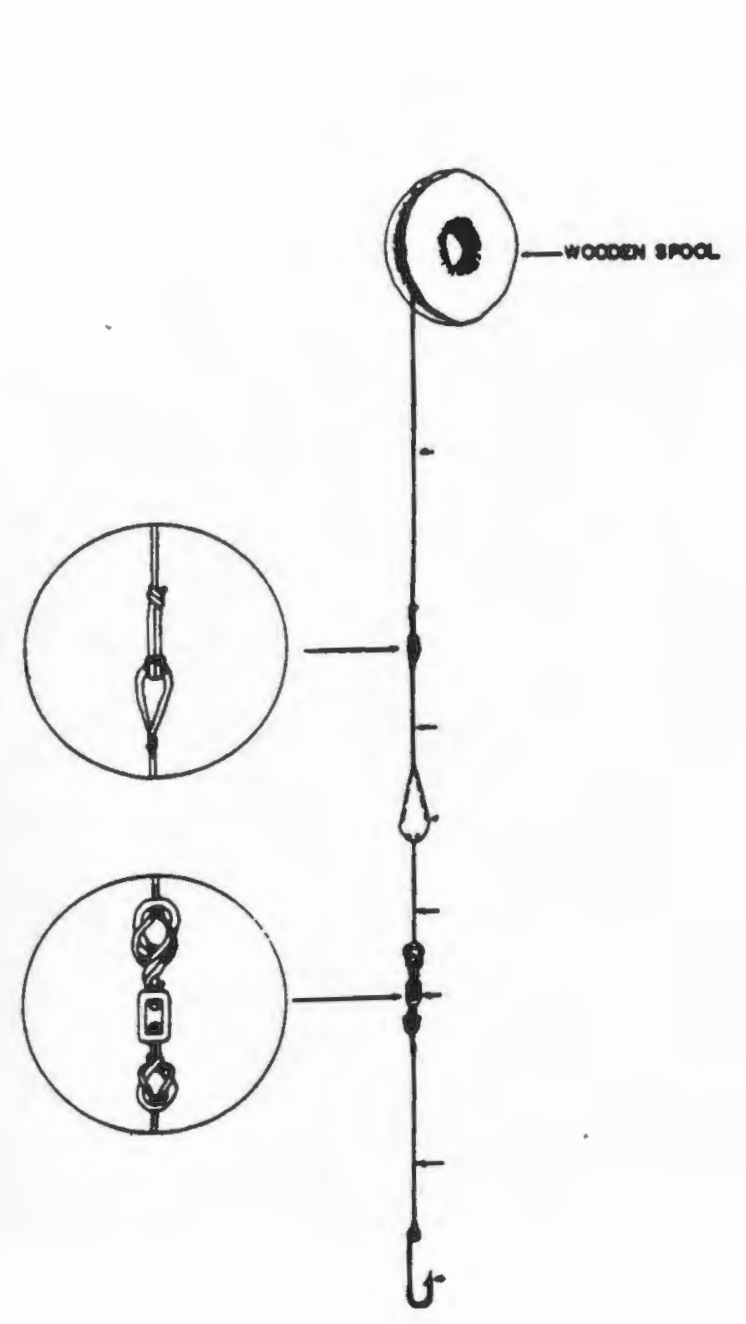

FIGURE 15.

Fishing gear used for the hool-and-line fishery in Cape Bolinao. Philippines 


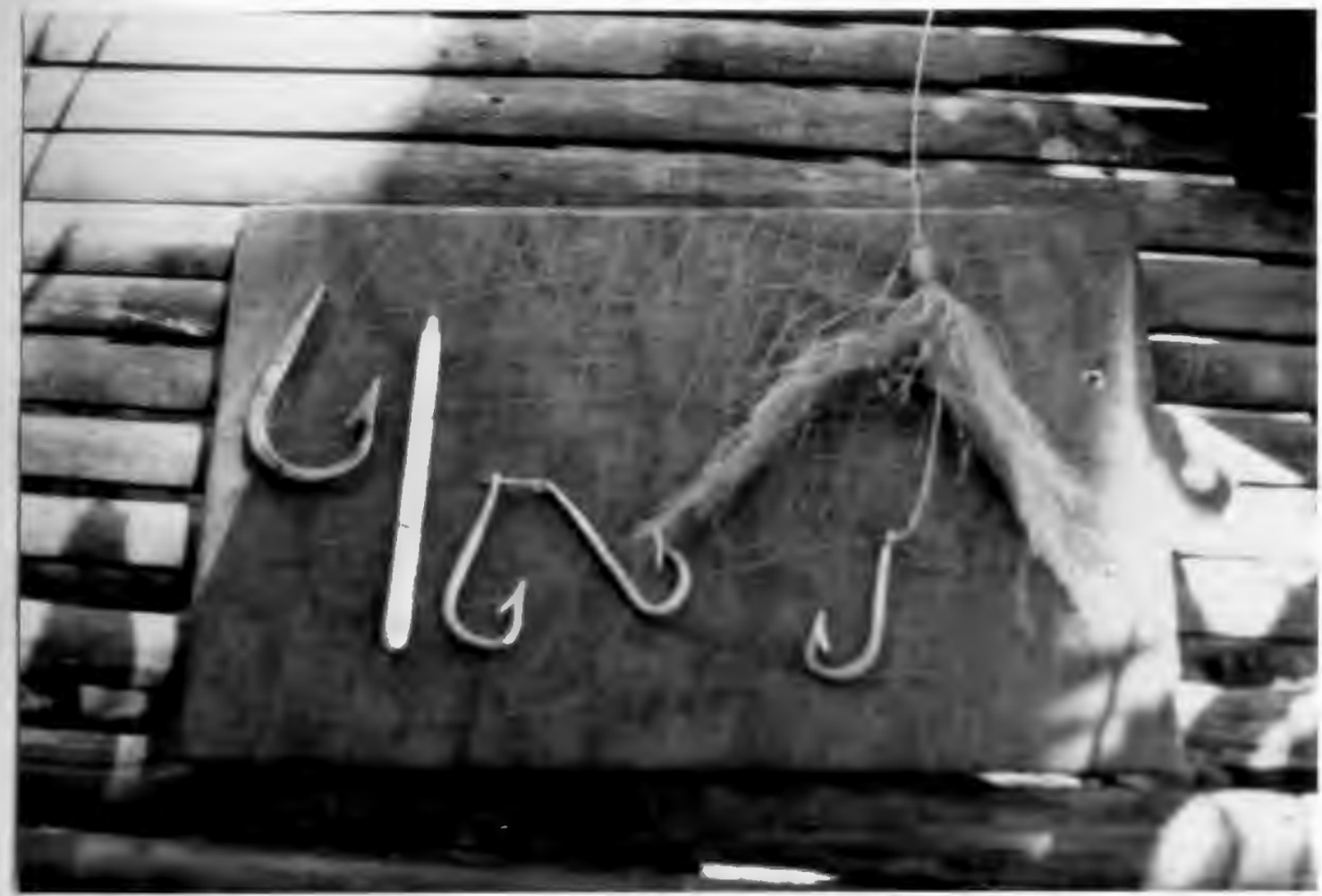

FIGURE I 6

Hand made fishing hooks from stainless steel. 


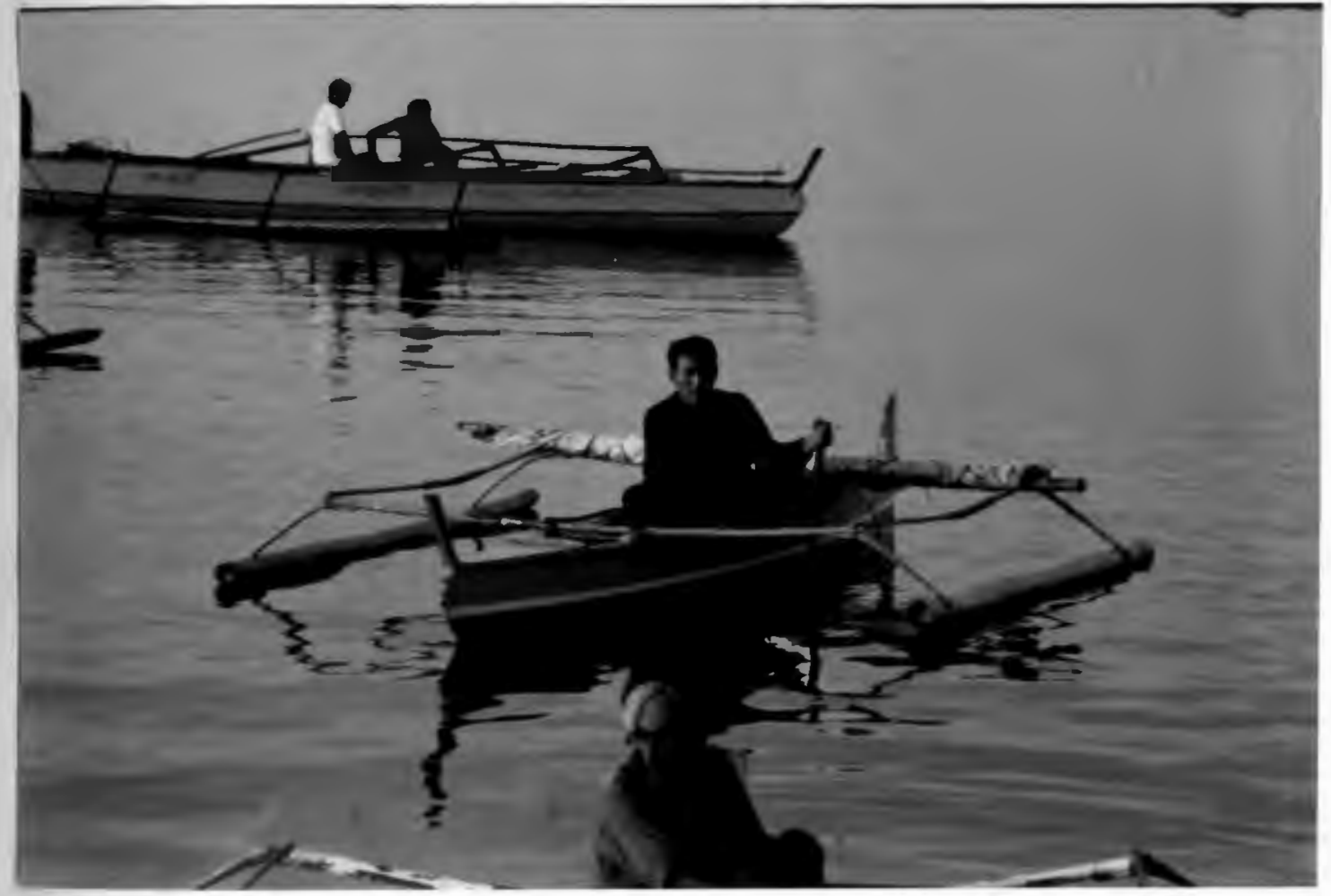

FIGURE I7

Traditional non-motorized banca used for the hookand-line fishermen in Cape Bolinao. 
fishing grounds as long as the biting of fish was good; when the biting was poor they either switched fishing grounds or came back to shore.

(3.6) Catch, effort and catch per unit effort.

The fishing effort of 80.5 line-hour yielded a catch of 176 fish weighing $49.2 \mathrm{kgs}$. The monthly average catch per line-hour (CPUE) was $0.589 \mathrm{kgs}$ (s.d.= 0.187 ) ranging from 0.324 to $0.935 \mathrm{kgs}$ (Fig 18). Figure 19 shows the monthly catch ranging from 2.34 to $12 \mathrm{kgs}$ with an average of $7 \mathrm{kgs}\left(s . \mathrm{d}_{0}=3.6\right)$. The monthly total catch estimates are plotted in Figure 20. The average number of fishing days was 16 (s.d.=1.7); the average number of fishermen per month was 9.75 (s.d.=1.5); and the average fishing hour-day was 5 (s.d.=1.8). Effort, total weight, total number of fish, CPUE, and estimate total catch are given in Table 10. Figures 21 and 22 show the relationship between catch and CPUE versus total effort. A regression analysis of the catch versus the effort is given in figure 23. The monthly number of fish is plotted in Figure 24. Catch per unit effort was calculated for the three most abundant families: Lethrinidae, Lutjanidae, and Serranidae (Fig 25).

\section{(3.7) Catch Composition.}

Sixteen species representing 6 families were collected by the hook-and-line fishery. The family Lethrinidae was the most abundant, comprising 69.88 of the total catch. The families comprising more than 18 
FIGÜRE · 18.

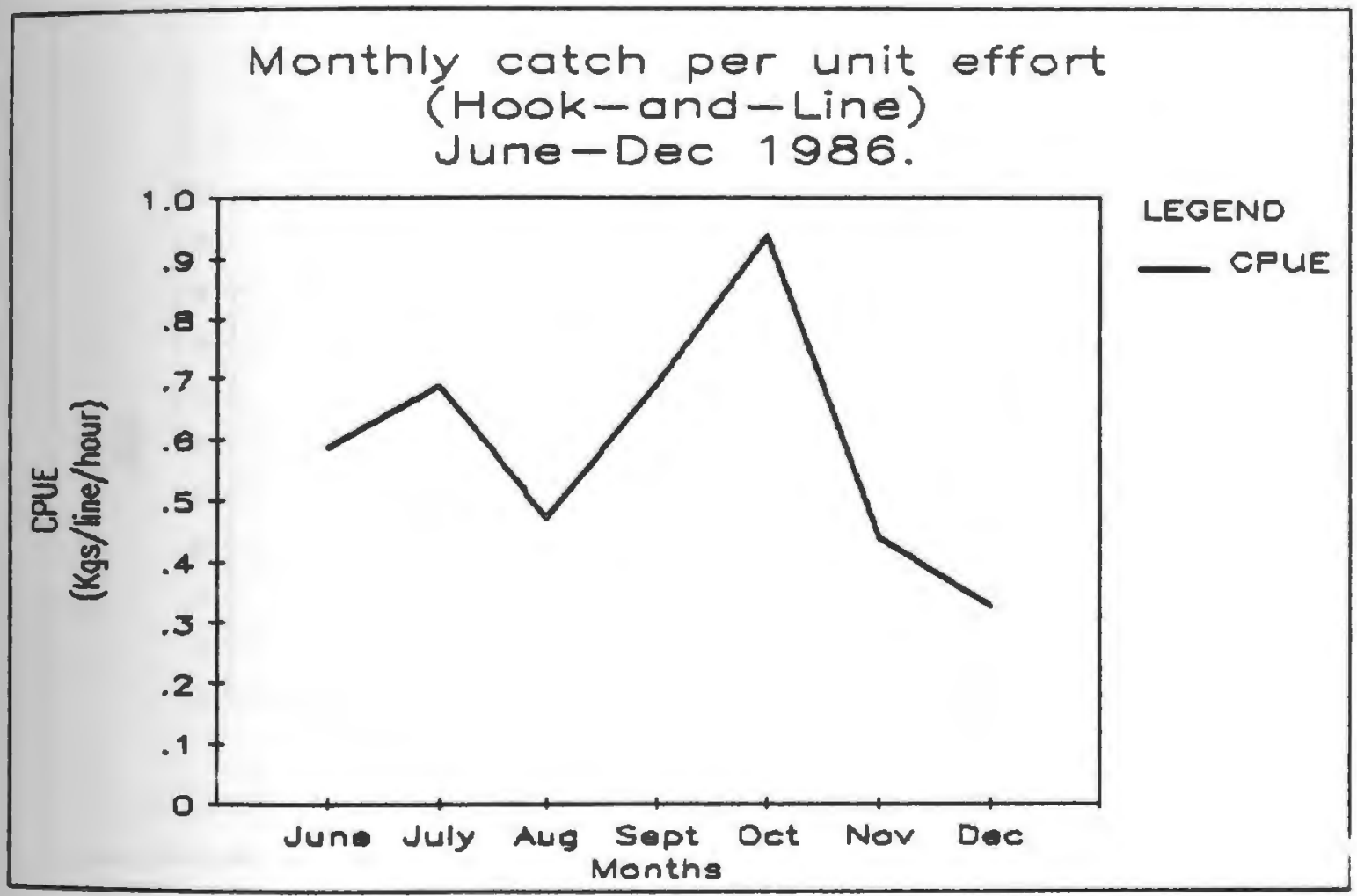


FIGURE 19.

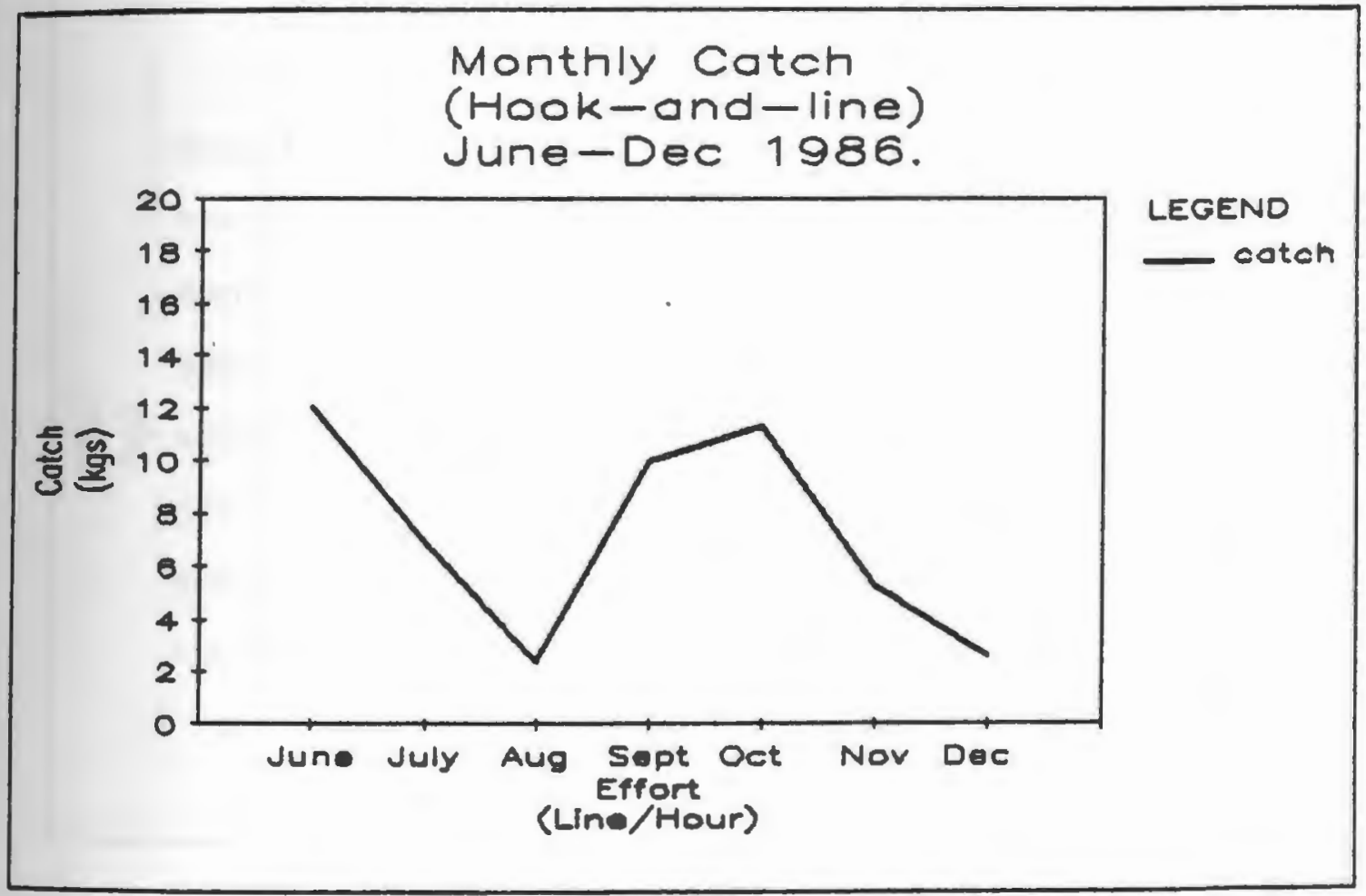


FIGURE 20.

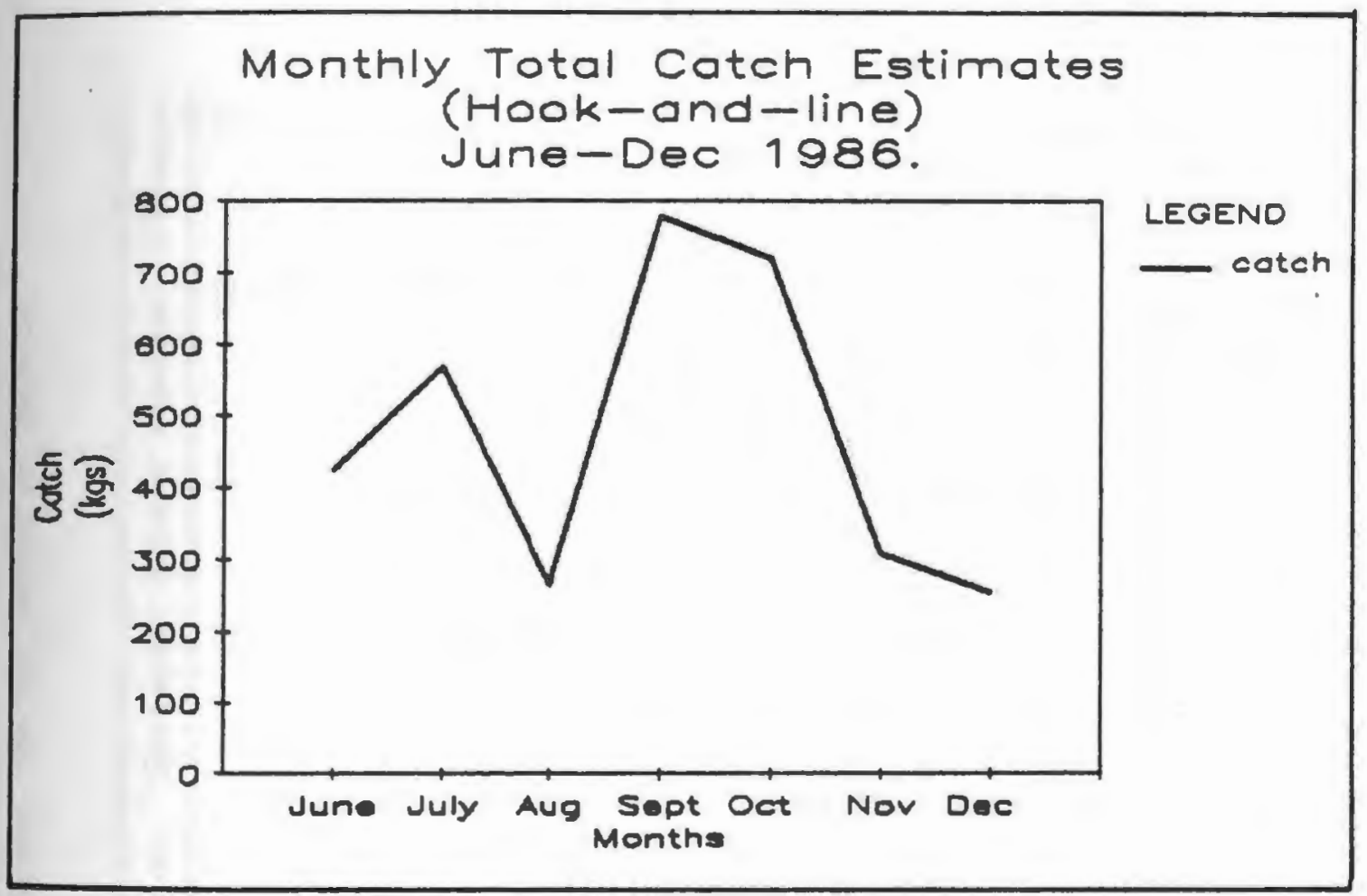


Table 10

Summary of monthly lines catches in the outer edge reef.

Cape Bol inao, Philippines. For the period of June to

Decenber 1986.

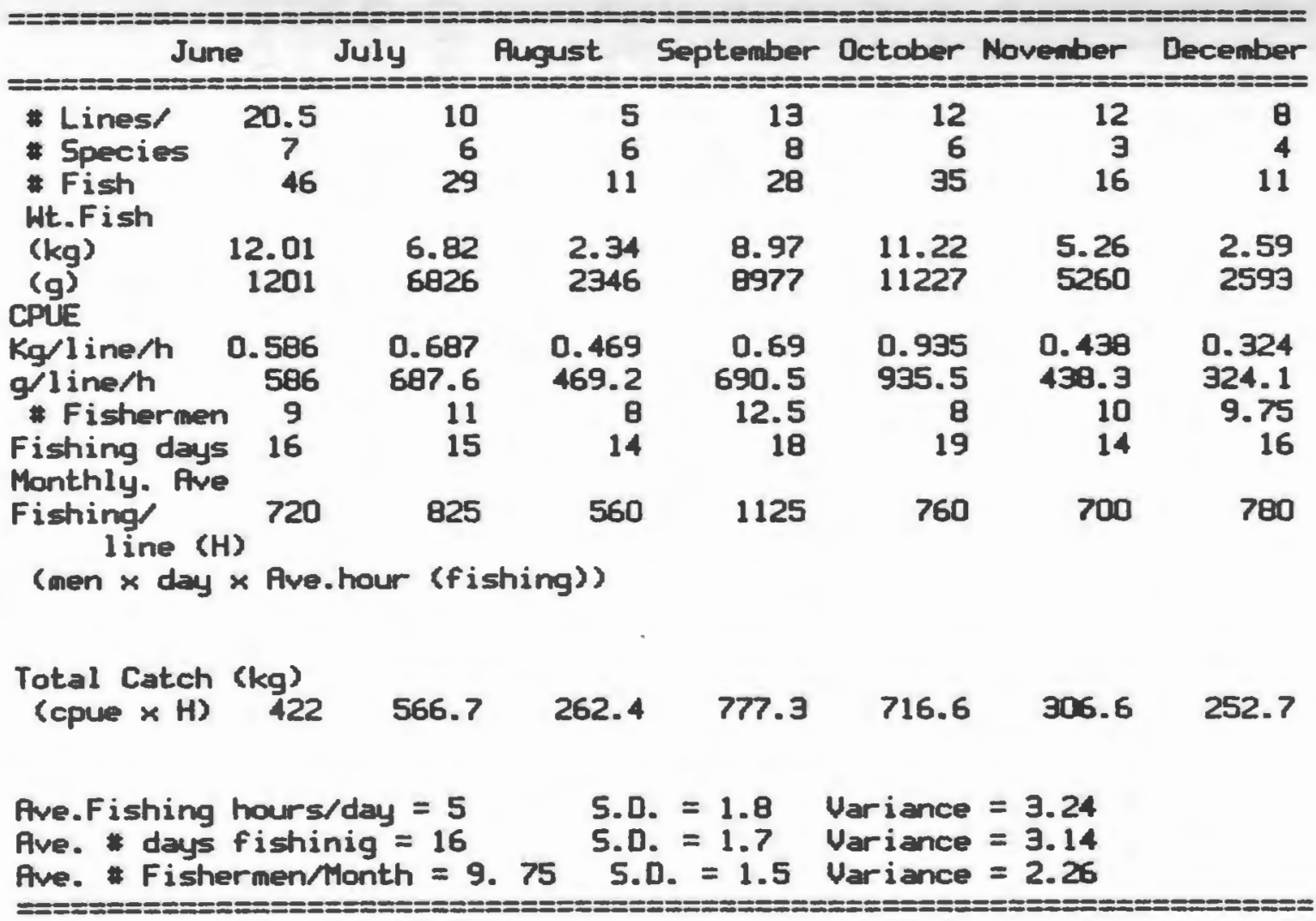




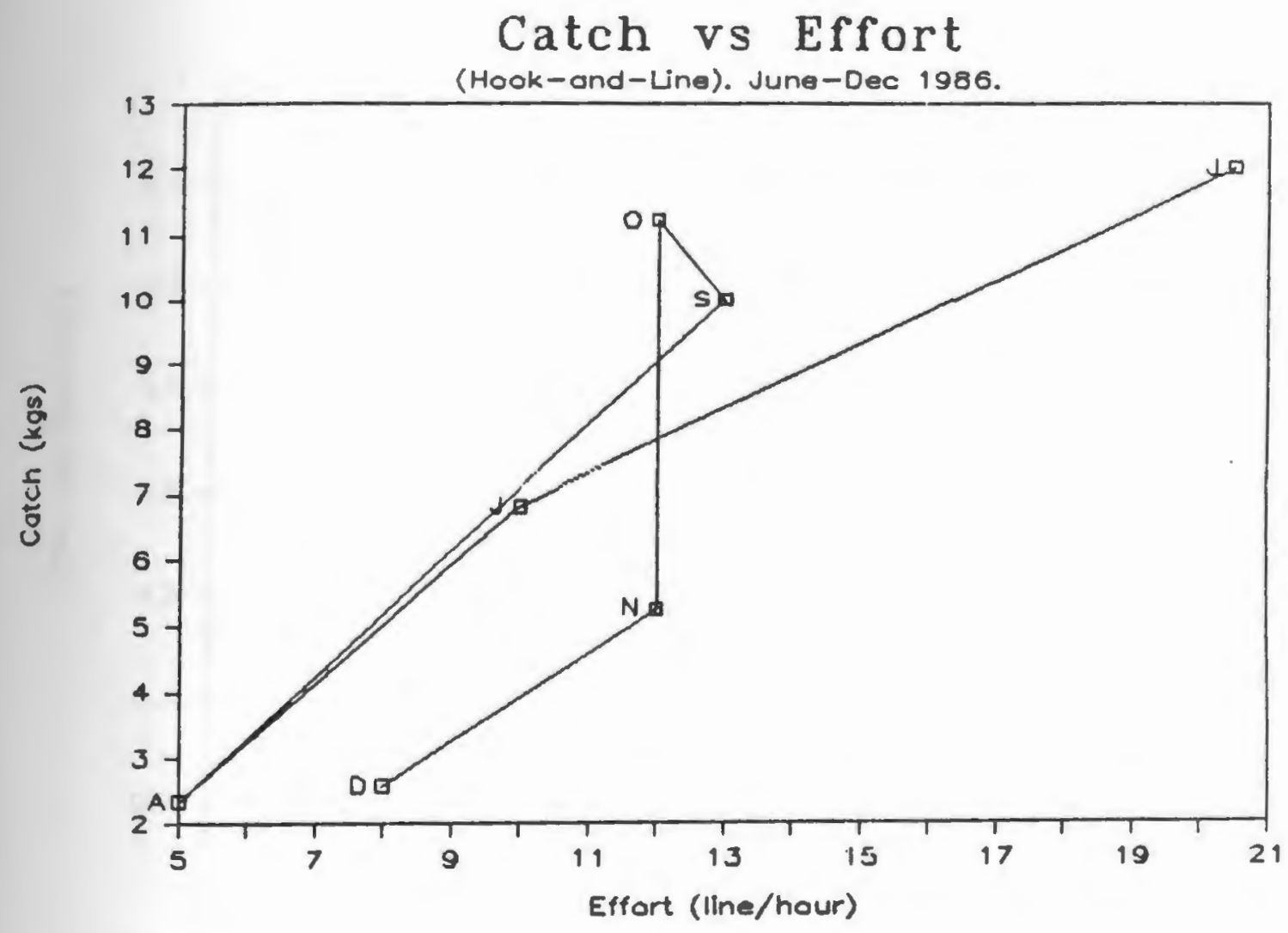

FIGURE 21

Relationship between catch and effort for the hookand-line fishery. The months are represented by the letters: $\mathrm{J}=$ June, $\mathrm{J}=\mathrm{July}, \mathrm{A}=$ August, $\mathrm{S}=$ September, $O=$ October, $N=$ November, $D=$ December. 


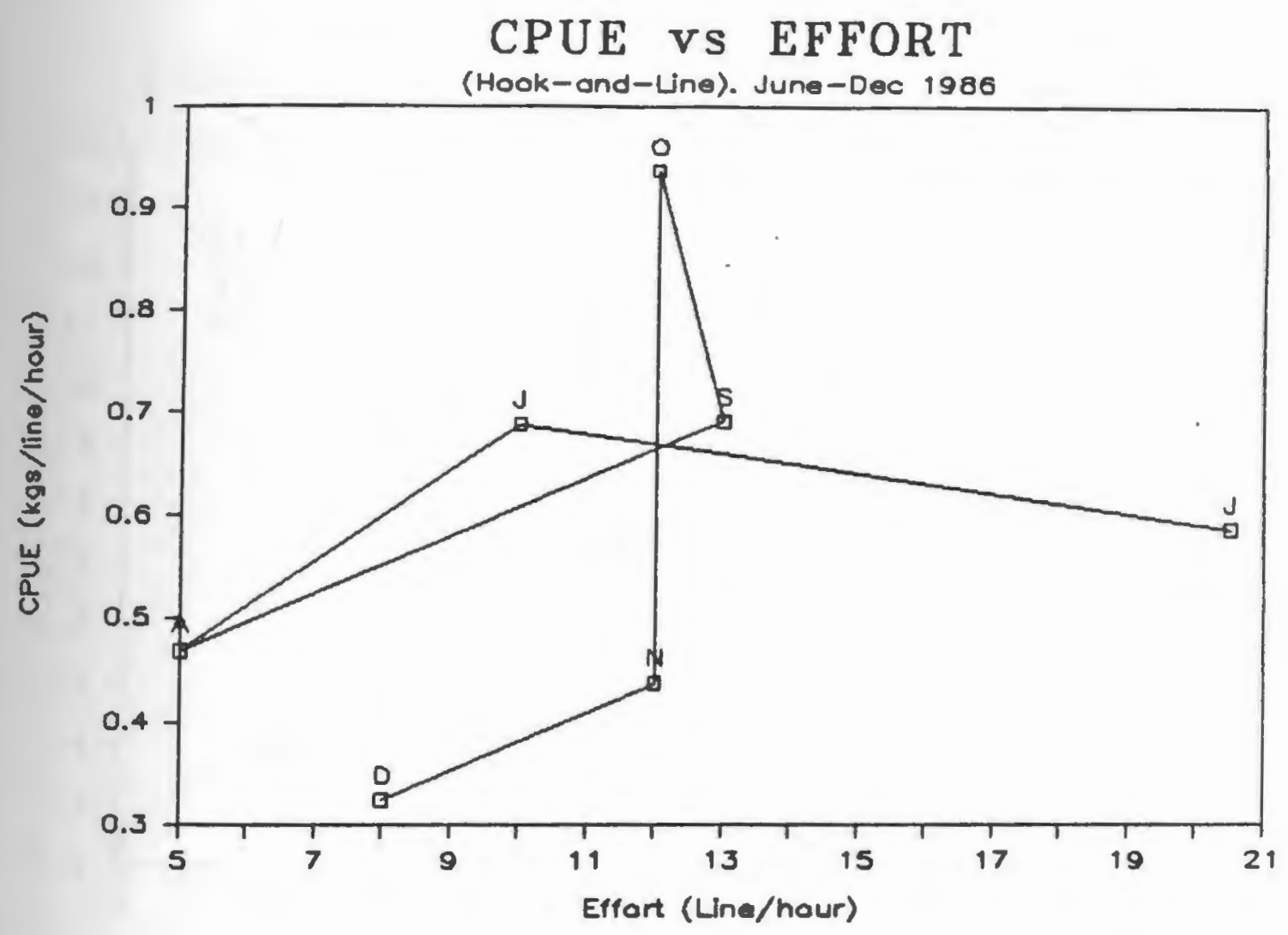

FIGURE 22

Relationship between CPUE and effort for the hookand-1ine fishery. The months are represented by the letters: $\mathrm{J}=$ June, $\mathrm{J}=\mathrm{July}, \mathrm{A}=$ August, $\mathrm{S}=$ September, $\mathrm{O}=$ October, $\mathrm{N}=$ November, $\mathrm{D}=$ December. 
Linear Regression (Effort vs Catch)

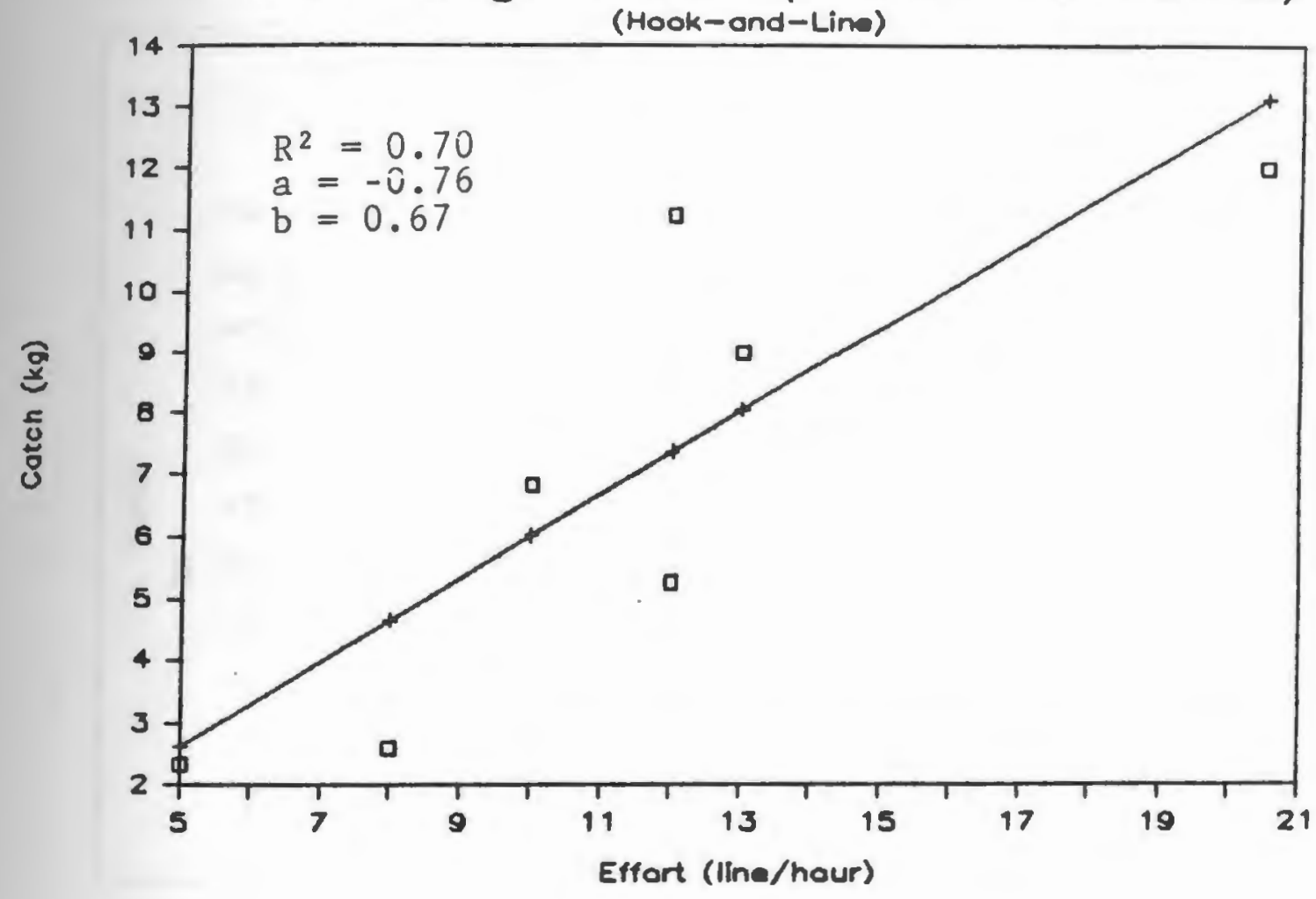

FIGURE 23

Liniar regression between total catch and total effort for the hook-and-Iine fishery. June-December 1986. 
FIGURE 24.

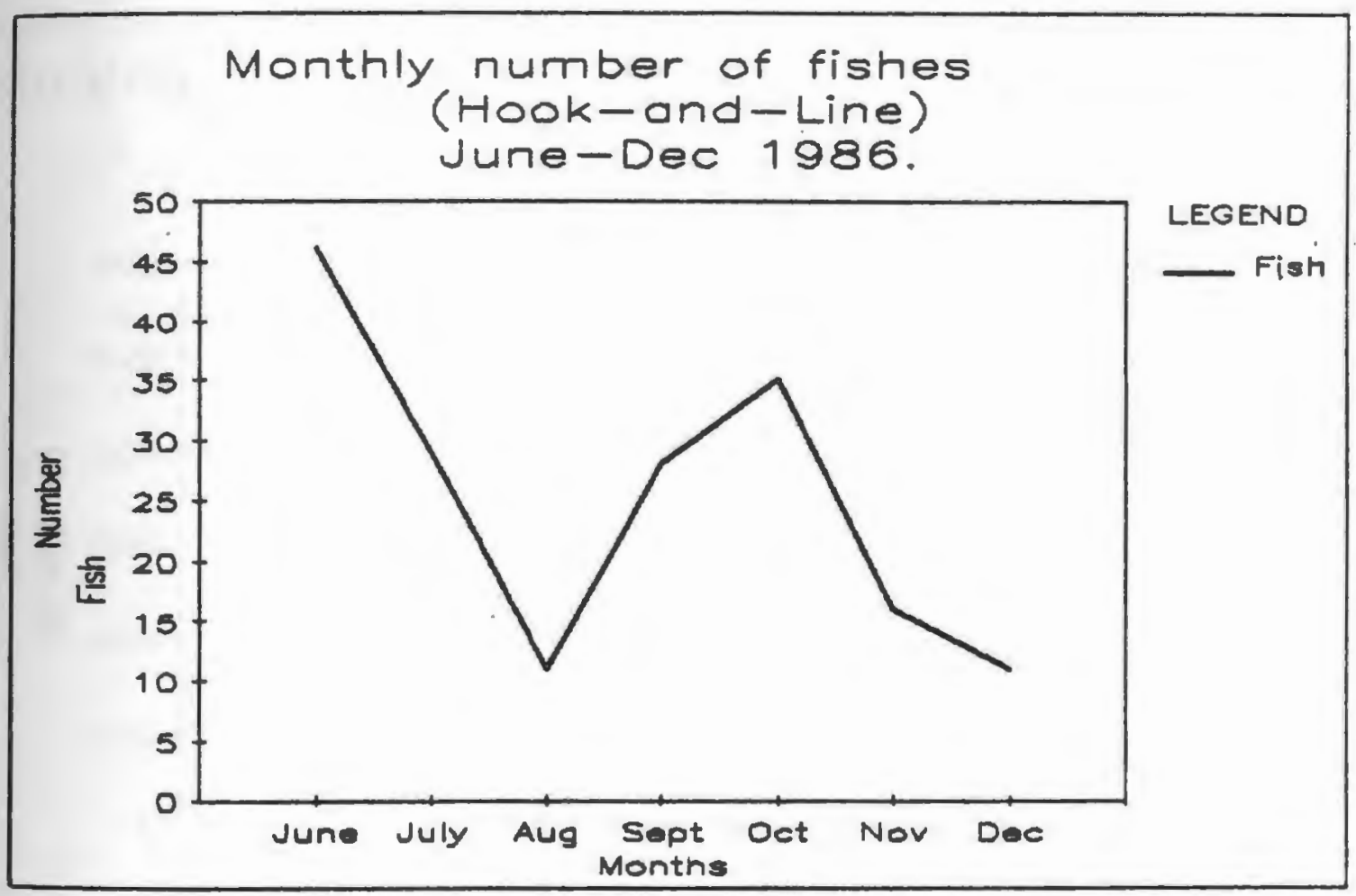


FIGURE 25 .

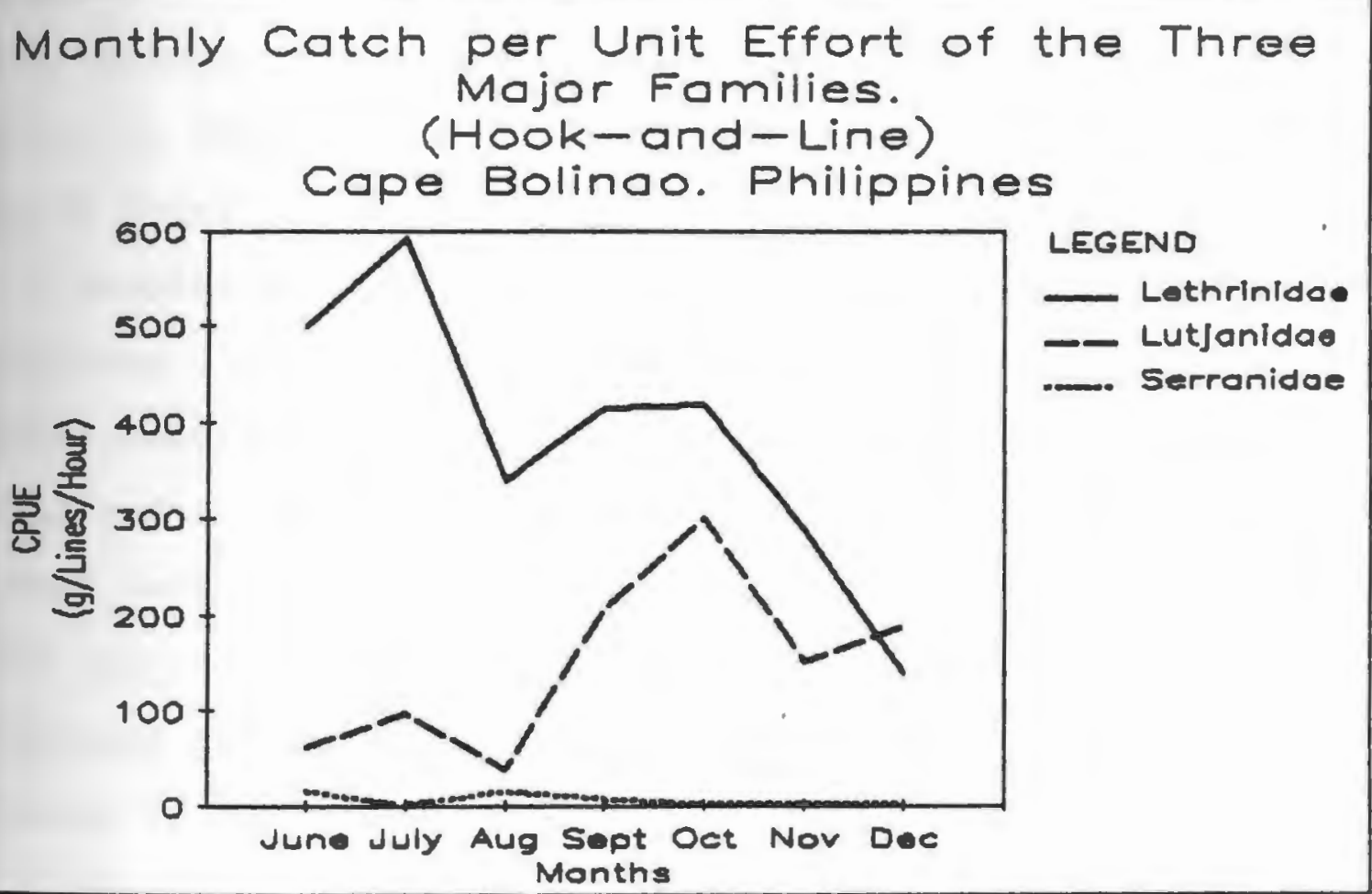


of the total weight and number caught are shown in Table 11. A list of the species composition by number, weight and percentage of total catch is given in Appendix 8. The principal species were Lethrinus variegatus, L. ornatus, L. rhodopterus, Lutjanus fulviflamma, and L. gibbus. These species accounted for 80.38 of the total catch and $83.4 \%$ of the total number. The monthly abundance of the three major families is given in Table 12.

(3.8) Notes on the Biology.

Samples of the five more abundant species were analyzed for length composition and length-weight relationships. The relationships between total length (TL) and standard length (SL), standard length (SL) and total length (TL), and total length (TL) and weight (W) for Lethrinus rhodopterus, L. ornatus, L. variegatus, Lutjanus fulviflamma, and $\underline{L}$. gibbus are summarized in Tables 13 and 14 .

The length frequency distribution and the lengthweight relationship for the five species considered for the hook-and-line fishery are given in Appendix 9 and 10 .

The size composition of Lethrinus rhodopterus ranged from 20.4 to $32.5 \mathrm{~cm}$ with an average of $26.5 \mathrm{~cm}$ (s.d.=0.61). Lethrinus variegatus ranged from 16.6 to

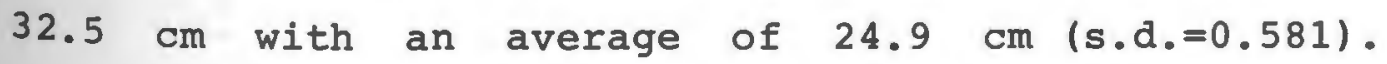
Lethrinus ornatus ranged from 18.7 to $33.2 \mathrm{~cm}$ with a 
Table 11 Species comprising more than 1\% of the weight and number caught for the hook-and-1 ine Fishery Cope Bolinao, Philippines.

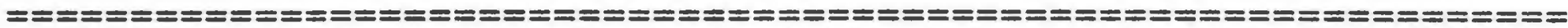
SPECIES $\because$ WE IGHT $\because$ NUMEER

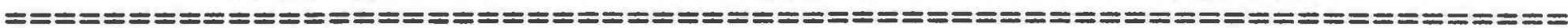

$\begin{array}{lll}\text { Lethrinus variegatws } & 25 & 24.4 \\ \text { Lethrinus rhodopterws } & 23.7 & 21.5 \\ \text { Lethrinus ornatus } & 15.7 & 20.4\end{array}$

Lut $\mathrm{L}$ anus ful $1 \cup$ if 1 amma

Lutjanus 9 ibbus

Gummocran ius

1 ethrinoi des

Pricanthus hamrur

Lutjanus decussatus

Lethrinus lentjan

15.?

17

others

6.1

5.6

5.5

1.7

1. 4

1. 4

3.8

1. 1

0.5

1.7

2. 8

$100 \%$

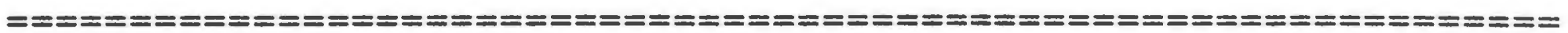


Table 12

Monthly Percent of the three most abundant families for the hook-and-1 ine Fishery. Cape Eol inao, Philippines. For the period of June to December 1986.

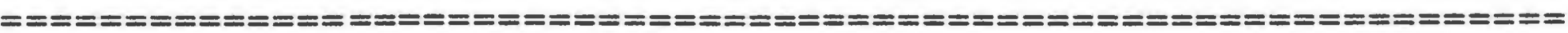

\section{Fami 1 i es}

Month Lethrinidae Lutjanidae Serranidae Dthers

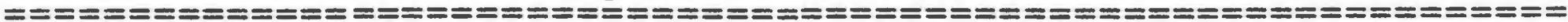

June

82. 98

10.64

6.38

$100 \%$

Jul 니

17.25

August

82.75

18.18

21.43

71.43

45.72

9.09

September

48.57

62.5

375

3.57

November

54.55

45.46

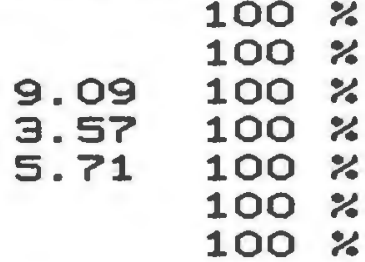

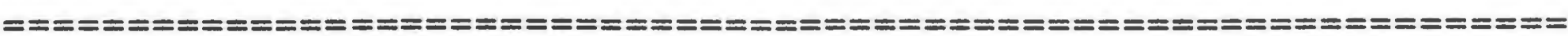


Table 19 Relationship of total length ( $T$ ) to standard length (S) and sstandard length (SL) to total length (TL) for five species from the hoxk-andline Fishery. where $a$ and $b$ are constants.

\begin{tabular}{|c|c|c|c|c|c|c|c|}
\hline SPECIES & $\begin{array}{c}\mathrm{TL}=\mathbf{a}+ \\
\mathbf{a} \\
========\end{array}$ & $==$ & $\begin{array}{c}S L=a+ \\
a \\
=========\end{array}$ & $\begin{array}{l}\text { b } \\
\mathbf{b} \\
\end{array}$ & $\begin{array}{c}5 i z e-R a n g e \\
(\mathrm{~cm})\end{array}$ & $n$ & $r$ \\
\hline $\begin{array}{l}\text { Lethrinus } \\
\text { rhodopterus } \\
\text { variegatus } \\
\text { ornatus }\end{array}$ & $\begin{array}{r}0.251 \\
1.2 \\
-0.423\end{array}$ & $\begin{array}{l}1.21 \\
1.15 \\
1.24\end{array}$ & $\begin{array}{r}0.593 \\
-0.153 \\
9.3\end{array}$ & $\begin{array}{r}0.79 \\
0.82 \\
0.4\end{array}$ & $\begin{array}{l}20-32.5 \\
16-32.5 \\
18-33\end{array}$ & $\begin{array}{l}35 \\
43 \\
36\end{array}$ & $\begin{array}{r}0.96 \\
0.95 \\
0.5\end{array}$ \\
\hline $\begin{array}{l}\text { Lut janus } \\
\text { fulvif lana } \\
\text { gibbus }\end{array}$ & $\begin{array}{r}0.97 \\
-2.48\end{array}$ & $\begin{array}{l}0.82 \\
1.35\end{array}$ & $\begin{array}{r}-4.24 \\
1.95\end{array}$ & $\begin{array}{l}0.94 \\
0.73\end{array}$ & $\begin{array}{l}20-30 \\
16-40\end{array}$ & $\begin{array}{l}30 \\
10\end{array}$ & $\begin{array}{l}0.78 \\
0.99\end{array}$ \\
\hline
\end{tabular}


Table 14 Relationship of Total Length (TL) to weight (W) for five species from the hook-and-line fishery In where $a$ and $b$ are constants.

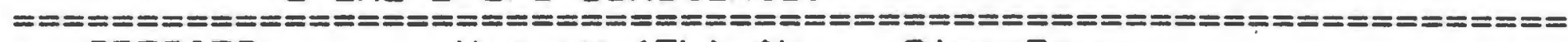
SPECIES $\mathbf{W}=$ $a x(T L)$ Si ze-Range (cm) n

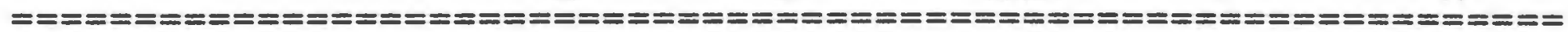
Lethrinus rhodopterus

0.006 var i egatus

0. 013 ornatus

0. 307

$\begin{array}{ll}3.25 & 20-32.5 \\ 3.06 & 16-32.5\end{array}$

0.012 fulviflamma

0.023

3.06

$20-30$ 9 ibbus

2.87

$16-40$

0.98

0.99

0.77

38

43

36

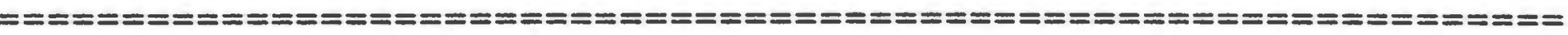


average of $22.7 \mathrm{~cm}(\mathrm{s.d} .=0.435)$. Lutjanus fulviflamma ranged from 19.8 to $30.1 \mathrm{~cm}$ with an average of $25.4 \mathrm{~cm}$ (s.d.=0.530). Lutjanus gibbus ranged from 16.8 to 39.9 $\mathrm{cm}$ with an average of $25.4 \mathrm{~cm}(\mathrm{s.d.}=2.33)$.

(3.9) Description of the Spear Fishery.

Spearfishing occurs at night and it is mainly a one species fishery for (Siganus sp. rabbitfishes). The fishing grounds for the spear fishermen are the southeast and northeast of silaki and the northeast and east of Binabalian (Fig 1). There are approximately eight (8) motorized bancas which are engaged in spearfishing. There are also some single raft operators.

Spearfishing in Binabalian is not an activity which allows easy income earning to the unskilled or impoverished fishermen. Spearfishing is one of the most prosperous and competitive fisheries in Binabalian. The gear needed is quite sophisticated for such a smallscale fishery. The equipment used is a gasoline (Petromax) lamp with a modified gas tank, a stainless steel lamp shade to reflect the light, a slimp spear, goggles, fins and small bamboo raft with a basket to carry the lamp and the catch. The goggles have wooden frames, carved by hand, which hold pieces of ordinary glass. The frame is joined together by a piece of rubber band. The goggles are slipped over the head and secured by a single rubber band (Figures 26 and 27). 


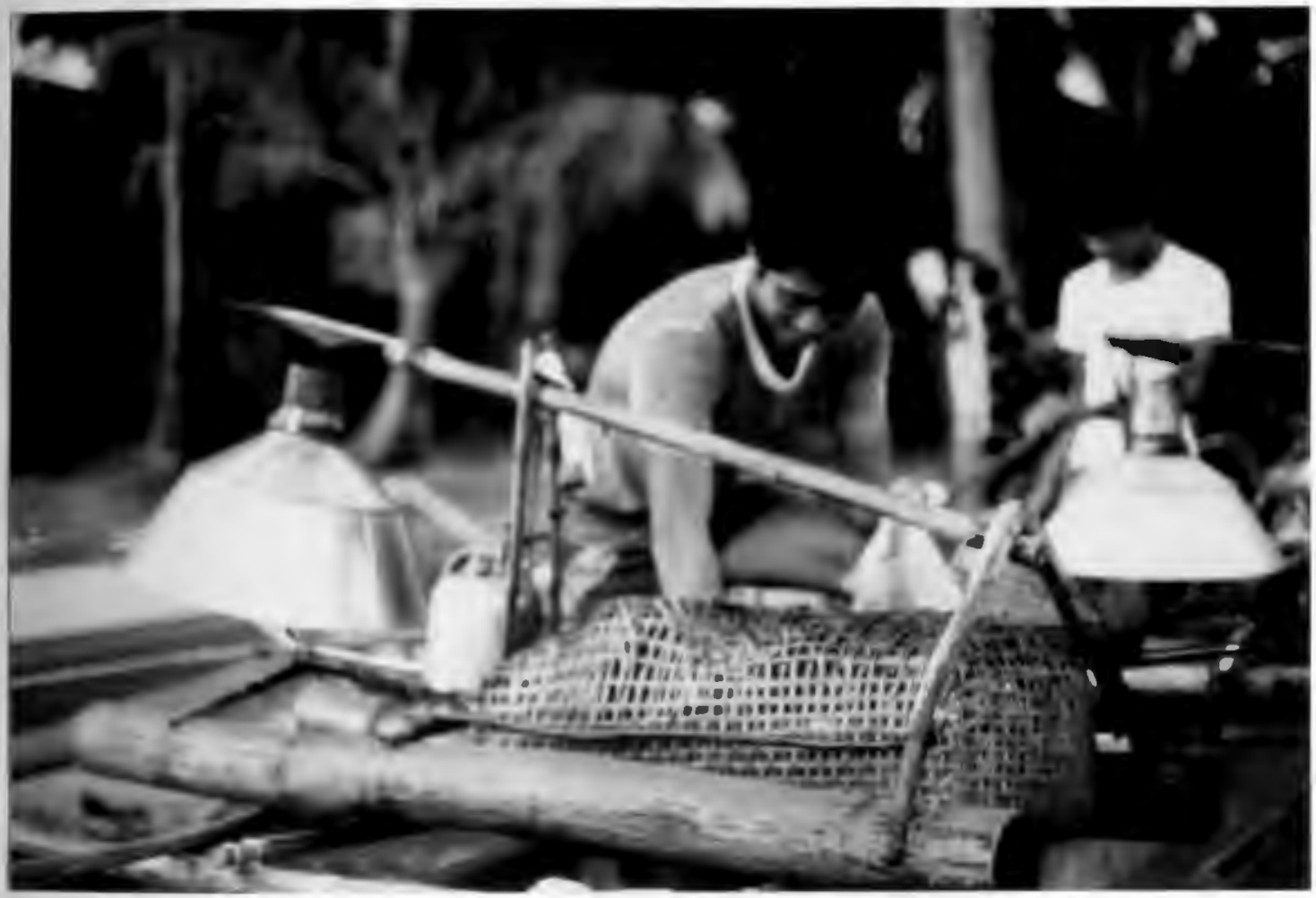

\section{FIGURE 26}

Fishing lamp use in the spear fishery with a modified gas tank and stainless steel lamp shade. 


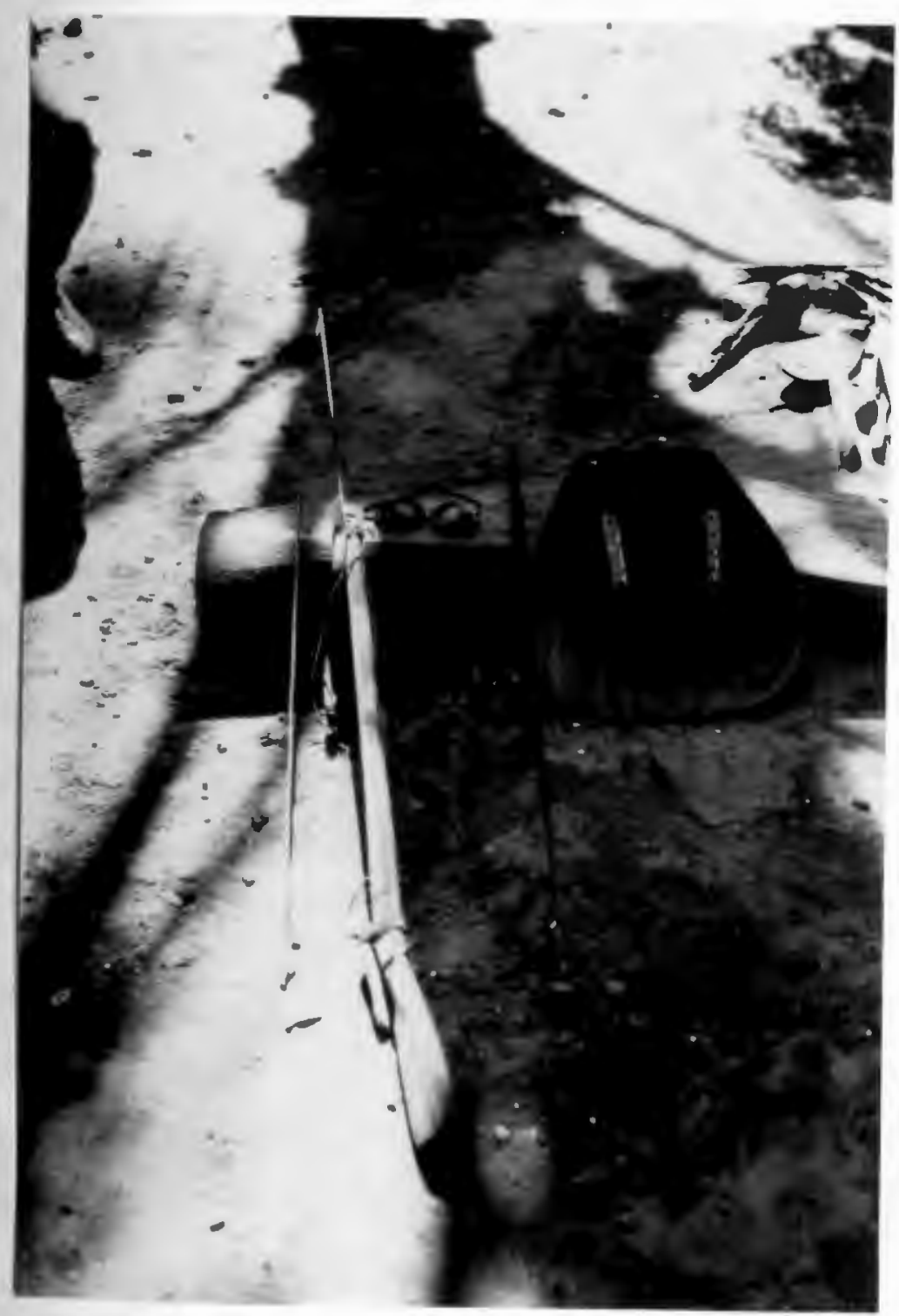

FIGURE 27

Fishing gear use for the spear fishermen, wooden goggles spear gun and wooden flippers. 
The operation usually starts at midnight and ends at daybreak. In the case of a full moon night it will start just after the moon disappears. All bancas are at the beach; the fishermen arrive at the beach and start getting ready to go fishing. The lamps are lit and the rest of the gear is checked before going to sea. Fishermen cannot afford to have problems with the lamp or other part of the gear. There are about five fishermen (s.d.=1.03) per boat and five boats out per night (s.d.=0.832). The owner will go the fishing grounds, but the selection of the fishing spot will be decided by all fishermen.

When the fishermen are ready to go into the water, a small candle is lit in the boat and each man goes into the water. At this time the lagoon looks like a big highway with all the lights moving around. The lamp is pulled as the fishermen swim along. They dive and search around the seagrasses until they spot the fish and spear it. To find the fish in the seagrass requires good vision and a good knowledge of the ecosystem. The researcher was not able to see a fish before it was speared.

The target species are Siganus species due to their reaction to the light. Siganus species expose their dorsal side when they are under a bright light, allowing an easy target for the fishermen. When the sun starts to rise all the fishermen get together in the 
boat and head back to the village. Spearfishing is a very physical activity, fishermen spend an average of 3 hours $\left(s . d_{.}=1\right)$ swimming and diving, sometimes in very windy waters. But at the same time spearfishing brings a high return per fishermen. In a normal night a fishermen can bring 1 to $3 \mathrm{kgs}$ of fish (s.d.=0.035) depending of the season.

Systems for sharing the catch are also simple. Each fishermen saves his own fish. The owner of the boat received 3 pesos/kg from each fisherman and they have the obligation to sell the fish to the wife or mother of the owner of the boat. She acts as the middleman. There is a certain degree of kinship between the spear fishermen in a crew. It is normal to find father, son and relatives fishing together from the same banca. (3.10) Catch, effort and catch per unit effort.

The fishing effort of 72.5 spear-hours yielded a catch of 2136 fishes weighing $94.2 \mathrm{kgs}$. The monthly average catch per spear-hour CPUE was $1,33 \mathrm{~kg} / \mathrm{men}-\mathrm{hour}$ (s.d.=0.352) ranging from 2 in June to 0.9 in August (Fig 28). The monthly catch ranged from $6.78 \mathrm{kgs}$ in September to $19.03 \mathrm{kgs}$ in June with an average of 13.4 kgs (s.d.=4.11) (Fig 29). The monthly total catch estimates are represented in Figure 30. The average number of fishing days per month was 23 (s.d.o=3.65). The monthly number of fish is given in Figure 31. Effort, total weight, total number of fish, CPUE, and 
FIGURE 28.

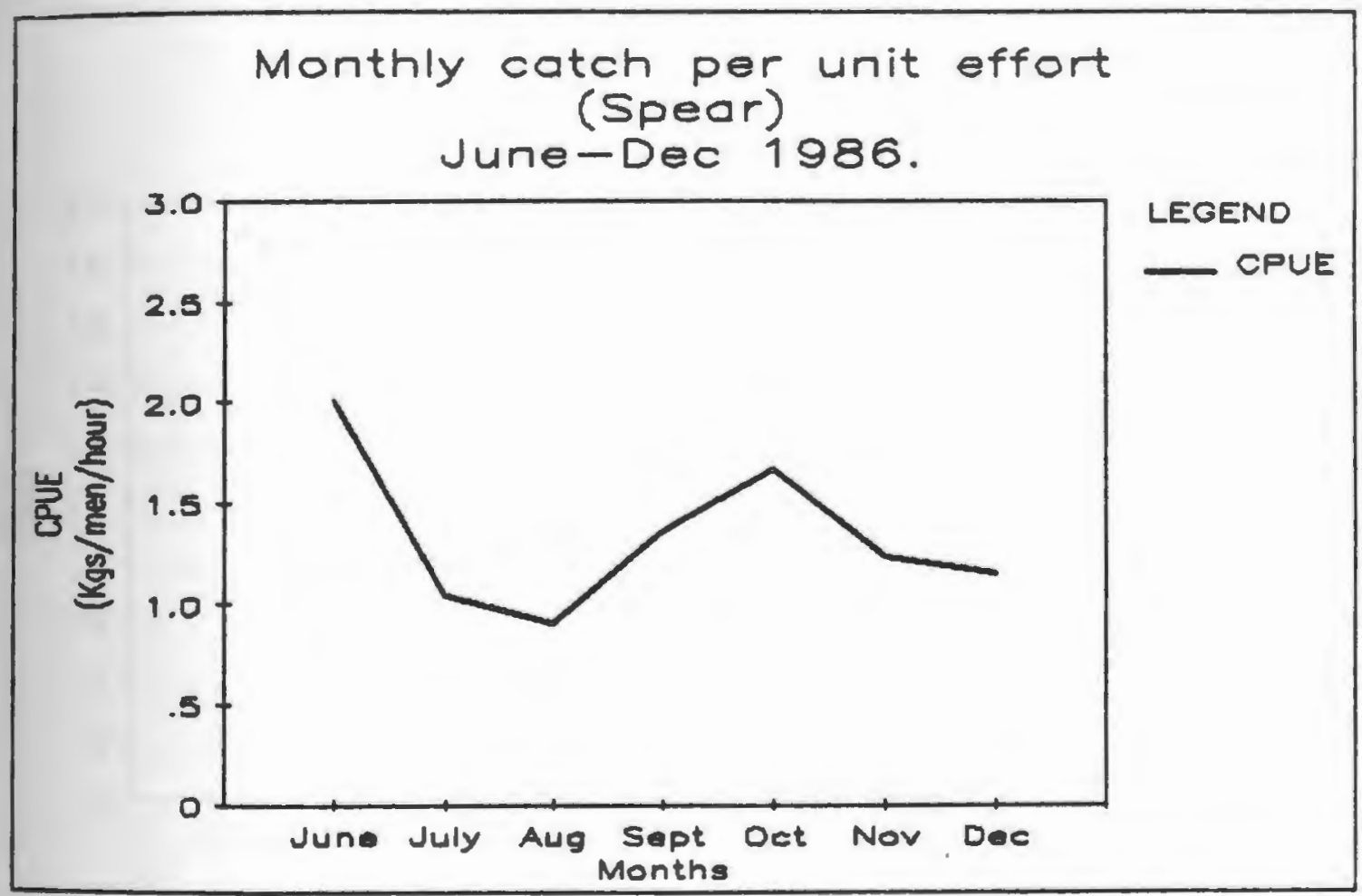


FIGURE 29.

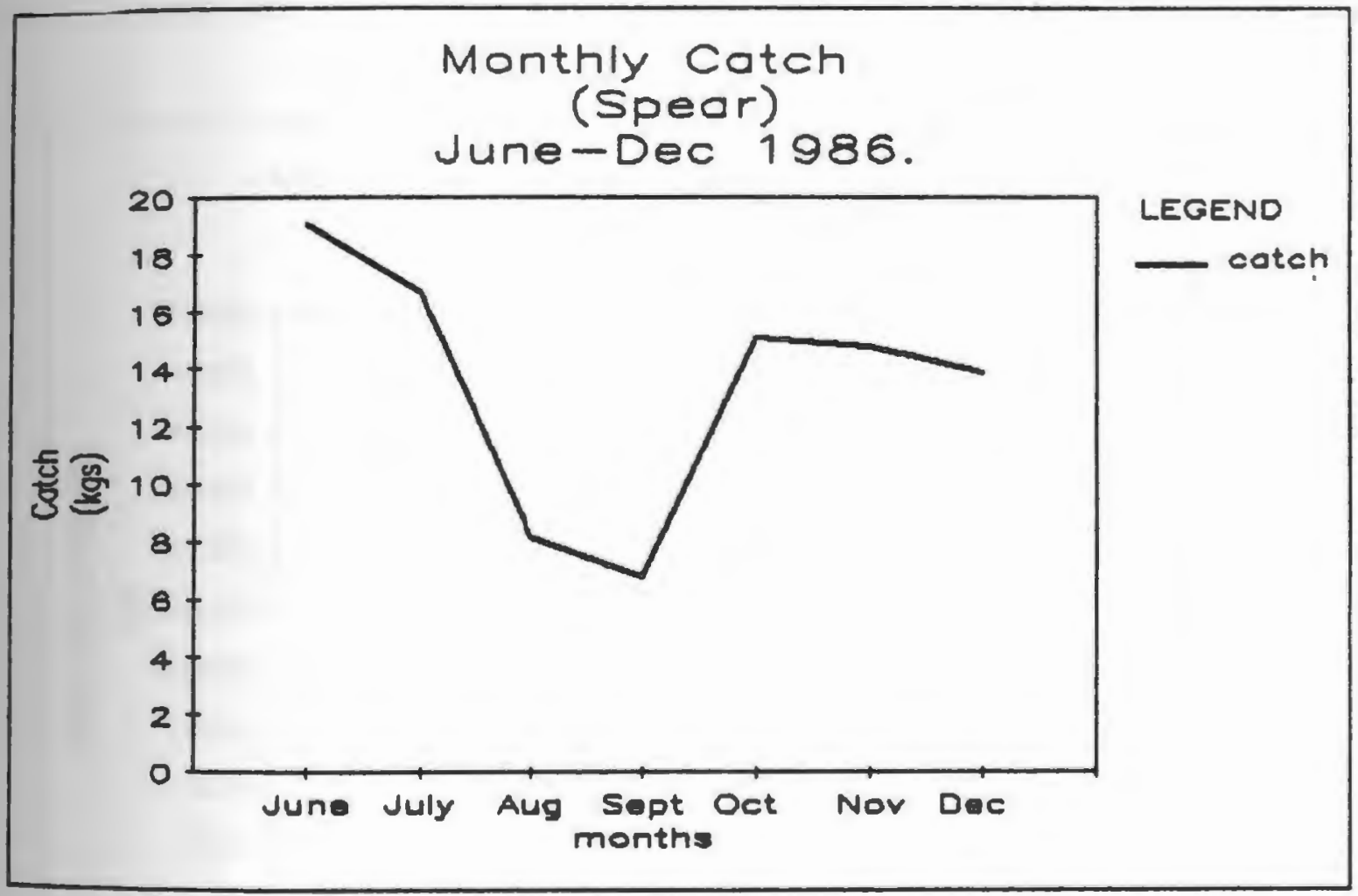


FIGURE 30.

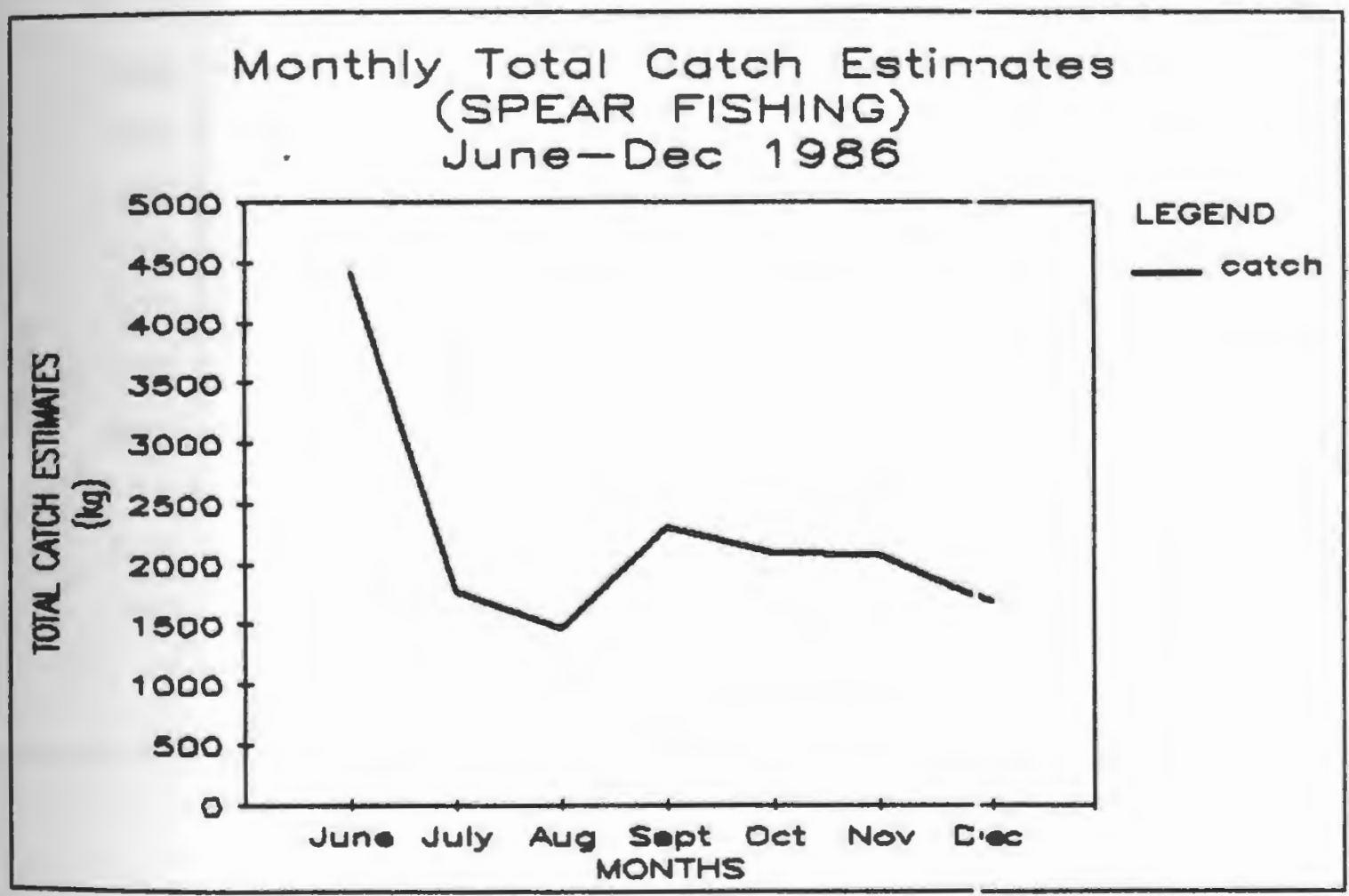


FIGURE 31.

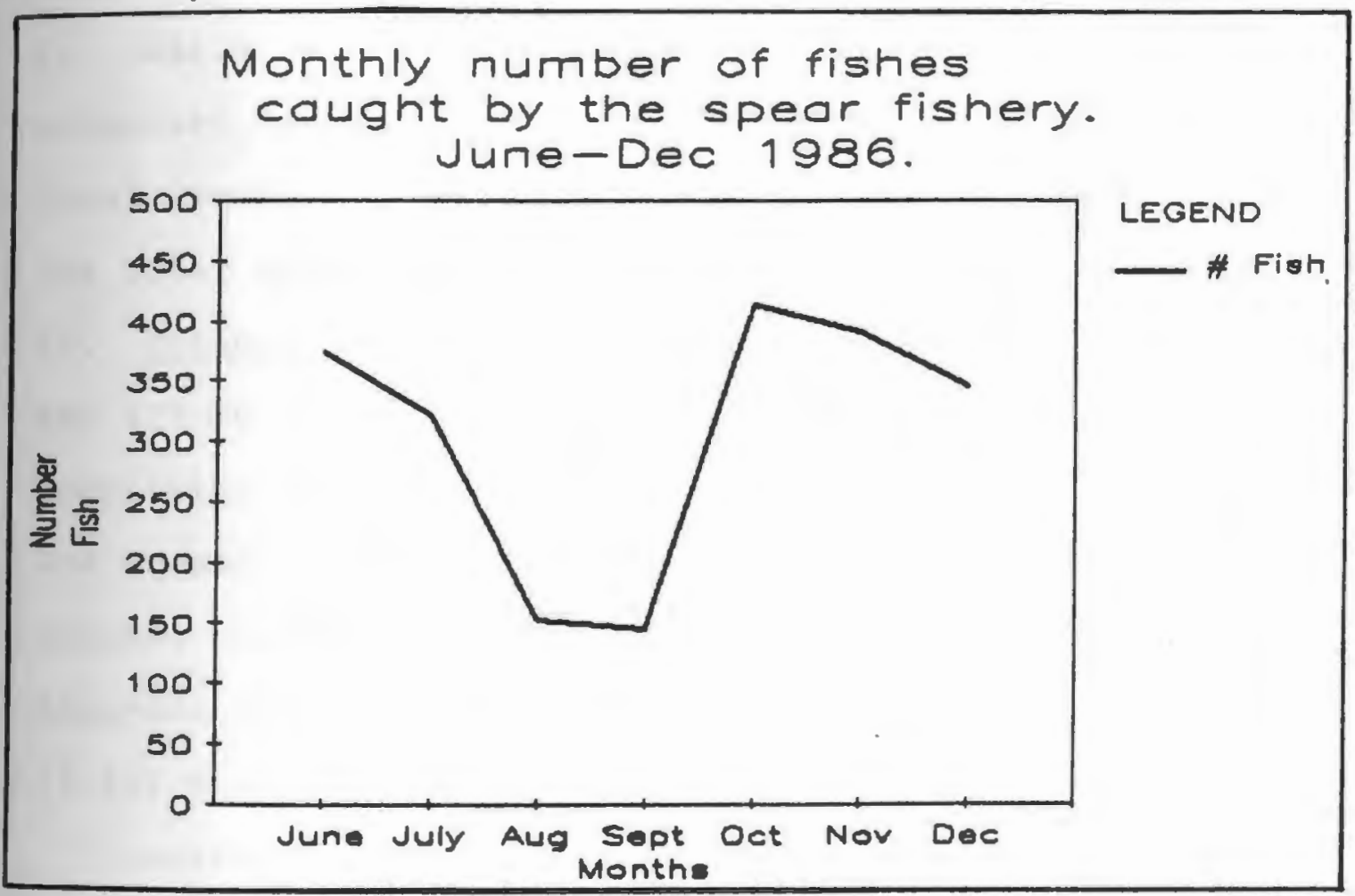


estimated total catch are given in Table 15. Figures 32 and 33 show the relationship between catch and CPUE versus total effort. A regression analysis of the catch versus the effort is shown in Figure 34.

(3.11) Catch Composition.

As mentioned before spear fishing in Cape Bolinao is mainly a one-species fishery. The family Siganidae accounted for $83.7 \%$ of the total catch and $88.7 \%$ of the total number. The families comprising more than 18 of the total weight and number caught are shown in Table 16. Siganus canaliculatus accounted for $82 \%$ by weight and $87 \%$ by number. Table 17 gives a list of the species comprising more than 18 of the total catch by weight and number. A list of the species composition by number, weight and relative abundance is given in Appendix 11.

\section{(3.12) Notes on the Biology}

Monthly samples of Siganus canaliculatus, and total samples of Gnatholepis puntang, Siganus guttatus, and Mulloidichthy falvolineatus were analyzed for length composition and length-weight relationships. The relationships of total length (TL) to standard length (SL), and standard length to total length for the above mentioned species is given in Table 18. The relationship between total length (TL) and weight (W) is given in Table 19. Slope values for monthly samples of Siganus canaliculatus were tested for statistical 
Table 15

Sumary of monthly Spear Catches in a Coral Reef Lagoon Cape Bolinao. Philippines. For the Period of June to December 1986.

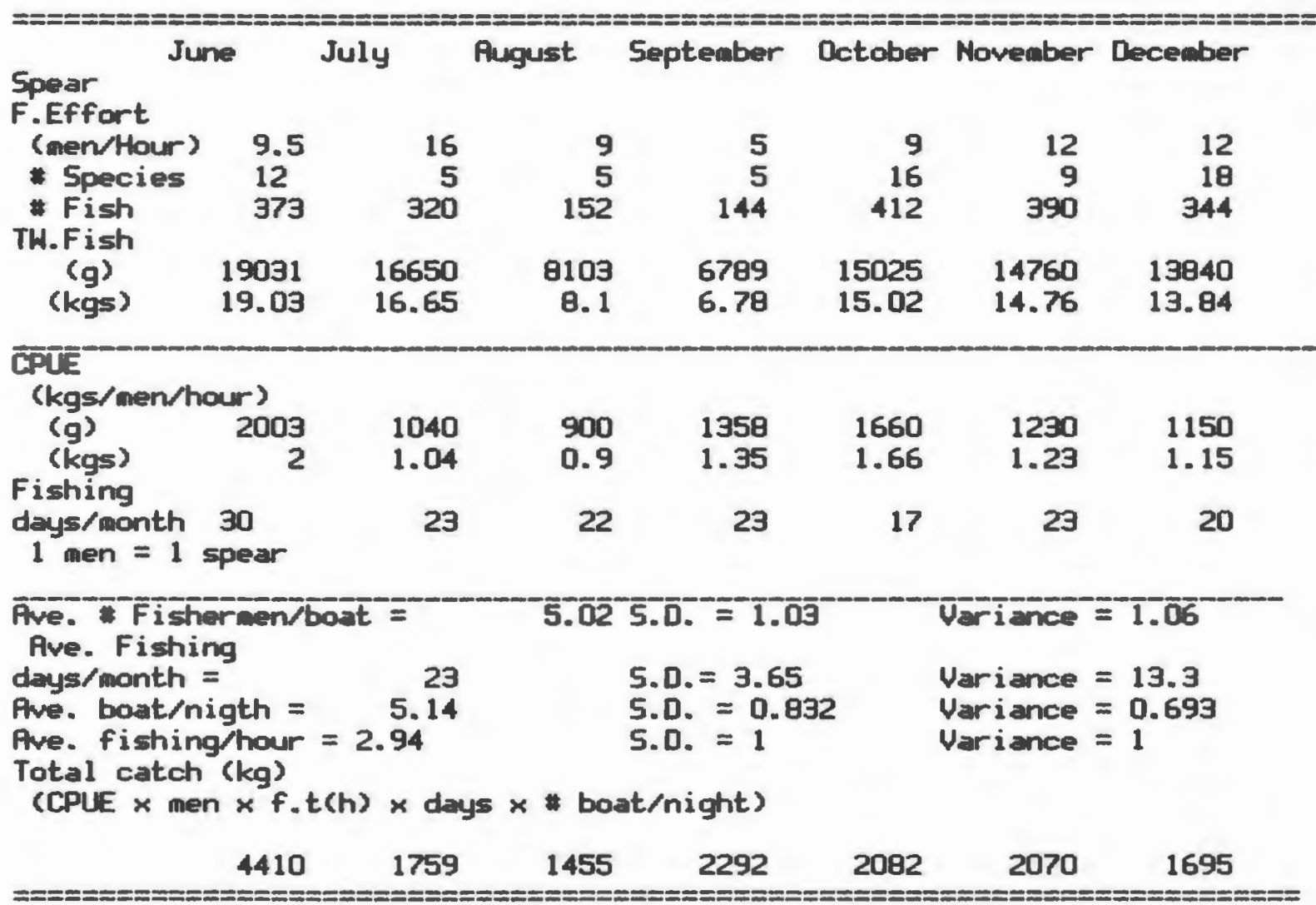


Catch vs Effort

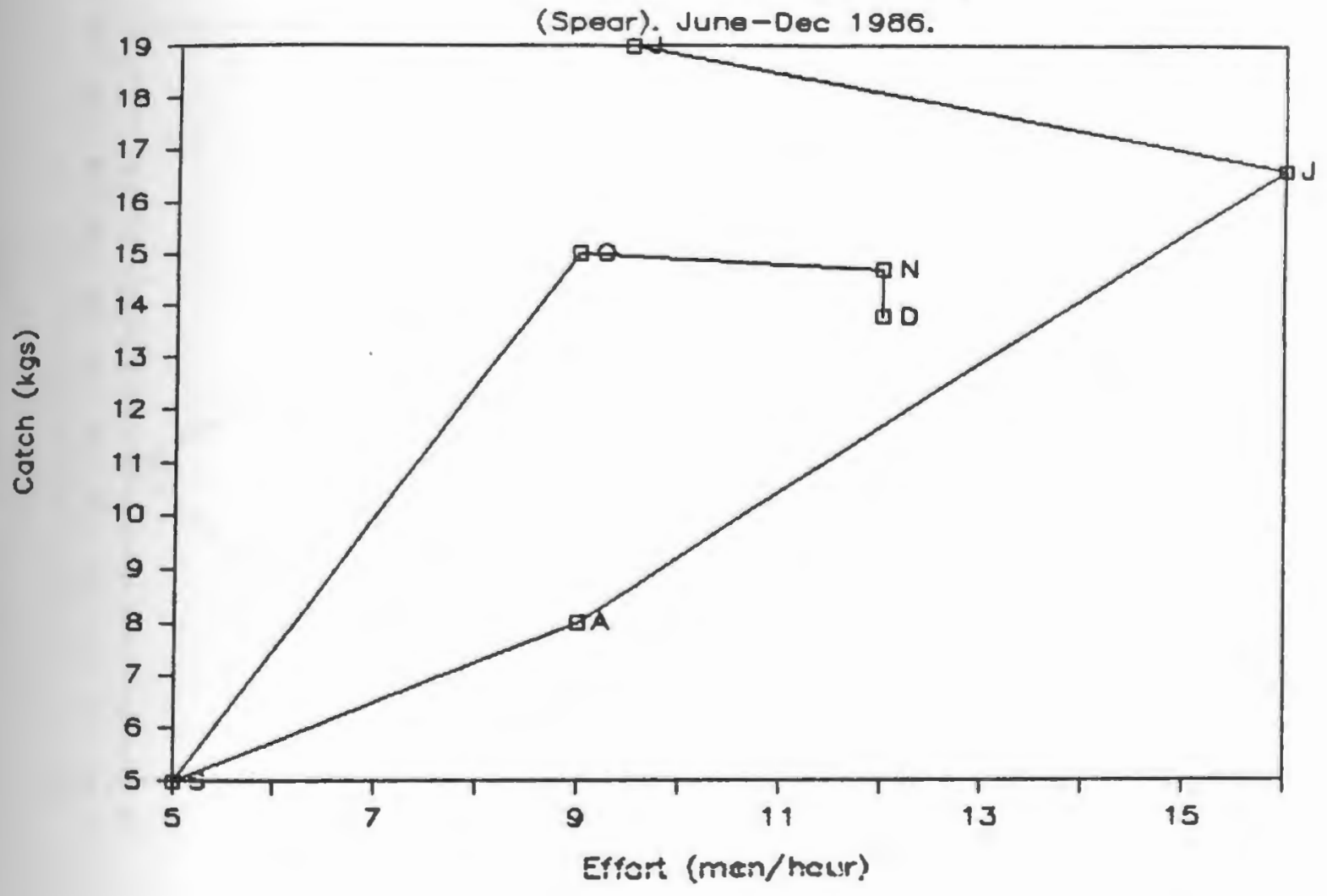

FIGURE 32 .

Relationship between total cath and total effort for the spear fishery. June-December 1986. 


\section{CPUE vs Effort}

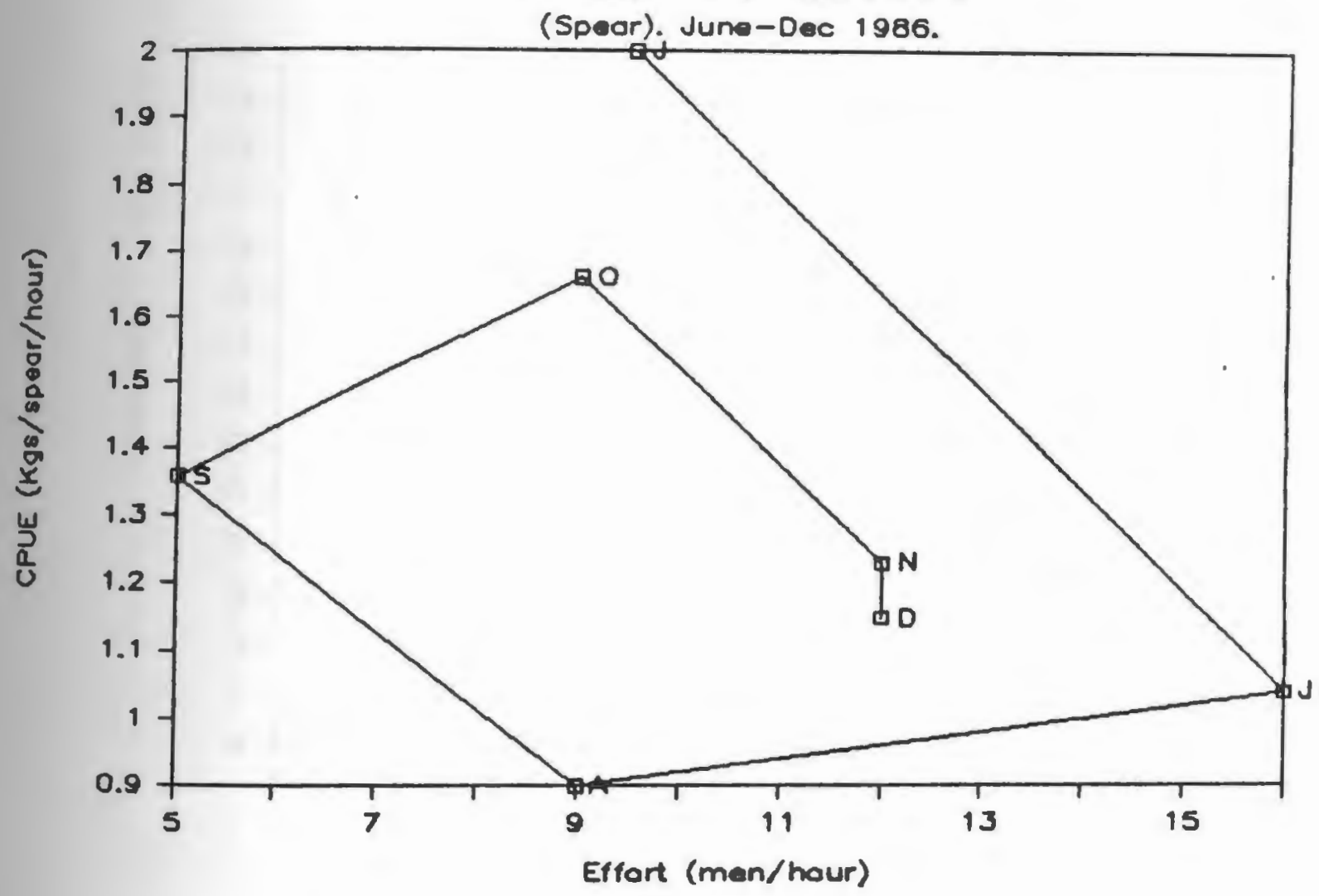

\section{FIGURE 33}

Relationship between CPUE and total effort for the spear fishery. June-December 1986. 
Linear Regression

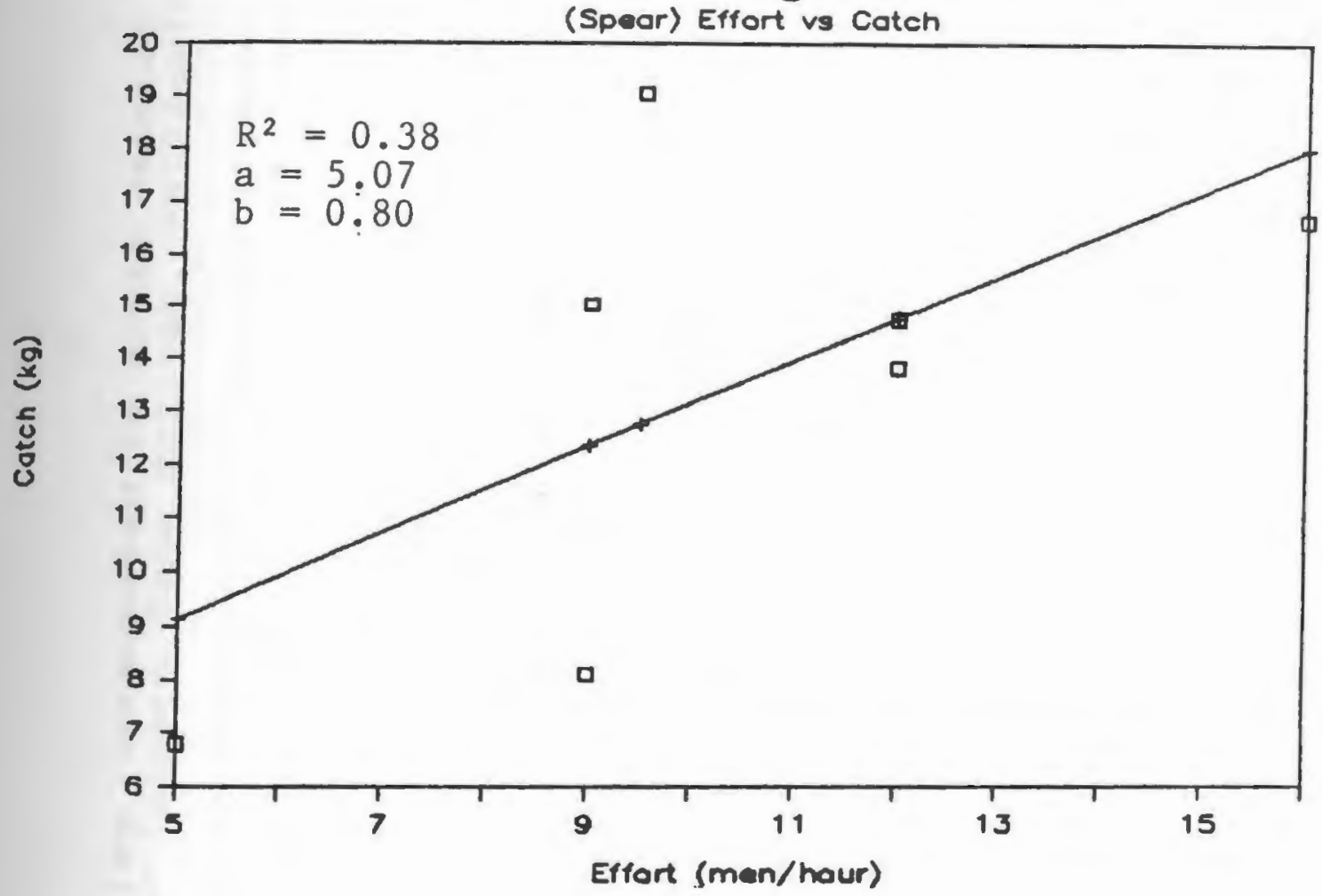

FIGURE 34

Liniar regression between total catch and total effort for the spear fishery. Cape Bolinao. JuneDecember 1986. 
Table 16

Major familios reprosentod in spear catches in
a coral roef lagoon. Cape Bolinag, philippines.

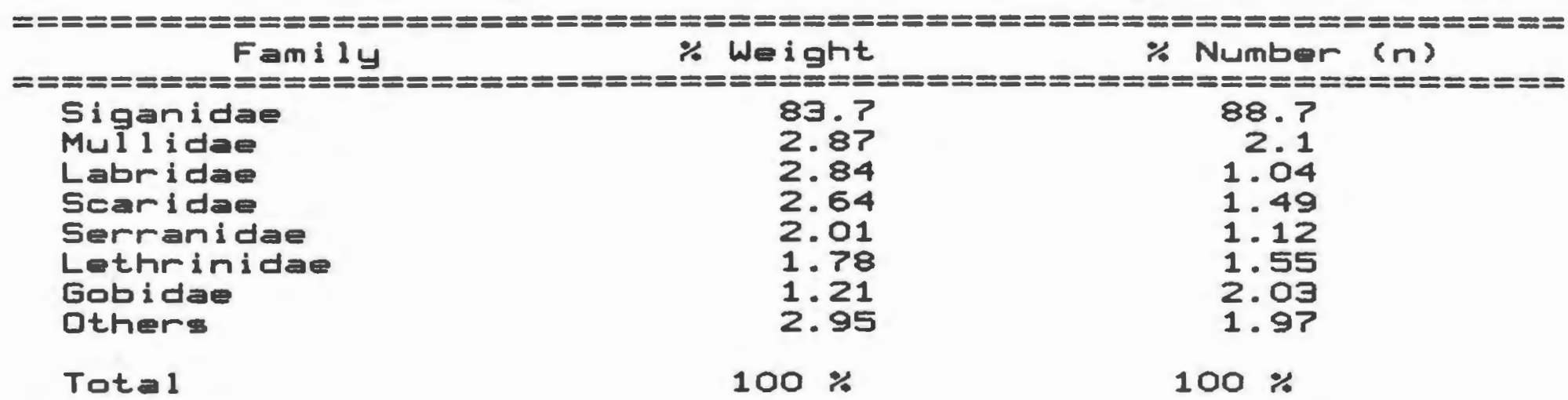

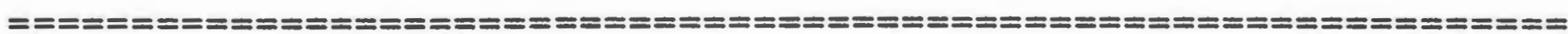


Table 17 Species comprising more than 1\% of the weight and number caught for the spear fishery. Cape Bolinao, Phi lippines.

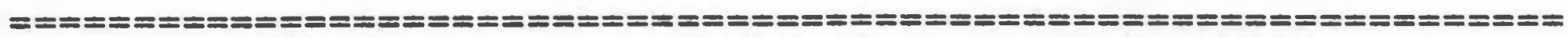
SPECIES $\%$ WEIGHT $\%$ NUMEER

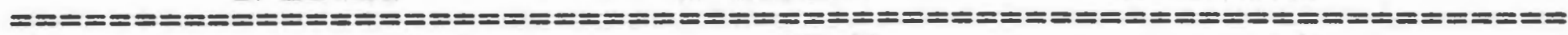
Siganws canaliculatus 82.5

Enatholepis puntang

Siganus guttatus

Chaerodon anchorago

1.2

1.6

1.9

1. 73

Mulloidichthys

faluol ineatus

Scarus sp.

other species

$1 \cdot 5$

1.5

9.8

$100 \%$

1.07

0.74

1.02

0.74

?.?

$100 \%$

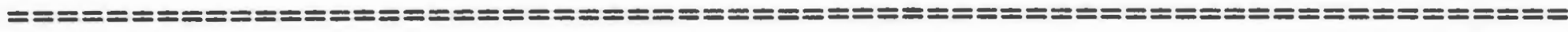


Table 18 Relationship of total length (TL), standard length (SL) and standard length (SL) to total length (TL) for five species from the spear Fishery where $a$ and $b$ are consttants.

\begin{tabular}{|c|c|c|c|c|c|c|c|}
\hline SPECIES & $\begin{array}{rl}T L & a+b(S) \\
a & b\end{array}$ & & $S L=a+b(T L)$ & & $\begin{array}{c}\text { Size-Range } \\
\text { (cm) }\end{array}$ & n & $r$ \\
\hline \multicolumn{8}{|l|}{ Siganus } \\
\hline $\begin{array}{l}\text { canal iculatus } \\
\text { guttatus } \\
\text { Mul loidichthys }\end{array}$ & $\begin{array}{l}0.99 \\
0.34\end{array}$ & $\begin{array}{l}1.13 \\
1.19\end{array}$ & $\begin{array}{l}- \text { min. } 37 \\
- \text { mil. } 25\end{array}$ & $\begin{array}{l}0.84 \\
0.83\end{array}$ & $\begin{array}{l}8-22.2 \\
11.4-21\end{array}$ & $\begin{array}{r}355 \\
23\end{array}$ & $\begin{array}{l}0.96 \\
0.99\end{array}$ \\
\hline $\begin{array}{l}\text { falvol ineatus } \\
\text { Goatholepis }\end{array}$ & -0.08 & 1.25 & in. 16 & 0.79 & $12-20$ & 22 & 0.99 \\
\hline puntang & -0.55 & 1.41 & 2.29 & 0.57 & $11 . \theta-15$. & 37 & 0.8 \\
\hline
\end{tabular}


Table 19 Relationship of total length (TL) to weight (W) for $-$ four species from the spear fishery.

\begin{tabular}{|c|c|c|c|c|c|}
\hline SPECIES & $w=\underset{a}{a x}(T L)$ & b & $\begin{array}{c}5 \text { i ze }-R \text { minge } \\
(\mathrm{cm})\end{array}$ & r & n \\
\hline 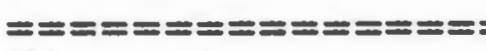 & 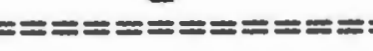 & $=====$ & 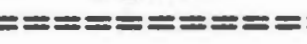 & $====$ & $===$ \\
\hline Siganus & & & & & \\
\hline $\begin{array}{l}\text { Canaliculatus } \\
\text { guttatus } \\
\text { Mulioidichthys }\end{array}$ & $\begin{array}{r}-0.009 \\
-0.01\end{array}$ & $\begin{array}{l}3.09 \\
3.14\end{array}$ & $\begin{array}{l}8-22 \cdot 2 \\
11 \cdot 4-22\end{array}$ & $\begin{array}{l}0.97 \\
0.99\end{array}$ & $\begin{array}{r}355 \\
23\end{array}$ \\
\hline $\begin{array}{l}\text { falvoli inatus } \\
\text { Gnatholepis }\end{array}$ & -0.02 & 2.66 & $12-20$ & 0.96 & 22 \\
\hline puntang & -0.07 & 2.19 & $12-15.5$ & 0.87 & 37 \\
\hline
\end{tabular}

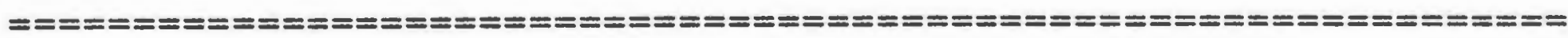


uniformity by the construction of 958 confidence intervals (Fig 35).

The length frequency distribution and the length-weight relationship are given in Appendices 12 and 13 .

Siganus canaliculatus

S. canaliculatus, ranging from $8 \mathrm{~cm}$ to $22.2 \mathrm{~cm}$ with an average size of $14.6 \mathrm{~cm} \quad\left(s . d_{0}=0.625\right)$. The results from the statistical test between the monthly slopes showed no significant difference $(P>0.05)$. Monthly size composition and monthly length-weight relationship for

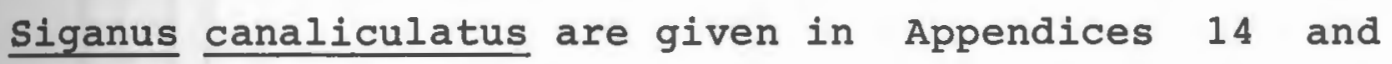
15.

The size of Gnatholepis. puntang ranged from 11.8 to $15.5 \mathrm{~cm}$ with an average of $13.9 \mathrm{~cm}(\mathrm{~s} . d .=0.167)$.

The lengths os Siganus guttatus ranged from 11 to $21.5 \mathrm{~cm}$ with an average of $14.3 \mathrm{~cm}$ (s.d.=0.729).

Mulloidichthys falvolineatus ranging from 12 to 20 $\mathrm{cm}$ with an average of 18.2 (s.d.=0.359).

(3.13) Fish Yield.

The area of the fringing reef to the $15-\mathrm{m}$ isobath is about $9.06 \mathrm{sq} \mathrm{km}$ (Fig 1). An estimated total of 22.251 tons of fish were caugth by traps, spear and hook-and-line from June to December 1986 in the study area, the estimated fish yield for the three small-scale coral reef fisheries is $2.46 \mathrm{mt} / \mathrm{sq} \mathrm{km}$ during the rainy season. Assuming that there is no 


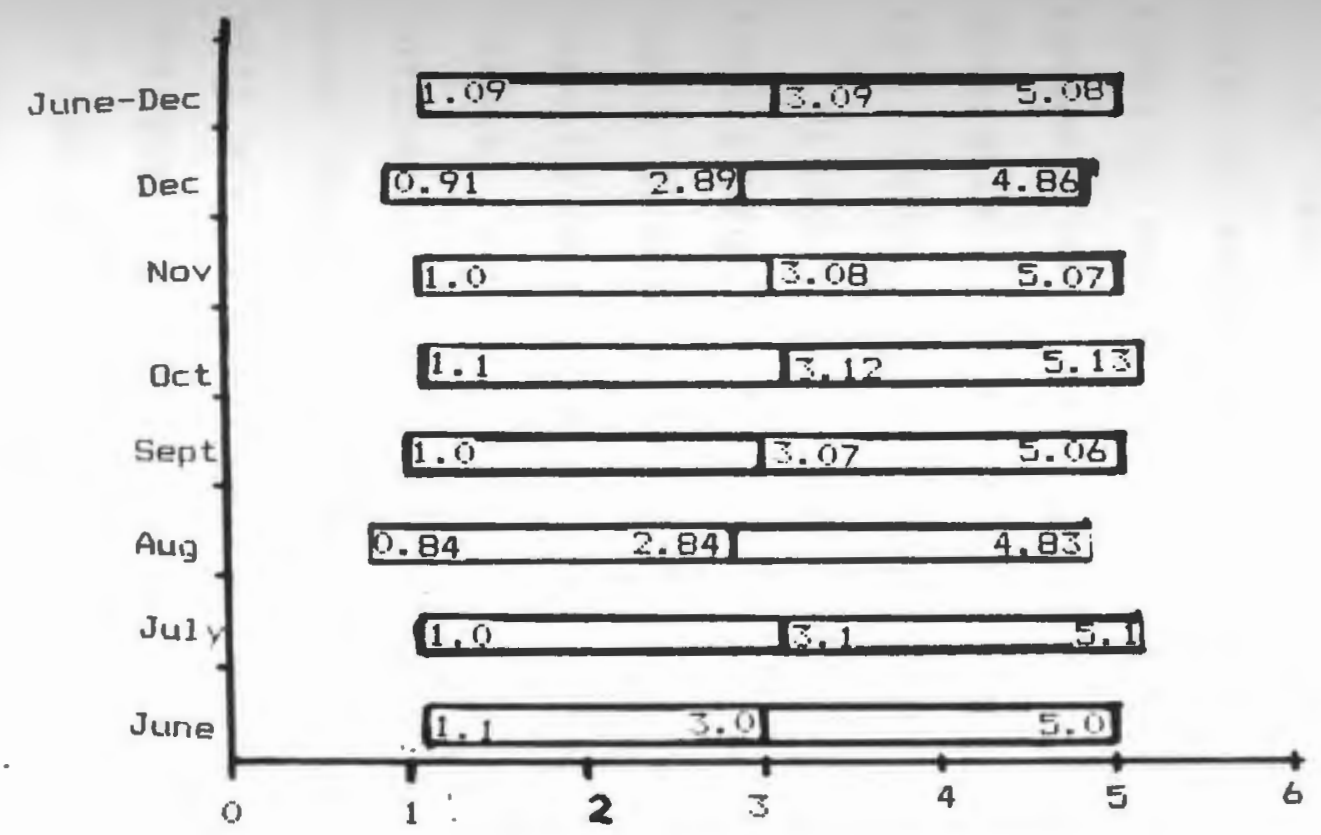

FIGURE 35

Ninety-five percent confidence intervals on slope (b) values from the monthly length-weight relationship for Siganus canaliculatus caught for the spear fishery. Juñe-Décember 1986 . 
change in species composition during the year, the estimated annual yield can be calculated by multiplying the catch by 1.7. The estimated annual yield based on this assuption is $4.17 \mathrm{mt} / \mathrm{sq} \mathrm{km} \mathrm{yr}$.

IV.

\section{Discussion}

A high species diversity is characteristic of the catch of small-scale fishermen who use a variety of fishing gears in coral reef areas. This is one of the reasons why the dynamics of such fisheries are difficult to analyse.

(4.1) Catch, Effort and Catch Per Unit Effort

Catches of spear, hook-and-line, and traps ranged from a high of $51 \mathrm{~kg}$ in June to a low of $23.5 \mathrm{~kg}$ per month in September (Fig 36). The wide variation in the results can be attributed to the different levels of fishing effort and to environmental factors which influenced the available biomass of fish in the study area. The monthly fluctuations in the catch per fishing gear are largely a function of fishing effort. These changes are strongly associated with weather conditions in the area. The differences in catches in the trap fishery between locations can be explained by the uneven fishing effort in both areas. During months in which the weather was calm, more traps were set in the outer edge of the lagoon where the coral cover is more abundant and more fish are expected to concentrate. 
FIGURE 36.

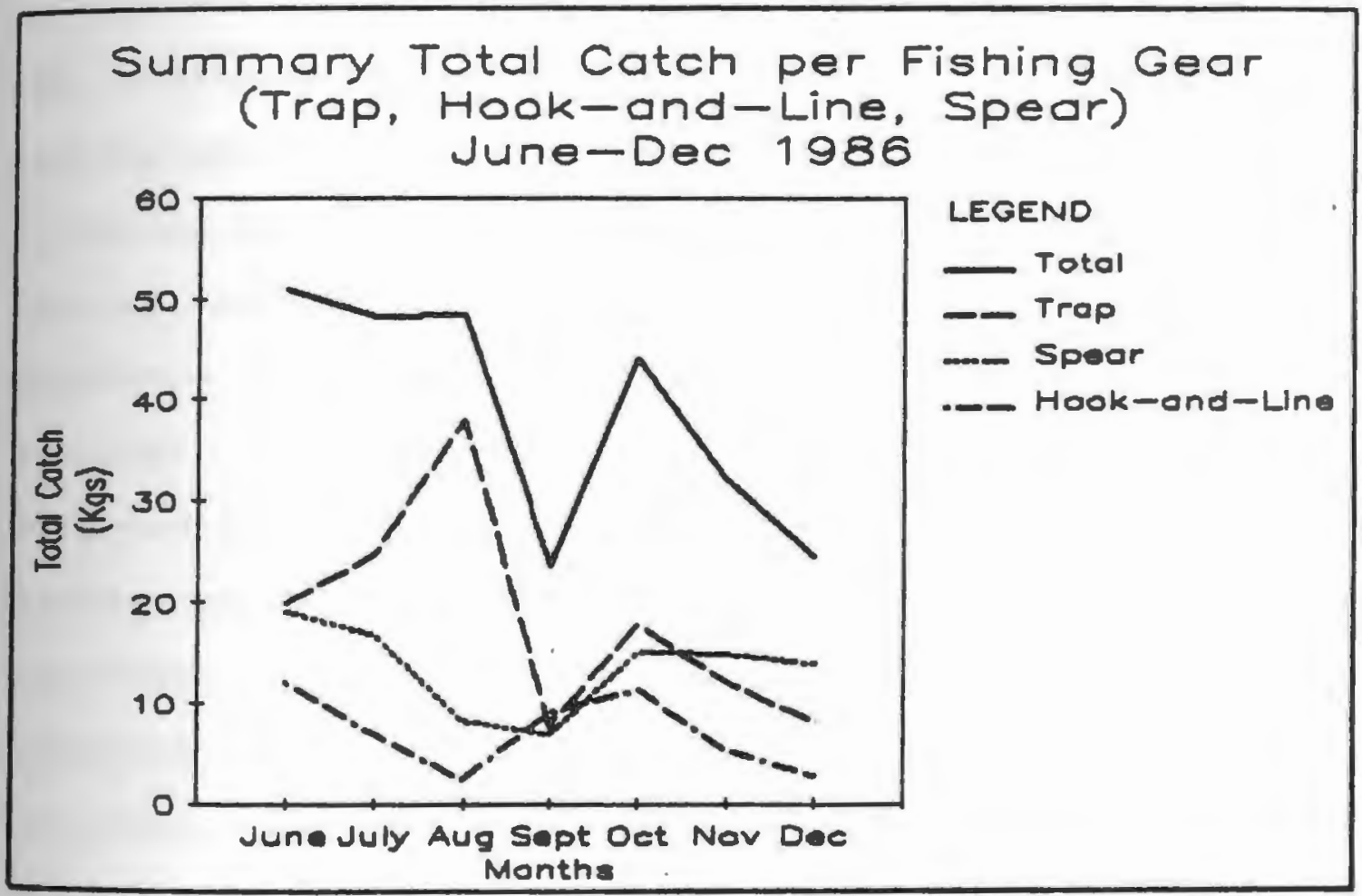


This does not mean that the fishing effort inside the lagoon decreased. On the contrary, the fishing effort in both areas was high, because some fishermen set traps in both areas. The collection of fishing effort data away from the fishing grounds was made more difficult by these changes in fishing areas.

Catches by spear were generally uniform throughout the sampling period. A drop was observed between August and september but an equilibrium was reached during the following months of the study. The catch of the spear fishery seemed to be mostly influenced by the monthly abundance of Siganus canaliculatus, the main target species. The highest fishing effort for the hook-and-line fishery was observed in June during the lanten period (good weather) before the arrival of the southwest monsoon. The hook-and-line fishery was affected the most by the weather pattern. During the southwest monsoon, rough seas hit the reef stopping fishermen from going fishing beyond the reef.

The catch per unit effort (CPUE) of the three fishing gears was generally low. There was considerable variation in CPUE for the hook-and-line fishery. The average CPUE was $0.58 \mathrm{~kg} / \mathrm{line-hour}$ (s.d.=0.187) which is very close to the values reported by Alcala and Gomez (1985) for Apo and Sumilon. Island in the Central Philippines. Expressing this in catch per hook/hr. was not possible because fishermen often 
use more than one hook. These estimates of CPUE are only for finfish; by-catch species such squid were not considered.

The CPUE for the trap fishery was uniform during the study period; averaging $0.129 \mathrm{~kg} / \mathrm{haul}(\mathrm{s.d.}=0.018$ ) for both areas. This value is low compared with the estimates of 0.7 to $0.13 \mathrm{~kg} / \mathrm{man}-\mathrm{h}$ for the trap fishery in Apo and Sulimon Island (Alcala and Gomez, 1985). These researchers also reported that the trap fishery in Apo Island was affected by the seasonal monsoon; resulting in higher catches during the southwest monsoon. This can be explained by the shift of fishing grounds to more protected areas. Fishermen around Silaki island tend to agree that there is no change in the abundance and species composition in the trap catches throughout the year.

Wright and Richards (1985) reported an average catch rate of $3.6 \mathrm{~kg} / \mathrm{man}$.hour for spear fishing at night and $1.2 \mathrm{~kg} / \mathrm{man}$.hour during the day in Papua New Guinea. In constrast, the average CPUE for the spear fishing at night in Cape Bolinao was $1.3 \mathrm{~kg} / \mathrm{man}$.hour $\left(s . d_{0}=0.35\right)$. These researchers concluded that the high catch rates at night were due to the target species. From these results it can be said that the catch per unit effort will be greatly influenced by the size of the target species sought. CPUE for the spear fishery in Cape Bolinao would be more influenced by the 
abundance of Siganus canaliculatus than by i'ts size. The monthly CPUE for the spear and hook-and- line are compared in Figure 37.

\section{(4.2) Catch Composition}

In coral reefs, most fishes are dependent on the substrate for shelter as well as food. It may be expected, therefore, that the nature of the substrate will influence the species composition and diversity of fishes in the area. Talbot (1965) indicated that there was a "clear relationship between quantity and complexity of fish population species structures with percentage and type of cover of the bottom. The catch composition of the trap fishery in Cape Bolinao does not seem to support these statements. 127 species were recorded for the trap fishery during the study (Apendices 4 and 5). Of these, 101 species were observed in the lagoon proper and 90 species were collected on the outer edge of the lagoon. 39 species were observed only in the lagoon. More or less distinct species assemblages were associated with each habitat type. However, some species overlapped. 58 species of the total 127 taken were found in both habitats studied and can be considered "reef cosmopolitan" species. This is in contrast to Goldman and Talbot (1976), who noticed a lack of species overlapping (18 26 species) between different habitats in one tree Island reef system, Australia. 
FIGURE 37.

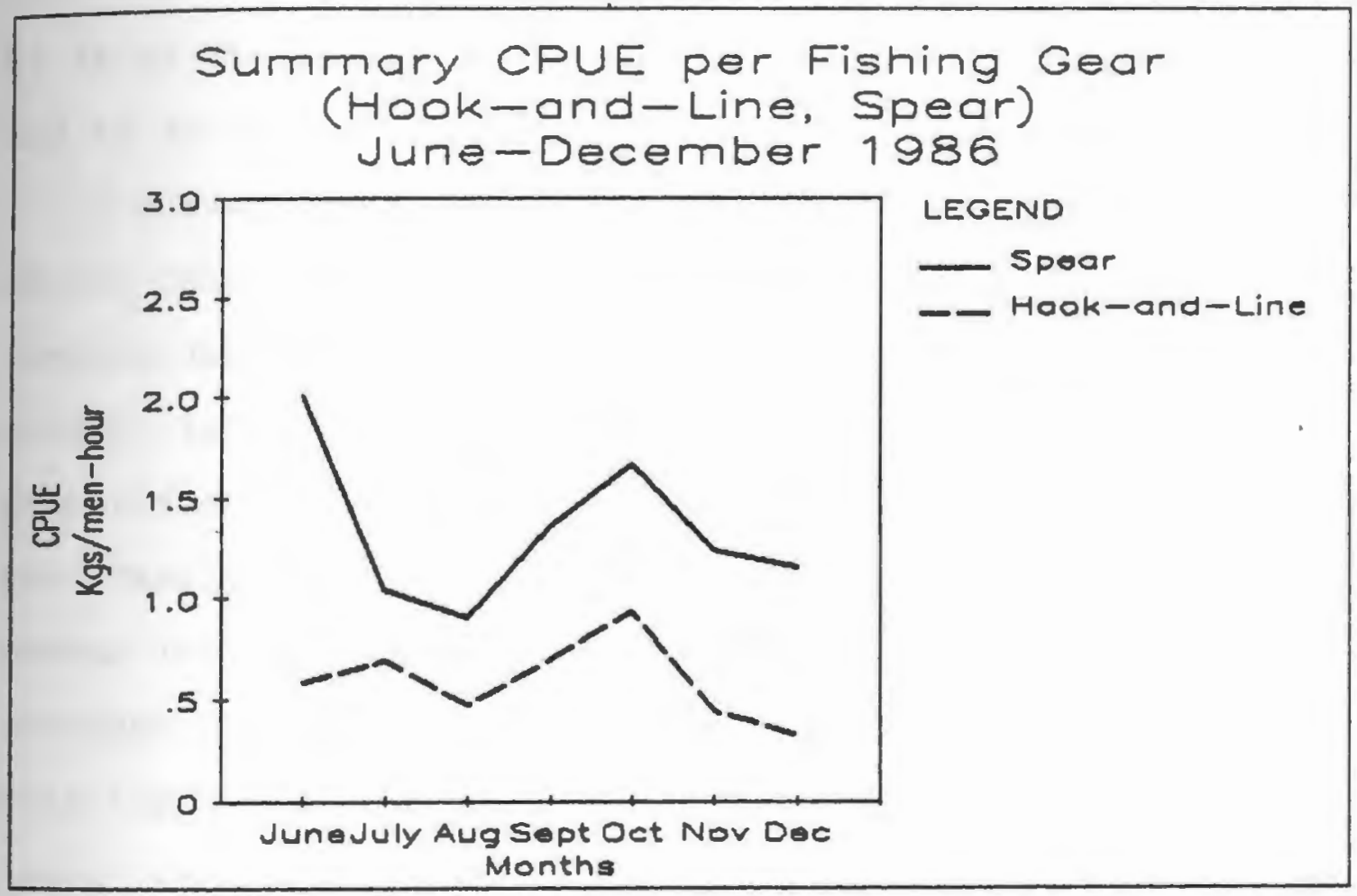


The outer edge (outside) habitat is more abundant than the lagoon (inside) habitat, but is less rich in species composition. From tables 6 and 7 it can be seen that the family Siganidae and Labridae accounted for $62.3 \%$ of the weight and $64 \%$ by number on the outer edge and 43.38 and 468 inside the lagoon.

A survey conducted by the Marine science Institute of the Philippines (MSI) using visual census techniques between June and November 1985 on the outer edge of Silaki Island showed a completely different species composition. The researcher from the MSI reported that the Family Pomacentridae was the most abundant by number (65.48) and the Family Acanthuridae was the most abundant by weight (38.5\%). The Family Siganidae was only important in terms of weight (25.5\%). However, there were some similarities in the results. The Families Mulliedae and Serranidae accounted for similar abundance by number in both surveys.

The variation in the species composition between the two surveys may have several causes, one of which is the selective nature of the trap to the type of fishes collected. Differences in species composition are influenced by the diverse and complicated behavior of coral reef fishes. For example, reef fishes are present in different species compositions during the day and night. Goldman and Talbot (1976) reported that a typical day mode of a coral reef is represented by 
the families Scaridae, Acanthuridae, Chaetodontidae, Labridae, Pomacentridae and large predators cruising along the reef edge. The nocturnal mode is quite different with members of Apogonidae, Holocentridae, Lutjanidae, Lethrinidae, and other families replacing the day families. Vivian (1973) found similar changes in species composition on an inner reef flat in Tulear (Madagascar). These changes in species composition due to nycthemeral rhythm suggested that the traps are sampling diurnal and nocturnal species distributions. On the other hand, visual censuses are missing the more secretive fishes such as Apogonids which are generally seen by divers during the daylight hours. Even the diurnal fishes can be overlooked when the reef has many crevices and caves.

Murdy (1979) reported 48 species representing 24 families in an artificial reef inside the lagoon in Cape Bolinao. He concluded that the artificial reef did not accumulate a large number of species because of the proximity to natural reef areas and the shallow depth of the lagoon. 13 of the 24 families were represented in trap catches inside the lagoon.

The results of a cluster analysis to see the degree of similarity between the two locations of traps (inside, outside) showed that no discrete clusters occur. The lagoon traps displayed significant similarities only with one another in terms of species 
composition. There were some clusters of similarities between both areas but only at lower levels of association. This may be related to species overlapping between the two areas.

The cluster analysis to see whether species associations ocurred between the two areas, showed that a high degree of similarity was exhibited between the species. A high degree of species association was displayed between members of the family Labridae and between menbers of the family Balistidae. Siganus spinus and Siganus canaliculatus exhibited the least degree of association. The high association between the members of the families Labridae and Balistidae can be expected from the schooling behavior characteristic of these families.

Demersal, reef attached species were the dominant component of the hook-and-line catch composition. Lethrinid and Lutjanid species were the most numerous with five species each. Lethrinids were the most abundant by number and weight. The species composition of the hook-and-line fishery is similar to that recorded in Papua New Guinea by Wright and Richards (1984). These records differ most noticeably in the change in species abundance; the Family Lutjanidae was the most abundant in number and weight. During this study the hook-and-line catches indicated that the distribution of these species was generally in waters 
deeper than $30 \mathrm{~m}$. Some lutjanid and lethrinid species were caught in the traps, which indicated that sea-grass beds or shallow waters are used as nursery grounds during their early life stages, while they are associated with the reef as adults.

Munro (1974) and Rivas (1970) agreed that juvenile species of lutjanids occur in shallow water and large adults in deeper waters but, they indicated that there was no rigid relationship between size and the depth at which individuals are captured. There is a seasonal bottom-gillnet fishery (Feb-April) in waters 30 to $50 \mathrm{~m}$ deep out of the reef of Cape Bolinao. Interviews with the fishermen and owners of the boats engaged in this operation suggested that hook-and-line and the bottom gillnets fisheries have similar species compositions. The abundance of large size fishes can be due to the large mesh size (4 inches) used for this fishery.

As was mentioned before, one species accounted for 828 of the spear fishery. There were other species but - they only accounted for $18 \%$ of the catch. Calvelo and Ginon (1974) found that Siganus sp. accounted for 20 to 508 of the catch of fish corrals in Cape Bolinao. The species composition of the spear fishery in Cape Bolinao differed completly with the catch composition recorded by Wass (1982) in America Samoa and by Wright and Richards (1984) in Papua New Guinea. These researchers reported a wide variarity of species; 
mainly reef and pelagic such as groupers snappers, jacks, mackerel, and others. The difference can be axplained by the presence of extensive seagrass beds and tidal flats in Cape Bolinao in which schools of Siganus canaliculatus tend to concentrate.

(4.3) Notes on the Biology

ith Compositions and Iength-weight relationships

Most of the available literature on coral reef biology only mentions Siganus spinus,siganus canaliculatus Lutjanus fulviflamma, Mulloidichthys falvolineatus, Siganus guttatus and Iutjanus gibbus. Thus discussion will be focus mainly on the above mentioned species.

Siganus spinus

There was clear evidence of different mean sizes between $\underline{S}$. spinus from inside and outside the reef. The smallest size observed was $7.5 \mathrm{~cm}$ and the largest was $18.5 \mathrm{~cm}$ (TL). The frequency distribution is skewed to the left, with a mode at $9.5 \mathrm{~cm}$ (TL). Schroeder (1980) reported a maximun length of $25 \mathrm{~cm}$ (SL) for $\mathrm{s}$. spinus. The length-weight relationships between the two locations show a slightly significant difference in the coefficient of allometry (b). The results for the combined area show allometric growth $b>3 \quad(r=.92)$.

Siganus canaliculatus

The smallest size of $\underline{S}$. canaliculatus was $9.5 \mathrm{~cm}$ and the largest $19.5 \mathrm{~cm}$ (TL). The mean sizes by location 
were significantly different. The length frequency distribution outside the lagoon showed a bimodal size distributions with peaks at $10.5 \mathrm{~cm}$ and $15.5 \mathrm{~cm}$ (TL). Rau and Rau (1980) reported common lengths of 10 to $15 \mathrm{~cm}$; with a maximum of $20 \mathrm{~cm}$. This study supports these results. The distribution inside the lagoon showed only one mode at $10.5 \mathrm{~cm}$. Similar results were observed by Hassen et al.(1977) in Palau. They observed bimodal distributions of female fish which imply two age groups. Males were characterized by a unimodal distribution. Fish $<18 \mathrm{~cm}$ (SL) were considered to belong to age $I$, while those $>18 \mathrm{~cm}$ (SL) were considered to be age II.

The length-weight relationships for the combined sample show allometric growth $b>3(r=.97)$. This value was different from the value obtained by Hasse et al.(1977) and Tsuda et al. (1974). The differences are probably due to differences in growth rates between the sample areas and to the fact that the fish used in this study were from $9.5-19.5 \mathrm{~cm}$ (TL) while Hassen et al. (1977) used fish from $11-24 \mathrm{~cm}$ (SL) and Tsuda et al used fish from $2 \cdot 5-20 \mathrm{~cm}$ (SL).

Siganus canaliculatus from the spear fishing fishery ranged from 8 to $22.2 \mathrm{~cm}$ (TL). There were no clear pattern of bimodal distribution between the monthly samples. The selection of the gear could account for the lack of bimodal distribution as spears 
catch larger fish than traps. The length-weight relationships of the combined data from June to December showed a isometric growth for $s$. canaliculatus $b=3 \quad(r=.97)$. August and November showed allometric growth $b<3$. These variations in the (b) value may be due to the fullness of stomach, stage of maturity, season or characteristic of the fish. The results of the regression coefficient (b) are slightly different from the one observed for the trap fishery. Mulloidichthys falvolineatus

The smallest M. falvolineatus caught in the spear fishery was $12.1 \mathrm{~cm}$ (TL) and the largest was $20 \mathrm{~cm}$. Rau and Rau (1980) reported that fish in the size range of $20-30 \mathrm{~cm}$ were common and a maximum size was $40 \mathrm{~cm}$. The length-weight relationships for this species showed a allometric growth $b<3 \quad(r=.96)$. These estimates of length distribution and the regression coefficient agree with the estimate reported by De la Cruz (1986) for this species in a fish corral in Guiuan Eastern Samar Philippines.

Siganus guttatus

The minimum size of $\mathrm{s}$. guttatus caught by the spear fihery was $11.4 \mathrm{~cm}$ and the largest was $21.5 \mathrm{~cm}$ (TL). Rau and Rau (1980) reported a common size of $\underline{\text { S. }}$ guttatus of $15-35 \mathrm{~cm}$ with a maximum of $40 \mathrm{~cm}$. The lengthweight relationship showed allometric growth $b>3$ $(r=.99)$. These estimates of length distribution and the 
regression coefficient agree with the estimate reported by De la Cruz (1986) for this species in a fish corral in Guiuan Eastern Samar Philippines.

Lutjanus fulviflamma

The minimum size of Lutjanus fulviflamma caught by the hook-and-line fishery was $19.8 \mathrm{~cm}$ and the largest was $30.5 \mathrm{~cm}$ (TL). Rau and Rau (1980), reported a common size range between $25-30 \mathrm{~cm}$ and a maximum of $35 \mathrm{~cm}$. The results of the study tend to agree with this observation. The length frequency distribution has a bimodal pattern. The length-weight relationship showed an isometric growth $b=3 \quad(r=.97)$. This is in agreement with De la Cruz (1986).

Lutjanus gibbus

The length frequency distribution for $\underline{L}$. gibbus could not be established because of the small sample size. The minimum size for this species was $16.5 \mathrm{~cm}$ and the largest was 39.5 (TL). The length-weight relationship showed an allometric growth $b<3 \quad(r=.99)$. Wright and Richards (1984) found a similar coefficient of allometric growth for this species in Papua New Guinea.

Scarus rhodopterus, Labrid A, Stagastes sp., Cheilinus trilobatus, Epinephalus merra,Apogon sp.' Gnatholepis puntang, Lethrinus rhodopterus and Lethrinus ornatus showed an allometric growth pattern (b > $3, b<3$ ). Lethrinus variegatus showed a isometric 
growth $(b=3)$.

The small sizes observed in the trap fishery indicated that growth overfishing has occurred. Johannes (1980) reported that this has taken place in many reef and lagoon areas throughout all the tropics.

\section{(4.4) Fish Yield}

The estimated finfish yield of Cape Bolinao smallscale fishermen who operated in waters less than 15-m deep is $4.17 \mathrm{mt} / \mathrm{sq} \mathrm{km} \mathrm{yr}$. This figure is low compared with the fish yield of small-scale fisheries of the tropical West Pacific. However, comparison between this estimate and others is difficult. Comparison is only possible if the area from which fish is harvested or counted is standarized (Wright and Richards, 1984). Wass (1982) calculated a fish yield of $27 \mathrm{mt} / \mathrm{sq} \mathrm{km}$ in a localized reef subjected to intensive fishing pressure in American Samoa. Similar conditions exist in Cape Bolinao. Wass' estimates included mackerel and jacks which accounted for 38.48 of the fish species and invertebrates. These are not included in this study. Alcala and Gomez (1985) reported fish yields ranging from 5 to $36 \mathrm{mt} / \mathrm{sq} \mathrm{km}$ yr in the Central Philippines. Some of these estimates are very high in comparison with the estimate of this study. This is due in part to the fact that only coral reef bottoms were included in their estimates. The fish yield from this study is greater than the fish yield reported by Munro (1977) in 
the Caribbean (maximum of $1.9 \mathrm{mt} / \mathrm{sq} \mathrm{km}$ ) and Jamaica $(1.2$ to about $4.3 \mathrm{mt} / \mathrm{sq} \mathrm{km})$. These results are also difficult to compare due to the different nature of both fisheries. Munro's results are largely from trap and handine fisheries.

MSI (1985) estimated the biomass for the outer reef to be between $18.5 \mathrm{mt} / \mathrm{sq} \mathrm{km}$ to $9.5 \mathrm{mt} / \mathrm{sq} \mathrm{km}$ in an area of 2.5 hectares. These results are quite high when compared with the fish yield obtained in this study. These results are also difficult to compare due to the different substrates considered in both studies and to the difference in species composition reported for both studies. Marshall (1985) believed that yields of at least $2 \mathrm{mt}$ should be expected. Yields as low as $1 \mathrm{mt}$ may reflect overfishing, underfishing, or stressed reef conditions.

Reef damage by dynamiting and poisoning together with the heavy fishing pressure are probably responsible for the low yields in the study area. Dynamiting is a widespread practice in Cape Bolinao. It is normal to hear more than 20 blasts in one day. The researcher counted 10 blasts in a period of 1 hour from 0530 to 0630 in the outer reef area.

The fish yield estimate in Cape Bolinao could be revised upward considerably if daily gleaning for invertebrates and the collection of aquarium fishes were taken into consideration. Trying to generalize and 
compare fish yields from different areas is difficult and may not be justified, because of the different Nerceptions about the description of the reef areas and the reef species on the part of the researchers.

v. Conclusions and Recommendations

1)Fishing in 'reef-lagoon' areas in Cape Bolinao remains an artisanal activity, by individuals, families or small groups. The fishing investment is relatively low and allows several islanders to partly satisfy their needs and to supply high quality protein to their diet. The introduction of new sources of jobs or new opportunities may help to decrease the complete dependence on marine resources in the area.

2) Increasing effort coupled with a decrease in available fishing area due to reef destruction and pollution can result in the decline of the catch and a reduction in per-capita effort: The practise of dynamite fishing is widespread in Cape Bolinao. The use of dynamite is considered to be totally unacceptable. Enforcement appears to be the major problem. Public education may provide a partial answer to this problem.

3) Besides differences in the species composition, a variety of ecological factors contribute to the peterogeneity of the fish communities. The existence of the temporary community, migration with the tide and nyctemeral changes in species composition are clear indications that the fish community of the lagoon 
cannot be dissociated from that of the nearby areas.

4) The presence of large-sized species from the hook-and-line fishery should be expected because of the fishing grounds where this operation takes place. The mean size length observed in this fishery reflects the wealth of the stock. A survey of the catches from the hook-and-line and the bottom gillnet fishery together with exploratory fishing in deeper waters is recommended. However, any increase or introduction of new technology should be carefully monitored, as populations, especially of larger carnivores in limited areas may be vulnerable to overfishing (Parrish, 1980).

5) Gear selectivity varies greatly between methods with regard to species and size of the fish caught. A knowledge of gear selectivity is essential if selectivity is expected to be used as a management tool. For example, it would be good to know if increasing the mesh size for the trap fishery would increase the size of the fish caught.

6) Good baseline data on the system is needed before management decisisons can be made. The collection of catch data and effort data to obtain biological information, and monitor changes in the system is considered necessary before any decisions are made. For example, In the spear fishery for siganus canaliculatus in Cape Bolinao, monitoring catch and effort would help to predict the amount of harvestable fish and the 
seasonal abundance of the species. Knowing the timing, location and size of the fish would allow the manager to estimate the number of juveniles available in the area and to control the fishing directed at spawing aggregations.

7) The lack of standarization of the area used in fish yield estimates needs to be solved. The stratification of the area to be studied may be an answer to this problem. An obvious division would be between reef, coastal lagoon, seagrass beds and further sub-divisions based on the type of botton substrate.

8) Reports of high fish yields for heavily exploited reefs, such as Cape Bolinao should be carefully reviewed and monitored. In many cases, It would be preferable to report more conservative estimates. It is better to report underestimates than overestimates, in order to make more rational decisions.

9) A management recomendation for Cape Bolinao must consider fishermen activities so that the future generations will still be able to enjoy these coral reef resources. 
Alcala, A.C. 1981. Fish yield of coral reefs of Sumilon Island, Central Philippines. Nat Res. Counc. Philipp. Res. Bull. 36:1-7.

Alcala, A.C. and E.D. Gomez. 1985. Fish Yields of Coral reefs in Central Philippines. Proc. Fifth Int. congress. 5: 521-524. Tahiti.

Alcala, A.C. and T. Luchavez. 1982. Fish yeild of the coral reef surronding Apo Island, Negros Occidental Central Visayas, Philippines. Proc. Fourth Int. Coral Reef Symp. 1:69-73.

Anderson, R.O. and S.J. Gutrewter. 1983. Length, weight, and Associated Structural Indices. Fisheries Techniques. pp.283-300. L.Nielsen and D. Johnson (eds) American Fisheries Sociaty.

Austin, H.M. 1971. A survey of the ichthyofauna of the mangroves of western Puerto Rico during December, 1967August, 1968. Caribb. J. Sci. 11: 27-39.

Boardman, C. and D. Weiler. 1980. Aspects of the life history of three deepwater snappers around Puerto Rico. Proc. Gulf Caribb. Fish. Inst. 32:158-172.

Bolanos, A.B. and P.M. AliNo. 1984. Some Aspects of Degradation in The Coral Reef Ecosystems of The Philippines. Proc. MAB/ COMAR Regional Seminar, Tokyo, 1984 .

Calvelo, R.R. and J.S. Ginon. 1974. Siganid fishery of Northwestern Pangasinan. Phil. Jou. Fish. 12 (1 and 2) : 114-130.

Carpenter, K.E. 1977. Philippine coral reef fisheries resources. Philipp. J. Fish. 17:95-125.

Carpenter, K.E. and A.C. Alcala. 1977. Philippine Coral Reef Fisheries Resources. Part II. Muro-ami and Kayakas Reef Fisheries, Benefit or Bane? The Philippine J. of Fish. 15:217-235.

Corpuz, V.T., P.CastaNeda. and J. C. Sy. 1983. Traditional muro-ami, an effective but destructive coral reef fishing gear ICLARM Newsletter 8 (1): 12-13.

Craig, A.K. 1976. Trapping experiments with snappers in south Florida. pp. 222-236 In H.R. Bullis, Jr. and A.C. Jones, (eds.) Proceedings: Colloquium on snappergrouper fishery resources of the western central Atlantic Ocean. Fla. Sea Grant Program Rept. \# 17. 
Craik, G.J.S. 1982. Recreational fishing on the Great Barrier. Reef Proc. Int. Coral Reef. Symp. 1:45-52.

De La Cruz, M.T. 1986. Catch composition and seasonal abundance of fish corral caught fishes in Guiuan, Eastern Samar with notes on the Biology of some commercial important species. M.Sc. Univ. of Philippines. Visayas.

Forman, S. 1970. The raft Fishermen. Bloomington: Indiana University Press.

Fortes, M.D. 1984. Ecological Assessment and cultivation of Seagrasses at Bolinao Bay for Biomass Production. NRCP Research Bulletin, vol 39, \#1.

Fraser, J.M. 1955. The smallmouth bass fishery of South Bay, Lake Huron. J. Fish. Res. Board Can. 12: 147-177.

Fry, F.E.J. 1949. Statistics of a laketrout fishery. Biometrics 5:27-67.

Hartsuijker, L. and W.E. Nicholson. 1981. Results of a potfishing survey on Pedro Bank (Jamaica): The relations between catch rates, catch composition, the size of fish and their recruitment to the fishery. Fisheries Division, Ministry of Agriculture, Jamaica. Technical Report \# 2 of the project. FAO/TCO/JAM 8902: Potfishing survey of Pedro Bank, 44p.

Hasse, J.J., Madraisau, B. and J.P. McVey. 1977. Some aspects of the life hystory of Siganus canaliculatus (Park) (Pisces: Siganidae) in Palau. Micronesica 13(2): 297-312.

High, W.L. and A.J. Beardsley. 1970. Fish behavior from an undersea Habitat. Comm. Fish. Rev. 32(10): 31-37.

High, W.L. and I.E. Ellis. 1973. Underwater observations of fish behavior in traps. Helgol. Wiss. Meeresunters, 24: 341-347.

Hudson, J.H. Shinn, E.A. and Robbin, D.M. 1982. Effects of offshore oil on Philippine Fishery industry. Manila; Media Systems, Inc.

Goldman, B. and F.H. Talbot. 1976. Aspects of the ecology of coral reef fishes, p.125-154. In O.A. Jones and Endean (eds.) Biology and geology of coral reefs, Vol. III. Bilogy 2. Academic Press, New York.

Gomez, E.D., A.C. Alcala. and A.C. San Diego 1981. Status of Philippine coral reefs. Proc.Fourth Int. Coral Reef 
Symp. $1: 275-282$.

Gulland, J.A. 1979. Report of the FAO/IOP Workshop on the fishery resources of the western Indian Ocean south of the Equator. Mahe; Seycnelles; Oct-Nov 1978. IDFDEV79/45.:

Johannes, R.E. 1980. Using knowledge of reproductive behavior of reef and lagoon fishes to improve fishing yields. In: Bardach, J., Magnusson, J.J., May, R., Reinhart, J.(eds) Fish behavior and its use in capture and culture of fishes. ICLARM, Manila pp.247-270

Jones, R.S. and J.A. Chase. 1975. Community Structure and Distribution of Fishes in an Enclosed High Island Lagoon in Guam. Micronesica $11(1): 127-148$.

Kawaguchi, K. 1977. Handline and longline fishing explorations for snapper and related species in the Caribbean and adjacent waters. Mar. Fish. Rev. 36(9): 8-20.

Kirwood, G.P. 1982. Simple models for multispecies fisheries. pp. 83-98. In D. Pauly and G. Murphy (eds) . Theory and management of tropical fisheries. ICLARM Conference Procedings 9, 360 pp.

Koslow, J.A., Hanley, F. and R. Wicklund. 1986. The impact of Fishing on the Reef Fish of Pedro Bank and Port Royal, Jamaica: A comparison of trap surveys, 1969-73 and 1986. In press: Proc. Gulf Caribb. Fish. Inst. 38 (1986).

Larkin, P.A. and N. Gazey. 1982. Applications of ecological simulation modelsto management of tropical multispecies fisheries. pp. 123-140 In D. Pauly and G. Murphy (eds). Theory end management of tropical fisheries. ICLARM Conference Procedings 9, $360 \mathrm{pp}$.

Librero, A.R., D. Ramos. and L. Lapie. 1982. Fish capture technology: Its relationship to productivity income and employment in the Philippines. Fish. Res. J. 7(2): $1-20$.

Luckhurst, B. and J. Ward. 1986. Behavioural dynamics of coral reef fishes in Antillian fish traps at Bermuda. In press: Proc. Gulf Caribb. Fish. Inst. 38 (1986).

Marriot, S.P. 1984. A summary report on the South Tarawa artisanal fishery. Mimeo Rept.;Fisheries Division; Kiribati: 1-21.

Marshall, N. 1980. Fisheries yields of coral reefs and adjacent shallow water enviroments. pp. 103-109 in 
Saila and Roedel (eds). 1980.

Marshall, N. 1985. Ecological sustainable yield (Fisheries Potential) of coral reef enviroments. Proc. Fifth Int. Coral Reef Congress 5:Tahiti.

Marten, G.G. 1981. Ecological Data requirements for managing Hawail's coastal zone fishery. Coatal Zone Fishery Management Program, Division of Fish and Game, Honolulu, Hawaii.

Marten, G.G. 1979a. The impact of fishing on the inshore fishery of Lake Victoria (east Africa). J. Fish. Res. Board Can. 36: 891-900.

Marten, G.G. 1979b. Predator removal: its impact on fish yields in Lake Victoria (East Africa). Science 203: 646-647.

Marten, G.G. and J.J. Polovina. 1982. A comparative study of fish yields from various tropical ecosystems. pp. 255-289 In D. Pauly and G. Murphy (eds). Theory and management of tropical fisheries. ICLARM Conference Procedings 9, $360 \mathrm{pp}$.

Miller, R.J. 1986. Traps as a Survey Tool for Animal Density. In press: Proc. Gulf Caribb. Fish. Inst. 38 $(1986)$.

MSI Annual Report 1986. Trophic Dynamics and Fisheries Yields in a coral reef. Coral Reef Research Team, Marine Science Institute. University of the Philippines.

Munro, J.L. 1974. The Biology, ecology, exploitation and management of Caribbean reef fishes. VI. Summary of the potential productivity of Jamaica fisheries. Zool. Dep. Univ. West Indies 5(3): 1-82.

Munro, J.L. 1976. Aspects of the Biology and Ecology of Caribbean reef fishes: Mullidae (goat fishes). J. Fish Biol. 9: 79-97.

Munro, J.L. 1977. Actual and potential fish production from the coralline shelves of the Caribbean sea. Proc. CICAR-II Symp. Caracas, 1976. FAO Fisheries Report \# $200,301-321$.

Munro, J.L. 1980. Stock assessment models: Applicability and utility in Tropical small-scale fisheries. pp. 35-47 in Saila and Roedel (eds). 1980.

Munro. J.L. 1983. Carribean Coral reef fisheries resources. Munro, J.L., editor. ICLARM Studies and 
Reviews 7, 276 pp., Manila.

Munro, J.L., P.H. Reeson. and V.C. Gaut. 1971. Dynamic factors affecting the performance of the Antillean fish Trap. Proc. Gulf Caribb.Fish. Inst. 23: 184-194.

Munro, J.I. V.C.Gaut, R.Thompson and P.H. Reeson. 1973. The spawing seasons of Caribbean reef fishes. J. Fish Biol. 5: 69-89.

Munro, J.L. and Williams, D.MCB. 1985. Assessment and Management of Coral Reef Fisheries: Biological, Enviromental and Socio- economic aspects. Proc. Fifth Int. Coral Reef Congress, 4: Tahiti.

Murdy, E.O. 1979. Fishery Ecology of the Bolinao Artificial reef. Kalikasan, Philipp. J. Biol. 8 (2): 121-154.

Odum, W.E.,J.C.Zieman. and E.J. Heald. 1973. The importance of vascular plant detritus to estuaries. Proc. Coastal Marsh and Estuary Management Symp. pp. 91-114.

Olsen, D.A., A.E. Dammann, J.F. Hees, J.R. Sylvester, and J.A. Yntema. 1973. The ecology of fishes in two mangrove lagoons in the U.S. Virgin Islands. MS Rep. Puerto Rico International Underseas Laboratory. 42p.

Parrish, J.D. 1980. Effects of exploitation Patterns upon reef and Lagoon communities. In J.L. Munro (ed). Ecological aspects of coastal zone management. Proc. Seminar on Marine and Coastal Processes in the Pacific. Motupore Is. Res. Centre. July 1980. UNESCO- ROSTSEA; Jakarta. : 84-100.

Pollnac, R.B. 1976. Continuity and change in Marine Fishing Communities. Anthropology Working Paper \# 10. Department of Sociology and Anthropology. International Center for Marine Resources Development. Univ. Of Rhode Island.

Powles, H. and C.A. Barans. 1980. Groundfish monitoring in sponge-coral areas off the south eastern United States. Mar. Fish. Rev. 42(5): 21-35.

Ralston, S. 1982. Influence of hook size in the Hawaiian deep-sea handline fishery. Can. J. Fish. Aquat. Sci. 39: $1297-1302$.

Rivas, L.R. 1970. Snappers of the western Atlantic. Comm. Fish. Rev. 32(1): 41-44.

Rau, N. and A. Rau. 1980. Commercial fishes of the 
Philippines. German Agency for Technical Cooperation (GTZ), Escerborn, Germany. $623 \mathrm{pp}$.

Russ, G. 1985. Effects of Protective Management on Coral Reef Fishes in The Central Philippines. Proc. Fifth Int. Coral Reef Congres. 4:219-224. Tahiti.

Russe1l, B.C., F.H. Talbot, G.R.V. Anderson. and B.Goldman. 1978. Collection and sampling of reef fishes in coral reefs: Research Methods. Edited by D.R. Stoddart and R.E. Johannes, UNESCO,Norwich U.K. 329-345.

Saila, S.B. and P. M. Roedel. (eds). 1980. Stock assesssment for tropical small-scale fisheries. Int. Center for Marine Resources Dev., Univ. Rhode Island, Kingston.

Saila, S.B. C.W. RecksieK., M.H. Prager. 1986. Fisheries Science Applications System. University of Rhode Island and old Dominion University [in press].

Sainsbury, K.J. 1982. The ecological basis of tropical fisheries management. pp. 167-194 in D. Pauly and G. Murphy (eds). Theory and management of tropical fisheries. ICLARM Conference Procedings 9, $360 \mathrm{pp}$.

Sale, P.F. 1982. The structure and dynamics of coral reef fish communities. pp. 241-253 in D. Pauly and G. Murphy (eds). Theory and management of tropical fisheries. ICLARM Conference Procedings 9, 360 pp.

Schroeder, R.E. 1980. Philippines Shore Fishes of the Western Sulu Sea. Bureau of Fisheries and Aquatic Resources and NMPC Books, Manila.

Smith, C.L. and J.C. Tyler. 1973. Direct observations of resource sharing in coral reef fish. Helgolander wiss. Meeresunters. 24: 264-275.

Smith, S.V. 1978. Coral reef area and constructions of reefs and processes and resources of the world oceans. Nature 273: 264-275.

Stevenson, D.K. and N. Marshall. 1974. Generalization on the Fisheries Potential of Coral Reef and adjacent shallow-water enviroments. Proc. 2nd. Internat. Coral Reef. Symp. 1: 147-156.

Stevenson, D.K. and P. Stuart-Sharkey. 1980. Performance of wire fish traps on the western coast of Puerto Rico. Proc. Gulf Caribb. Fish. Inst. 32: 173-193.

Sylvester, J.E. and A.E. Dammann. 1972. Pot fishing in the 
Virgin Islands. Mar. Fish. Rev. 34 (9-10): 33-35.

Talbot, F.H. 1965. A description of the coral structure of Tutia Reef (Tanganyika Territory, East Africa) and its fauna. Proc. Zool. Soc. London 145: 431-470.

Taylor, R.G. and R.H. McMichael, Jr. 1983. The wire fish trap fisheries in Monroe and Collier Counties, Florida Marine Research Publications \# 39. 19pp.

Thompson, R. and J.L. Munro. 1974a. The biology, ecology and bionomics of the jacks, Carangidae. Reprinted pp. 59-81 in Munro (ed), 1983.

hompson, R. and J.L. Munro. 1974b. The biology and bionomics ofthe hinds and groupers, Serranidae. Reprinted pp.59-81. in Munro (ed), 1983.

Thompson, R. and J.L. Munro 1974c. The biology, ecology and bionomics of the snappers, lutjanidae. Reprinted pp. 94-109 in Munro (ed), 1983.

Tsuda, R.T. and P.G. Bryan. 1973. Food preferences of Juvenile Siganus rostratus and $\mathrm{S}$. spinus in Guam. Copeia 1973: 604 $-\overline{606}$.

Vivien, M. 1973. Ecology of the fishes of the inner coral reef flat in Tulear (Madagascar). J. Mar.Biol. Ass. India, $15(1): 20-45$.

Wass, R.C. 1982. The shoreline fishery of America Samoa past and present. In J.L. Munro (ed). Ecological aspects of coastal zone management. Proc. Seminar on Marine and Coastal Processes in the Pacific. Motupore Is. Res. Centre. July 1980. UNESCOROSTSEA; Jakarta.:51-83.

Willians, T. 1977. The Raw Material of Population Dynamics. In Fish Population Dynamics. Edited J.A.Gulland 1977. John Wiley \& Sons. Ltd.

Wright, A. and A.H. Richards. 1985. A multispecies fishery associated with coral reefs in Tigak Islands Papua New Guinea. Asian Marine Biology . 2 pp. 69-84.

Zieman, J.C. 1975. Seasonal variation of turtle grass, Thalassia testudinum Konig, with reference to temperature and salinity effects. Aquat.Bot. 1:107-124. 
Appendix 1

Sumary of trap catches in the outer edge, effort

and catch per unit effort by saepling day. Cape Bol inao.

Phil ippines.

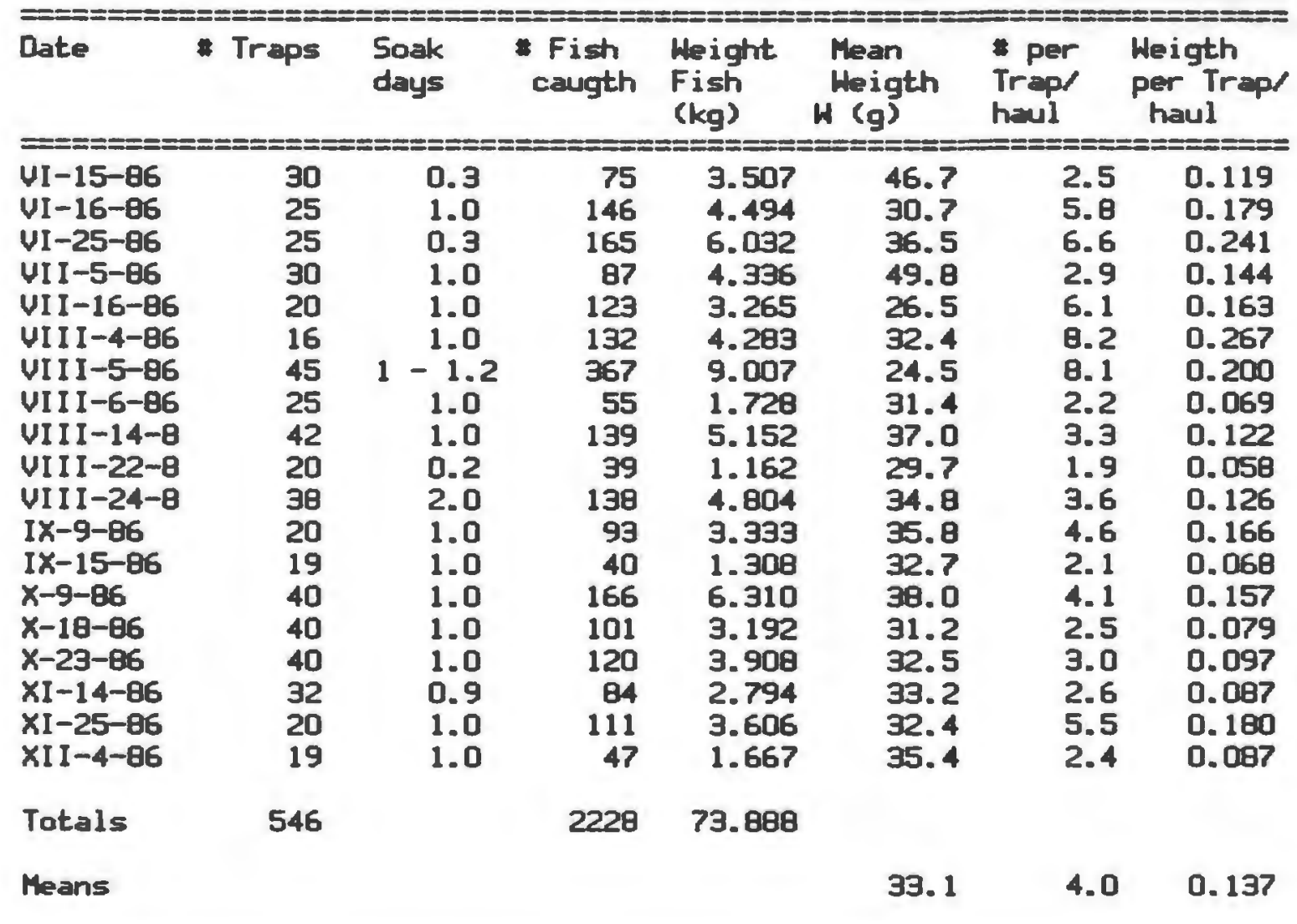


Pppendix 2

Sumary of trap catches inside the lagoon, effort and catch per unit effort by sampling day.

\begin{tabular}{|c|c|c|c|c|c|c|c|}
\hline Date & * Traps & $\begin{array}{l}\text { Soak } \\
\text { days }\end{array}$ & $\begin{array}{l}\text { Fish } \\
\text { caugth }\end{array}$ & $\begin{array}{l}\text { Weight } \\
\text { Fish } \\
\text { (kg) }\end{array}$ & $\begin{array}{l}\text { Mean } \\
\text { Weigth } \\
W(g)\end{array}$ & $\begin{array}{l}\text { per } \\
\text { Traph } \\
\text { haul }\end{array}$ & $\begin{array}{l}\text { Weigth } \\
\text { per Trap } \\
\text { haul }\end{array}$ \\
\hline
\end{tabular}

\begin{tabular}{|c|c|c|c|c|c|c|c|}
\hline $\begin{array}{l}\text { UI-15-86 } \\
\text { UI-16-86 } \\
\text { UI-25-86 } \\
\text { UII-1-86 } \\
\text { UII-3-86 } \\
\text { UII-16-86 } \\
\text { UII-22-86 } \\
\text { UII-23-86 } \\
\text { UIII-4-86 } \\
\text { UIII }-5-86 \\
\text { UIII-6-86 } \\
\text { UIII } 24-8 \\
\text { IX-9-86 } \\
\text { X-3-86 } \\
\text { X-8-86 } \\
\text { XI-9-86 } \\
\text { XII-9-86 } \\
\text { XII-15-86 }\end{array}$ & $\begin{array}{l}10 \\
19 \\
27 \\
12 \\
22 \\
46 \\
41 \\
17 \\
26 \\
24 \\
15 \\
23 \\
25 \\
40 \\
40 \\
31 \\
19 \\
19\end{array}$ & $\begin{array}{c}1 \\
1 \\
3 \\
1 \\
1 \\
1-2 \\
1 \\
1 \\
1 \\
1 \\
1 \\
1 \\
1 \\
1 \\
1 \\
1 \\
1 \\
1\end{array}$ & $\begin{array}{r}52 \\
63 \\
41 \\
49 \\
161 \\
342 \\
172 \\
51 \\
92 \\
150 \\
101 \\
107 \\
99 \\
109 \\
50 \\
171 \\
70 \\
173\end{array}$ & $\begin{array}{l}1.854 \\
2.398 \\
1.536 \\
1.256 \\
3.437 \\
7.560 \\
3.710 \\
1.043 \\
2.619 \\
3.133 \\
2.979 \\
2.995 \\
3.089 \\
2.973 \\
1.307 \\
5.610 \\
1.339 \\
5.077\end{array}$ & $\begin{array}{l}35.6 \\
37.9 \\
37.4 \\
25.6 \\
21.3 \\
22.1 \\
21.5 \\
20.4 \\
28.4 \\
20.8 \\
27.5 \\
27.4 \\
33.2 \\
27.5 \\
26.1 \\
32.8 \\
19.1 \\
29.3\end{array}$ & $\begin{array}{l}5.2 \\
3.3 \\
1.5 \\
4.0 \\
7.3 \\
7.4 \\
4.1 \\
3.0 \\
3.5 \\
6.2 \\
7.2 \\
4.7 \\
3.7 \\
2.7 \\
1.2 \\
5.5 \\
3.6 \\
9.1\end{array}$ & $\begin{array}{l}0.185 \\
0.125 \\
0.056 \\
0.104 \\
0.156 \\
0.164 \\
0.090 \\
0.061 \\
0.100 \\
0.130 \\
0.198 \\
0.130 \\
0.123 \\
0.074 \\
0.032 \\
0.180 \\
0.070 \\
0.267\end{array}$ \\
\hline $\begin{array}{l}\text { Totals } \\
\text { Means }\end{array}$ & 456 & & 2046 & 53.904 & 26.3 & 4.4 & 0.118 \\
\hline
\end{tabular}


Pppendix 3

Conterigancy table of the four ajor fanilies represented

in the catches of traps inside and outside a fringing reef

Cape Elol inao. Phi l ippii nes.

\begin{tabular}{|c|c|c|c|c|c|c|c|c|c|c|c|}
\hline \multirow{2}{*}{\multicolumn{2}{|c|}{ Trap A }} & \multicolumn{2}{|c|}{ Siganidae } & \multicolumn{2}{|c|}{ Labridae } & \multicolumn{2}{|c|}{ Scaridae } & \multicolumn{2}{|c|}{ Serranidae } & \multicolumn{2}{|c|}{ Totals } \\
\hline & & I & $\mathbf{0}$ & I & 0 & I & 0 & I & 0 & I & 0 \\
\hline June & $\begin{array}{l}T \\
\%\end{array}$ & $\begin{array}{l}34 \\
21.7\end{array}$ & $\begin{array}{r}221 \\
57.5\end{array}$ & 30.1 & $\begin{array}{r}71 \\
18.4\end{array}$ & $\begin{array}{r}57 \\
12.4\end{array}$ & $\begin{array}{r}71 \\
18.4\end{array}$ & $\begin{array}{r}24 \\
15.3\end{array}$ & 0.26 & $\begin{array}{r}119 \\
76.2\end{array}$ & $\begin{array}{r}364 \\
94.5\end{array}$ \\
\hline July & $\begin{array}{l}T \\
\%\end{array}$ & $\begin{array}{l}220 \\
28.7\end{array}$ & $\begin{array}{r}73 \\
34.4\end{array}$ & $\begin{array}{r}177 \\
23.1\end{array}$ & $\begin{array}{r}79 \\
37.2\end{array}$ & $\begin{array}{r}14 \\
1.83\end{array}$ & $\begin{array}{r}17 \\
8.01\end{array}$ & $\begin{array}{r}73 \\
9.5\end{array}$ & 2.35 & $\begin{array}{r}484 \\
63.2\end{array}$ & $\begin{array}{r}174 \\
81.9\end{array}$ \\
\hline Septenber & $\begin{array}{l}-T \\
\%\end{array}$ & $\begin{array}{l}26 \\
27.9\end{array}$ & $\begin{array}{r}35 \\
26.3\end{array}$ & $\begin{array}{r}35 \\
38.6\end{array}$ & $\begin{array}{r}29 \\
21.8\end{array}$ & $\begin{array}{r}24 \\
258\end{array}$ & $\begin{array}{r}29 \\
21.8\end{array}$ & - & $\begin{array}{r}9 \\
6.7\end{array}$ & $\begin{array}{r}85 \\
91.3\end{array}$ & $\begin{array}{r}102 \\
76.6\end{array}$ \\
\hline October & $\begin{array}{l}T \\
\%\end{array}$ & $\begin{array}{l}46 \\
30.6\end{array}$ & $\begin{array}{r}40 \\
10.3\end{array}$ & $\begin{array}{r}34 \\
22.6\end{array}$ & $\begin{array}{r}54 \\
13.9\end{array}$ & $\begin{array}{r}7 \\
4.6\end{array}$ & $\begin{array}{r}42 \\
10.8\end{array}$ & $\begin{array}{l}6 \\
4\end{array}$ & $\begin{array}{r}37 \\
9.5\end{array}$ & $\begin{array}{l}93 \\
62\end{array}$ & $\begin{array}{r}173 \\
44.5\end{array}$ \\
\hline December & $\begin{array}{l}\mathrm{T} \\
\%\end{array}$ & $\begin{array}{r}45 \\
18.5\end{array}$ & $\begin{array}{r}7 \\
14.8\end{array}$ & $\begin{array}{r}83 \\
34.1\end{array}$ & $\begin{array}{r}11 \\
23.4\end{array}$ & $\begin{array}{r}21 \\
8.6\end{array}$ & $\begin{array}{r}13 \\
27.6\end{array}$ & $\begin{array}{r}8 \\
3.29\end{array}$ & 8.5 & $\begin{array}{r}109 \\
63.7\end{array}$ & $\begin{array}{r}35 \\
74.3\end{array}$ \\
\hline
\end{tabular}


Appendix 4

Species composition for trap fishery in the outer edge of a coral reef lagoon. Cape Bolinao.

(1)

Fami 1 y/Species

$\mathbf{N}$

$\% N$

W $\% W$

Ave.

S. D.

(g) Length

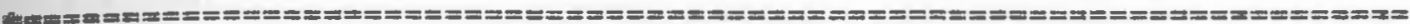

Acanthuridae

Acanthurus sp.

Acanthurus

triostegatus

Naso 1 iteratus

Naso sp.

Sub-total

$\begin{array}{rrrrrr}2 & 0.08 & 54 & 0.07 & 11.4 & 0.15 \\ 1 & 0.04 & 8 & 0.01 & 6.4 & \\ 3 & 0.13 & 104 & 0.14 & 9.1 & 0.9 \\ 6 & 0.26 & 95 & 0.12 & 10.0 & 2.22 \\ -12 & 0.53 & 261 & 0.35 & & \end{array}$

Apogonidae

Apogon bandenensis

Apogon sp.

Cheilodipterus $5 p$.

Sub-total

$\begin{array}{cc}2 & 0.08 \\ 40 & 1.79 \\ 1 & 0.04 \\ -43 & 1.92\end{array}$

\begin{tabular}{rr}
769 & 1.04 \\
49 & 0.06 \\
\hline 818 & -1.11
\end{tabular}

9.8

1. 14

15.0

Gal istidae

Bal i stapus angel atus

Balistapus 5p.

Bal istapus undul atus

Balistes $A$

Balistes argul atus

Balistes sp.

Canthehines pardalis

Stephanolysis

Tomemtosus

Sub-total

0.04

0.04

90

0.12

15.3

1

41

0.05

12.6

$9 \quad 0.4$

243

11

0.49

0.32

10.3

158

0.21

13.9

5.57

10.04

28

0.03

10. 3

$6 \quad 0.26$

139

0.18

9.5

0.53

2

0.08

54

0.07

11.0

0.15

10

0.44

95

0.12

8. 0

0.67

\section{Blenni i dae}

Sal arias

fasciatus

2

0.08

38

0.05

10.9

2.35

Chaetodontidae

Chaetodon auriga

C. citrinel lus

C. kleini

C. mel anotus

C. raffesei

c. trisfaci atus

c. vagabundus

Sub-total

$\begin{array}{rr}12 & 0.53 \\ 1 & 0.04 \\ 2 & 0.08 \\ 1 & 0.04 \\ 1 & 0.04 \\ 1 & 0.04 \\ 1 & 0.04 \\ -19 & -0.85\end{array}$

$\begin{array}{r}103 \\ 3 \\ 9 \\ 10 \\ 9 \\ 30 \\ 14 \\ \hline 178\end{array}$

0.13

.00

0.01

0.01

0.01

0.04

0.01

6.7

1. 39

6.0

5.8

0.45

6.2

6.0

9. 0

8. 3

0.24 
Haemul i dae

Plector lynchus

di agrammus
P. I ineatus

Sub-total

$\begin{array}{cc}3 & 0.13 \\ -1 & 0.04 \\ -4 & 0.17\end{array}$

$\begin{array}{r}84 \\ -4 \\ \hline 88\end{array}$

0.11

11.4

0.14

\begin{tabular}{rr}
4 & 0.18 \\
2 & 0.08 \\
1 & 0.04 \\
\hline
\end{tabular}

$-109$

0.01

7.5

0.12

Holocentridae

Adi oryx ruber

Adioryx sp.

Flammeo sammara

0.32

69

\begin{tabular}{ll}
0.09 & 12.1 \\
0.05 & 13.4 \\
\hline 0.14 &
\end{tabular}

90.1

Sub-total

$\begin{array}{ll}7 & 0.32\end{array}$

109

0.14

Labri dae

Anampses

Cheilinus bimaculatus

Cheilinus sp.

C. trilobatus

103

C. undul atus

Chelio inermis

0.04

$\begin{array}{lr}15 & 0.67 \\ 9 & 0.4\end{array}$

27

325

0.03

11.5

314

4.61

3183

0.08

75

0.17

Choeradon anchorago

0.71

411

560

0.43

11.9

0.42

11.5

4.32

11.4

0.10

12. 1

0.55

Hal i ocheres

centri quadrus

H. marginatus

0.08

0.75

25.5

1.33

1.36

1.18

0.85

3.42

H. trimacilatus

0.04

76

0.10

13.8

1.05

381

0.05

13.9

0.94

Hemi gymnus

mel apterus

Labrid $A$

C

6
144

0.26

308

0.51

11.9

2. 1

0.42

13.0

1.05

8.62

13.0

11.3

1.2

1.97

1421

0.54

1.92

12.4

1.52

315

0.43

14.8

1.91

Stethojul is

trileneata

0.36

297

0.40

12.0

0.51

Thal assom

0.04

26

0.04

11.6

0.37

14.4

1.12

Sub-total

20.17

Lethrinidae

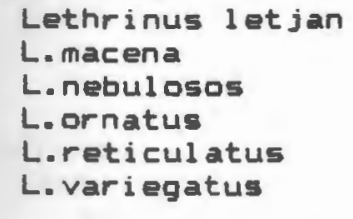

Sub-total
391

17.54

\begin{tabular}{rr}
1 & 0.04 \\
2 & 0.09 \\
3 & 0.13 \\
27 & 1.21 \\
2 & 0.09 \\
15 & 0.67 \\
\hline 50 & -2.24
\end{tabular}

14902

\begin{tabular}{rr}
22 & 0.03 \\
50 & 0.07 \\
109 & 0.15 \\
547 & 0.74 \\
34 & 0.05 \\
332 & 0.45 \\
\hline 1094 & 1.48
\end{tabular}

11.0

11.3

12.6

0.26

13.5

9.9

6.18

12.0

0.65

2.52

Mullidae

Parupeneus barberinus
P.bifasciatus
P. cylindrica
P.trisfaciatus

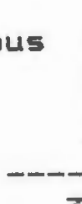

Sub-total

$30 \quad 1.35$

1088

1.47

14.3

1.42

101

0.05

20

118

0.14

14.0

0.62

$\begin{array}{ll}1 & 0.05 \\ 4 & 0.18\end{array}$

0.16

11.6

0.74

1.80 
Nemipteridae

Scal opsis

cancel latus

2

0.09

70

0.09

15.7

1.6

Dstrciontidae

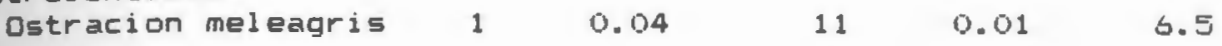

Ponacentridae

Abudefduf 1 eucazonus

A. vaigiensis

Ambl yglyphidodon

cur ac ao

Cromis sp.

Dascyllus aruanus

Eupomacentrus nigricans

Pomacentrus mol uccensis

P.phil ippinus

Pomacentrus 5p.

Stegastes SP.

11

$$
0.01
$$

$$
\text { Sub-total }
$$

19

10.04

10.04

40

0.05

0.03

10.6

20

8. 1

90.85

271

0.37

8.5

10.04

10.04

0.02

8. 1

15

0.01

5.7

1. 17

140.63

606

o. 82

11.5

1.5 .5

0.04

25

0.03

10.7

0.04

0.02

日. 5

0.13

51

0.07

8. 8

5. 90

11.2

0.32 142

183

6. 37

4.363

6.96

Scaridae

Leptoscarus vaigensis

Scarus

capistratoides

S. fasci atus

S. ghobban

S. harak

S. 1 epidus

S. aviceps

S.psittacus

S. rhoduropterus

Scarus sp.

$$
\text { Sub-total }
$$

$\begin{array}{rrrrrr}2 & 0.09 & 230 & 0.31 & 19.3 & 1.55 \\ 6 & 0.27 & 370 & 0.50 & 14.7 & 1.94 \\ 6 & 0.27 & 201 & 0.27 & 11.9 & 0.386 \\ 29 & 1.30 & 1797 & 2.43 & & \\ 15 & 0.67 & 454 & 0.62 & 11.9 & 0.798 \\ 13 & 0.58 & 500 & 0.68 & 12.6 & 1.291 \\ 1 & 0.04 & 154 & 0.21 & 20.9 & \\ 1 & 0.04 & 40 & 0.05 & 12.8 & \\ 152 & 6.82 & 1384 & 1.87 & 12.2 & 1.13 \\ 26 & 1.17 & 5499 & 7.44 & 13.1 & 2.55 \\ -251 & 11.27 & 10629 & 14.39 & & \end{array}$

\section{Scorpaenidae}

Scorpanea sp.

Scorpaenopsis sp

$$
\text { Sub-total }
$$

$\begin{array}{cc}36 & 1.62 \\ 16 & 0.72 \\ -52 & --33\end{array}$

$\begin{array}{cc}1290 & 1.75 \\ 576 & 0.78 \\ ---0- & ---- \\ 1866 & 2.53\end{array}$

12.4

0.125

11.3

0.661

Serranidae

Cephal ophol is

pachycentron

Epinephalus merra

E. summana

Grammi stes

sexlineatus

Sub-total

\begin{tabular}{rrr}
5 & 0.22 & 346 \\
84 & 3.76 & 4216 \\
5 & 0.22 & 315 \\
1 & 0.04 & 20 \\
\hline 95 & 4.43 & 4897
\end{tabular}

0.47
5.71
0.45

14. 5

14.8

2.42

16.2

2.14

0.03

10. 3

6.63 


\section{Siganidae}

Siganus canal i cul atus

S. quttatus

5. javus

Siganus sp.

S. $5 p$ inus

5. virgatus

Sub-total

\section{Zancl idae}

Zanclus cornutus

Total

\begin{tabular}{rr}
87 & 3.90 \\
2 & 0.09 \\
5 & 0.22 \\
1 & 0.04 \\
931 & 41.78 \\
11 & 0.49 \\
\hline 1037 & 46.54
\end{tabular}

$7 \quad 0.31$

$2228 \quad 100 \%$

\begin{tabular}{rr}
2928 & 3.96 \\
115 & 0.16 \\
229 & 0.31 \\
30 & 0.04 \\
27685 & 37.46 \\
232 & 0.31 \\
\hline 31219 & 42.24
\end{tabular}

13.4

15. 3

16.2

11.8

11.9

10.4

2.6

0.5

1.74

$\frac{2}{2}$

$120 \quad 0.16$

8.2

0.72

$73880 \quad 99.62 \%$ 
Appendix 5

Catch composition for trap fishery 1 nside a coral reef lagoon.

Cape Bolinao, Fhilippines.

in:

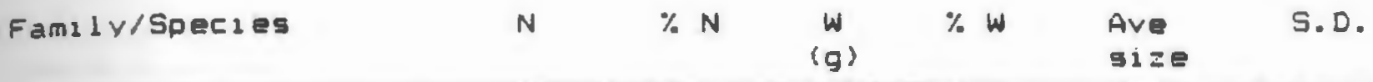

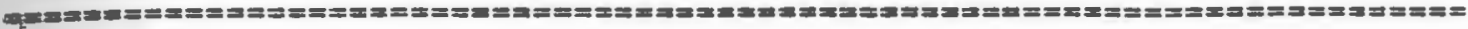

Acanthuridae

Acanthurus sp.

Ctenochaetus

striatus

Naso sp.

Zebrasoma scopas

Sub-total

$\begin{array}{rr}4 & 0.20 \\ 5 & 0.24 \\ 3 & 0.15 \\ 4 & 0.20 \\ -16 & -0.78\end{array}$

\begin{tabular}{cl}
161 & 0.30 \\
99 & 0.18 \\
60 & 0.11 \\
33 & 0.06 \\
\hline 353 & 0.65
\end{tabular}

12.2

3.40

10.

1.39

5.6

2. 43

$16 \quad 0.78$

Is

1. 24

Apogonidal

Apogon bandenensis

Apogon fraenatus

Apogon Sp.

$\begin{array}{cc}12 & 0.59 \\ 3 & 0.15 \\ 85 & 4.15 \\ -100 & -4.89\end{array}$

$\begin{array}{r}51 \\ 251 \\ 1641 \\ \hline 1943\end{array}$

0.09

0.46

10.8

0.60

251

3.05

sub-total

4. 89

3.60

Balistidae

Balistapus sp.

Bal i etapue

undul atus

Balistes A

Balistes ep.

Rhinecanthus

acul eatue

Stephanol yeis

japoni cus

S.tomentoous

Sub-tota 1

0.05

41

0.08

12. 7

$30 \quad 1.47$

822

1. 52

0.55

1. 17

299

35

0.06

9.9

8. 4

1.60

40.20

7.2

0.72

1

0.05

182

0.34

19.4

14

0.68

180

0.33

0.52

8. 4

0.04

10

1.43

24

1. 17

279

$----$

8. 3

0.76

9

4. 79

1838

3.40

Blenni idae

Sal arias

fasei atus

Salarias sp.

3
---5
-5

Sub-total

0.15

$\begin{array}{cc}60 & 0.11 \\ 75 & 0.14 \\ -1.35 & 0.25\end{array}$

10.9

1.51

2

0.10

0.22

135

13.8

0.95

\section{Chaetodont 1 dae}

Chaetodon auriga

C. citrinellus

C. mel anotus

c. octofasciatus

C. oxyeophalus

C. punctatofasiatus

C. trisfaciatus

Sub-total

$\begin{array}{rr}10 & 0.49 \\ 1 & 0.05 \\ 2 & 0.10 \\ 1 & 0.05 \\ 1 & 0.05 \\ 2 & 0.10 \\ 2 & 0.10 \\ -19 & -0.93\end{array}$

$\begin{array}{r}66 \\ 9 \\ 13 \\ 10 \\ 6 \\ 15 \\ 31 \\ \hline 150\end{array}$

0.12
0.02
0.02
0.02
0.01
0.03
0.06
0.0 .28

6.3

1.07

7.40

6.9

0.50

6. 4

5.2

7.6

1. 40

8

0.25 
Haenul 2 dae

Plector 1 vnchus dz agr ammus

P. 1 ineatus

Sub-total

$\begin{array}{cl}4 & 0.70 \\ -7 & 0.15 \\ -7 & 0.34\end{array}$

$\begin{array}{cll}114 & 0.18 & 12.6 \\ 72 & 0.13 & 11.6 \\ -186 & 0.72 & \end{array}$

1.25

1. $9 i^{\circ}$

Hol ocentridae

Adz oryx ruber

Adioryx sp.

Flammeo sammara

Myripristis murdjan

$\begin{array}{cc}1 & 0.05 \\ 2 & 0.10 \\ 3 & 0.15 \\ 1 & 0.05 \\ -7 & --0.34\end{array}$

\begin{tabular}{rl}
27 & 0.05 \\
105 & 0.19 \\
85 & 0.16 \\
33 & 0.06 \\
\hline 250 & 0.46
\end{tabular}

12

Sub-total

0.34

14

12.6

11.7

10.55

0.61

Labr 2 dae

Chellinus bimaculatus

c. fasciatus

Cheilinus sp.

2. 25

1022

50

0.10

23

C. Tril obatus

4. 34

807

3171

0.05

90

723

Choerodon anchorago

$24 \quad 1.73$

Cirrhilabrus ep.

0.29

223

$$
\begin{aligned}
& 1.90 \\
& 0.09 \\
& 1.50 \\
& 5.88 \\
& 0.17 \\
& 1.34 \\
& 0.41
\end{aligned}
$$

12. 4

0.85

11.2

0.25

11.4

2.07

1.54

1.44

Hal I choeres

$$
\text { marginatus }
$$

H. scapul aris

H. trimaculatus

0. 05

29

0.05

0.08

D. 05

45

0.11

26

11.8

13.5

0.32

Hemi gymnus

mel apterus

Labrid $A$

B
C

Labrid sp.

Stethojulis

tri l eneata

Thal assoma

hardwicke

sub-total

0.10

42

0.08

4290

7.94

0.25

0.20

136

3.38

3.08

1820

0.47

251

2.74

12.6

13.4

12.6

0.55

0.44

1479

9.9

0.40

12.6

1.25

12.3

0.37

11.1

1.52

10.9

1.36

11.7

0.90

10.05

30

0.06

11.6

$\frac{6}{445} \quad \frac{0.29}{21.74}$

$\frac{266}{14531}$

0.49

12.8

3.35

Lethrinidae

Lethrinus

ornatus

L.rhodopterus

Lethrinus sp.

L.variegatus

47
1
5
-5

Sub-total

131
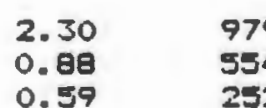

979
554
252

1.82

1.03

10.4

1.34

$18 \quad 0.89$

1071

0.47

11.6

10.7

3.48

20.59

1.99

10.6

1.04

28965

\section{Lutjanidae}

Lut janus

ful viflamma

0.15

166

0.31

15.7

1.91 
Mull ldae

Farupeneus bandanensis

Parupeneus barberinus 29

$P$. indicus

P.trisfaclatus

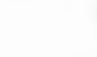

Sub-total

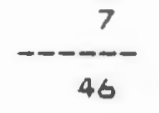

$$
\begin{aligned}
& 0.39 \\
& 1.42 \\
& 0.10 \\
& 0.34
\end{aligned}
$$

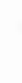

267
926
72
181
$--0-$

0. 50

1. 72

0. 13

0. 34

2.68

Nemipteridae

Pentapodus sp.

Scalopsis

cancel l atus

Sub-total

$\begin{array}{rr}1 & 0.05 \\ -6 & 0.29 \\ -7 & 0.34\end{array}$

31

0.37

12.7

13.5

1. 13

1.7

12. 8

. 0.3

1.00

0.90

Dstrciontidae

ostracion cubicus

10.05

$-\frac{200}{251}$

0.37

9.5

3.54

Pomacanthidae

Contropyge wrol iki

Ponacanthus

semicirculatur

Sub-total

$\begin{array}{rr}1 & 0.05 \\ -1 & 0.05 \\ -2 & 0.10\end{array}$

13

41

0.08

10.5

Pomacentridae

Abudefduf

1 eucazonus

Amblyglyohidodon aur eus

A. curacao

Daseyllus aruanu

D. trimaculatus

Di schistodus

chrvposilus

Eupomacentrus nigricans

Plectroglyphidodon lacrymatus

Pomacontrus rotopthalmus

Pomacontrus sp.

Stegaetes sp.

\section{Sub-total}

2

637

1.18

10

1.93

10.05

0. 39

10

0.02

0.33

0.14

0.05

$\begin{array}{rr}8 & \\ 10.1 & 0.50 \\ 6.3 & 0.32 \\ 9.3 & \end{array}$

90.44

76

29

9.3

972

1. 80

11

1. 42

5

101

0.19

9.5

1.00

3

0.15

30

0.06

7.5

0.29

1

3

0.68

356

$$
0.15
$$

113

0.66

10.3

1. 75

6. 21

2637

0.21

12. 4

1.00

4.88

10. 9

1. 36

9.53

\section{Plotosidae}

Plotosus

anguil1 aris

1

0.05

76

0.14

22.6 
Scars dae

Calotomus spinidens

Leptoscarus valgensis

Scarus

cap 3 stratoides

5. fasclatus

5. ghobban

S. Iepl dus

S.psittacus

S. rhoduropterus

S. sc aber

S. spinideus

Scarus sp.

$$
\text { Sub-total }
$$

$\begin{array}{rr}2 & 0.10 \\ 1 & 0.05 \\ 1 & 0.05 \\ 9 & 0.44 \\ 22 & 1.08 \\ 1 & 0.05 \\ 14 & 0.68 \\ 124 & 0.06 \\ 2 & 0.10 \\ 1 & 0.05 \\ 19 & 0.93 \\ -196 & -9.58\end{array}$

$\begin{array}{rr}69 & 0.13 \\ 56 & 0.10 \\ 43 & 0.08 \\ 227 & 0.42 \\ 1164 & 2.16 \\ 25 & 0.05 \\ 840 & 1.56 \\ 3736 & 6.93 \\ 42 & 0.08 \\ 140 & 0.26 \\ 717 & 1.33 \\ --1-- & ---0--- \\ 7039 & 13.09\end{array}$

1…2

0.85

15.7

15.6

11.5

13.3

11.4

14. 9

11. 8

10.?

18. 4

12.3

i. 77

2.60

1. 4.3

1.05

1. 72

Scorpaenidae

Scorpanea sp.

Scorpaenopsis sp

Sub-total

$\begin{array}{cc}6 & 0.29 \\ 2 & 0.10 \\ -8 & -0.39\end{array}$

$\begin{array}{cc}211 & 0.39 \\ 23 & 0.04 \\ -234 & ---0- \\ 234 & 0.43\end{array}$

11. 5

.0 .91

11.4

2.25

Serranidae

Cephat opholis argus

C. pachycentron

Cephalophosis sp

Epi nephalus macrospil us

Epinephalue merra

E. microdon

E. summana

Sub-total

$\begin{array}{rr}1 & 0.05 \\ 4 & 0.20 \\ 3 & 0.15 \\ 1 & 0.05 \\ 189 & 9.24 \\ 1 & 0.05 \\ 15 & 0.73 \\ --21- & --2- \\ 214 & 10.46\end{array}$

$\begin{array}{rl}79 & 0.15 \\ 133 & 0.25 \\ 137 & 0.25\end{array}$

16.3

12. 1

13

1.21

0.68

$\begin{array}{rr}136 & 0.25 \\ 6688 & 12.40 \\ 28 & 0.05 \\ 774 & 1.43 \\ -7975 & 14.78\end{array}$

20.6

13.7

12. 7

2.94

14.3

2.00

Si ganidae

Siganus

canal i culatus

S. guttatus

S. spịnus

S. variegatue

S.virgatus

Sub-total

\begin{tabular}{rr}
160 & 7.82 \\
3 & 0.15 \\
306 & 14.95 \\
3 & 0.15 \\
35 & 1.71 \\
\hline 507 & 24.77
\end{tabular}

$\begin{array}{r}3143 \\ 64 \\ 5351 \\ 40 \\ 488 \\ \hline 9086\end{array}$

3.83

0.12

9.93

0.07

0.91

-

Synodontidae

Sarida gracilis

10.05

51

0.09

19.3

Tetraodontidae

Tetraodon

ni gropunctatus

10.05

65

0.12

13.5

Zanclidae

Zanclus cornutus

36

0.66

8.5

$\begin{array}{rl}11.4 & 1.80 \\ 10 & 1.53\end{array}$

$10.6 \quad 2.05$

9.11 .59

9.51 .00

Total 
APPENDIX 6

6A. Length-frequency distribution of Siganus spinus by location and comparison between locations. June-December 1986.

$6 B$. Length-frequency distribution of Siganus canalílculatus by location and comparison between locations. June-December 1986.

6C. Length-frequency distribution of Sçarus rhodo locations. June-December 1986.

6D. Length-frequency distribution of Labrid $\underline{A}$ by location and comparison between locations. JuneDecember 1986.

6E. Length-frequency distributionof sttagastes $\mathbf{s} p$. by location and comparison between locations. June-December 1986.

6F. Length-frequency distribution of Cheilinus trilobatus by location and comparison between locations. June-December 1986.

6G. Length-frequency distribution of Epinephalus merra by location and comparison between locations. June-December 1986.

$6 \mathrm{H}$. Length-frequency distribution of Apogon sp. by location and comparison between locations. JuneDecember 1986. 


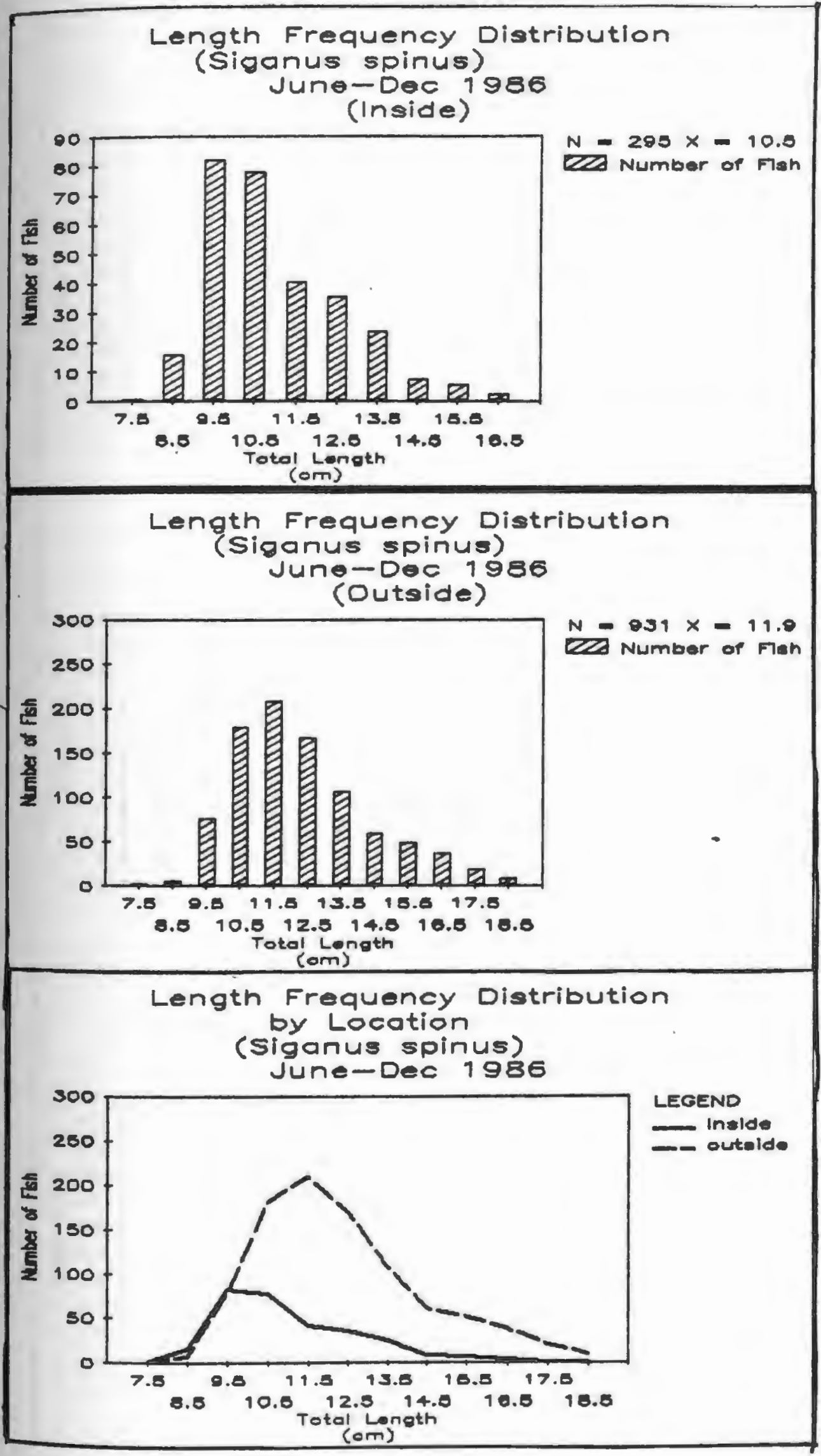




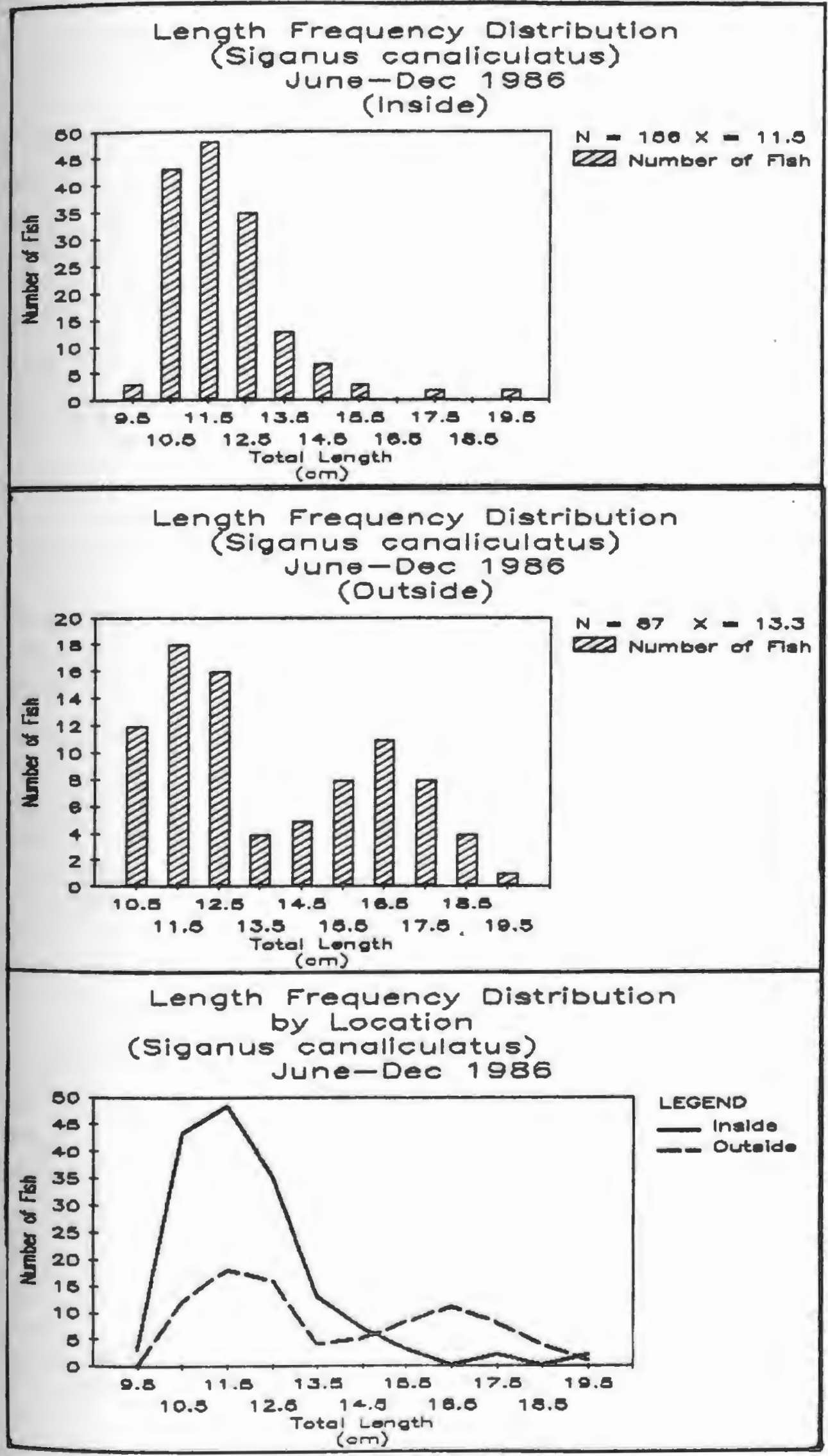




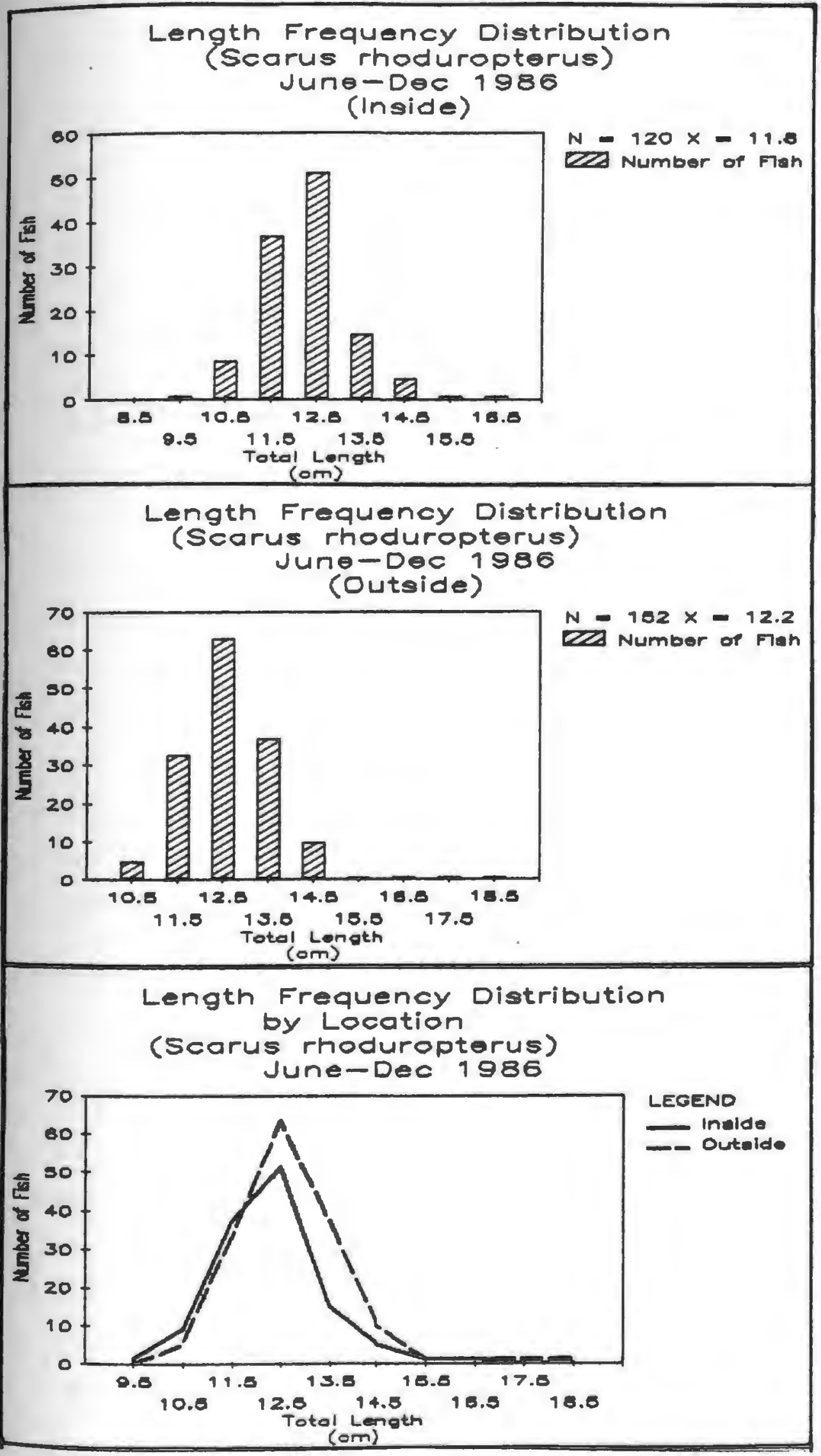




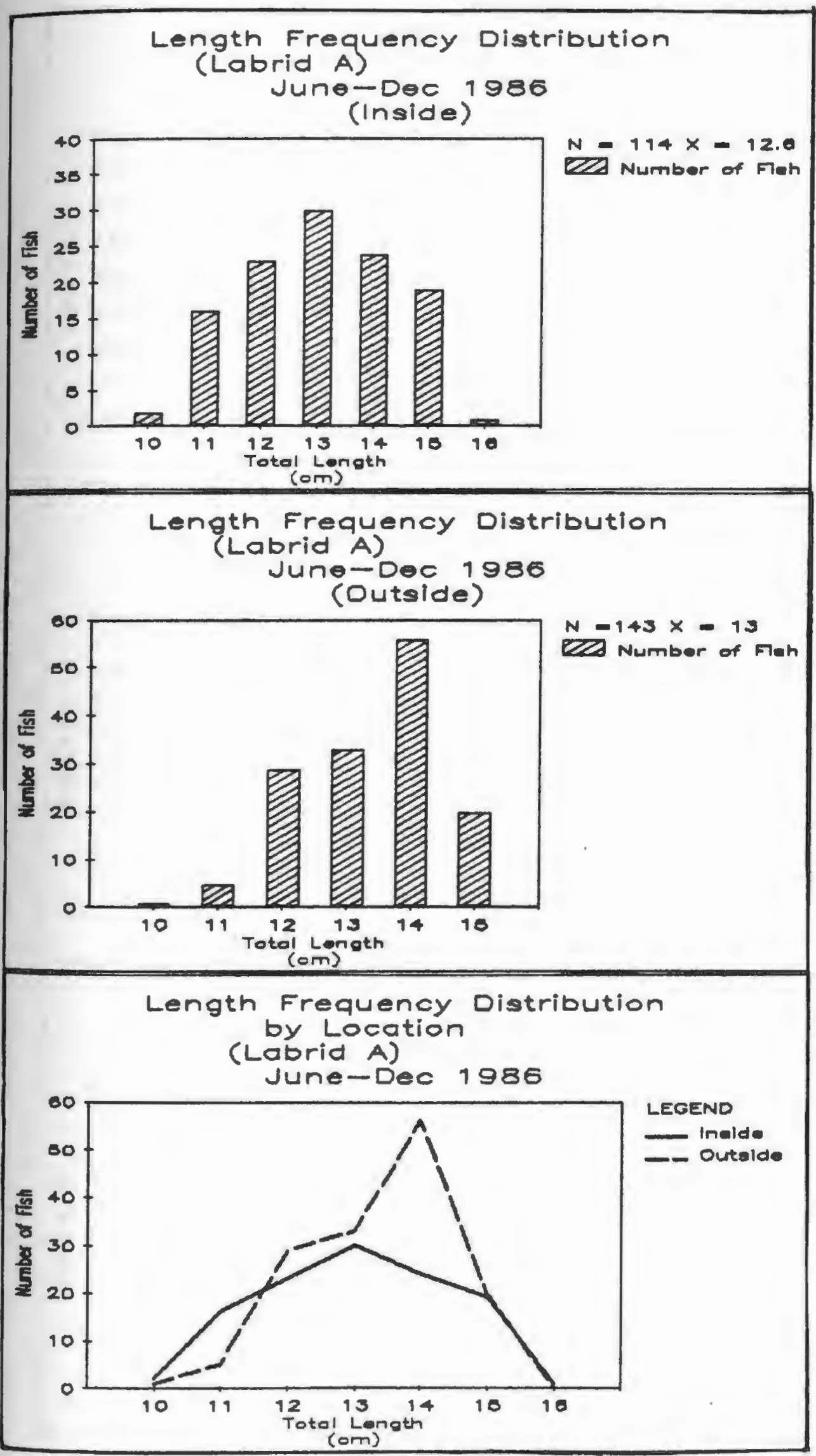




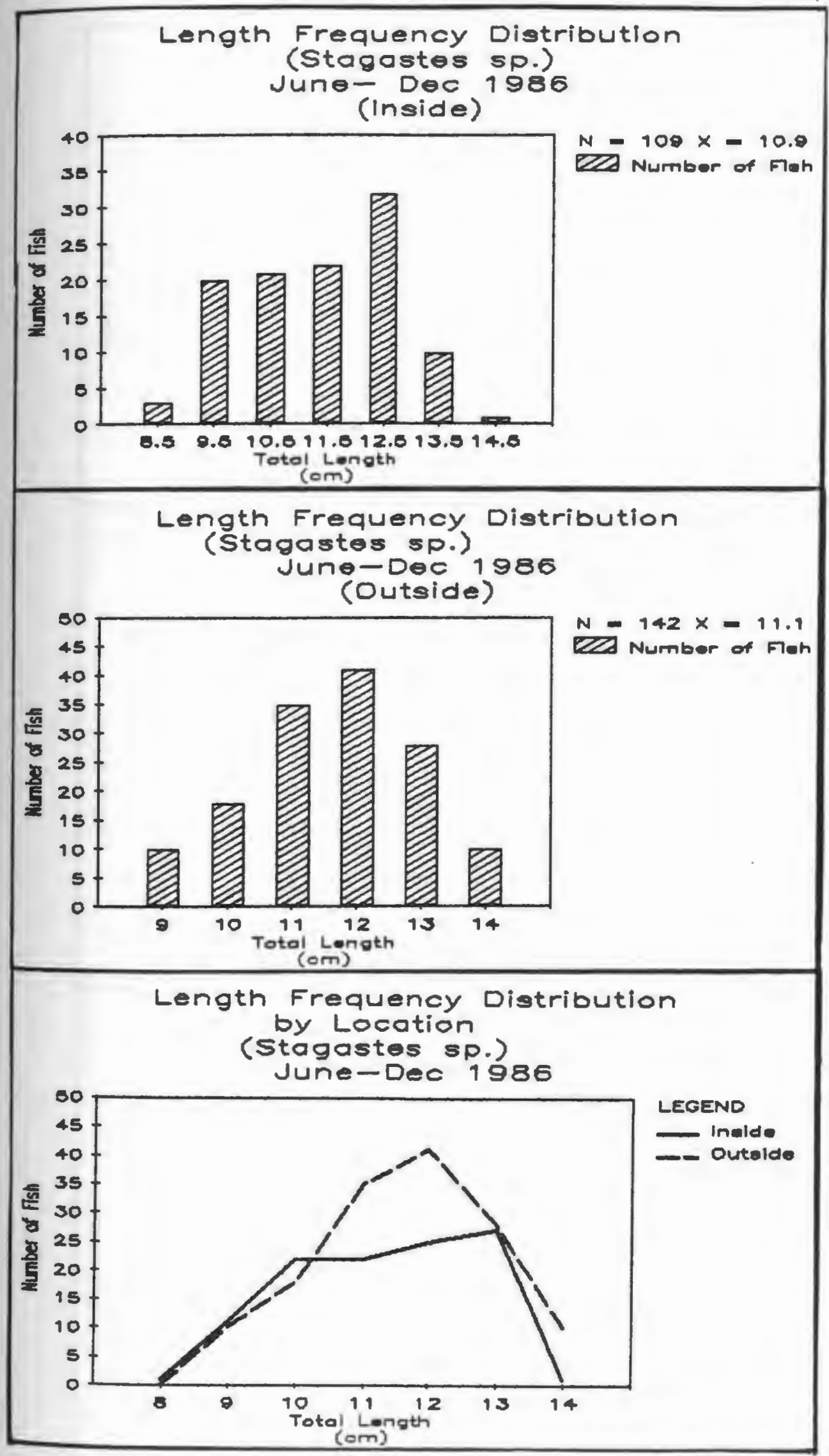




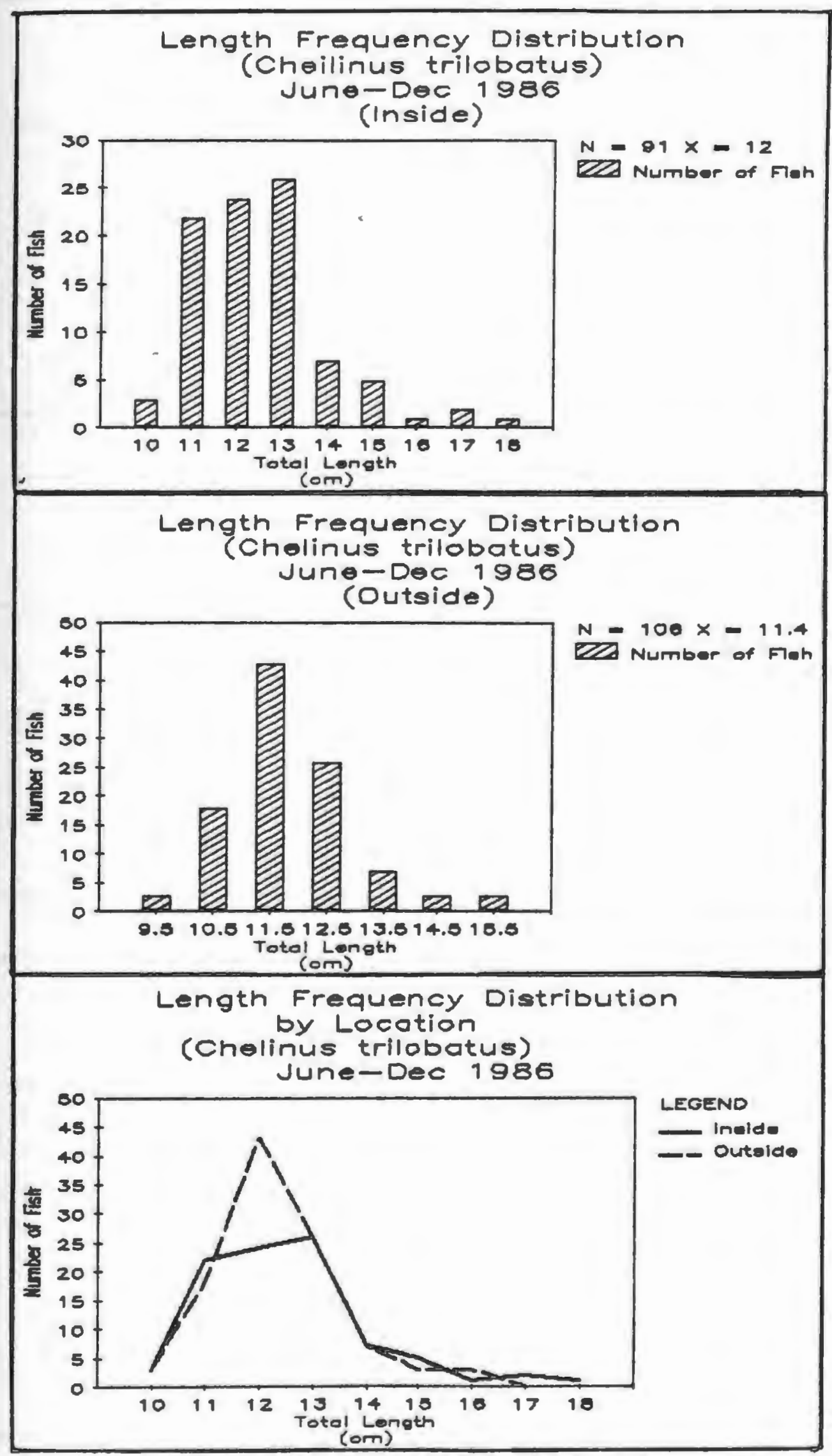




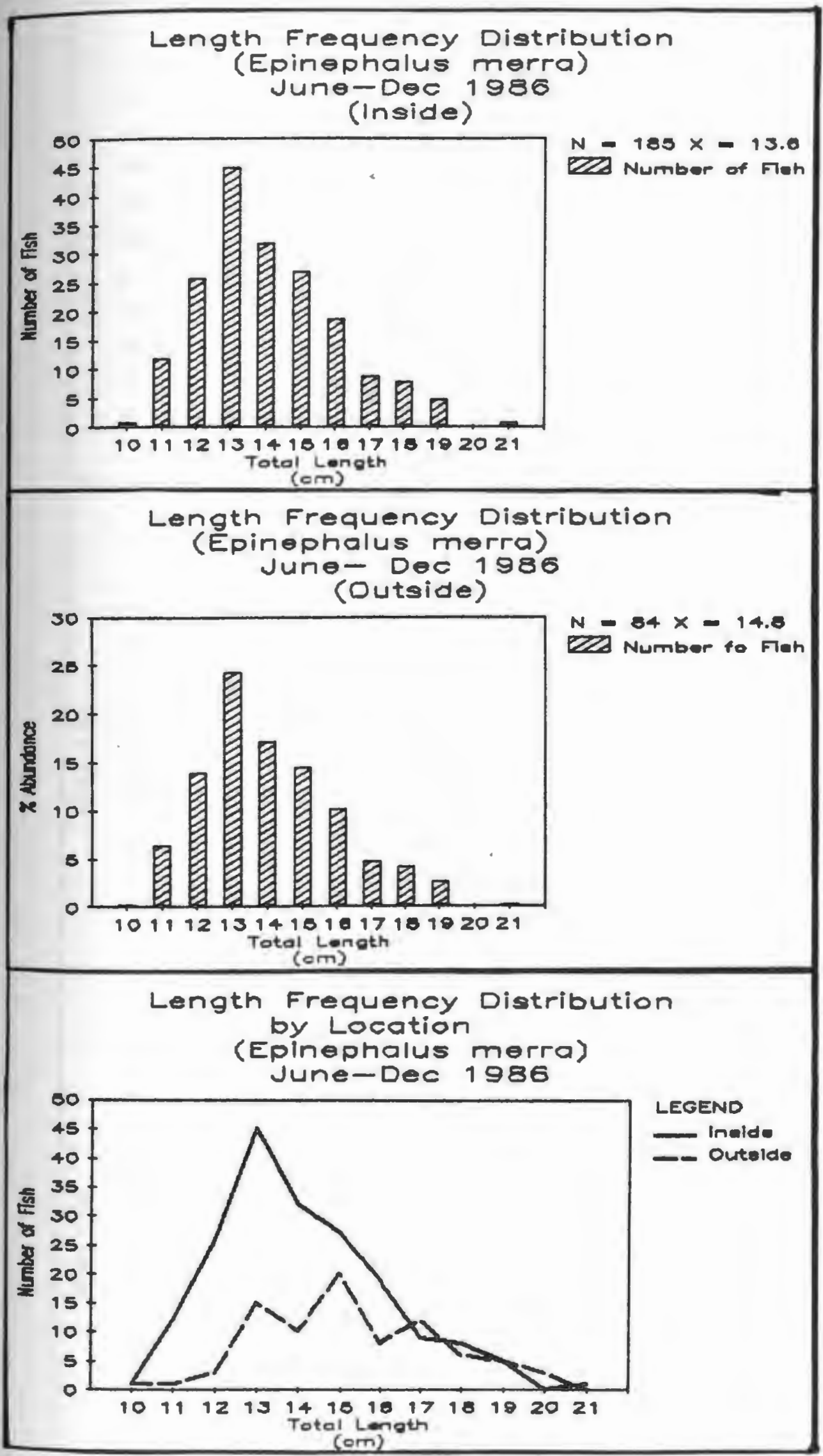




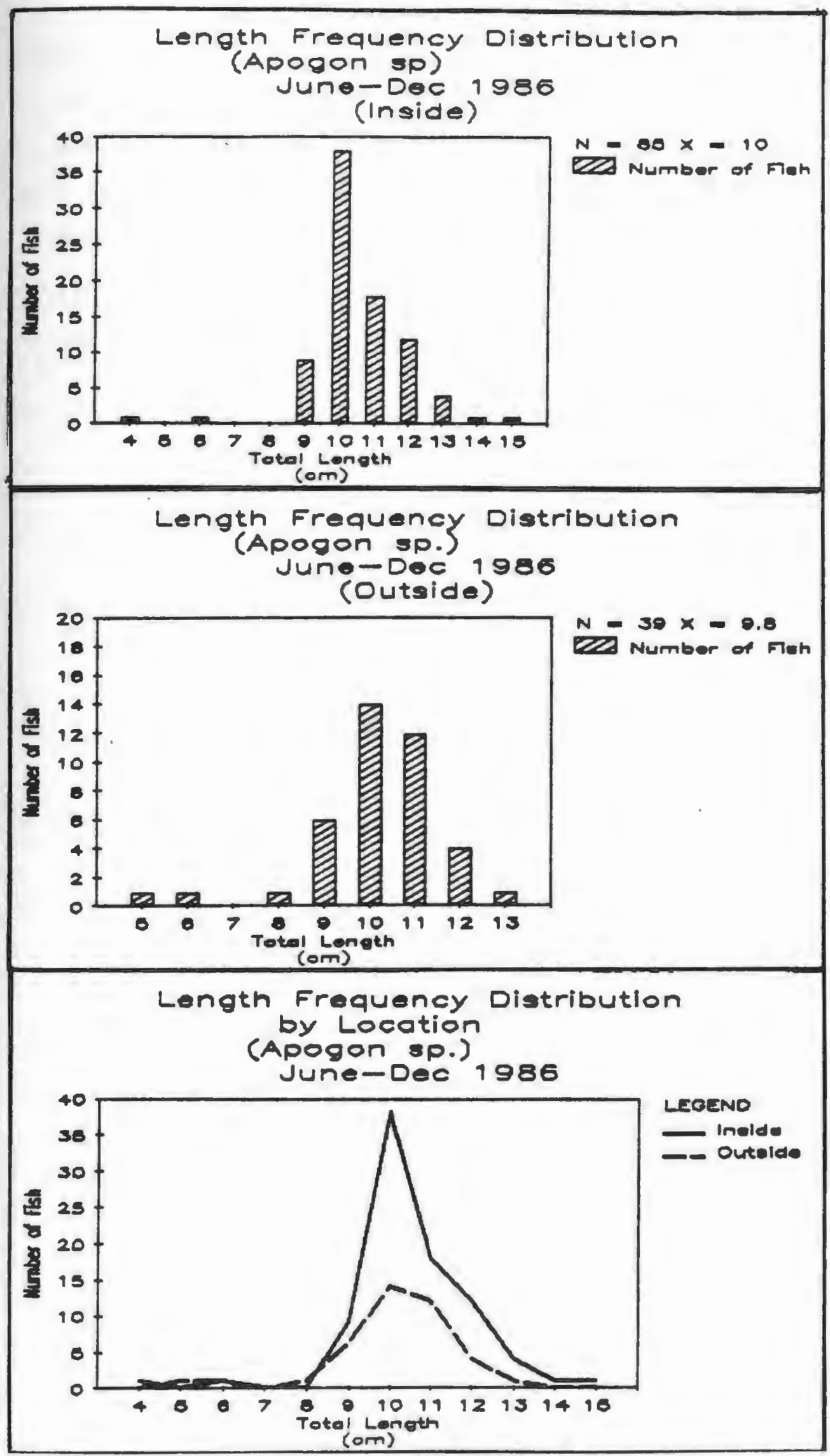




\section{APPENDIX 7}

7A. Length-weight relationship for Siganus spinus June-December 1986.

7B. Length-weight relationship for Siganus

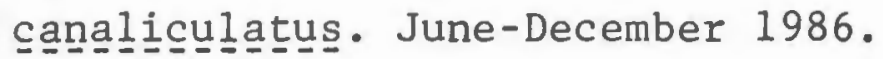

7C. Length-weight relationship for Scararus rhoduropterus. June-December 1986.

7D. Length-weight relationship for Labrid A. JuneDecember 1986.

$7 E$. Length-weigth relationship for Stagastes sq. June-December 1986.

7F. Length-weight relationship for Cheilinus tríliobatus. June-December 1986.

7G. Length-weight relationship for Epinephalus merrsa. June-December 1986.

7H. Length-weight relationship for Apogon sp. JuneDecember 1986. 


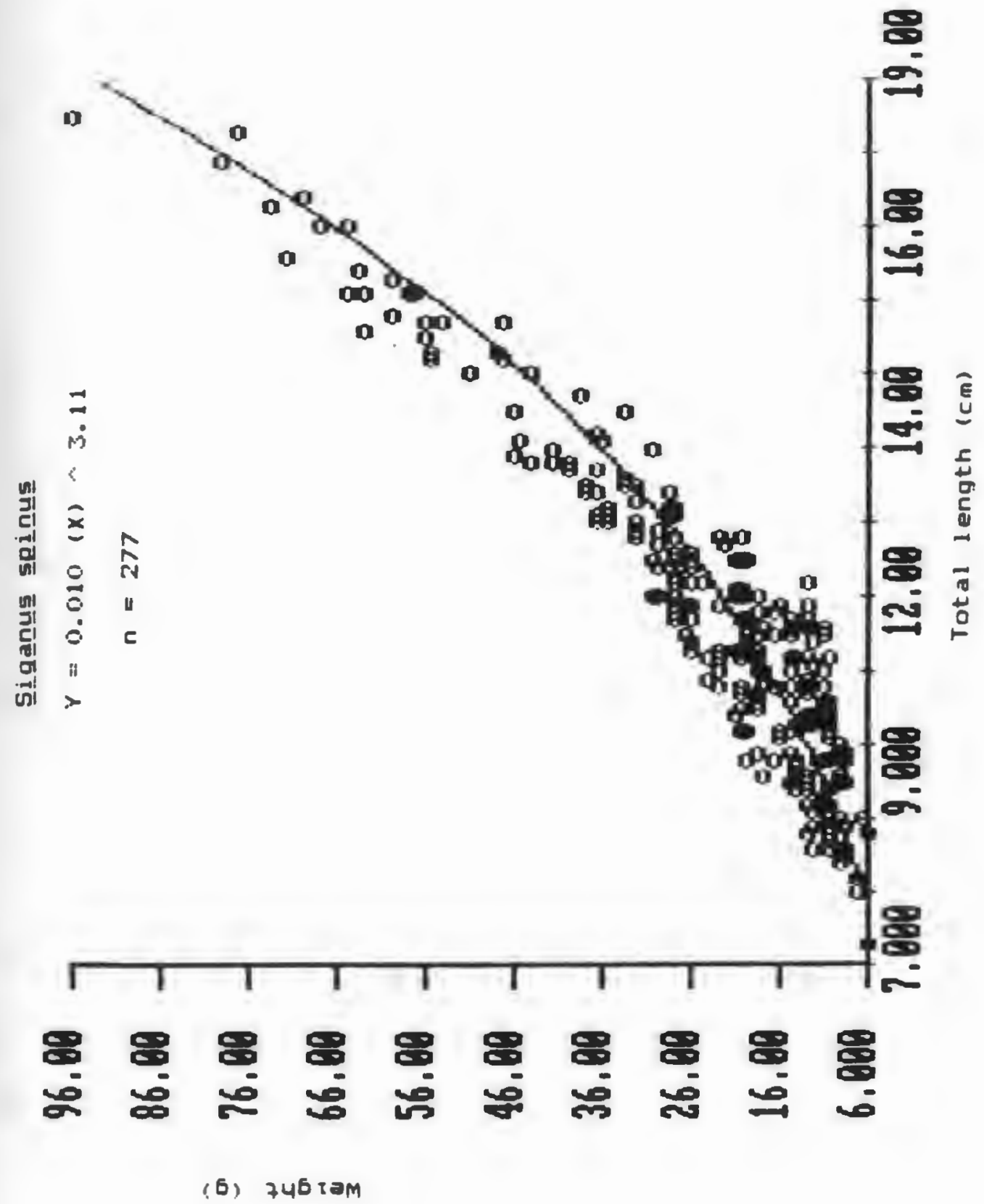




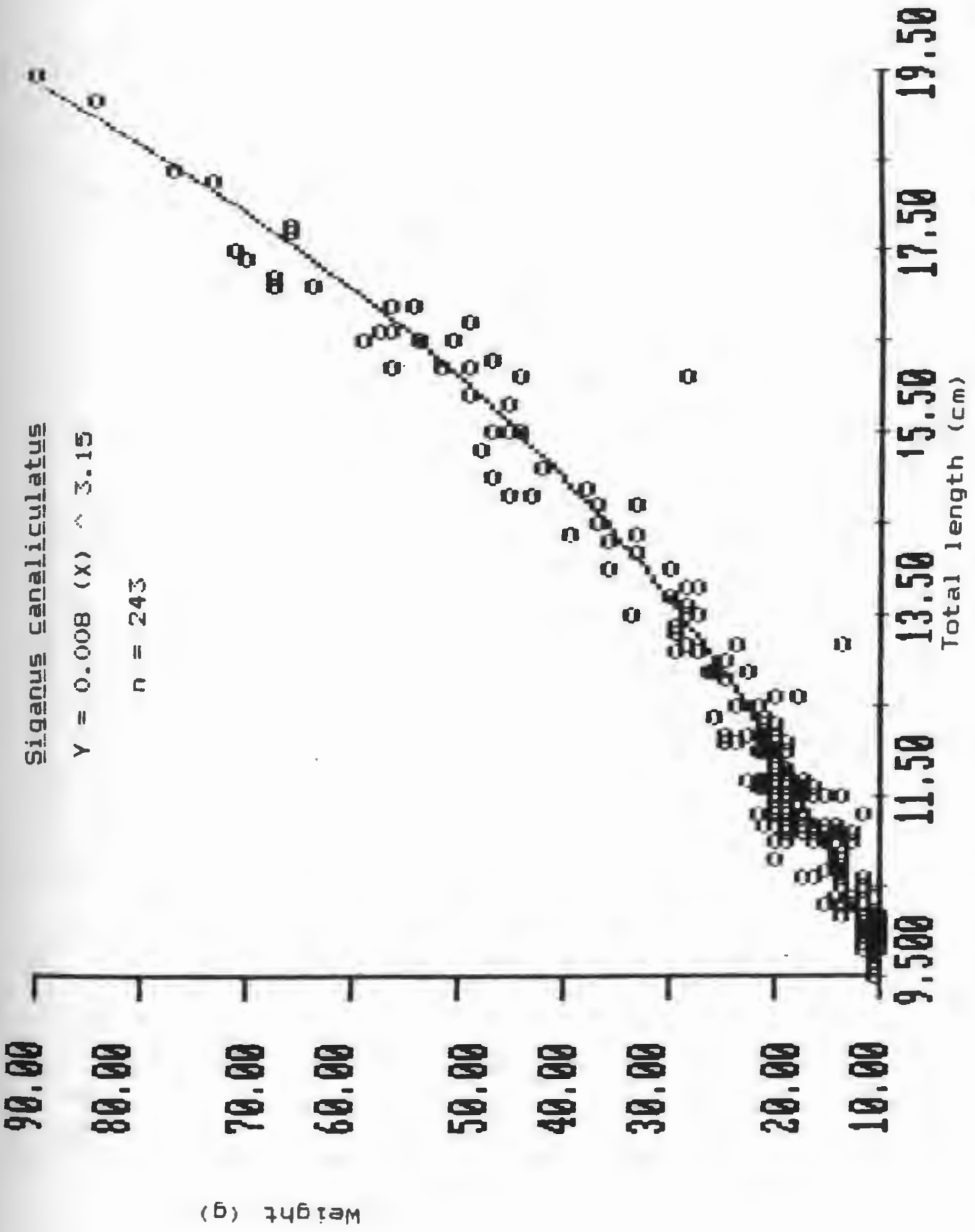




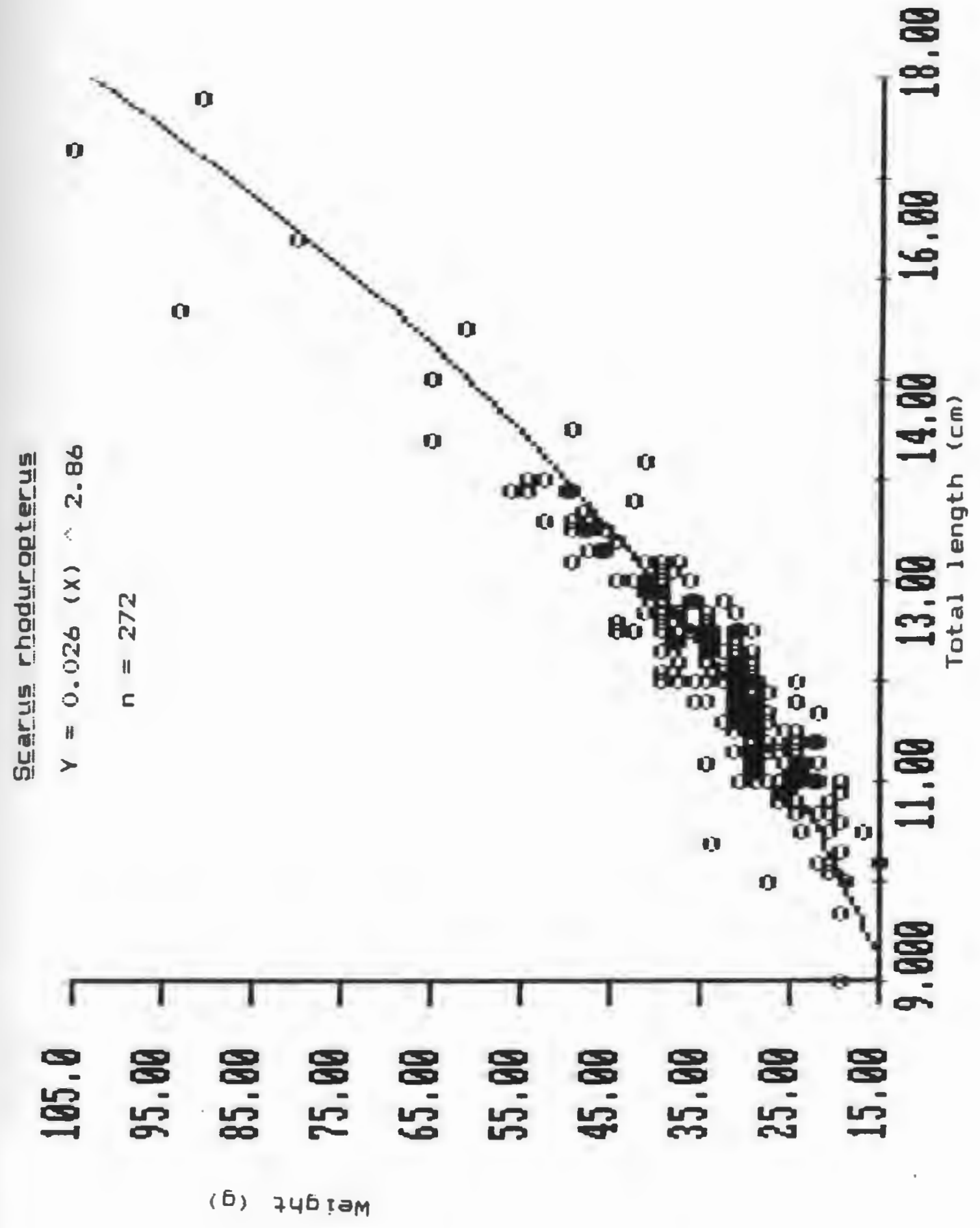




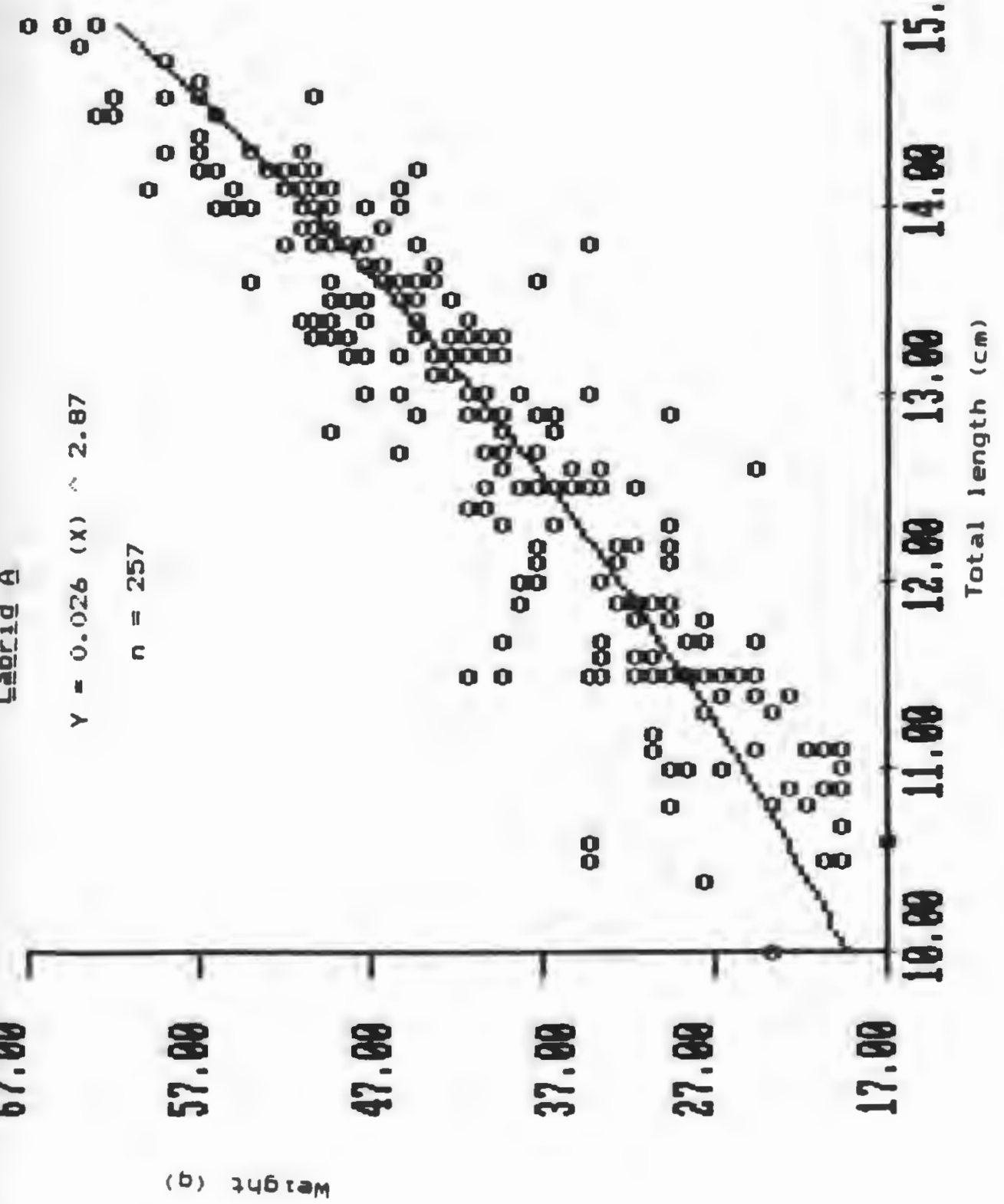




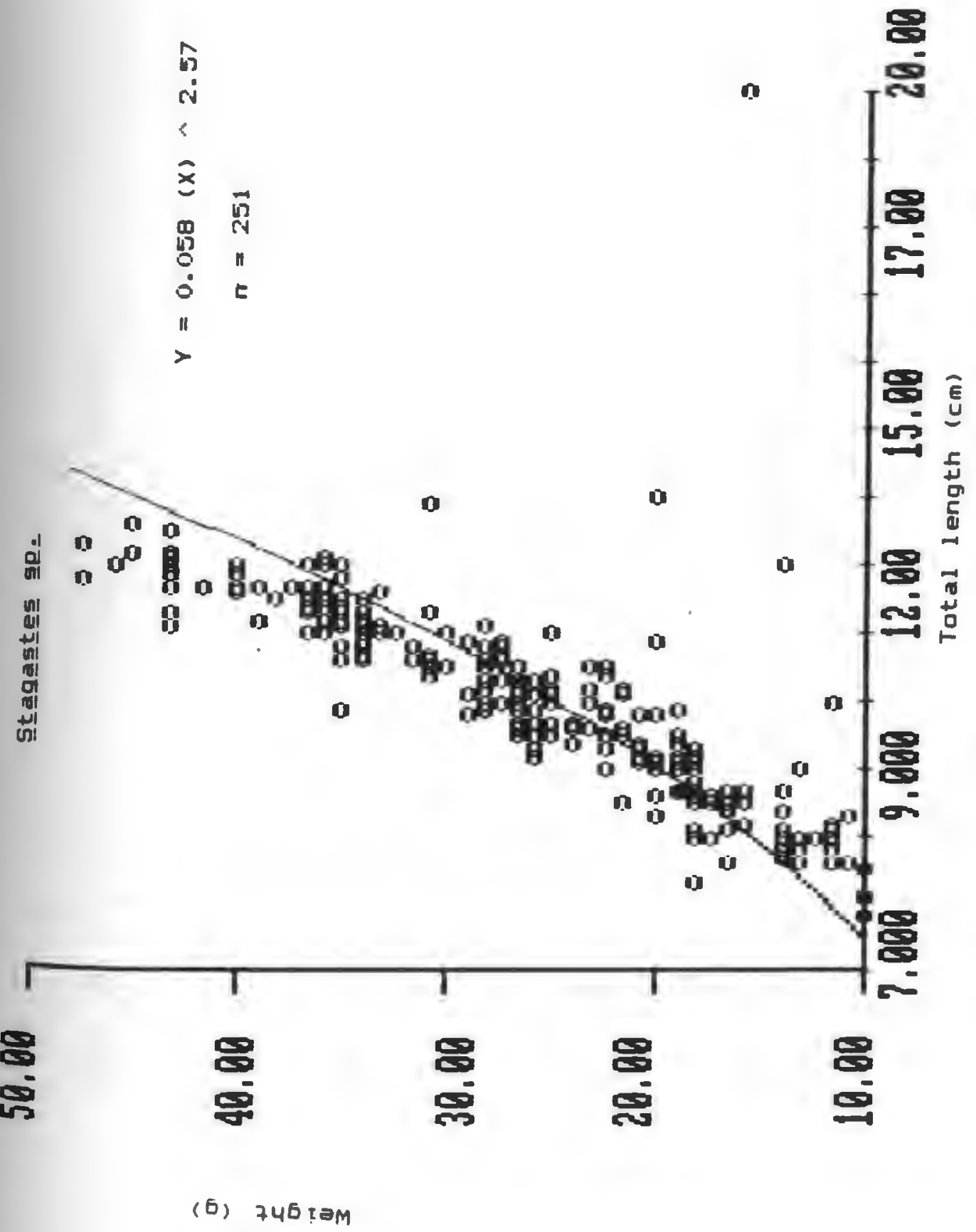




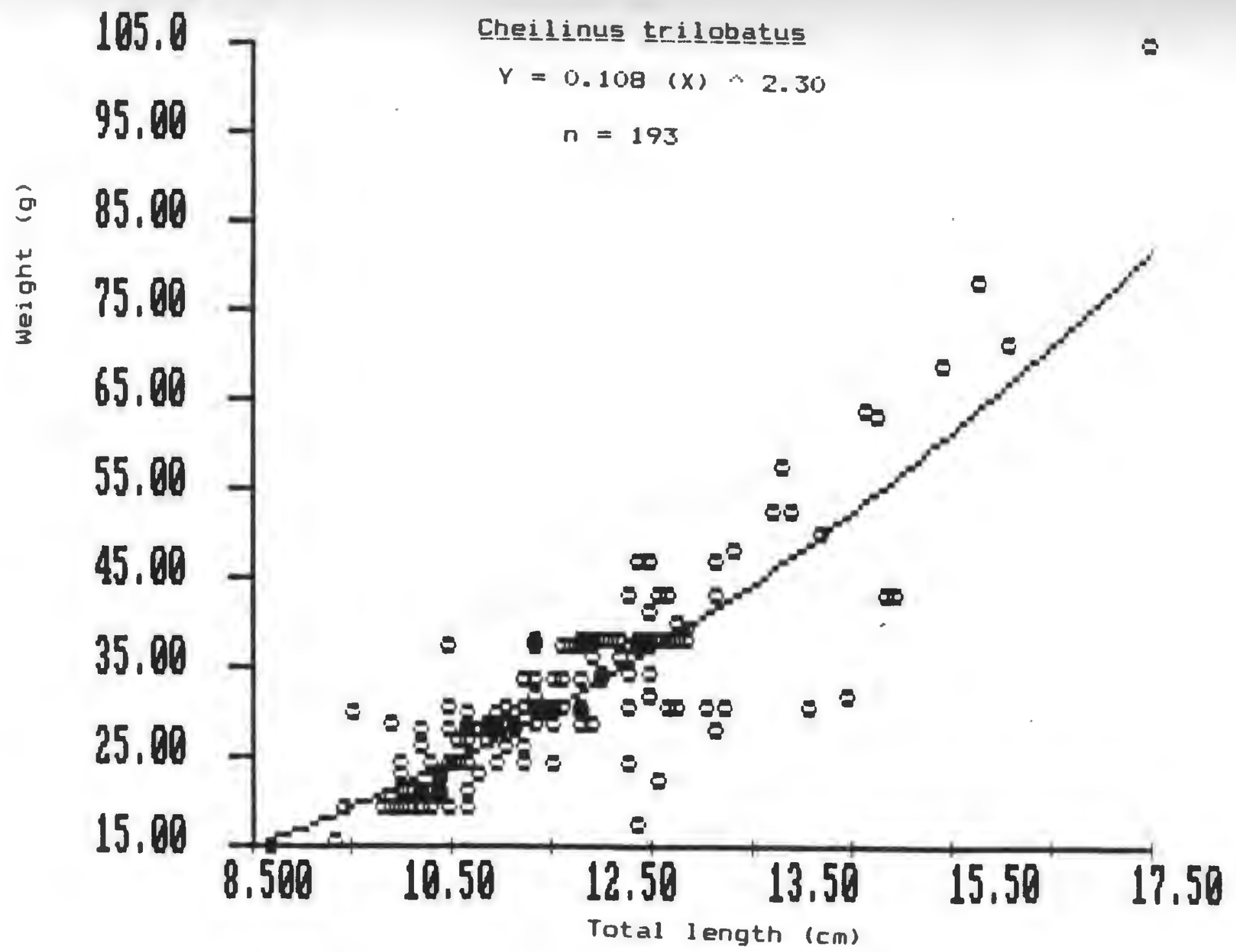




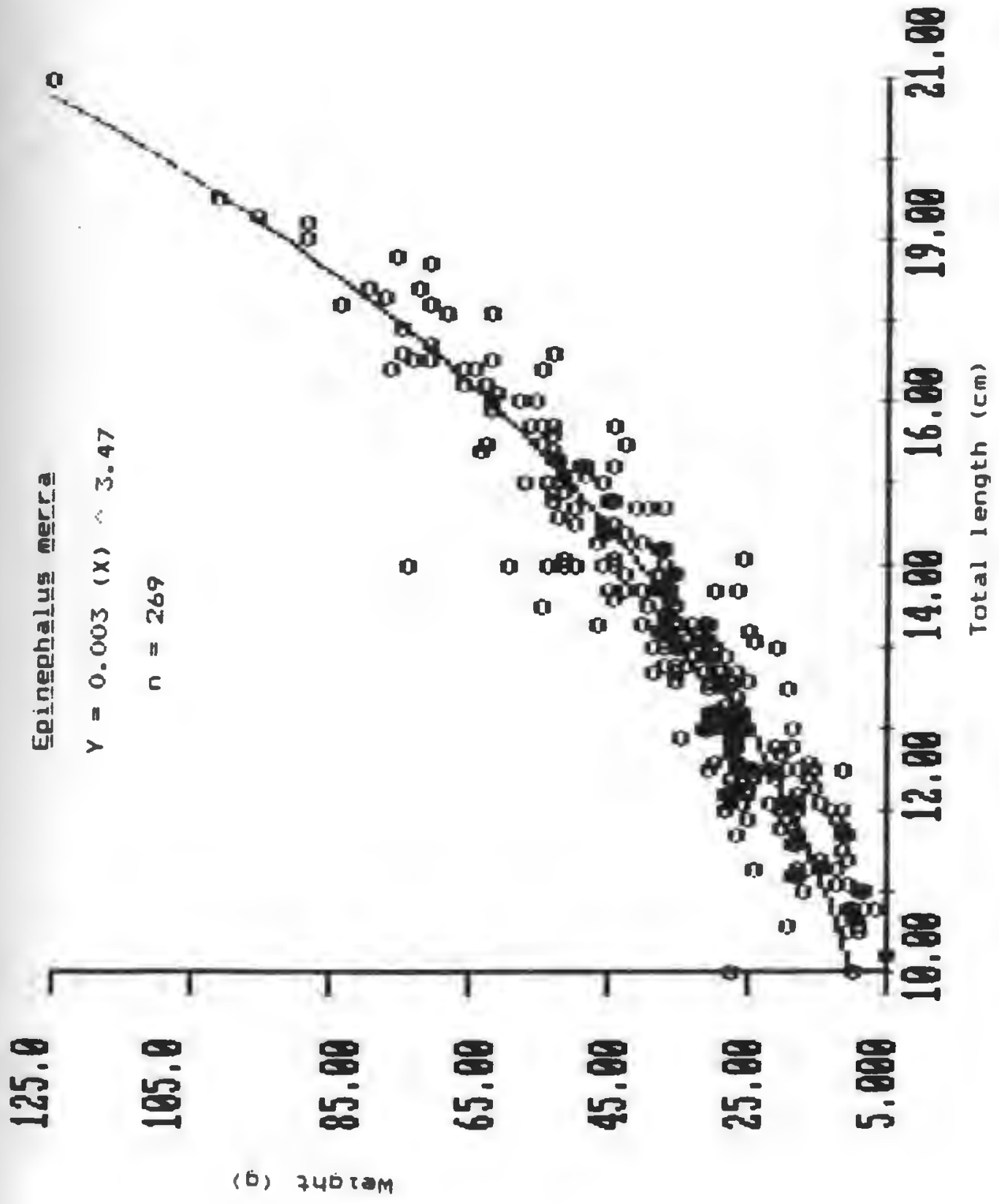




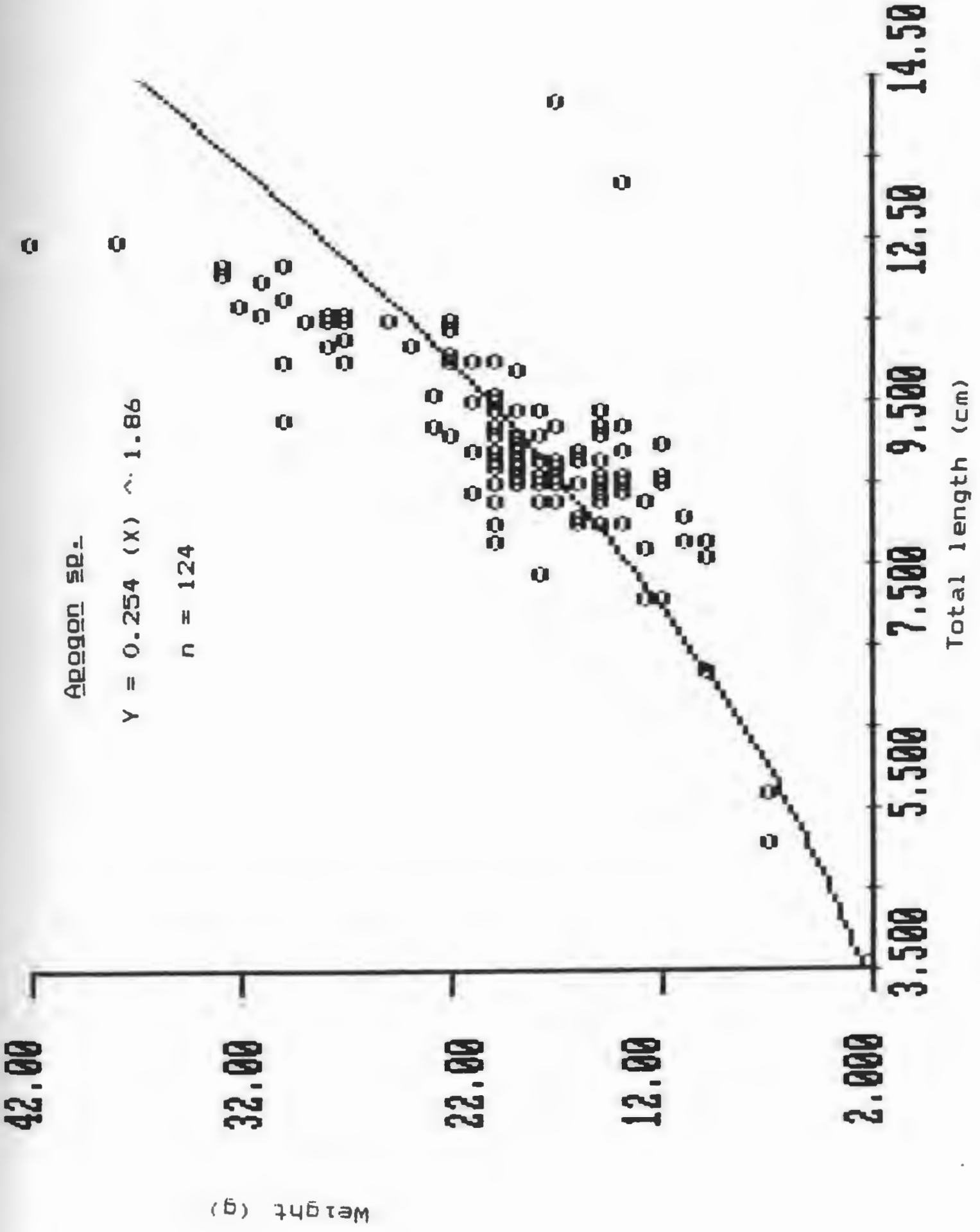


Appendix 8

Species composition for the hook-and-line fishery Cape Bolinao. Philippines

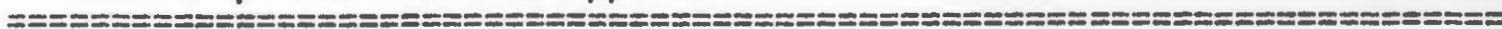

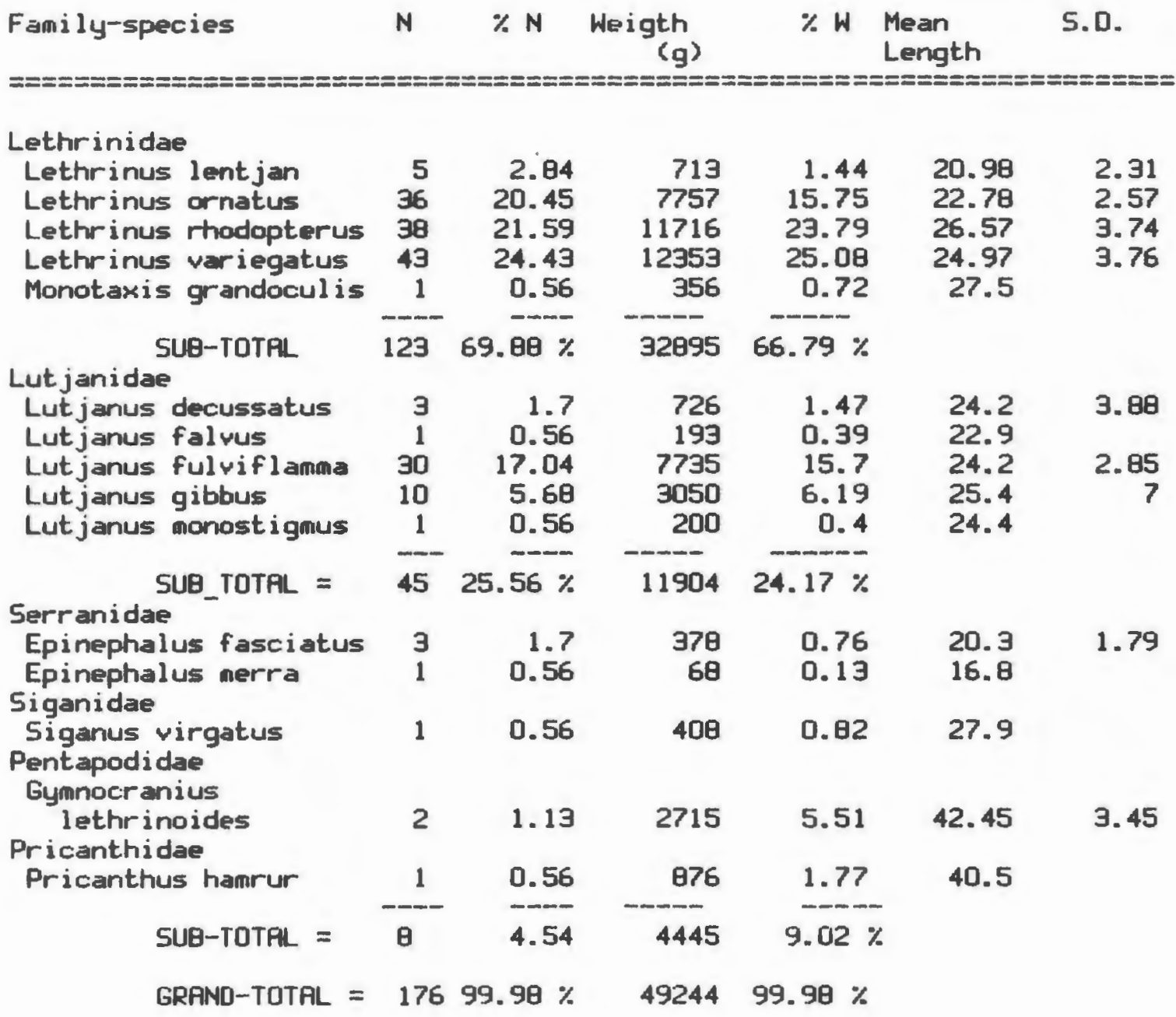


APPENDIX 9

$9 A$. Length-frequency distribution for Lethrinus rhodopterus caught by hook-and-linë.

9B. Length-frequency distribution for Lethrinus variegatus caught by hook-and-line.

9C. Length-frequency distribution for Lethrinus ornatus caught by hook-and-line.

9D. Length-frequency distribution for Lutjanus fulv vif lamma caught by hook-and-linē.

9E. Length-frequency distributionfor Lutjanus gibbus caught by hook-and-line. 


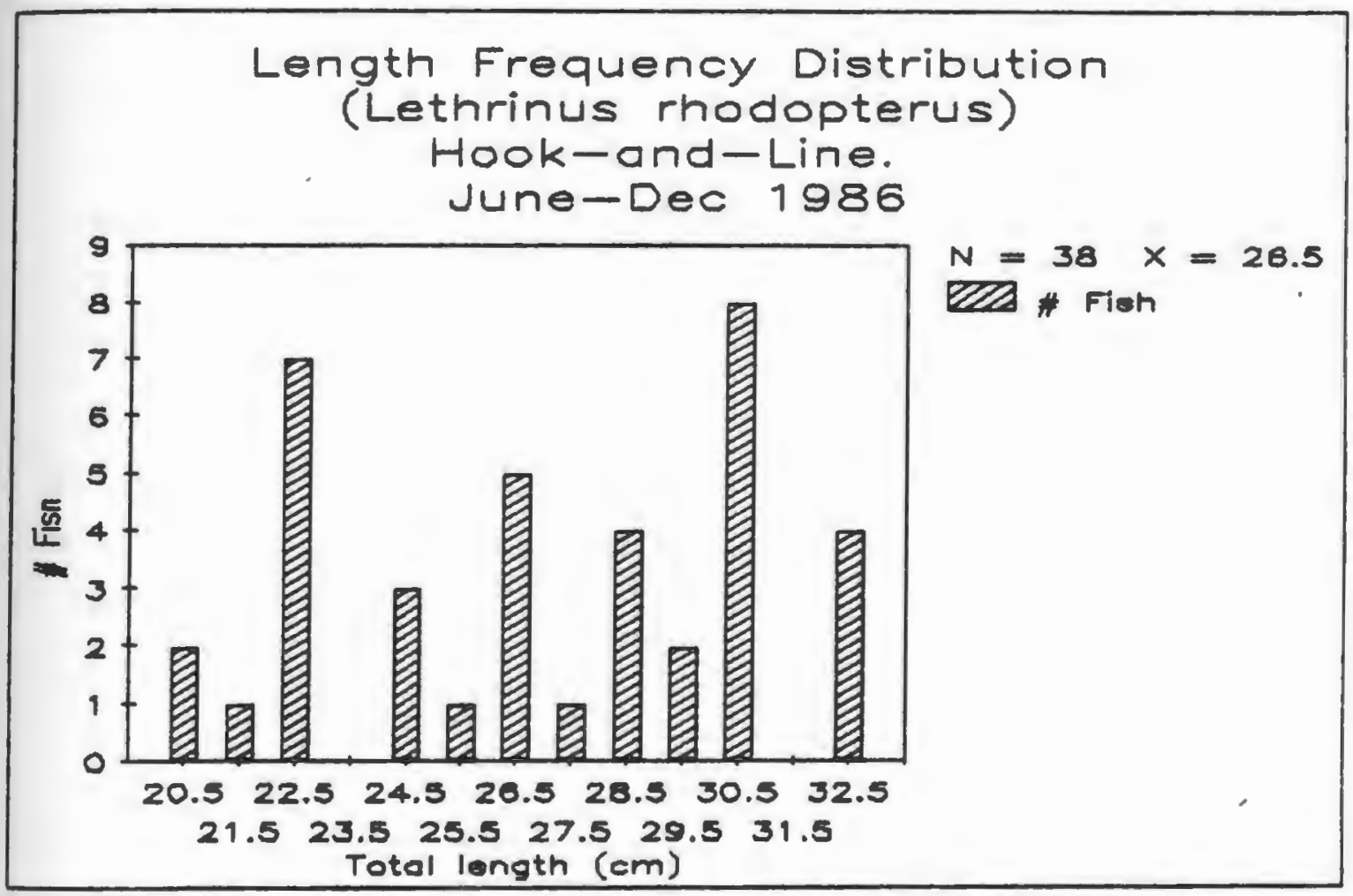




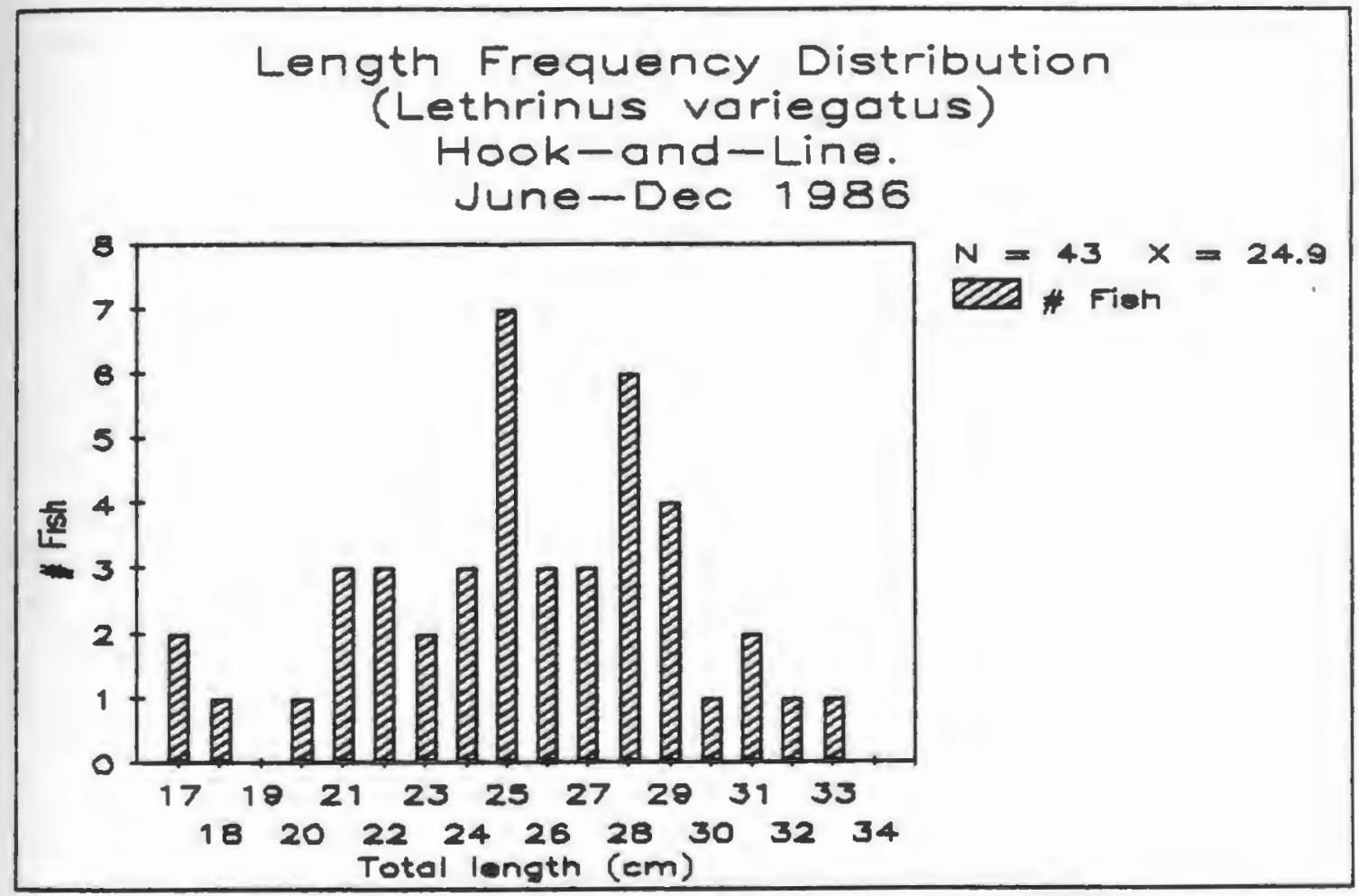




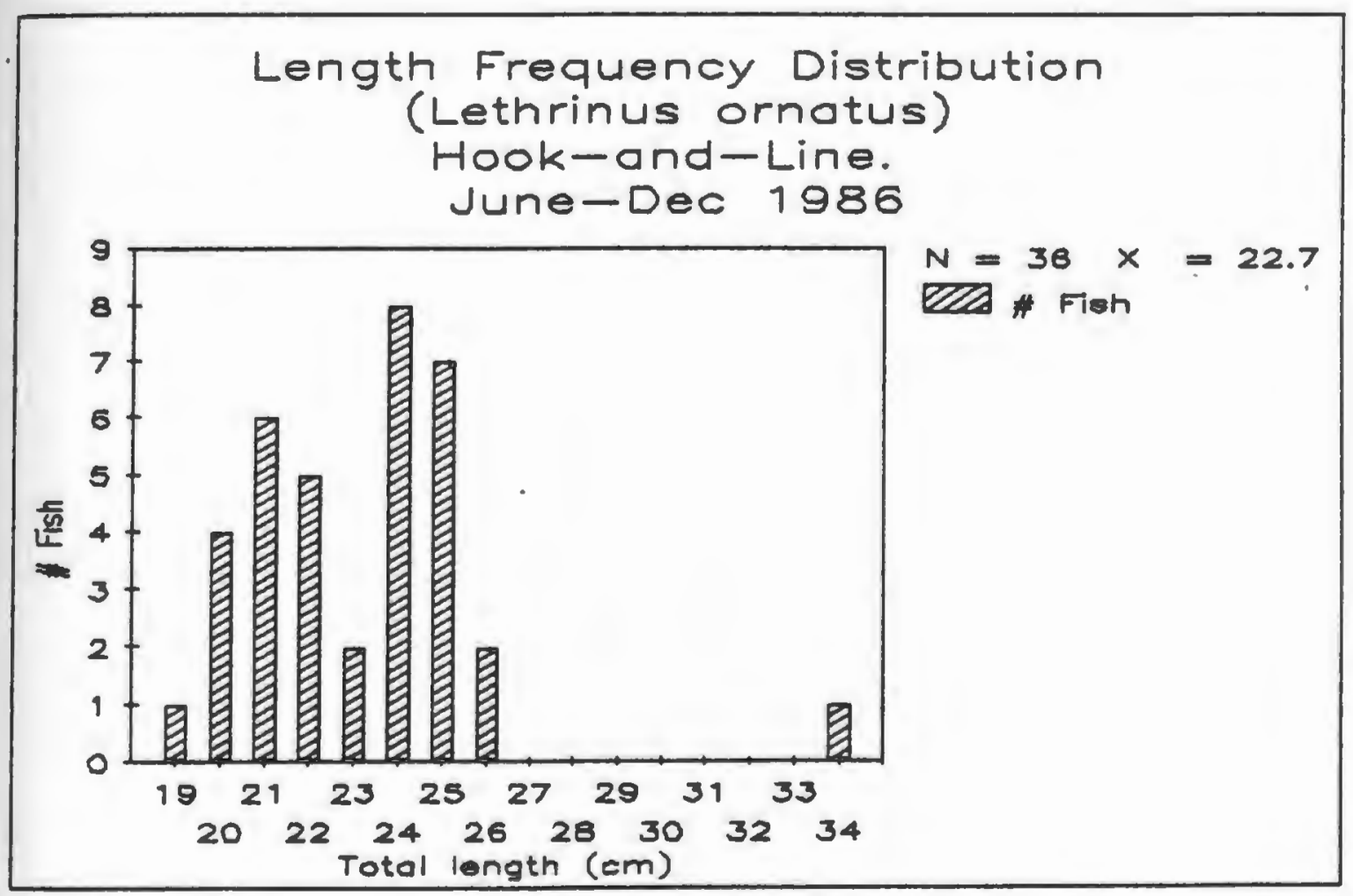




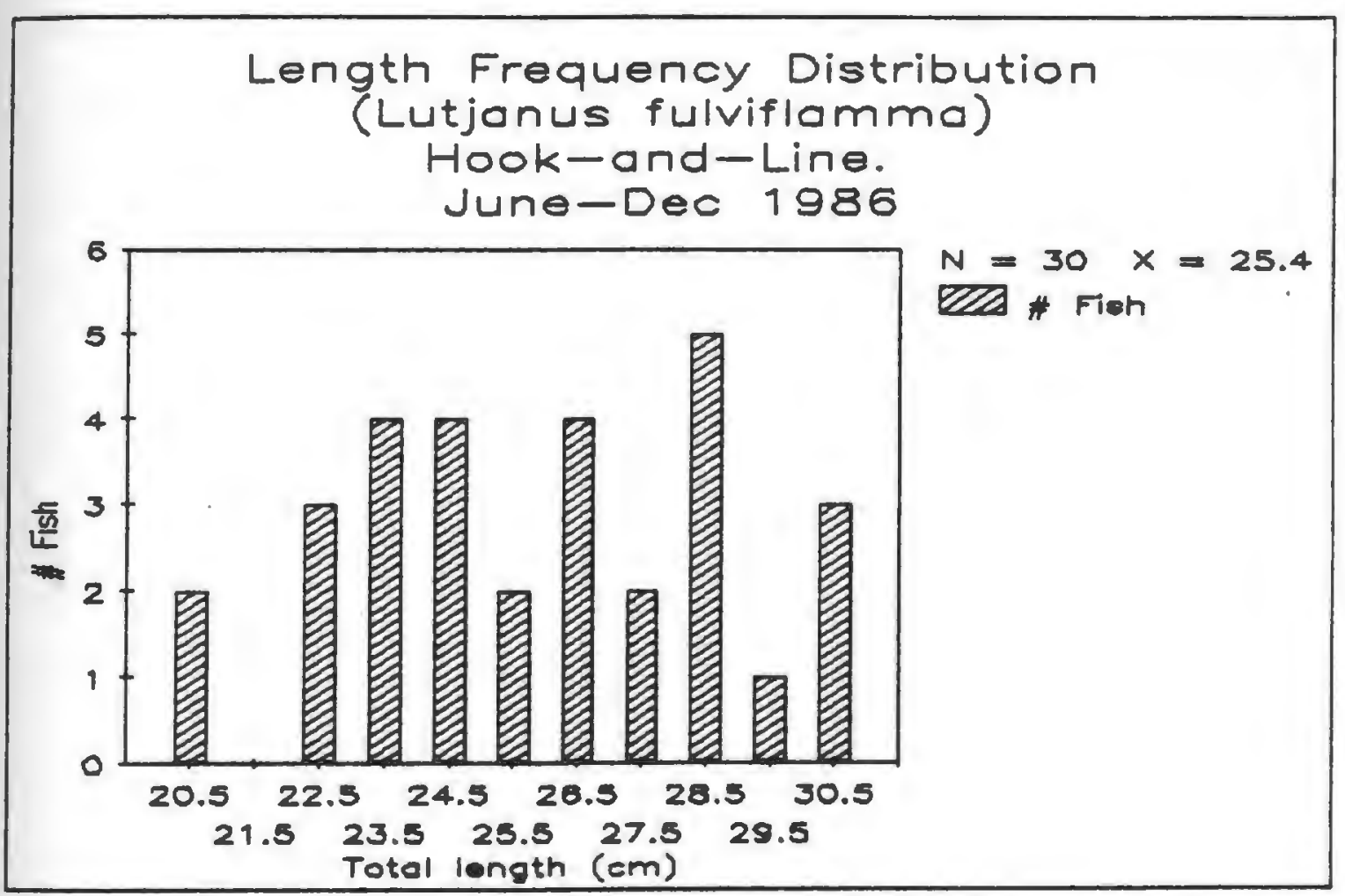




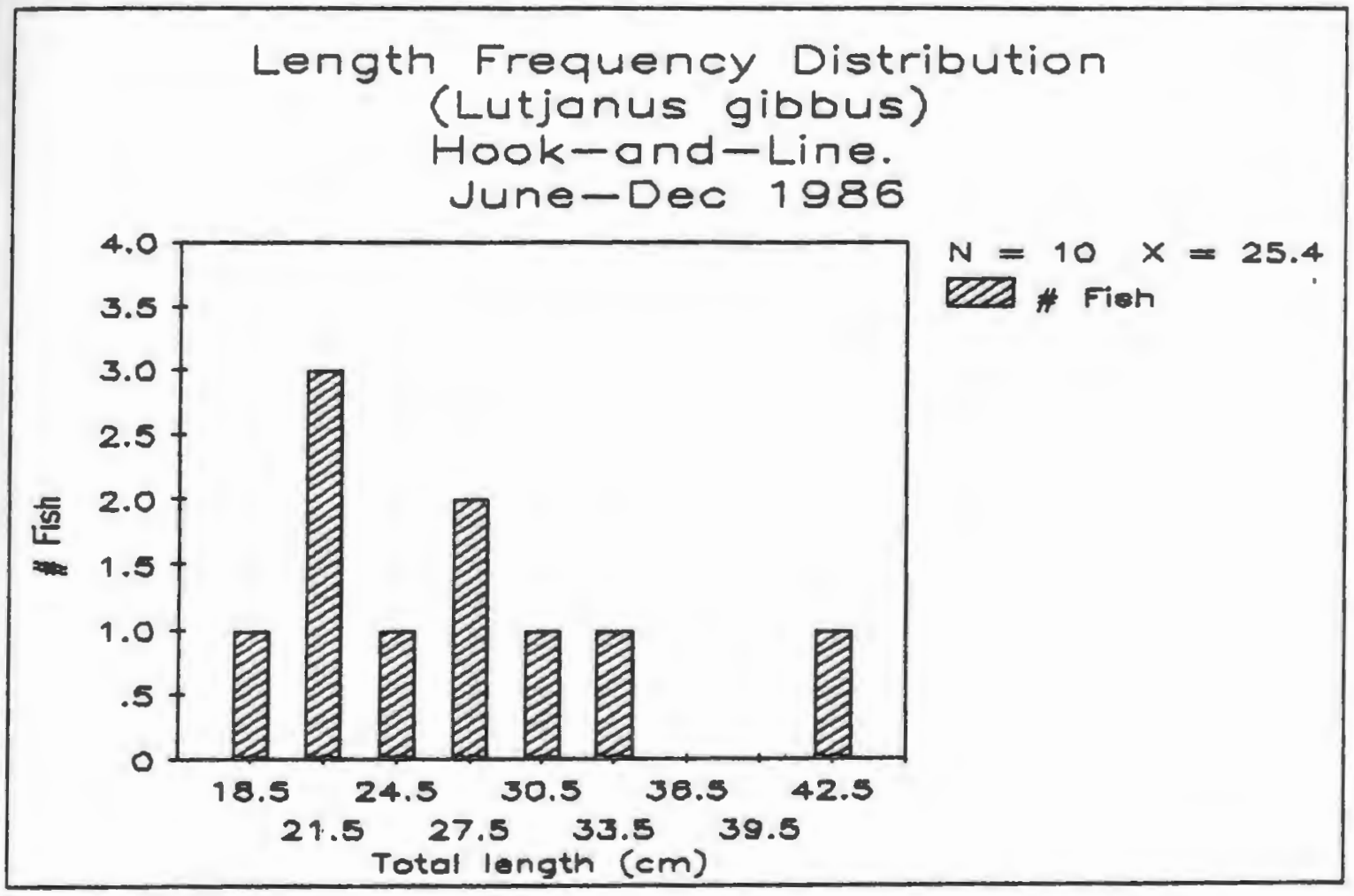


APPENDIX 10

10A. Length-weight relationship for Lethrinus rhodopterus caught by hook-and-line. JuneDecember 1986.

10B. Length-weight relationship for Lethrinus varaiegatuus caught by hook-and-line. JuneDecember 1986.

10C. Length-weight relationship for Lethrinus ornatulus caugth by hook-and-line. JuneDecember 1986.

10D. Length-weight relationship for Lutjanus fulviflamma caught by hook-and-line. JuneDecember 1986.

10E. Length-weight relationship for Lutjanus gibbus caught by hook-and-line. JuneDecember 1986. 


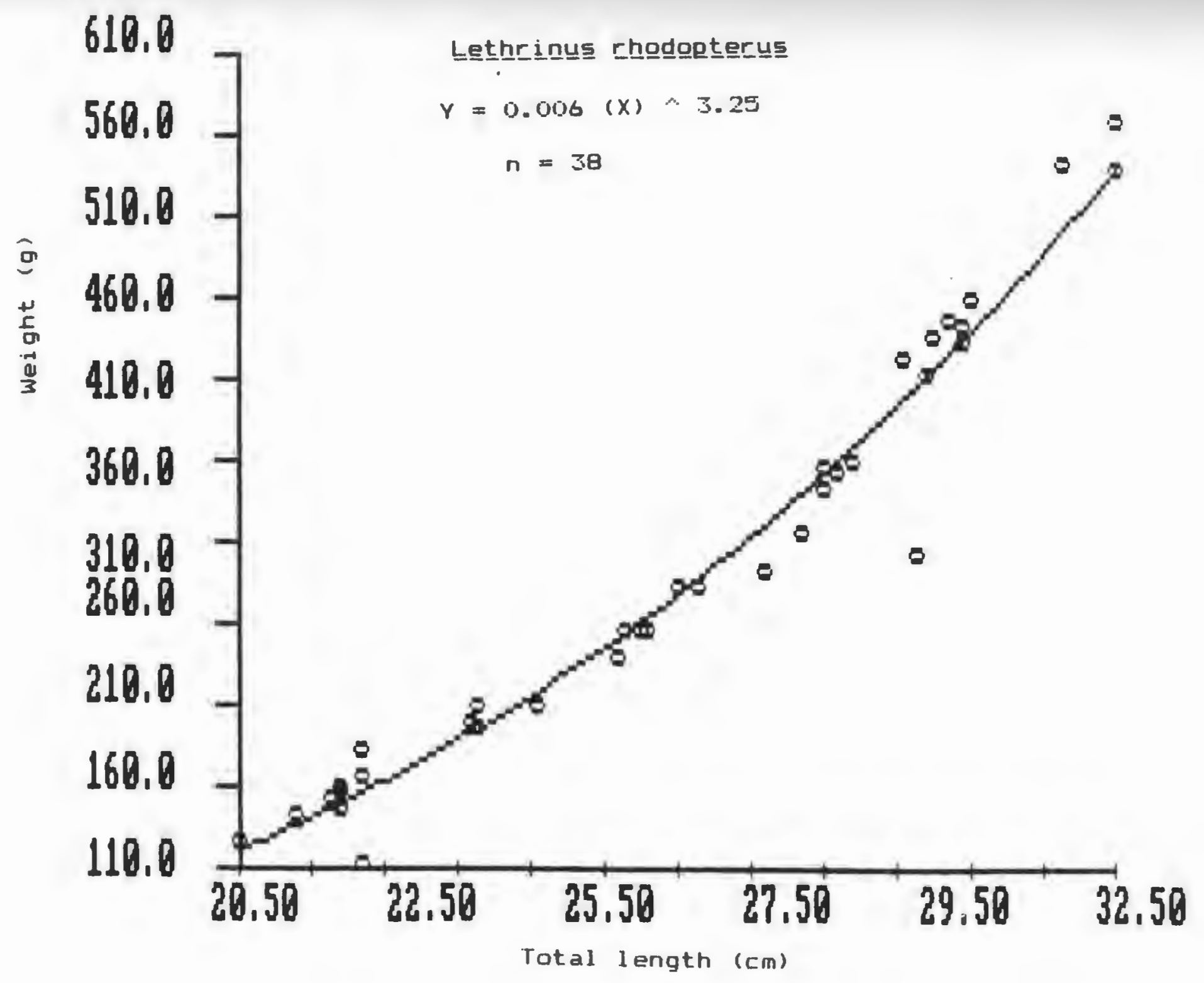




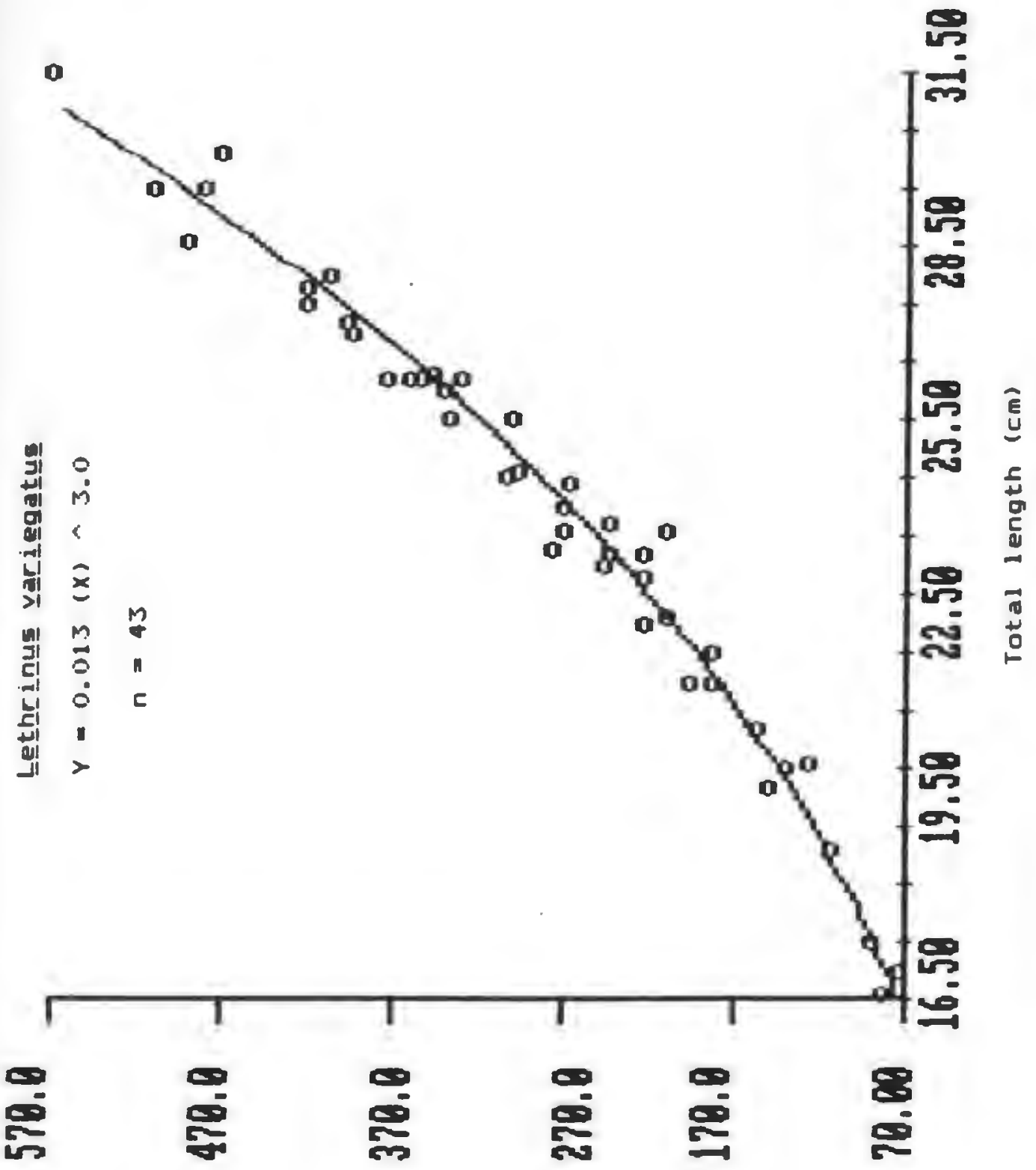

(6) 746 tam 


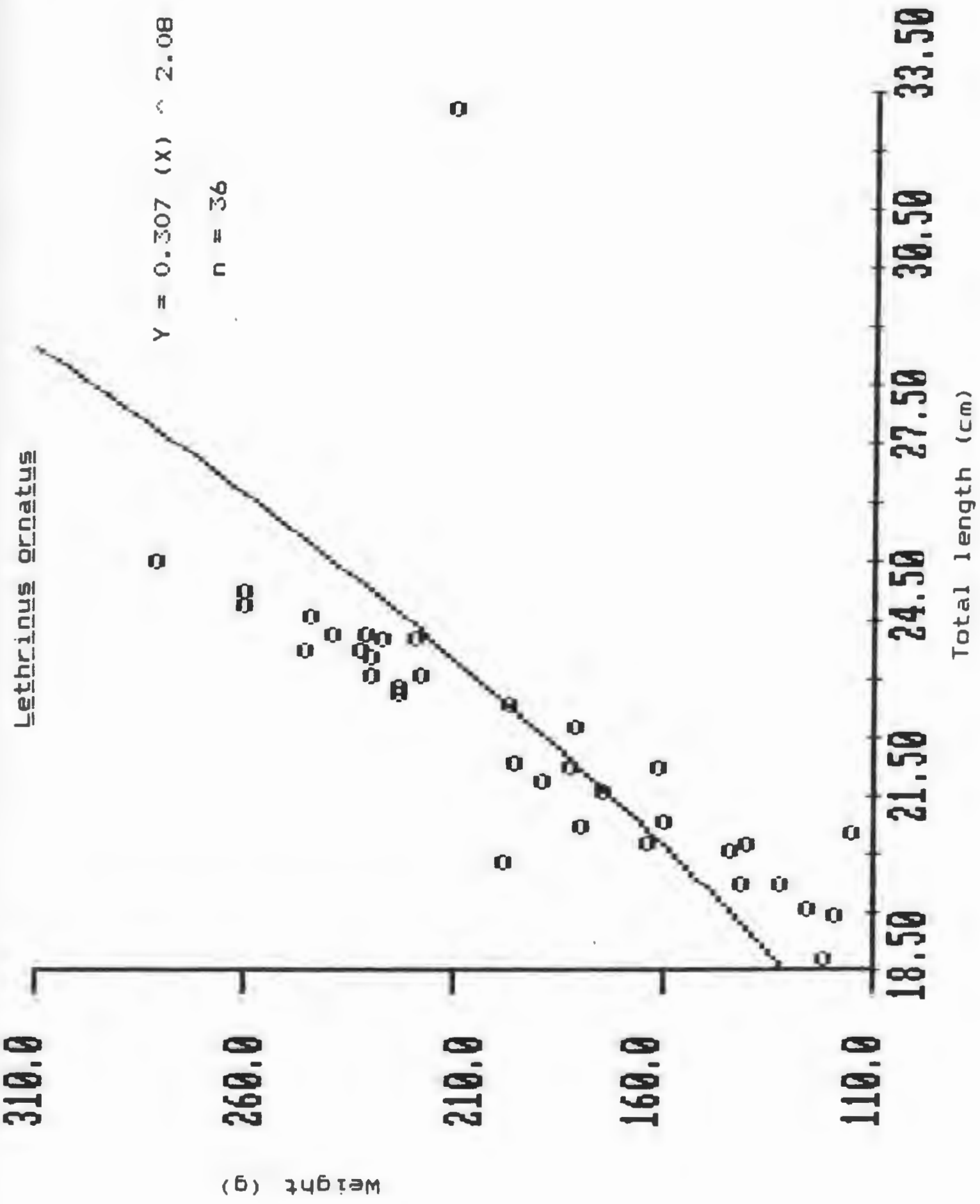




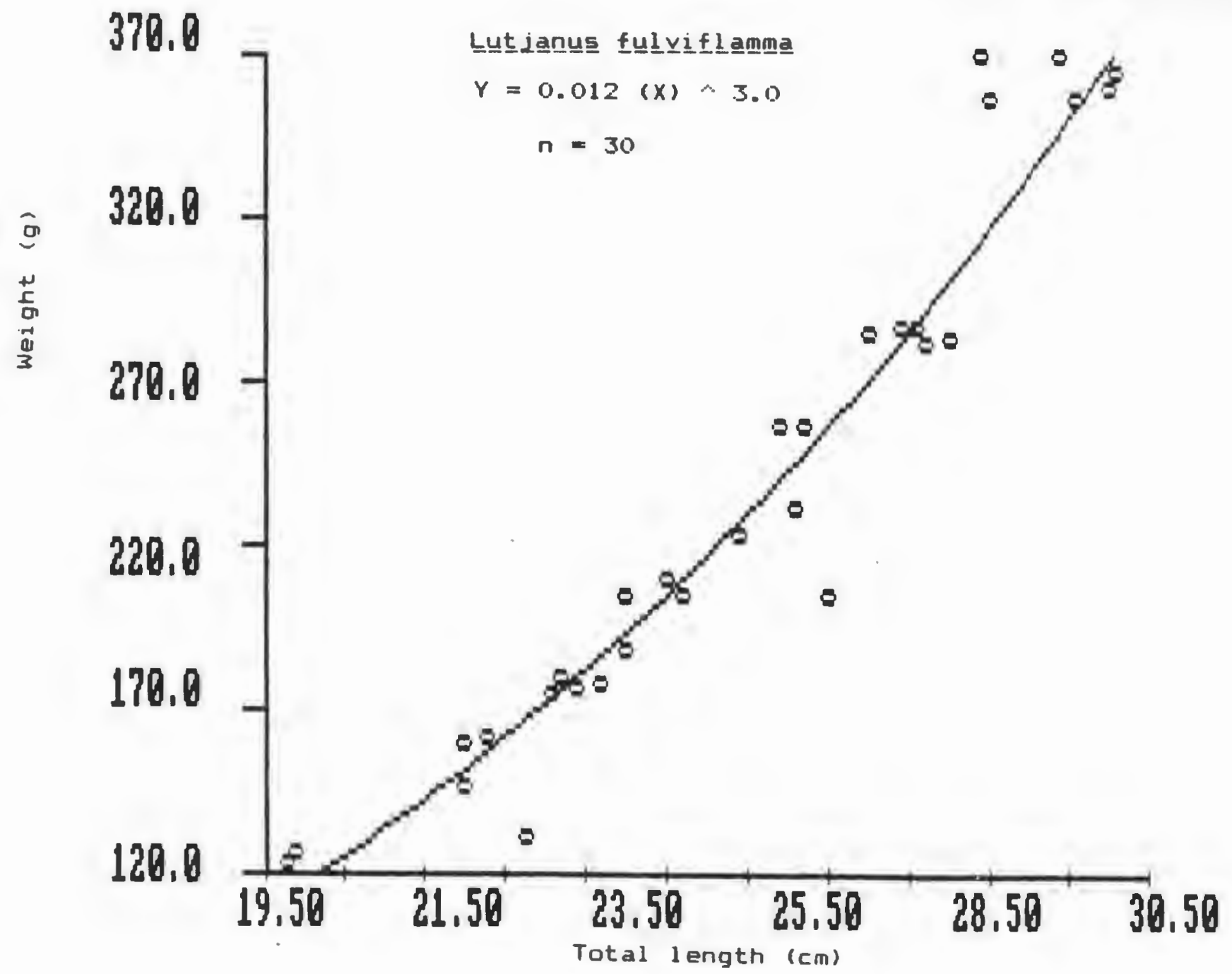




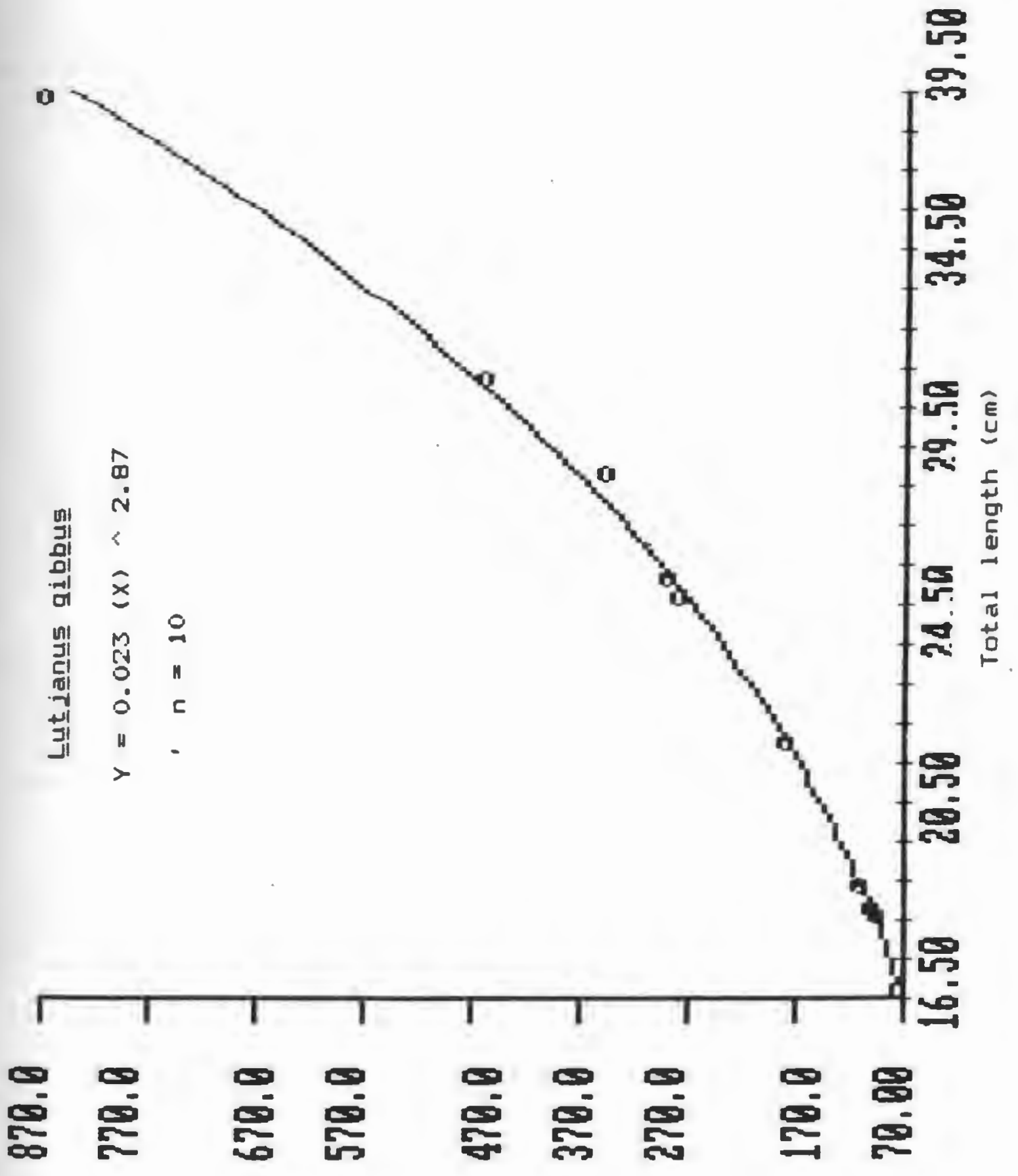

(5) 746 țam 
Appendix II

Species composition for the spear fishery Cape Bolinao.

Philipoines.

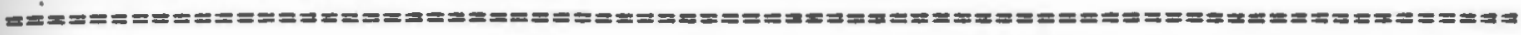

Family/Species

N $\quad \% N$

w $\%$ Ave.

5. D.

(g)

Length

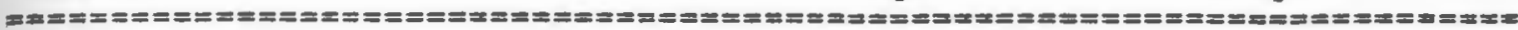

Gerridae

$\begin{array}{ccccccc}\text { Gerres macrosomo } & 12 & 0.56 & 201 & 0.21 & 11.6 & 0.93 \\ \text { Gerres sp. } & 1 & 0.05 & 52 & 0.06 & 16 & -0-0 \\ \text { Sub-total } & 1.3 & 0.61 & 253 & 0.27 & \end{array}$

Gobidae

Acentrogobiug puntang

Gnatholepis puntang 3

Ophiocara porocephala

Sub-total

43

0.19
1.7 .3
0.09
$-.0-$
2.01

112
972
65
-1149

0. 12

28
1.5

1. 0.3

32.5

1.3

0.07

1. 22

Hemi ramphidae

nemiramphus georgii ' 1

82

0.09

27.8

Labridae

Chaerodon anchorago 16

Cheilinus trilobatus 1

Ladrid a

1810
300

1. 92

0.32

0.05

0.05

0.05

0.07

Labrid e

0.09

68

0.49

0.05

Thal asoma hardwicke

\begin{tabular}{cr}
2 & 0.09 \\
--22 & 0.05 \\
\hline 22 & 1.03
\end{tabular}

0.10

$2774 \quad 2.85$

Sub-total

$0.14 \quad 107$

0.11

0.22

0.36

0.42

340

0.97

0.13

0.56
0.23

124

Lethrinus rhodopterus 12

$-0.23$

1697

$$
1.79
$$

16.8

2

Sub-total

33

1.54

Lut $j$ anidae

Lut janus

argenticulatus

Lut $j$ anus

fulviflama

$\begin{array}{ccr}1 & 0.05 & 415 \\ 9 & 0.42 & 553 \\ -10 & 0.47 & 968\end{array}$

0.44

29.4

Sub-total

10

0.47

968

0.59

15. 3

1.9

1.5

14.7

1.2

13.5

2. 1

1.9

11. 8

1.5

1. 03 
Mul 1 idae

Mulloidichthys

falvolineatus

Parapaneus barberinus 15

Parapaneus indicus 1

Upeneus moluccensis 2

Upeneus tragula

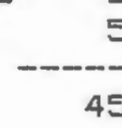

Sub-total

\begin{tabular}{l}
1.03 \\
0.70 \\
0.05 \\
0.09 \\
0.23 \\
\hline 2.11
\end{tabular}

$\begin{array}{r}1416 \\ 885 \\ 36 \\ 87 \\ 290 \\ \hline 2714\end{array}$

18.25

16.46

14.4

43.5

45.8

17.7

Pomacentridae

Stagastes sp.

10.05

5

13.7

Plotosidae

Plotosus I ineatus

Plotosus canius

Sub-total

$\begin{array}{cc}8 & 0.37 \\ 6 & 0.28 \\ -14 & -0.65\end{array}$

420
646
-1066

24.5

20

1.6

3

0.09

1.79

4.56

0.06

0.45

0.69

1.13

Scaridae

Leptoscarus

vaigensis

Scarus ghobban

0.61

0.14

867

0.92

0.22

Scarus $\mathrm{sp}$.

$\begin{array}{rr}13 & 0.61 \\ 3 & 0.14 \\ 16 & 0.75 \\ --- & -0.50\end{array}$

212

1.50

1421

Sub-total

$32-1.50$

2500

2.64

\section{Serranidae}

Epinephalus hoedtii 110.05

Epinephalus malucatus $1 \quad 0.05$

Epinephalus macrospilus 1

0.05

Epinephalus merra

17

0.80

Epineptalus summana

0.19

Sub-total

$\frac{4}{24} \quad-\frac{0.19}{1.12}$

\begin{tabular}{rr}
88 & 0.09 \\
47 & 0.05 \\
700 & 0.74 \\
834 & 0.89 \\
229 & 0.24 \\
\hline 1898 & -2.01
\end{tabular}

16.1

1.8

15.9

17

0.6

3.6

Siganidae

Siganus

canal iculatus

Siganus guttatus

siganus spinus

1872

25

1

Sub-total

1896

87.65
1.08
0.05
$-.0-0$.

77233.6
1469.4
170
--78979

82.00

1.56

0.18

14.5

14.3

21.4

88.77

78875

83.74

Sillaginidae

Sillago gracilis

10.05

162

0.17

26.5

Ter aponidae

Fielates quadrili

0.05

19

0.02

10.1 
APPENDIX 12

12A. Length-frequency distribution for Siganus guttatus caught by spear, June-December 1986.

12B. Length-frequency distribution for Gnatholepis puntang caught by spear, June-December 1986 .

12C Length-frequency distribution for Mulloidichthhys

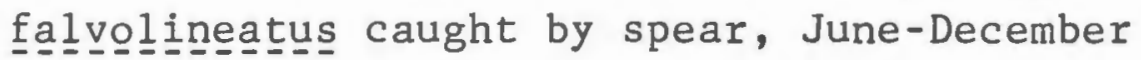
1986. 


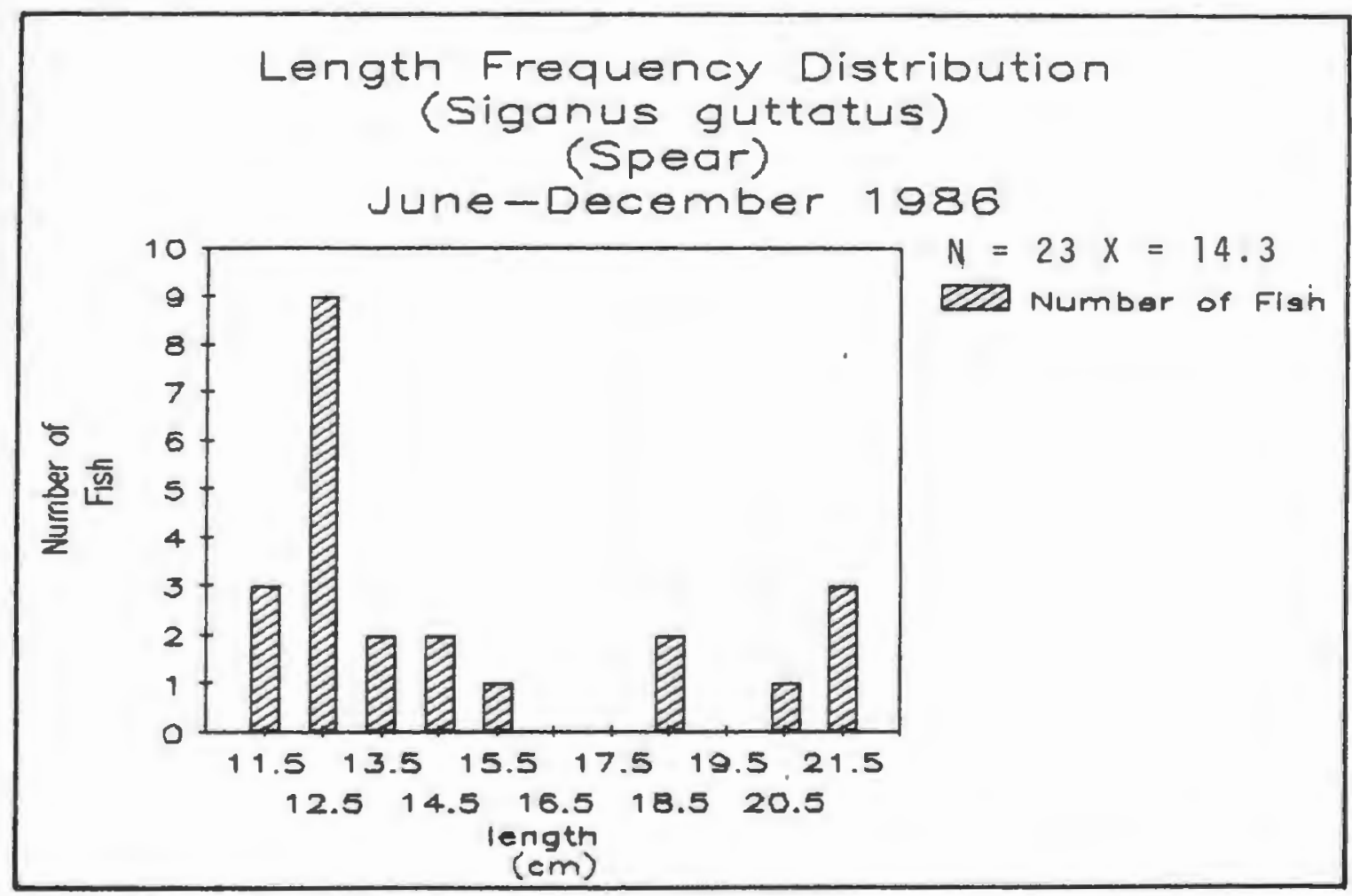




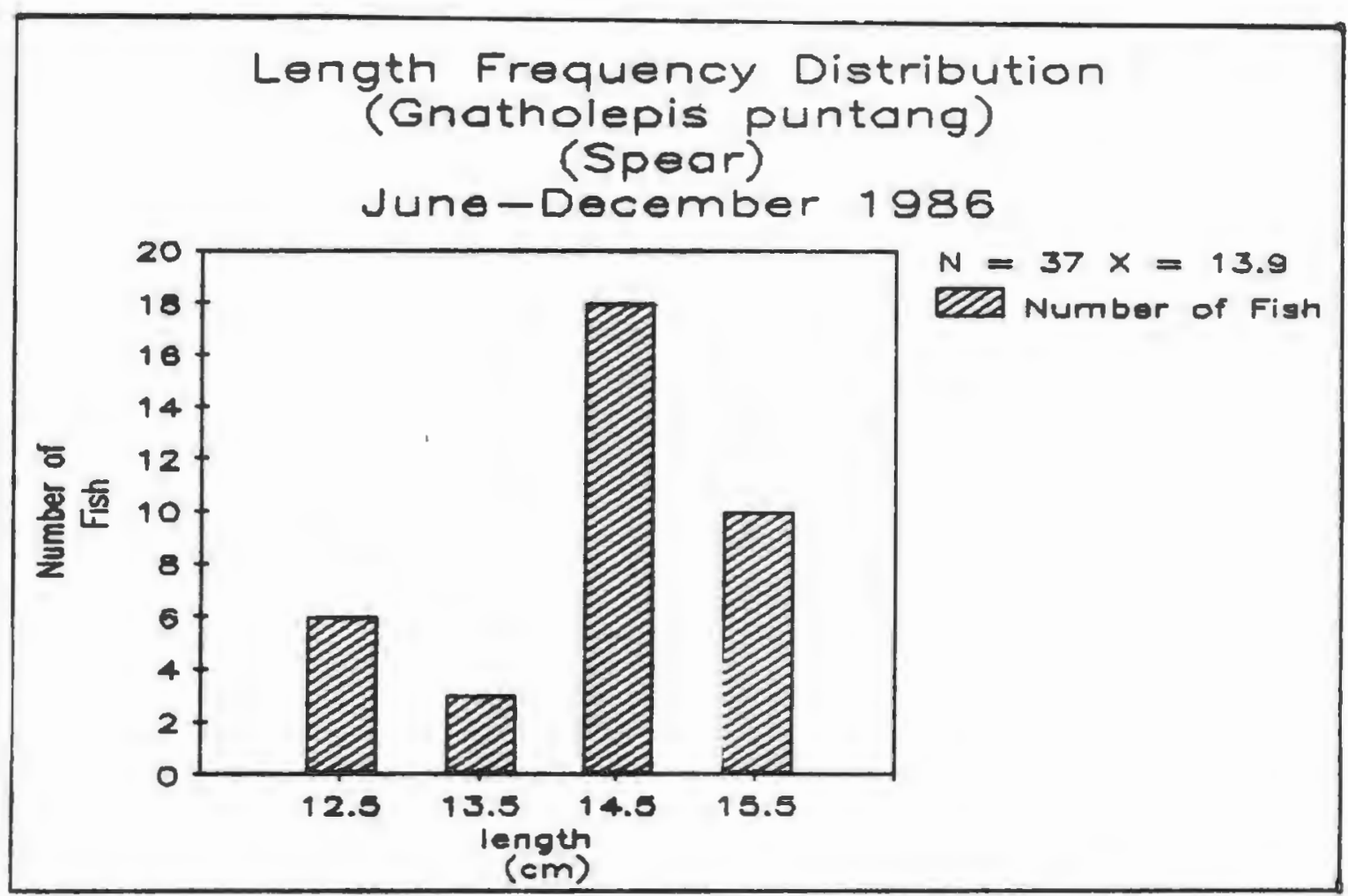




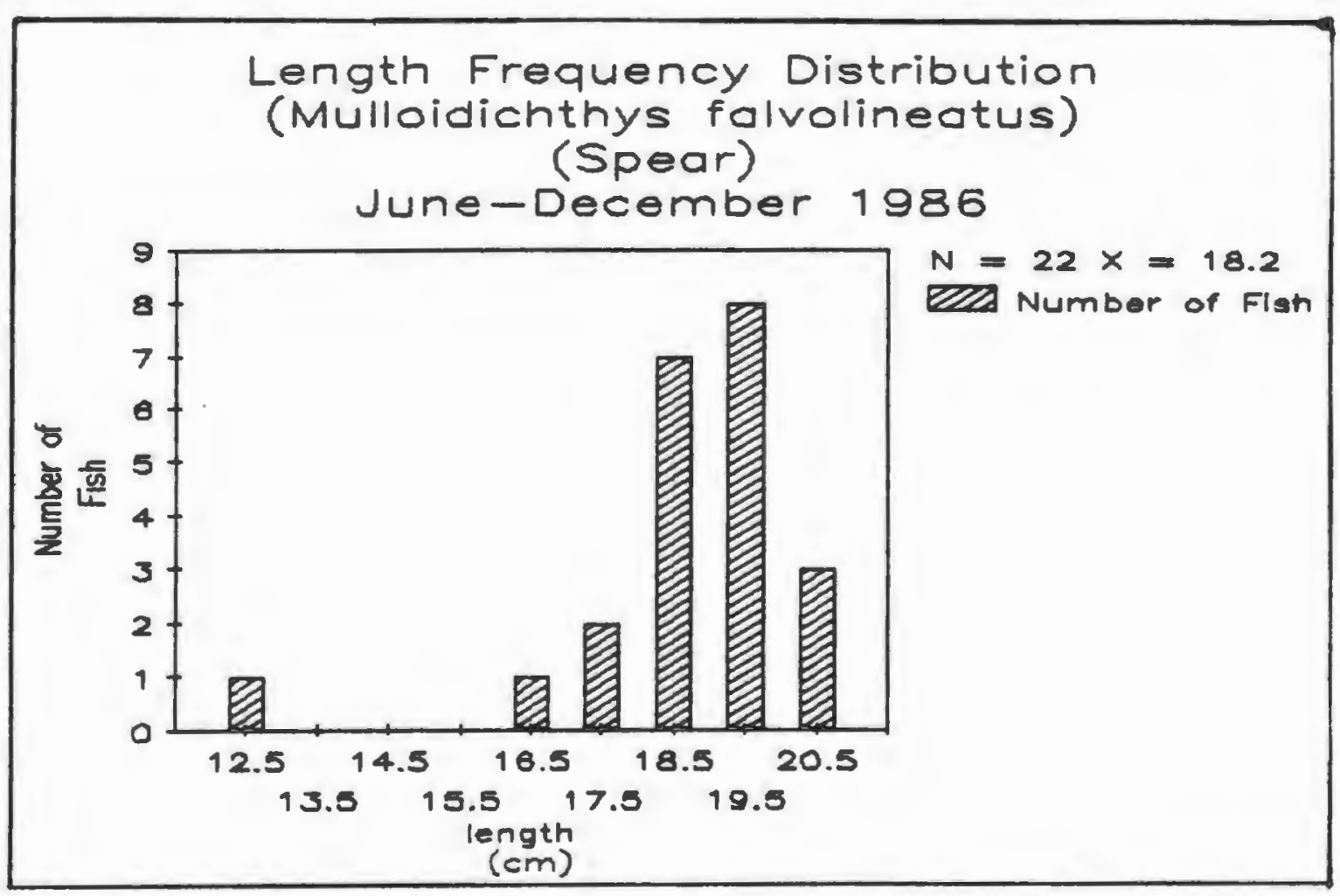


APPENDIX 13

13A. Length-weight relationship for Siganus gutttatus caught by spear. June-December 1986 .

13B. Length-weight relationship for Gnatholepis puntang caught by spear. June-December 1986.

13C. Length-weight relationship for Mulloidichthys falvolineatus caught by spear. June-December 1986. 


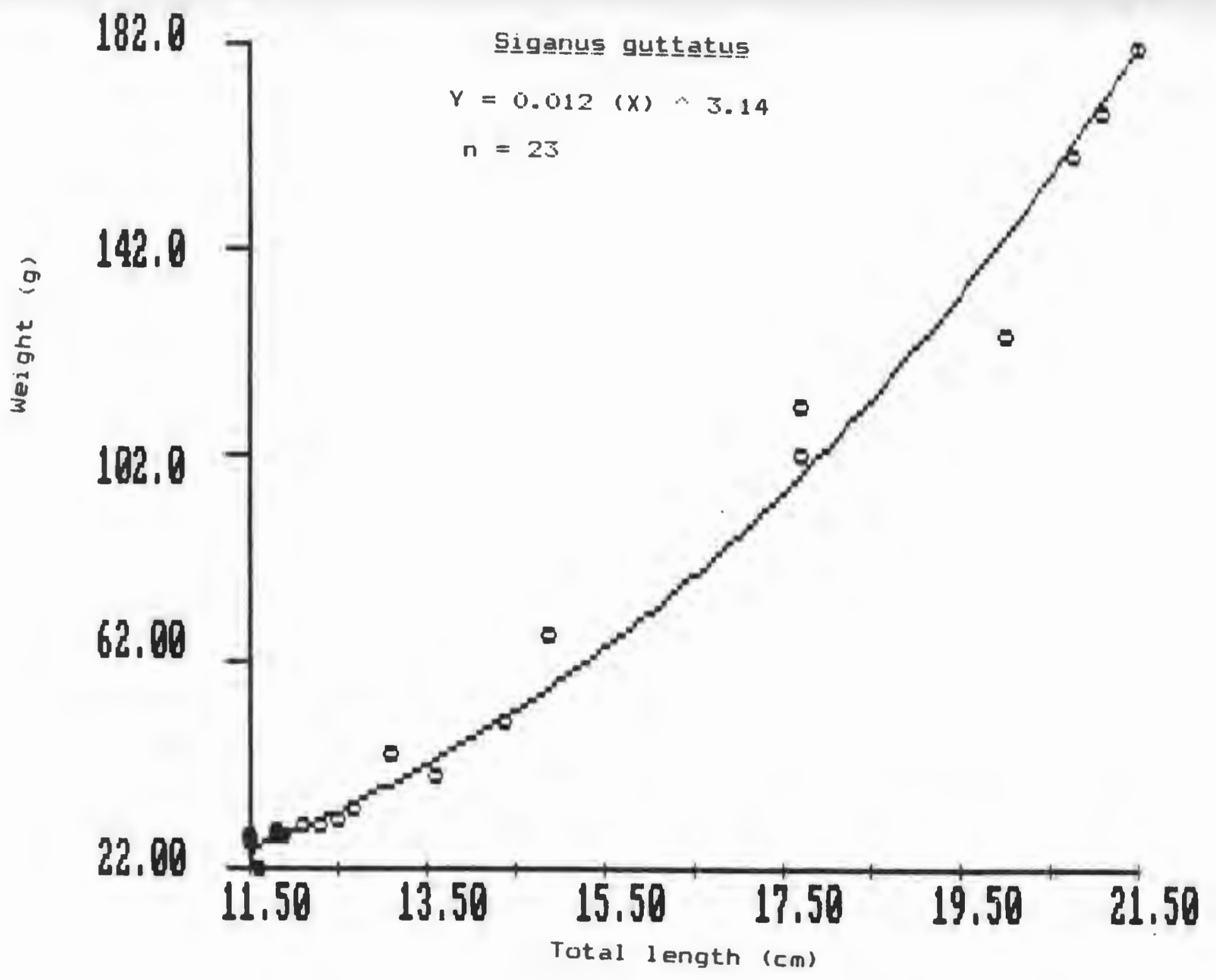


Gna

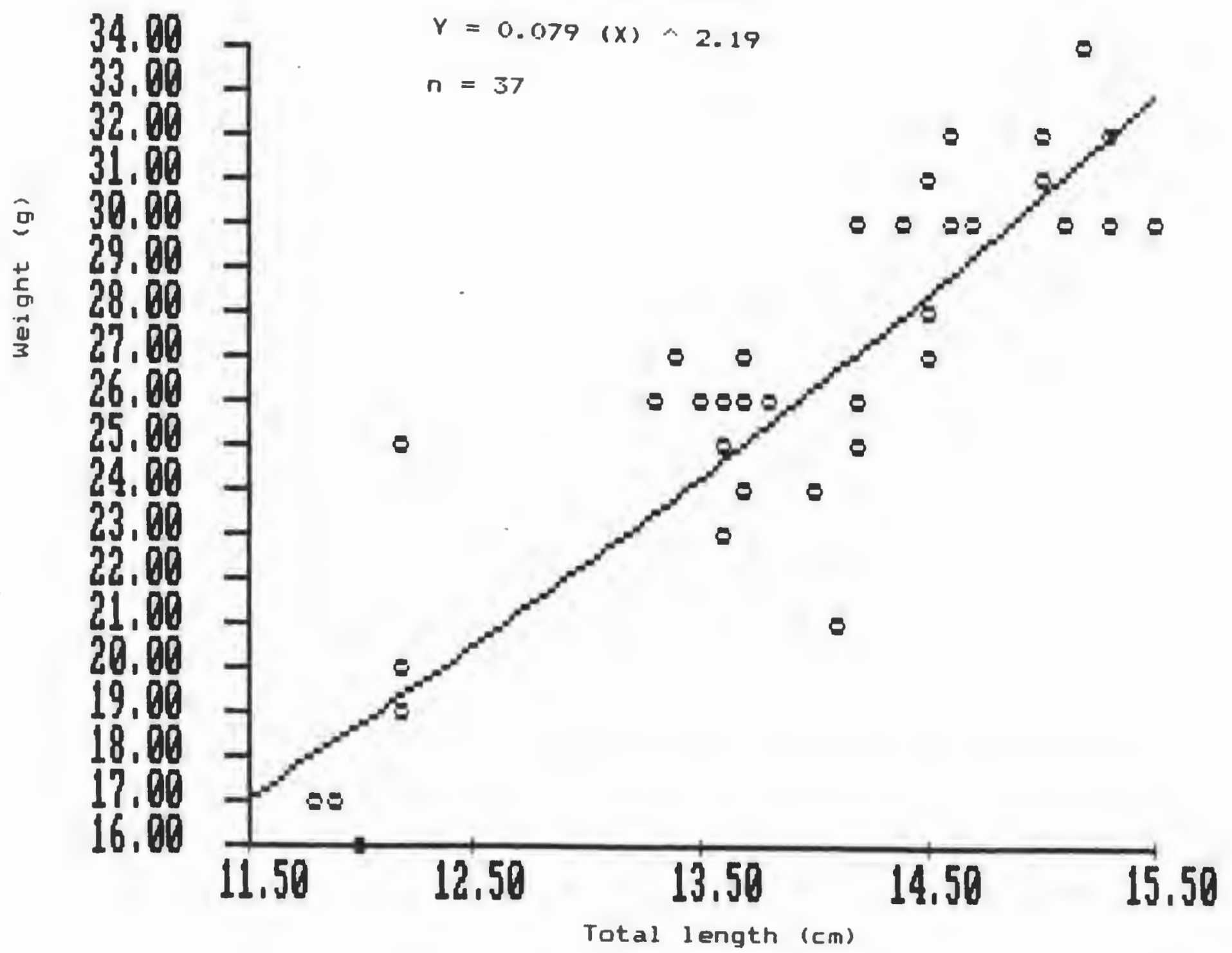




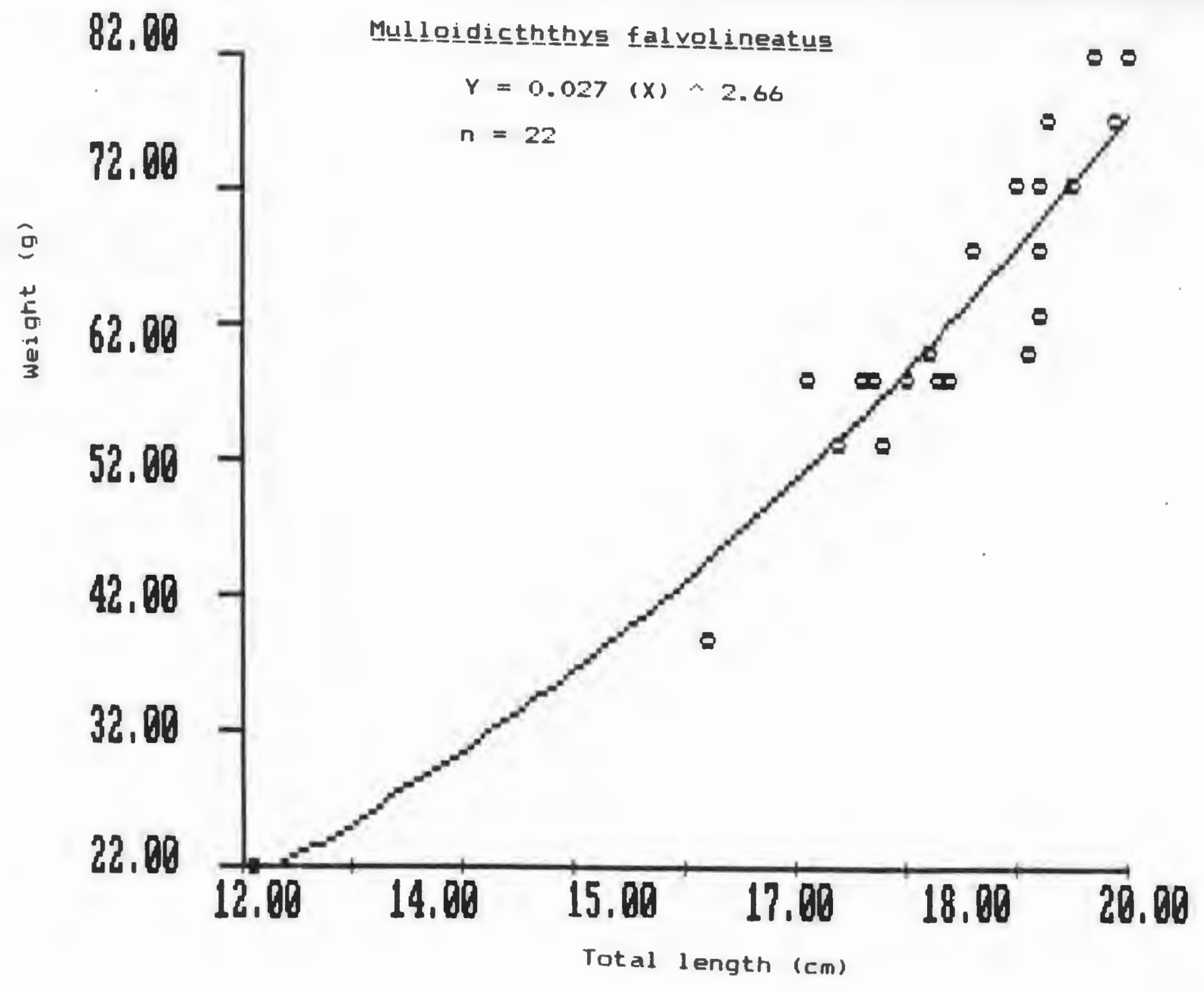


APPENDIX 14

14. Monthly length-frequency distribution for Siganus canaliculatus caugth by spear JuneDecember 1986. 


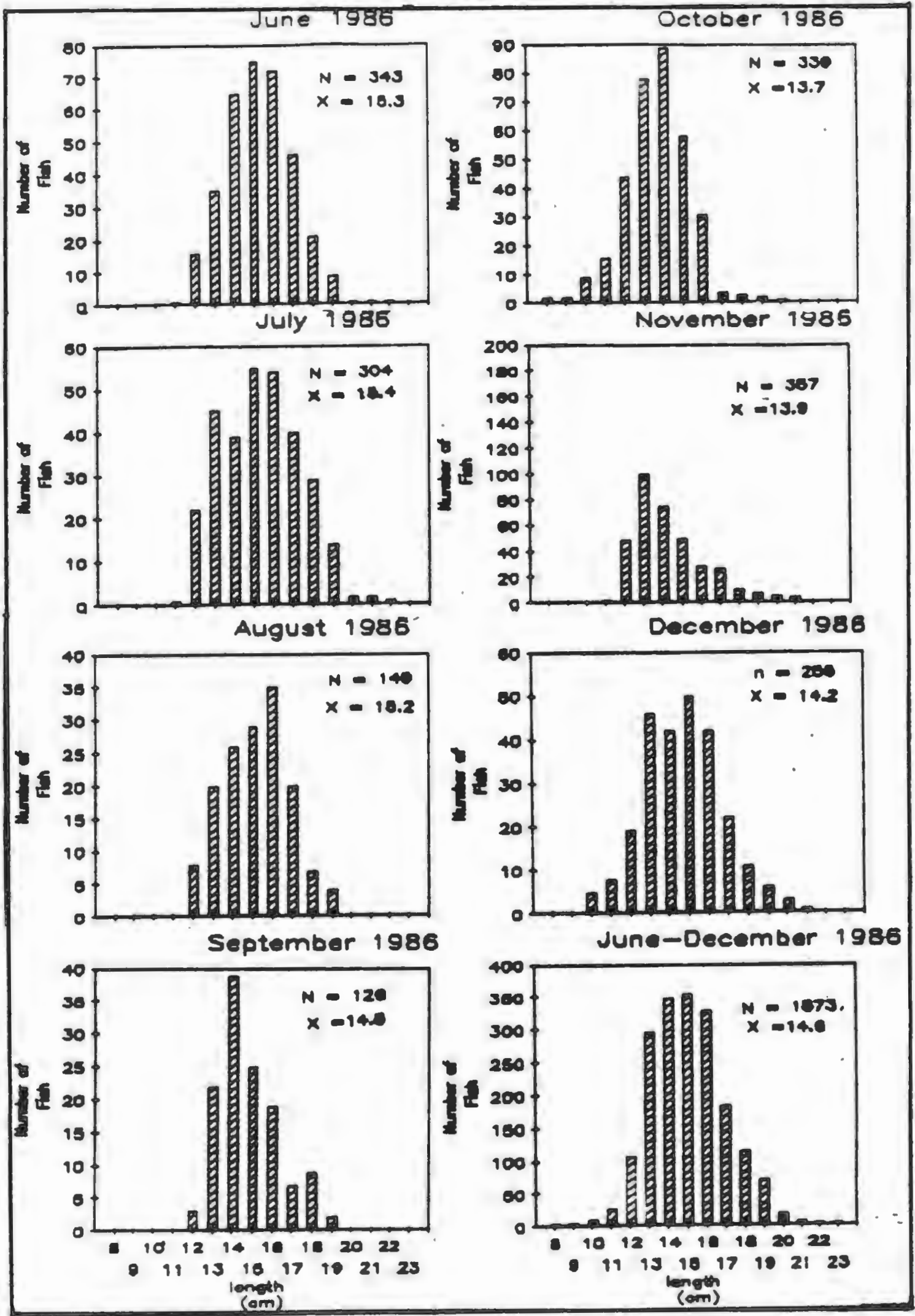


APPENDIX 15

15A. Length-weight relationship for Siganus canaliculatus caught by spear, Jüne-1986.

15B. Length-weight relationship for Siganus canaliculatus caught by spear JüIy-I986.

15C. Length-weight relationship for Siganus canaliculatus caught by spear, Āugūs $\bar{t}-1986$.

15D. Length-weight relationship for Siganus canaliculatus caught by spear, Sēpeēmber 1986.

15E. Length-weight relationship for Siganus canaliculatus caught by spear, October 1986.

15F. Length-weight relationship for Siganus canaliculatus caught by spear, November 1986.

15G. Length-weight relationship for Siganus canaliculatus caught by spear, December 1986.

15H. Length-weight relationship for Siganus

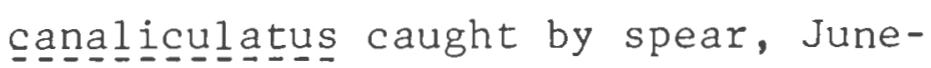
December 1986. 


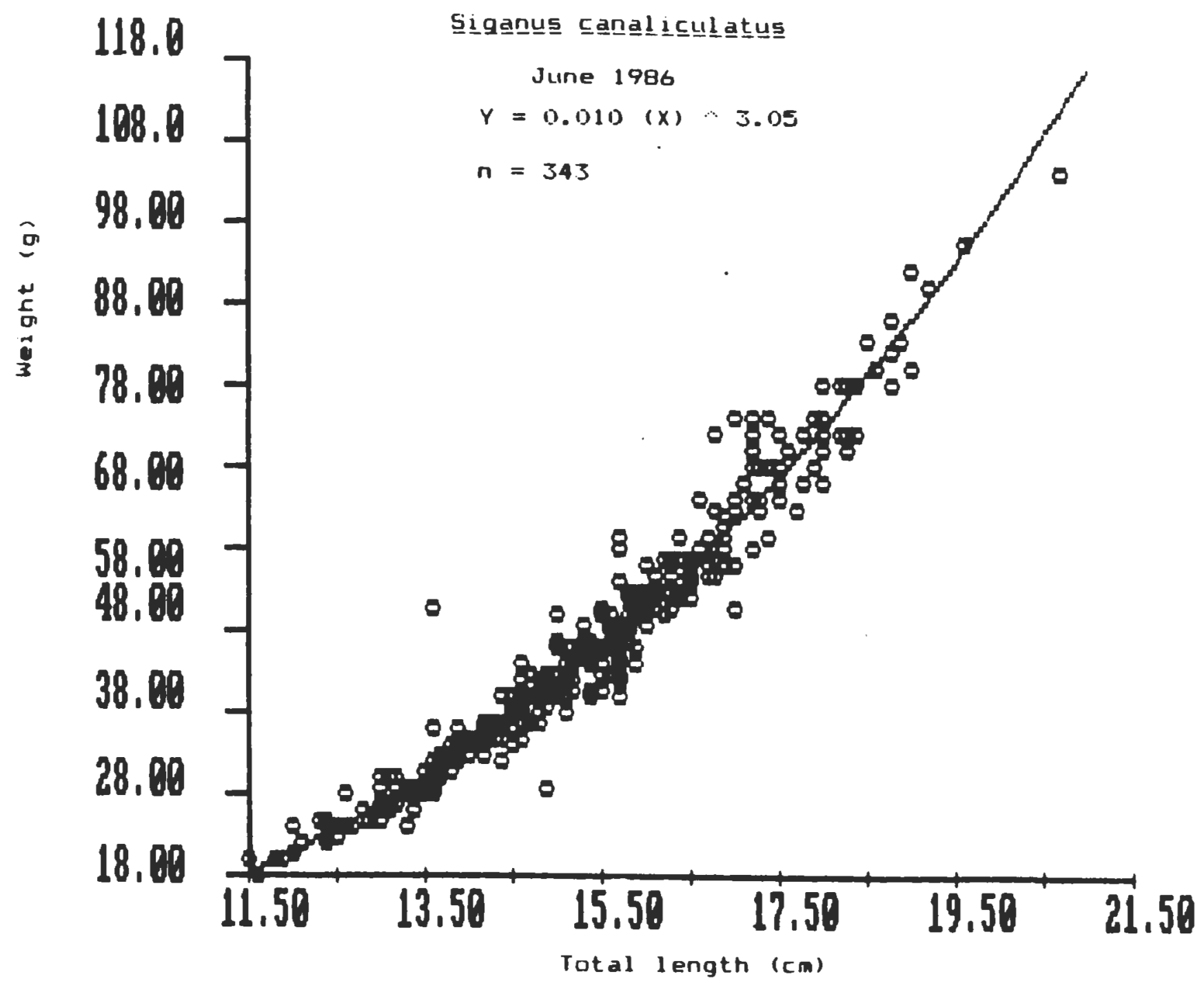




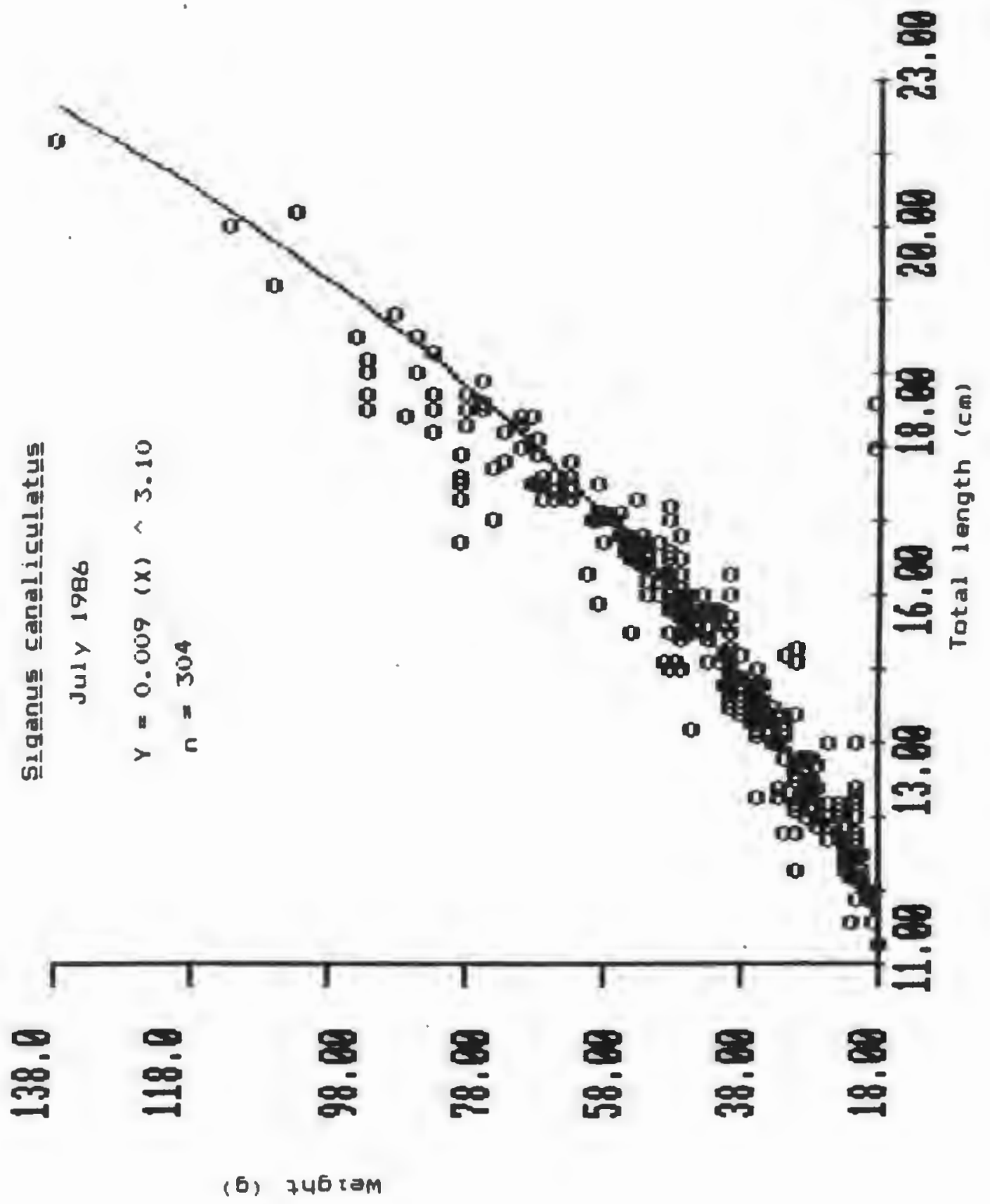




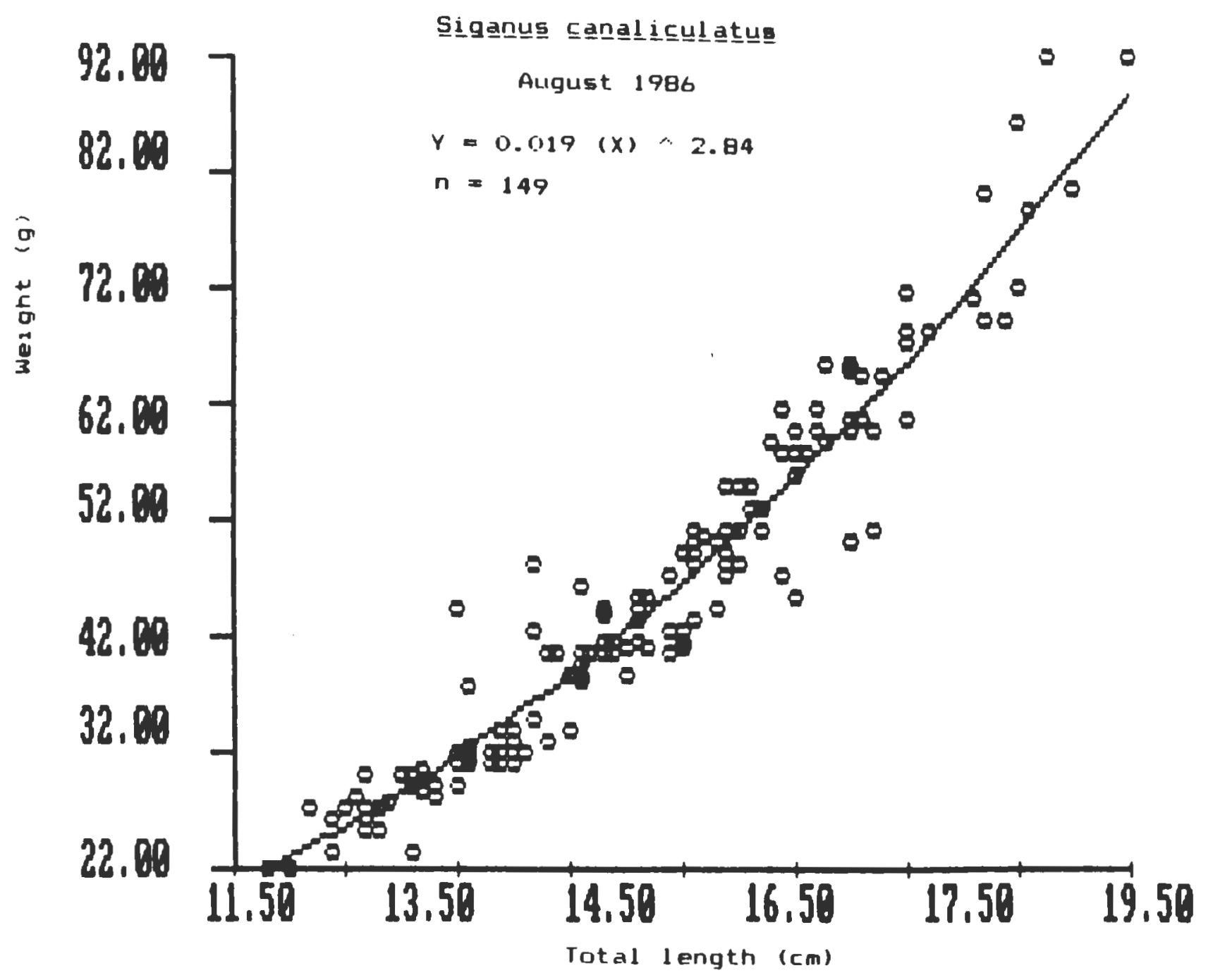




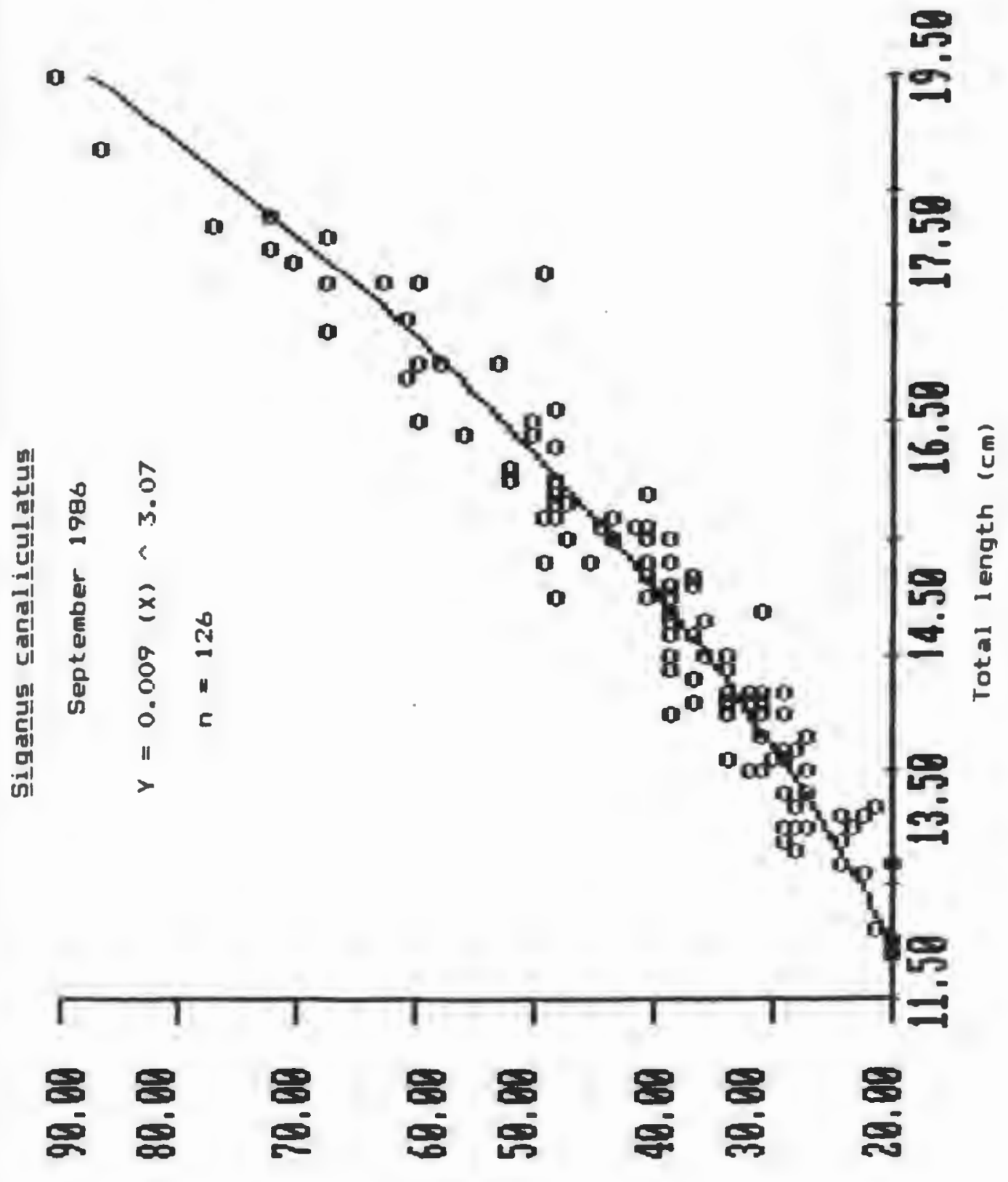

(6) $746 \mathrm{ram}$ 


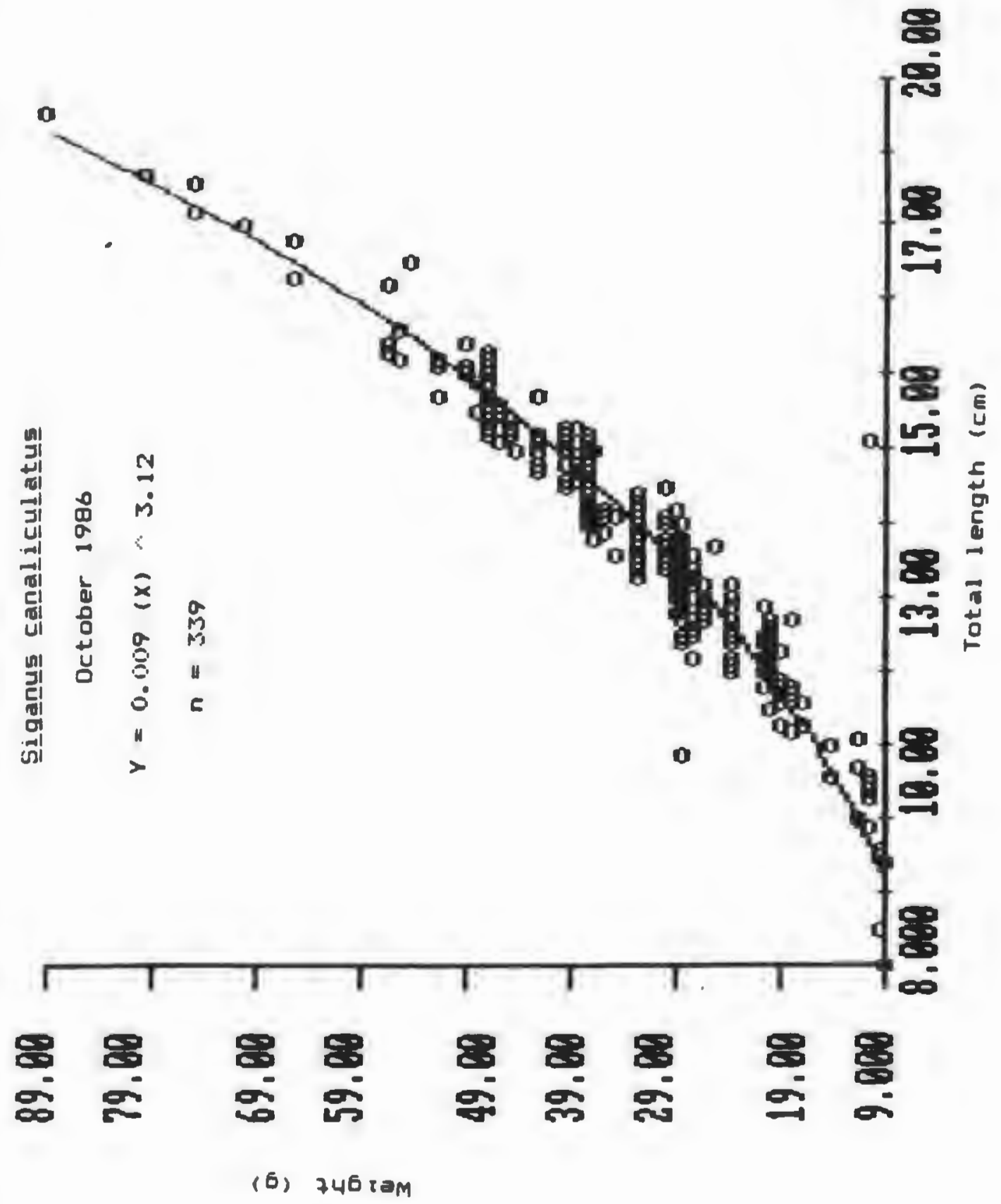




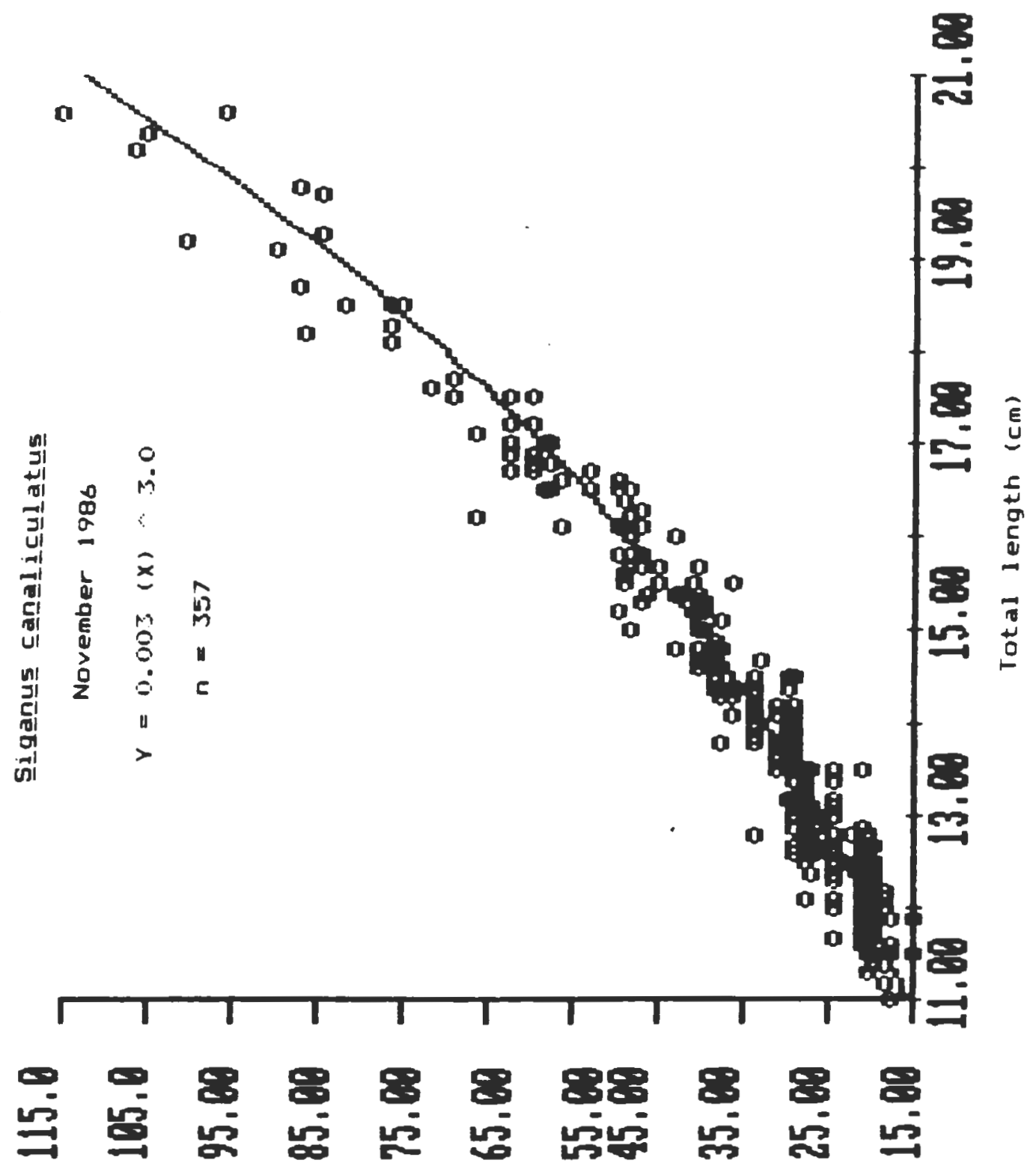

(b) $746 \mathrm{tam}$ 


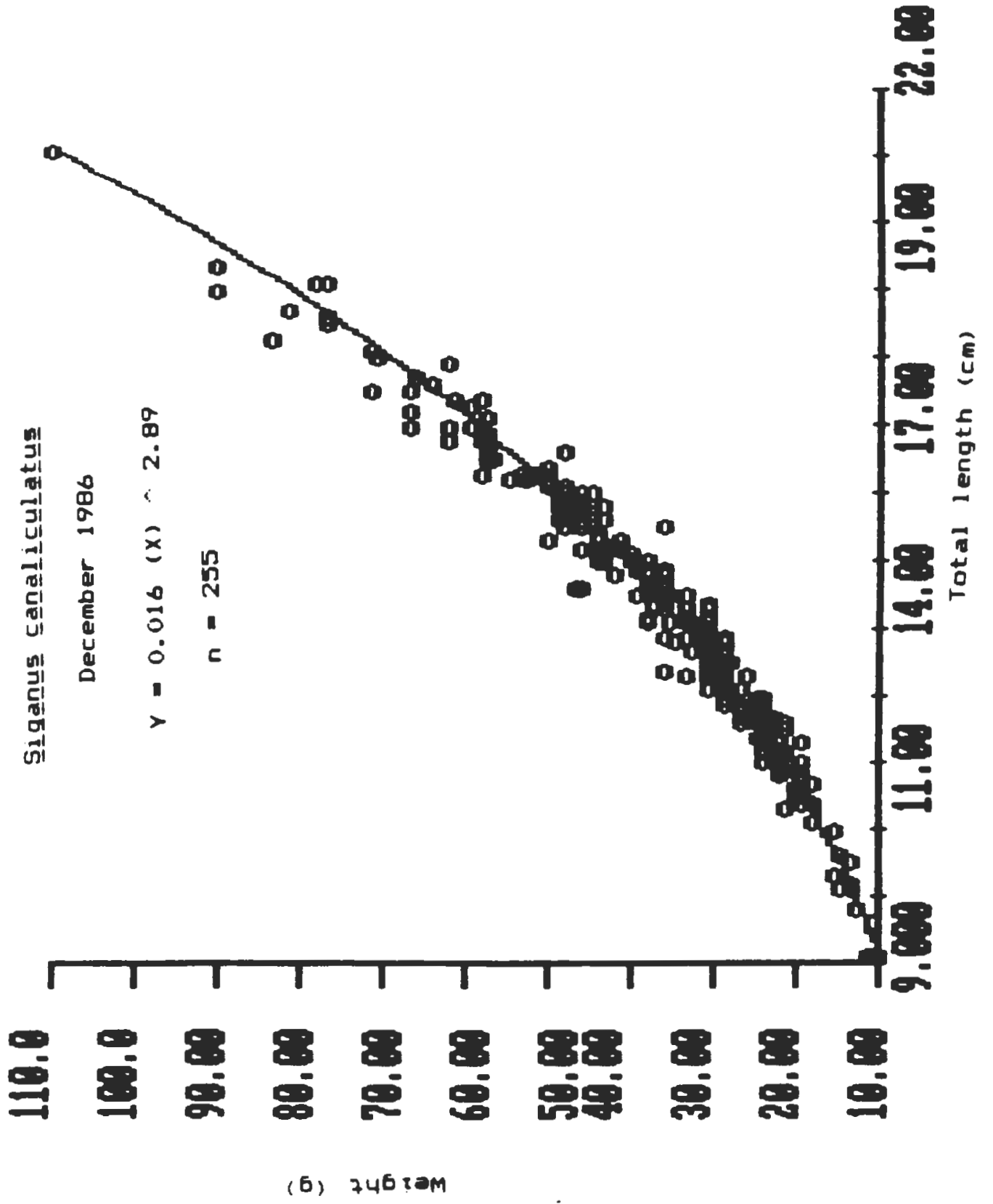




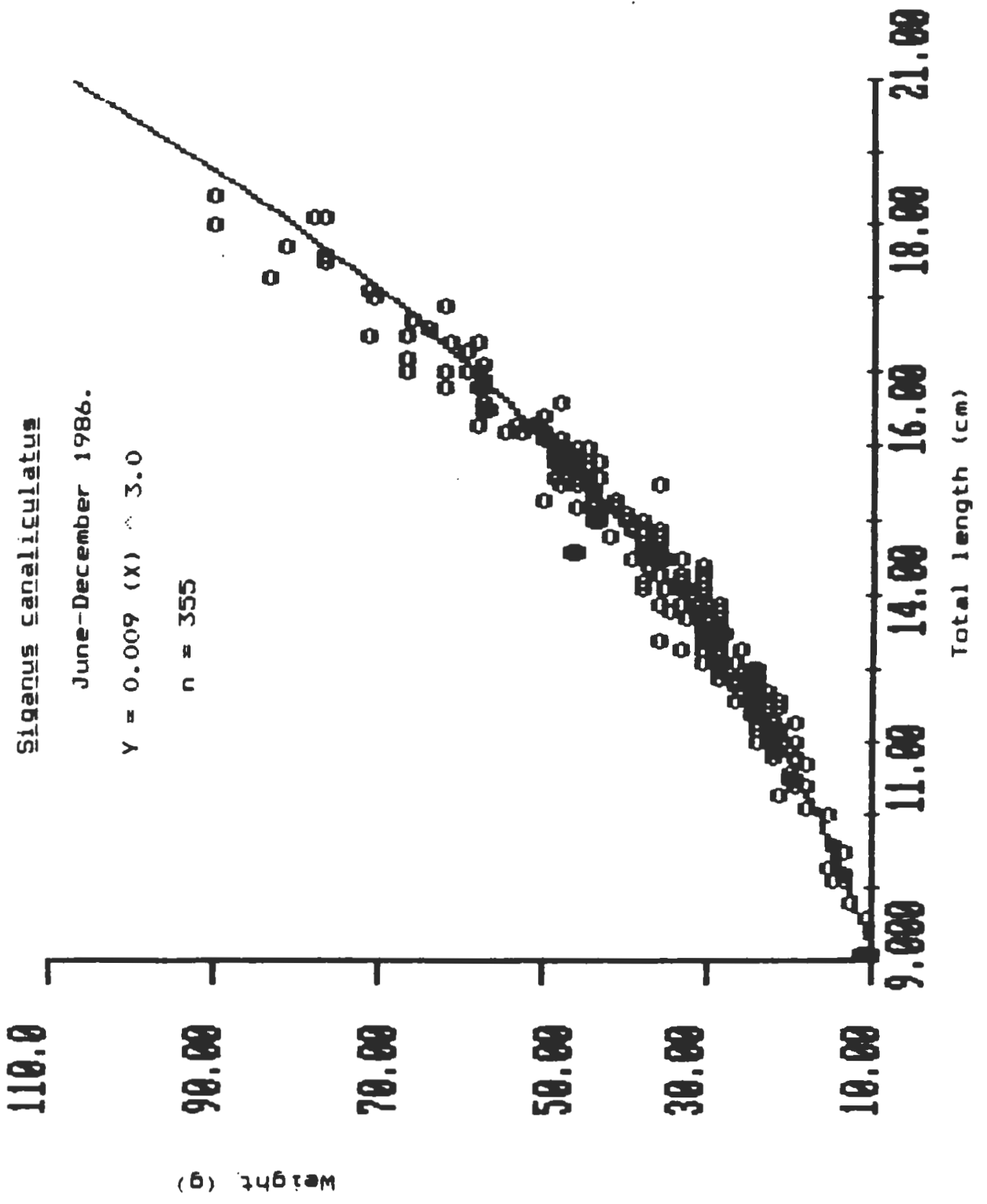

